[1the

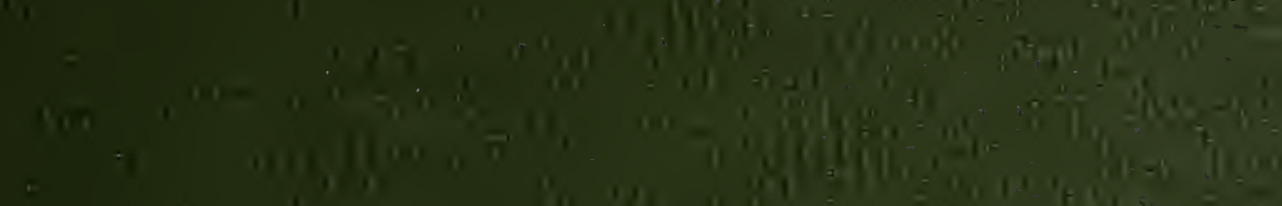

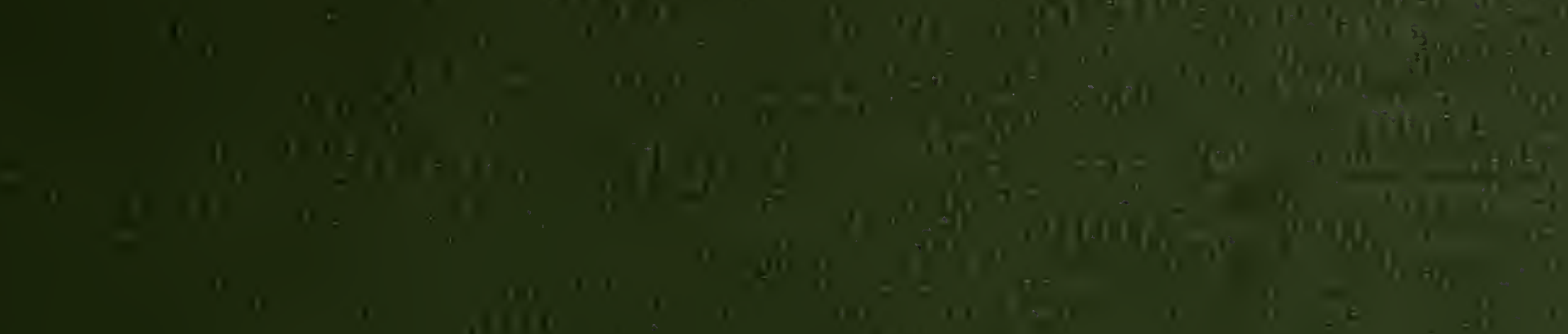
+ 





Real Academia de Bellas Artes de San Fernando.

ศ్

REJEROS ESPAÑOLES

(ENSAYO ARTISTICO-ARQUEOLÓGICO)

- POR -

D. EMILIO ORDUÑA Y VIGUERA

OBRA PREMIADA EN EL CONCURSO DE 1910

EN CUMPLIMIENTO DEL LEGADO INSTITUIDO POR EL

EXCMO. SR. MARQUES PE GUAPALERZAS

ILUSTRADA CON 42 LAMINAS

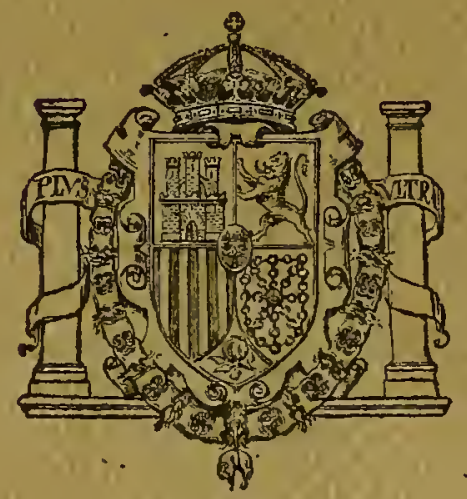

MADRID

IMPRENTA DE SAN FRANCISCO DE SALES

Calle de la Bola, núm. 8.

$1 \overline{15}$ 


\section{REJEROS ESPAÑOLES}



Real Academia de Bellas Artes de San Fernando.

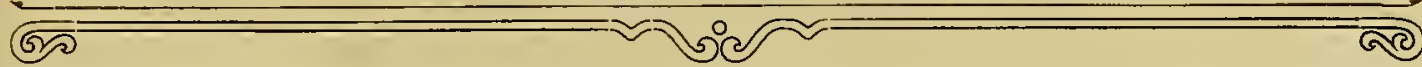

\section{REJEROS ESPAÑOLES \\ - P O R -}

\section{EMILIO ORDUÑA Y VIGUERA}

(ENSAYO ARTÍSTICO-ARQUEOLÓGICO)

OBRA PREMIADA EN EL CONCURSO DE 1910

EN CUMPLIMIENTO DEL LEGADO INSTITUídO POR EL

EXCMO. SR. MARQUES PE GUAPALERZAS

Y PUBLICADA CON FONDOS DEL MISMO

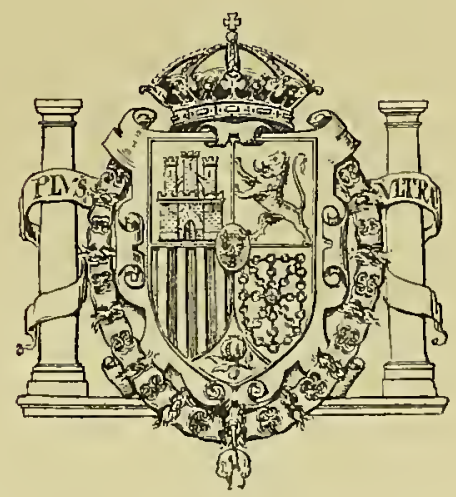

MADRID

IMPRENTA DE SAN FRANCISCO DE SALES

Calle de la Bola, núm. 8 .

1915 
Esta obra es propiedad de la Real Academia de Bellas Artes de San Fernando.

Pily 1960
Gift

\section{4}




\section{IITRODUCCIÓN}

Es tan extensa la industria del hierro, que nuestro objeto ha de limitarse tan sólo a la parte referente a la Rejería y Cerrajería, aun cuando se reconozca su dependencia con otras secciones y artes similares de la misma industria.

- Preciso es comencemos por ocuparnos del tecnicismo y valor de algunas palabras usadas corrientemente en un sentido, que en realidad no es el propio en que deben aceptarse, olvidando en cambio las más genuínas.

Tal acontece con los Rejeros, así llamados en la Edad Media y el Renacimiento a los constructores de aquellas artísticas y elegantes obras con que cerraban recintos o ventanas, mientras hoy vemos sustituido aquel nombre por el de Cerrajeros, limitando asi a una especialidad del trabajo lo que antes tenía una expresión más propia de la importante labor a que se dedicaban.

Otro tanto ocurre con la palabra Metalistería, que no consta en los Diccionarios consultados, cuya omisión no puede menos de causar sorpresa, toda vez que tal término viene a designar, desde el extensísimo trabajo del herrero a la delicada labor del joyero, en sus múltiples manifestaciones.

y tanto más extraño es que no aparezca tal palabra en el Diccionario de la Academia, constando en cambio Metalista (versado en metales) y Metalario (el que trabaja en ellos); siendo esto más de notar cuando en las Exposiciones se emplea la denominación de "Artes Metalúrgicas", según hemos leido en varios de estos Certámenes, confundiendo el medio de extraer los metales con la definición de esta industria especial artística.

Justo es confesar que en la Exposición Retrospectiva del año 1867 vimos aparecer esa casi ya desusada palabra al denominar con ella un 
grupo genérico de aquel certamen, lo cual demuestra su necesidad; pero la vemos confundida a veces con Metalurgia, que designa las operaciones mecánicas para preparar los metales y sus combinaciones, extensiva al estudio de su extracción de las minas.

También se da el caso de no emplear la denominación propia del obrero que ejecuta estos trabajos mecánicos, designándole con el nombre de artífice, cuando en rigor su acepción propia es la de metalario (voz genérica para designar el que trabaja en metales), mientras el artífice es el ejecutor de alguna obra en la que pudiéramos considerar predominante el aspecto artístico.

Muy usual era llamar en centurias anteriores alarife (maestro de obras) al arquitecto, del propio modo que la de Toréutica, denominación de labor en metal, comprendía lo mismo el oficio de herrero que el arte de esculpir bajorrelieves o estatuas en bronce, diferenciándola de la Orificia u orfebreria, destinada generalmente al trabajo en metales preciosos.

Podemos, por lo tanto, definir la Metalistería diciendo, que es el ejercicio de toda labor artística ejecutada en metal, según los diversos procedimientos de su labra, comprensivo lo mismo de la herrería que del repujado, orfebreria, cincelado en bronce, platería, etc., etc., y llamar Rejería a la labor monumental artística del hierro.

Al comenzar el estudio de las obras españolas de nuestros rejeros y cerrajeros, consignando cuantos datos hemos podido reunir respecto a fechas y autores, nos daremos por satisfechos si aportamos alguno nuevo para el estudio del arte industrial, acompañando dibujos, casi todos del natural, asi como fotografias que puedan servir de complemento a estas lineas, pasando a grandes rasgos sobre los primeros siglos de nuestra Era, hasta encontrar datos más claros acerca del objeto principal del epigrafe de estas lineas. 


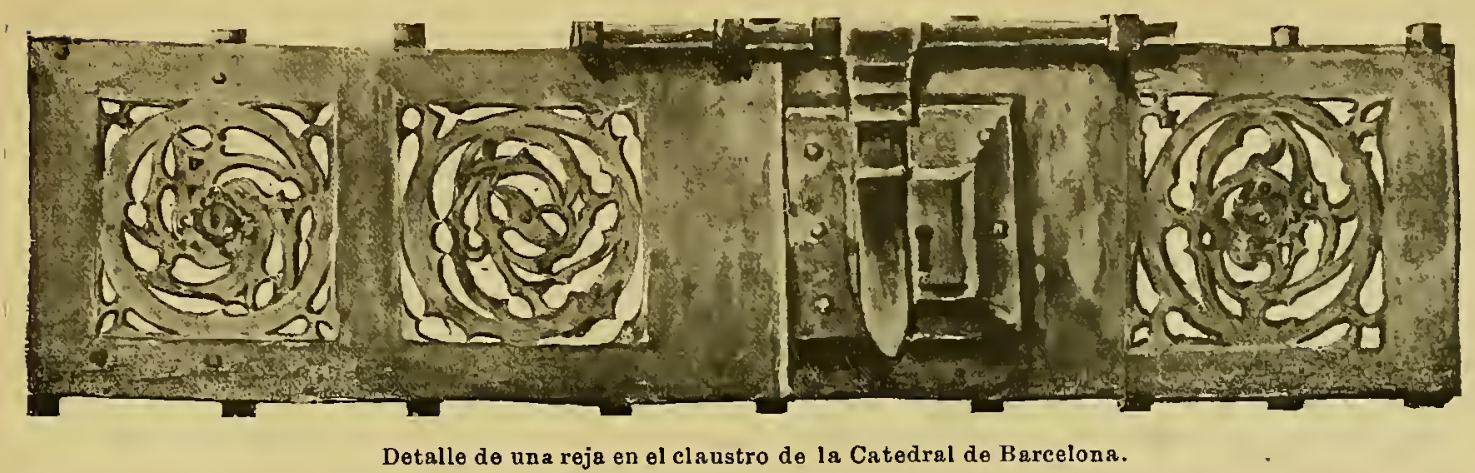

\section{HIS T O R I A}

\section{ÉPOCA PRIMERA}

\section{Desde los orígenes del hierro hasta el siglo XII de J.-C.}

Es el hierro un metal conocido desde remotísimo tiempo, pues se le ve aparecer laborado por el hombre en los días del período proto-histórico, conviniendo todos en el utilísimo servicio prestado por su descubrimiento, dadas sus múltiples aplicaciones.

Atribuíasele origen divino, y por esta causa la historia designaba ya como primer herrero a Tubal-Caín (Tubal el forjador), conocido por su fortaleza "como escoria del hierro» cual símbolo de indestructibilidad.

En Egipto, desde la cuarta dinastía de los Faraones fue empleado con la denominación de «materia del cielo», mencionándose el año 1700 antes de J.-C., en que un oficial de Tutmes llevó al Egipto, procedente de Siria, unos platos de hierro; y Víctor la Place, en varias excavaciones cerca de Nínive, en el Palacio del Rey Sargón, descubrió utensilios, instrumentos y objetos de hierro; pero debe tenerse presente que por lo que se refiere a las costumbres religiosas del pueblo egipcio, les impedían el uso de este metal, según manifiesta Mariette, el considerarlo como "hueso de Tifón», y por lo tanto, impuro y enemigo de Osiris.

Los griegos designaban el hierro con el nombre de "Síderos" (astro) obedeciendo tal vez al origen meteórico de algunos ejemplares de este 
metal, muy semejante a la procedencia de «la piedra del cielo» del pueblo copto, siendo célebre entre los griegos el maestro forjador Hippais.

Recordemos que este preblo prefería el bronce al hierro por su brillo parecido al oro; dígalo si no las puertas de sus templos y epistodomos (donde se gruardaba el tesoro expuesto a la adoración, resguardado por una reja de bronce), si bien reconocían la superioridad de las armas de hierro, designándose esta materia en la Hliada y en la Odisea con el epíteto de "metal difícil de trabajar».

Que en época muy remota era usado el hierro por los indios, atestíguanlo los libros sagrados de aquel pueblo, que lo denominaban "Rhadram" (brillante), y con posterioridad se debió a los hebreos la elaboración de objetos perfeccionados, considerando a los comerciantes fenicios como importadores en España de utensilios de este metal, que también trabajaron, no faltando quien asegure que ni éstos ni los emigrantes griegos introdujeron entre nosotros tal industria, ya conocida anteriormente en la parte Norte y Sur de la Península.

Al determinar con el nombre de Edad de bronce una época histórica, no es decir que se desconociese el uso del hierro en este período, sino que fue poco extendido, si bien apuntaremos la simultaneidad con que apareció el hierro en las dos épocas prehistóricas denominadas Edarl del bronce y Edad del hierro, a juzgar por los objetos hallados en excavaciones. Las rentajas del segundo sobre el primero siempre, desde la antigiiedad, se ha hecho notar, por considerarse como elemento utilísimo para la industria, el comercio, la civilización y el que lia producido al hombre mayores beneficios prácticos, pudiéndose decir, según el pensamiento del Sr. Pérez Villamil, que los repetidos golpes del martillo de los herreros considéranse cual oscilaciones del péndulo en el progreso de las naciones.

No habiendo porqué negar la dificultad en los primitivos tiempos de combinar las aleaciones propias para la obtención del bronce, materia que la naturaleza no presenta en estado nativo, como sucede con el hierro (1), debióse indudablemente a esta facilidad su uso, desde que fue descubierto el modo de beneficiarlo; esto no obstante, su industria estaba ya muy adelantada en el siglo $\mathrm{X}$ antes de J.-C., a juzgar por el fragmento de cota de malla egipcia de acero conservado en el Museo Británico.

Pasadas las nebulosidades de las primeras centurias, consta el establecimiento de esta industria en muestra Península en la época de los ibe-

(1) Aunque decimos nativo, generalmente le acompaña el carbono en diversos grados de riqueza, constituyendo tres clases: hierro dulce, de 0 a 0,25 por 100 de carbón; acero, de 0,50 a 1,50 por 100 , y el hierro colado o fundición, que tiene de un 2 a un 5 por 100 de carbón. 
ros, según atestigua Plinio, a la vez que celebraron los romanos nuestro grado de adelanto en esta industria sobre los demás pueblos de Oriente por ellos conquistados.

España, región minera por excelencia, abundante en hierro, en especial la parte Norte, fue para los fenicios y cartagineses un estímulo grande dado su espíritu comercial, por lo que desarrollaron y exportaron aquellas industrias dentro de la Península y por el Mediterráneo.

Las minas de plomo argentífero en Cartagena; de cobre en Huelva; estaño en Asturias, y las de hierro en la parte Norte, debieron influir de un morlo notable en la elaboración de objetos, especialmente para las armas, dado su carácter bélico; estando convencido aquel pueblo de la superioridad del hierro sobre el bronce, en virtud de la tenacidad y fortaleza de las espadas o armas españolas, que sobrepujaban a las de otros países, y que indudablemente contribuirían a dester'ar el empleo del bronce, ya fuese por la calidad de las aguas para el temple, o el secreto de su fabricación; pero lo cierto es que tomó gran incremento entre nosotros la industria siderúrgica en los cuatro siglos anteriores a nuestra Era, siendo España la que extendió este progreso por las demás naciones, al no existir otro pueblo donde las obras de hierro hubiesen alcanzado tanta perfección, ni artífices que pudiesen competir con los nuestros; llegando después a tal grado, que bien podemos llamarle muestro metal propio, y el que en todos tiempos hemos preferido, tanto para los enseres de la vida como para la labor artística.

El primer empleo de este metal en la Península supónese debido a los iberos y celtíberos, que supieron beneficiarlo mediante el empleo de la llamada forja catalana, dispuesta ingeniosamente para obtener su fundición.

Ocupaba su centro el hogar abovedado limitado por gruesas piedras, formando el crisol nna gran losa arenisca ligeramente cóncara, que descansaba sobre un macizo de escoria, o ma piedra de molino en desuso: aunque carecía de chimenea, practicábase en el techo un gran agujero; ejercía de fuelle o soplete una torbera, dispuesta de modo que la corriente de aire fuese continua, ya producida al caer del ag'ua de ma rueda hidránlica, o aprovechando un salto de ella, por lo que se activaba la combustión lo suficiente para poder fundir el mineral.

Ejemplares sobresalientes que indican el grado de adelanto entre las primitivas industrias del hierro son las espadas ibéricas de Almedinilla (Córdoba) y muchas unás después descubiertas, repartidas las primeras en el Museo Arqueológico de Madrid; en el de Córdoba; colección particular de Alcalá la Real; Museo de Artillería de París, y en la colección Estruch 
que hubo en Barcelona, adquirida por un francés residente en Tolousse, donde se halla instalada, así como gran variedad de armas, de un temple tal, que las victorias alcanzadas sobre los romanos se cree fueron debidas.

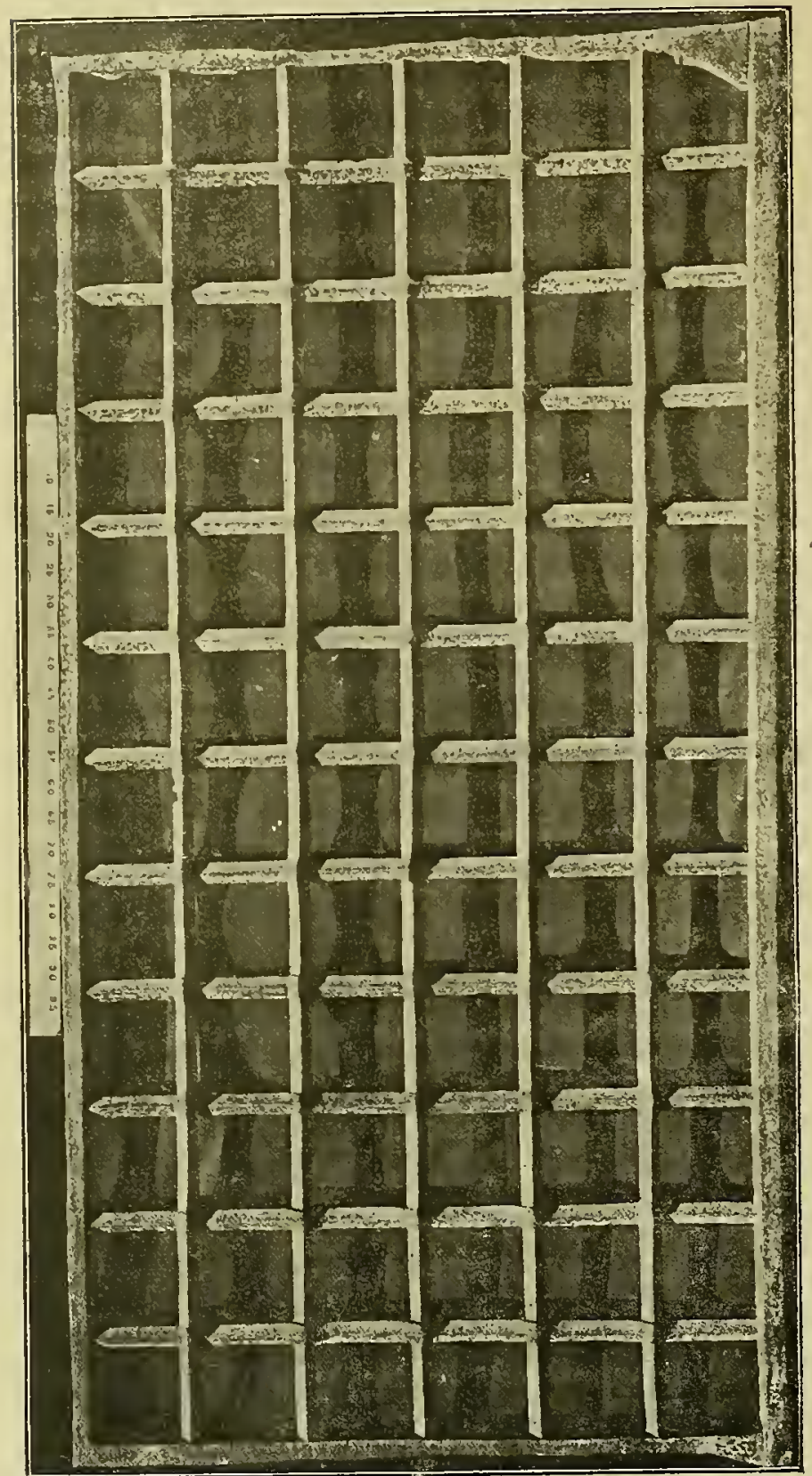

Reja procedente del anfiteatro de Itálica. (Museo Arqueológico de Sevilla.) a la calidad o trabajo de ellas.

Pero no sólo para las armas, sino en muchos útiles de aplicación doméstica, en los instrumentos de labranza, en los arreos de los caballos y liasta en el exorno personal, utilizaron los primitivos españoles el hierro, - como se comprende ante los abundantes objetos de él exhumados en las modernas excavaciones.

PERÍdO ROMANO Y VISIGODU.-Los romanos continuaron extrayendo y labrando el hierro abundantemente entre nosotros, siguiendo las prácticas indigenas, siendo ejemplar muy notable en nuestra especialidad la reja procedente del anfiteatro de Itálica, y que se conserva en el Museo Arqueológico de Serilla; curiosa obra, constituída por gruesos barrotes de hier'o con cruces alteruados, macho y hembra en cada uno, de incomprensible entrelazado, que demuestra el ingenio del rejero que la ejecutó con enlace tan extran̂o. Otra pequeña reja de semejante labor existe en una casa solariega de Manresa. 
Consérvanse también algunos, aunque escasos, objetos de hierro visigodos, entre ellos el notable bocado de caballo todo damasquinado en plata, de la Real Armería, con algunos otros ejemplares parecidos en distintos Museos y Galerías.

Período ẢRabe. - Fuera de las armas y utensilios domésticos no fueron las rejas y exornos de hierro los más empleados por los árabes, pues usando principalmente para sus huecos las celosías de mármol y de madera, y en las puertas el chapcarlo y clavazón de bronce, cítanse como ejemplares de la mayor antigiiedad, según el Sr. D. Rafael Contreras, las rejas plateadas y puertas doradas de un alcázar en tiempos del Califato, que por su posición, época y coste, debió ser el de Medina Zahara, distante tres millas de Córdoba.

La cerrajeria morisca demuestra los ingeniosos conocimientos de sus artífices en los dibujos geométricos de las rejas, arcas para caudales, como las que existieron en la Allambra, de complicada labor y mecanismo de sus cerraduras; llaves proced entes de fortalezas ocupadas por los sarracenos, muclias de las cuales ostentan en sus guardas leyendas con caracteres cúficos o nesgis; claros para decorar, reforzando a la rez, las puertas. Pero donde mostraron mayor grado de adelanto fue en la combinación de la orfebrería con la herrajería, ilustrando y embelleciendo los objetos más lujosos al incrustar en ellos el oro y la plata, en labor tan delicada como constituye la llamada de ATAujía o sea el damasquinado. Sin ser ellos los inventores de esta especial labor metálica, no cabe duda de que la perfeccionaron y dieron un carácter singular, enriqueciendo así sus armas, arreos, cajas, lámparas y cuantos objetos de hierro quisieron ornamentar.

El estilo especial de esta decoración, sus entrelazados y hojas, se prestaron mucho al mayor efecto posible de este trabajo, llevado por ellos a tal perfección, que se les ha considerado por algunos como sus inventores; pero mucho antes se renía practicando por los pueblos orientales.

Nacido sin duda entre ellos, ya lo conocieron los egipcios, como se ve en la preciosa figura de la dama Taluxit, del Museo de Constantinopla, observándose también en la estatua griega del Amiga de Delfos, bronce del siglo $\mathrm{V}$ antes de nuestra Era, en el que se siguieron las prácticas de Glaucos de Chíos, que se supone su introductor entre los griegos, así como en varias figuras y enseres etruscos.

Entre nosotros es muy notable ejemplar, a más del de las citadas espadas de Almedinilla y otras del Resorio en el Museo de Comillas, el llamado plato de Otrinez, de la época romana, pasando después esta práctira 
a los visigodos, según el bocado de caballo de la Armería. Pero ninguno desarrolló tanto este trabajo como los árabes.

Escasos son, sin embargo, los objetos de hierro que de ellos nos han llegado; fuera de algunas armas y jaeces de caballo, con objetos de labranza de escaso arte, pueden darse por perdidos los productos de aquellas fragnas de Andalncía y Valencia, que adquirieron tanta fama por sus armas, cajas y llaves, más conocidas estas últimas, como puede verse en la Catedral de Sevilla, donde existe una de hierro cuyas guardas forman la cifra all sul, el imperio sólo es de Dios, con otras semejantes que pudieran citarse (1): a éstas debiéramos añadir algún cerrojo o herraje propio de ciertas pnertas, pero siu labor extraordinaria, pues las más notables estaban revestidas de chapa y clavazón de bronce, con hermosos aldabones, al estilo de los de las Catedrales de Córdoba y Sevilla. Por esta razón no nos ocupamos de la lámpara árabe traida de Orán por el Cardenal Cisneros, donarla por éste a la Universidad de Alcalá y conservada hoy en el Museo Arqueológico Nacional. por ser obra fundida y cincelada en bronce, aunque de las más notables entre las de metalistería árabe.

Durante todos aquellos siglos de auge del poder musulmán, no cesaron entre nosotros de ser cultivadas las industrias por los cristianos, hasta el punto de ser muy utilizadas por sus dominadores. No por ello dejaron de construirse iglesias mozárabes, en las que comenzaron a tener aplicación para su mayor seguridad y defensa, aquellas obras de rejería que habrían de obtener un carácter tan marcadamente artístico.

En el siglo XI los presbiterios, coros y capillas comenzaron a ser separados por rejas del resto de los fieles, a la rez que quedaba así mejor guardado el tesoro de las imágenes y reliquias.

Sencilla de líneas la reja de este tiempo, es más bien un medio de seguridad que un objeto artístico, aunque bien pronto se manifestó por parte de sus constructores el deseo de embellecerlas: unos barrotes robustos cuadrados, verticales, cruzados por otros horizontales, era el tipo primario, si bien pronto comienzan a aparecer los extremos retorciclos en forma de volutas, motivo que había de tener gran aplicación en tiempos posteriores. Sólo nn tramo formaban estas rejas en toda su altura, por ser bajos los arcos semicirculares que cerraban, constando la puerta de una sola hoja y ofreciendo en todo la mayor sencillez y hasta rudeza.

(1) Véase Museo español de Antigüedades, tomo II, y Boletin de la Academia de la Historia, 1910, pág. 450 . 


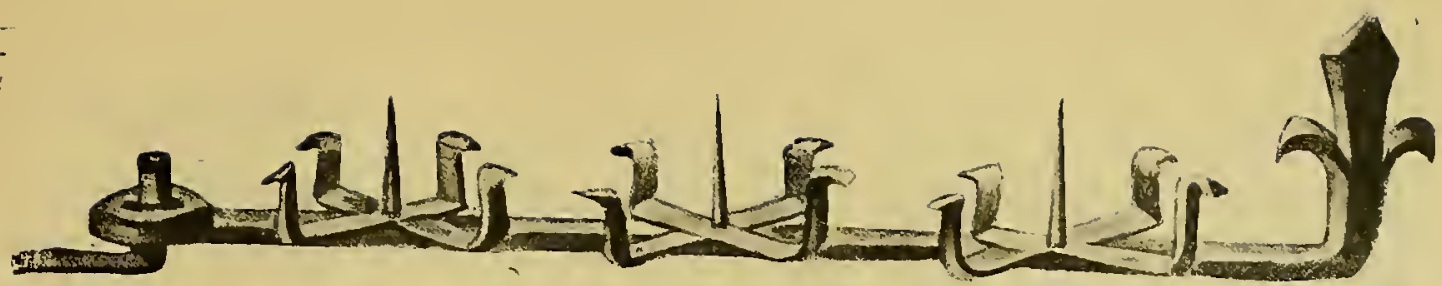

Palmatoria giratoria del siglo XII. (Museo episeopal de Vich.)

\section{EPOCA SEGUNDA}

\section{Períodorománico-ojival.}

SIGLo XII. - En Espańa adquirió ya desde esta época gran desarrollo la industria del hierro forjado, haciéndose los primeros ensayos para soldar el hierro a martillo, cuyo progreso admiramos en los chatones $y$ chapas que cubren como elemento decorativo y de refuerzo las puertas de madera; pero a fines del siglo se ven ya discos de aquel metal soldados y recortados con relativa perfección, dada la falta consiguiente de máquinas destinadas al efecto.

Propio adorno de las hojas de puerta en las fachadas románicas fueron estos herrajes, que venían a darles fortaleza extremada, de las que pueden servir de ejemplo la que damos en el apunte, que se guarda en el Museo episcopal de Vich, y una, sin duda, de las más antignas que pueden ofrecerse. Su superficie está cubierta por cintas de hierro forjado y otras barras aplicadas con clavos, que partiendo del centro, se elevan $y$ descienden en forma de abanico (detalle muy raro en este período), teniendo todos sus extremos rematados en espiral.

Esta puerta forcinea, así llamadia en el Catálogo, hace recordar la de San Juan de las Abadesas, como los hierros de Marsebols (Pirineos

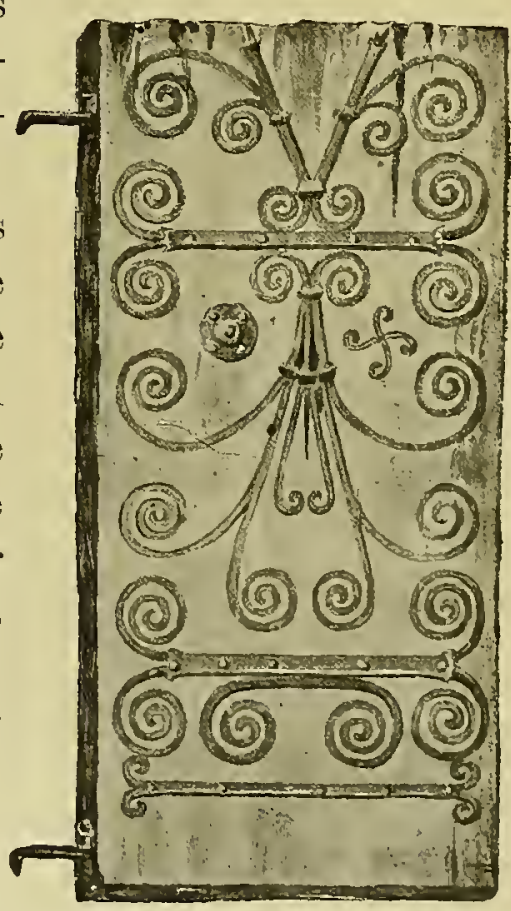

Puerta foránea, en el Maseo de Vich. orientales), ofreciendo la típica labor de los maestros de la comarca del Rosellón.

El estilo más general de estos herrajes aplicados a las puertas en este. 
período es el de prolongadas palmetas horizontales, constituídas por repetidas volutas, viniendo a formar como los extensos goznes que se introducen en los pernios, como se observa en los ejemplares que damos en la lámina, el primero de la colección del Sr. Rusiñol en Sitges (Can-Ferrat) y el segundo, posterior ya, de la puerta de San Miguel de Estella, siguiendo la tradición del siglo XII. Aún los clavos no obtienen especial importancia en estas puertas, igualmente que los aldabones.

El carácter general de las rejas en este período es el casi único empleo de la volnta como elemento decorativo. Esta se extiende a uno y otro lado de un barrote central, sujeta por clavos o abrazaderas, con giros más o menos complicados, y llegando a terminar en una punta saliente, que a reces se transforma en una hoja, flor o espiga, que les sirve como de defensa y les proporciona cierto claroscuro.

Notables ejemplares existen de rejas de esta época, tales como la de la ventana de Nuestra Señora del Mercado, en León; la de Santa Ana, de Barcelona; la del Sagrario, de la Catedral de Palencia, y sobre todas, por la perfección de su labra, la de la capilla de las Santas Sabina y Cristeta, en San Vicente de Avila, estudiada detenidamente por D. José María Baldo (1), y de la que dice el Sr. Repullés y Vargas, en su monografía sobre la Basílica de San Vicente de Avila, que "fue la que constituía el cancel que separaba la nave del chorus, y por su semejanza con los del la Soterroña, de la misma iglesia (la cripta) y otras del siglo XI y XII, tales como la de la Catedral de Jaca y la de Puy en Velay, puede estimarse de los objetos más antiguos de la Basílica", an̂adiendo además que: «El análisis de su construcción, en armonía con los procedimientos entonces empleados para el trabajo del hierro, nos haría entrar en extensas disquisiciones. Sin embargo, no puedo menos de apuntar que, como en aquella época no existían los medios de fabricación introducidos por la industria moderna, había que extender el hierro en placas o barras a mano, lo cual era de gran dificultad para obtener barras largas de espesor nniforme y bien escuadradas. Esto explica porqué las antiguas rejas están compuestas de pequeños trozos forjados, formando combinaciones y sencillos trazados» (2). Esta verja obtiene hoy 1,54 metros de altura.

Aunque sin fecha determinada, pudiendo algunas alcanzar al siglo XIII, son dignos de especial mención en esta época las rejas de San Isidro, de León, la del ábside de la Catedral vieja de Salamanca y la del clanstro de la Catedral de Pamplona.

(1) Véase La Ilustración Española y Americana, 1885, I, pág. 115.

(2) «Basílica de San Vicente, de Avila». Bibl. del Resumen de Arquitectura, 1894, pág. 91. 
En el Museo Arqueológico Nacional, en el diocesano de Vich y en la rolección del Sr. Rusiñol, se guardan curiosos fragmentos de la rejería de este tiempo, muy interesantes y dignos de estudio.

Los candelabros en esta época, construídos por los herreros y destinados al alumbrado particular o litúrgico, afectaban diversas formas en la parte donde colocaban el cirio, pero lo más usual era constar de un sencillo fuste cuadrado, rematado en punta, para poner la antorcha, pues los de cubillo no vinieron hasta más tarde.

Esmeráronse los herreros en la rariedad de candelabros: habíalos de tres tallos, que terminaban en punta, surgiendo de una especie de bandeja cuadrada de bordes festoneados, y en los áng'ulos cuatro discos a guisa de arandela con su correspondiente pincho central; otros aparatos eran las palmatorias giratorias, consistentes en una barra horizontal, unida por un extremo a un pernio clavado en la pared, sobre el cual giraba, terminando el otro en una flor de lis, y en cuya longitud colocaban tres o más arandelas con pincho, que sostiene la antorcha; las linternas portatiles, para acompanar al Viático, procesiones u otros usos, y las tamparas colgantes, fueron otros tantos objetos que empezaron a prodigarse.

Mediante sencillo aro de hierro plano construyeron las coronas de luz, colocando sobre aquél unos pinchos a determinadas distancias, con objeto de situar las luces, e inscribiendo interiormente al círculo varillas en forma de cruz para mayor sujeción, quedaba suspendido todo por tres varillas convergentes en la parte superior.

Las cerraduras eran sencillas, pues se reducían a una caja reelevada a martillo y aristas viseladas, cubierta con una placa batida de hierro, que sostenía el mecanismo de la cerradura, cuya forma no cambió hasta el siglo XV.

En cuanto a los chatones primero, y posteriormente a los clavos para reforzar decorando a la vez las puertas, débese su introducción en España a los árabes, aplicándolos durante el período románico, o sean los siglos XI y XII, como motivo ornamental, que recuerdan a las "puntas de diamante» en la arquitectura (clavo de cabeza cuadrada con cuatro caras a modo de pirámide rebajada), o simplemente el clavo de semiesférica o cónica cabeza.

Andalucía conservó variados modelos de este género, efecto probablemente del largo tiempo de residencia de los árabes; así como en el resto de la Península se ren abundantes y hermosos ejemplares de esta industria especial, que perduró por muchos siglos como principal exorno de las puertas. 
Los nombres de los rejeros de estos siglos nos son por completo desconocidos, quedando como anónima su esmerada labor, de la que hasta la siguiente centuria no bemos de conocer a algunos de sus autores.

SigLo XIII.-De conformidad con el estilo de las nuevas construcciones arquitectónicas ojivales en que precisaba dar mayor elevación a los arcos apuntados, y por lo tanto, a las entradas de las capillas, fue necesario adoptar tirantes en las rejas, que formasen compartimentos para cubrir la total altura.

Con esto surgió un nuevo modelo, cuyos barrotes inferiores eran de mayor longitud que los sobrepuestos del cuerpo superior, requiriendo además, por la anchura de la entrada a la capilla, aminorar el espacio mediante unos machos (columnas o barrotes gruesos de hierro), colocados lateralmente, a los cuales se sujetaba la puerta de la reja, sin perjuicio de los pilares de fábrica, donde se verificaba también lo propio en la totalidad de ella.

Ostenta en este periodo la parte superior de las rejas, una especie de crestería formada por pinchos dispnestos hacia afuera, sirviendo de ornato a la rez que de defensa, motivando generalmente este adorno los pétalos de una flor semejante al lirio o azucena; continúan los trazados geométricos de cintas y roleos combinados con barras cuadradas recordando al bizantino y el árabe, viéndose en amigable consorcio la fusión de los dos elementos: el cristiano en la ojiva y el árabe en algunos detalles, a mediados del siglo XIII.

Otros de los dibujos hábilmente combinados de este período son las rarillas dispuestas a $45^{\circ}$, que al cortarse con otras de igual inclinación producen un cuadrado, suscribiéndose dentro de él un anillo con cuatro lóbulos y rerelando gran adelanto en el ajuste, generalmente sin soldar.

No son muy abundantes, sin embargo, las rejas ejecutadas en la XIII centuria, efecto de haberse concluído muy tarde las construcciones ojivales a que habrán de ser aplicadas, así que, a más de las que hemos dicho, continuando aún el estilo de las románicas, apenas pudieran citarse algunas más en nuestras Catedrales e iglesias.

Algunas reces introducen en el adorno de las rejas siluetas de figuras u objetos, que si bien no muy correctas, ostentan cierto carácter religioso o heráldico, muy en armonía con la época y el objeto a que son aplicadas. Principios al fin de motivos ornamentales que habían de adquirir después tan gran desarrollo.

Igualmente siguen como labor de artistas desconocidos, si bien enton- 
ces surgen los nombres de los maestros catalanes BLA y SUÑoL, que en 1250 realizaban una obra realmente artística, aunque lejos de nosotros, para mayor gloria y fama. Ellos fueron los encargados de ejecutar las famosas rejas de Nuestra Señora de París, y con ellos se abre la lista de nuestros eminentes maestros de la forja.

Candelabros: siguen con bastante semejanza a los del siglo anterior, salvo pequeñas variantes; los denominados de lirio por la forma de esta flor, adquieren mayor gracia y perfección, consistente en un vástago formado de barras que se extienden para dar lugar a un pie triangular, con uno o dos nudos en el fuste, terminado en un pincho para colocar el cirio, peculiar de la región catalana, si bien empiezan a ser sustituídos por los de arandela y macolla cerrada, revistiendo el sello especial del estilo gótico que caracteriza a aquella comarca.

Introdujéronse innovaciones de más gusto por los herreros en las coronas de luz, haciéndolas dobles, compuestas de dos aros concéntricos, uno superior horizontal, con tres hierros convergentes para poderse colgar, unido a otro mayor inferior, paralelo, soportando entre ambos cierto número de mecheros, donde se colocan las luces, cuyo tipo, aunque variado, constituye la estructura más general.

Los atriles y taburetes para colocar libros litúrgicos acusan la forma de tijera, y fueron otra de las obras de los herreros de este tiempo; inícianse en tal época estos enseres de hierro, más cómodos para el transporte que los construídos antes de madera, en los que cubrían con cuero la parte donde colocaban los libros o el asiento.

El uso frecuente de los cofrecillos en la Edad Media, dedicados a g'uardar objetos de valor y poder llevar alhajas consigo en los viajes, fue causa de generalizarse este mueble, conocido ya en la época bizantina; pero con el carácter especial de obra de herrería puede decirse que data (le este período: revestíasele con chapas, nervios, asas y artística cerradura, pres como eran de madera, precisaba forrarles de telas ricas o pergamino, reforzándolos con herrajes más o menos artísticos, según la mano del ejecutante, que servían además de exorno, pintados a veces o dorados, para mayor efecto de riqueza.

Hay quien cree ver el origen del cincelado en hueco en los primeros troqueles de tenaza para estampar en plomo los castillos y leones simbólicos de los sellos de la Monarquía castellana en el siglo XIII, época que concuerda también con el empleo por los antiguos ferreros en España de una especie de impronta recortada con tijera sobre papel, de aplicación muy útil para los dibujos en el hierro. 
Con este sistema, oriundo de los árabes. obtenían dibujos repetidos, formas geométricas, constituyendo un medio de señalarlos con eerteza sobre el hierro, al emplear un papel especial llamado Cepti, que, según el señor Rico Sinobas, había en aquella época: obtuvo este procedimiento. denominado Grofidia por los eerrajeros de siglos posteriores, tal grado de perfección, que llegó a constituir eseuela, perdiendo su importancia artística a fines del siglo XVI (1).

Usíronse en el último períorlo de la décimotercia centuria las cerraduras de pestillo o pasador, revestidas de ehapa calada de aeeidentado contorno, y comenzaron a adquirir importancia artística los llamadores de puertas, que constaban de ma plaea cuadrada o cincular, perforada, sobre la cual colgaba el martillo, generalmente en forma re anillo robusto, bien forjado y de ineisas labores.

SIgu XIV. - Gremios. Surge descle los últimos años del siglo XIII un moviniento espontáneo en España en determinados oficios, del que no prescindiremos tratándose de la herreria, siendo las regiones de Valencia. Cataluna y sevilla en las que la agremiación obturo mayor éxito.

Como resultado de nuestras investigaciones rerificadas en el archivo del Gremio de Cerrajeros, de Barcelona, hoy llamado «Colegio de Maestros Cerrajeros, Armeros y Agujeros", úmico tal vez en España con archiro y casa propia (calle del Consejo de Ciento, número 292), resulta que en la época romana ya se eonocían los oficios establecidos en eorporaciones, a juzgar por una lápida de aquel período dedicada a Minerva, por el colegio de Artífices Barceloneses, encontrada en dicho templo, y que hoy se halla en un ángulo de la ealle de Hércules, detrás del Monte de Piedar y Caja de Ahorros.

En 1200 Pedro II cita en las Constituciones catalanas, la eorporación de Ferrers, y en un pergamino del Consulado del Mar consta, que los Ferrers de Barcelona tenían derecho a construir todos los herrajes y piezas neeesarias para la marina sin pagar derechos, sienclo en 1380 aprobadas por Pedro IV las ordenanzas del gremio instituído bajo la advocación de San Eloy, que dos siglos más tarde se subdividieron, constituyéndose en Cofradias de Herreros, Cerrajeros, Cuchilleros y Espaderos; merece consignarse que el gremio de Herreros, en París, se fundó algunos años después que en mnestra Península, o sea en 1411; el de Espueleros en 1557, y el de Plateros en 1330, siendo así que en Barcelona sı origen data del año 1316.

(1) Véase Historia y Arte, tomo I, pág. 205. - De la grafidia o dibujos a tijera que usuron en España los antiguos ferreros, por I). Manuel Rico y Sinobas. 
Los Reyes Martín I, Alfonso y Carlos I empezaron a conceder derechos y privilegios a los maestros cerrajeros, verificándose ya en Barcelona la primera fundición de cañones de gran calibre para la defensa de las costas por orden de este último Rey; llegando el caso, dada la importancia del gremio de Herreros, de haber recurrido los renecianos, el año 1360, a la Cindad Condal para proveerse de ballestas, saetas y armas, haciéndose de una vez un envío de mil cajones con estos pertrechos.

Tanto en Aragón y Valencia como en Cataluña emplearon con prodigalidad la palabra almoyna en el siglo XIII, que no es otra cosa sino limosna o auxilio prestado mutuamente entre los asociados, y era obligatoria satisfacerla un día a la semana.

En el siglo décimosexto los herreros adquirieron gran preponderancia, pues a las ordenanzas anteriores siguieron otras, como las de Sevilla en 1502, que fijaba la cantidad de la pieza de prueba pagada por el examinando; y las de Toledo, concediendo privilegios, en 1582, para armonizar estas corporaciones gremiales, que no eran del agrado de los poderes públicos.

Disueltos los gremios en 1714 , se organizaron después los Cerrajeros pasados algunos ańos, hasta que, en virtud de cambios políticos, fueron dismeltos definitivamente en 1835 .

En su origen recibieron el germen estas asociaciones del mediodía de Francia, Mompeller y Limoges, cuyo régimen admirable comprendió tres categorías: aspirantes, oficiales y maestros.

El primero empezaba prestando juramento, y durante el tiempo de aprendizaje se efectuaba un examen ante los miembros de la comisión, ascendiendo a oficial al ser aprobado, previo el correspondiente título.

El oficial cerrajero tenía la ventaja de disfrutar jornal, y ligado por juramento, reconocíanse, mediante signos convencionales que tenían, recíprocas obligaciones para asegurar trabajo, socorros, etc., etc.. hasta el junto, según dice D. Enrique Claudio Girbol, de que cuando uno de ellos llegaba a una población donde toclas las plazas estaban ocupadas, el más antiguo cedía la suya al recién llegado en busea de trabajo.

Reqneríase para la obtención de aptitur ma instancia dirigida al Prohombre (Presidente del Colegio de Cerrajeros) y examinadores de forja y lima, a fin de ser admitido para verificar un ejercicio denominado pasantía o maestriu, reducido generalmente a hacer nna cerradura, cadena, llave u otro objeto, satisfaciendo después de aprobado seis libras catalanas (la libra catalana equivalía a tres pesetas), sin cuyo requisito no podía ejercer ni establecerse; estos derechos de examen caycron en des- 
nso hacia los ańos 1740 a 42 , según vimos al revisar las actas. Varias de estas llaves de pasantía se conservan en el Museo municipal de Barcelona.

Los maestros debían presentar a la Corporación pruebas de buena conducta para ser admitidos a la «obra maestra», seg'ún el lenguaje de la época, trabajando en presencia de los "grandes examinadores» en un departamento cerrado y exponer después las obras, siempre que así lo acordasen los maestros, y previos los derechos, al ser aprobado, juraba entonces fidelidad en el cargo.

Respecto a las instituciones gremiales de Valencia, también se remonta su origen a los primeros siglos del Cristianismo (Collegia artificum vel. opificum), iniciadas por el Emperador Adriano, sicndo especiales para el obrero a principios de la Edad Media.

Con la fecha 1242 ran señaladas concesiones especiales sólo para los oficios de cerrajeros y forjadores de palas (palaforger:s), hasta que, habiéndose observado abusos en estas Corporaciones espanolas entre los mismos cofrades, las anuló el Rey Don Jaime en su reino, presentándose posteriormente la cofradía desdc el punto de vista religioso, adoptando los herreros como patrón a San Eloy, a semejanza de los de Cataluna, otorgándoles privilegios, ordenanzas y reglamentos desde 1300. Llevaban como insignia en el asta de bandera el santo titular o la alegoría del oficio (el yunque con dos martillos cruzados es el del herrero), y la bandera de color carmín adornada con oro; la de cerrajeros catalanes ostenta dos águilas y cadenas bordadas en oro y plata sobre fondo de damasco encarnado.

En la región valenciana no figuraba el aprendiz antes del siglo XV, pero en el siguiente se fija la edad y duración del aprendizaje, según una minuciosa relación del Sir. Tramoyeres, manifestando comprendía cuatro an̂os para los cerrajeros y herreros a contar descle la edad de quince; habían de vivir en compańía del maestro, alimentados y vestidos por éste, justificando la limpieza de sangre, es decir, ser hijo de cristiano, pues estaban excluídos los moros, judíos y esclaros; la falta de asistencia a la casa del maestro, siquiera fuese por motivo legítimo de enfermedad o ausencia del aprendiz, obligábale a servir dos clías por cada uno que faltase.

Respecto al maestro, previo examen, se consideraba en el reino de Valencia como titulado de experiencia, autoridad y práctica de la profesión; siendo los introductores de este requisito el gremio de zapateros el año 1458 , extensiro después a los herreros, mediante la cuota además de 50 sueldos.

Con el decreto de libertad de industrias, el año 1839, naturalmente 
desaparecieron los gremios de un modo indirecto, perdiéndose el carácter peculiar de tan antigua como importante institución.

El gremio de Cerrajeros de Barcelona usó algunas marcas, a semejanza de los signos de los canteros empleadlas en el época medioeval, sirviendo de ejemplo, entre otras muchas, la bigornia, usada por Juan Tomasino; la llave, de Juan Deop; la tenaza, de Bautista Solé; el martillo, de Pedro Viura, etc., y como signos astrológicos citaremos el Sol, empleado por Carlos Soler; la Tierra, de José Figueras; el sigmo del zodíaco Libra, por .José Sirach, y una estrella, Antón Casadesnunt.

Había obreros que empleaban carla uno un número que servía de distintivo, utilizando otros una letra del alfabeto mayúsculo, aun cuando era más usual las iniciales del nombre y apellido, a veces enlazados, o simbolizando el apellido, como Juan Serra, que dibujaba nna sierra; del propio modo había otras muy curiosas. cuyo significado se desconoce, representativo de una ancla, una bota, el castillo, la mano, etc.. etc.

Los progresos de la arquitectura sustituyendo los arcos de medio punto por la ojiva en el siglo anterior, contribuyeron a que ésta fuese más esbelta en la construcción, dando mayor majestuosidad al elevarse las bóvedas en los edificios denominados ya Catedrales.

Natural consecuencia de este adelanto fue, al ampliar y elevar los arcos ojivales, introducir un nuero cierre en las capillas; careciendo de éste el coro y altar mayor, pues estaba formada su entrada por los grandes arcos torales de sostén de la bóveda central, surgió de ahí la idea de la construcción de las artísticas rejas, de acuerdo con las existentes en las capillas, y aun cuando es cierto que no cubrierou los huecos en su totalidad, se elevaron a la suficiente altura para dejarlos bien defendidos; indudablemente, al dedicar ese trabajo artístico a las rejas, debió obedecer a las pruebas de maestría dadas por los rejeros, motivado por el buen g'usto y la facilidad en aplicar el estilo dominante de cada época, a semejanza de la arquitectura, para servirle de complemento armónico.

Las rejas, o sea este accesorio arquitectónico, hermanando con la construcción apuntada, ya dijimos que empezaron a hacerse de dos o más cuerpos de altura, revelando un grado de adelanto grandísimo en su composición por parte de los maestros rejeros, así como en la técnica, pues las construyeron siempre de hierro forjado, como todas las de la Edad medioeval, pero aplicándose en esta época las placas recortadas y repuja- 
ras, siendo sustituidas las abrazaderas por remaches o roblones, mediante los que se hacía más rápidamente la obra, prueba inequívoca de haber adelantado mucho estas artes industriales.

Dióseles a los barrotes la forma retorcida o espiral, formando la reja con ellos, o alternando otros cuadrados, a fin de evitar la monotonía, mediante combinación de piezas curvas, como trilóbilos o cuadrilóbilos, inscriptos generalmente en ma ojiva, de acnerdo con la arquitectura, cuyos elementos eran idénticos; la disposición de las rejas consistía por lo regular en barrotes de basa poligonal en la parte inferior, sobre los que corre un friso calado o repujado de cardinas, destacándose el dibujo por el fondo de un paño rojo colocado en la parte posterior, según se ve aún en la reja del frente de la capilla del Sagrario en Ia Catedral de Palencia, llevando otro segundo friso superior más ancho y artístico, sobre el que se eleva gallarda crestería.

Ya que desde ahora hemos de emplear con frecnencia la palabra reja, manifestaremos que en diversos escritores consultados sobre el particular, la denominan así unos, mientras otros la llaman verja; pero al examinar la causa de esta indecisión, remos que no se halla muy explícito en aclararlo el "Diccionario de la Leng'ua», pues al definir la primera dice: «es una especie de red formada de barras férreas de diversos tamaños y figuras para la seguridad y defensa», mientras la verja afirma ser «un enrejado que sirve de puerta, rentana o cerca».

Lo característico de la verja, en muestra opinión, es que no llegue a "errar en mucha altura el hueco, o que rodee algún monmmento u objeto, pnes de lo contrario sería llamar impropiamente reja a la del conocido sepulcro de los Anayas, en Salamanca, por ejemplo, o verja a la de una rentana.

Verdad es que concretándonos al caso de este accesorio artístico que cierra una capilla, puede o no llegar a la clave del areo, pues como decimos no es preciso cierre totrimente el hueco, mientras la verja impide el paso y es, por regla general, de poca eleración.

Así, pues, denominaremos reja a todas las colocadas en capillas, coro, puertas y ventanas, y reja, cuando rodee un recinto para aislarle.

Entre la rariedad de rejas de rentana, desde el siglo XIV hasta nuestros días, fueron muy usuales las llamadas de parrilla, construídas por barrotes redondos o cuadrados verticales (machos) que pasan por unas aberturas hechas en otras barras horizontales (hembras), formando esparios rectangulares, producto del encuentro de ambas; también las hay de barras colocadas oblicumente a $45^{\circ}$, dejando los espacios en forma de 
cuadrados o rombos; otras estín curasalus en el paramento de la fachada, impidiendo ver los objetos lateralmente, siendo frecnentes, en los siglos XVI y XVII, las conocidas con el nombre de salientes, debido al resalto o vuelo, pudiéndose contemplar por esta circunstancia los objetos de ambos lados; éstas suelen estar sostenidas mediante ménsulas o palomillas, y provistas en la parte superior de un remate con adoruos, que afectan la forma triangular, protegida a reces por un tejadillo actherido al muro, a una o dos aguas, exornando conforme el grado de sn riqueza los barrotes.

Habialas de antepecho, a guisa de balconcillo, mientras la parte media superior componíase de dos hojas que giraban lateralmente para asomarse con comodidad, cerrándose cuando conviniera. En Cataluña se conocen una clase de rejas sencillísimas (escasas por cierto) y sin importancia al parecer, conocidas con el nombre de reixas de ulls preñats (rejas de ojos pren̂ados); datan del siglo XVII y son muy semejantes a las de parrilla, pero tienen la especialidad de que los agujeros de los barrotes (hembra) están muy juntos y, por lo tanto, expuestos a unirse al abrirlos en la fragua, habiendo visto algunos ejemplares que distan cinco centímetros de eje a eje las barras, como las que se hallan en la Plaza de Santa María del Mar, y las del Hospital cle Santa Cruz, en Barcelona, cuyas obras son de gran estima entre los maestros herreros.

El año 1389 y 1401 los hermanos rejeros BARToloné y .JUAx MoREY ejecutaban en Palma de Mallorca obras importantes de cerragería, siendo también de este período los herrajes que decoran en su totalidad las puertas de la iglesia de Santa María del Mar, en Barcelona, ostentando la puerta principal un revestimiento de barras en forma de cuadrado, e inscripto $\mathrm{um}$

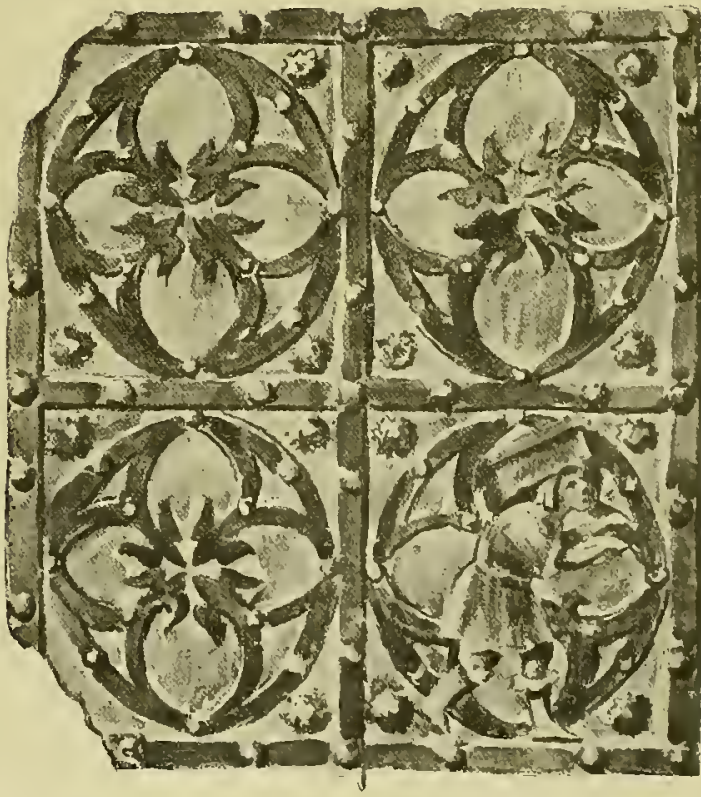

Ornamentación do ia puerta de Santa Maria del Mar, de Barcelona. cuadrilóbulo en cada uno, sujetos con chatones de diverso diámetro, y una pequeńa figura de cobre sobrepuesta, viéndose en la otra puerta lateral una combinación de barras horizontales con otras verticales formando cuadrados, y en su parte media 
una cruz rematando en flor de lis sus brazos, decorados los espacios también por chatones (1).

Sensible es no haber podido averiguar los nombres de los maestros rejeros que labraron las preciosas rejas de la Catedral de Barcelona, a pesar de nuestras pesquisas en el Archivo de los Reyes de la Corona de Aragón, ni en el de la Catedral, pues los escritores al reseñar las obras artísticas del recinto donde se verificaron los funerales del Príncipe de Viana, dejan siempre sin describir las rejas que tan justamente llaman la atención en aquellos claustros.

A propósito de la carencia de firma en muchas obras de rejería, hay que suponer fue motivada por la modestia de los maestros durante la Edad Media, pues en los documentos, convenios y actas, no se advierte la menor alusión a otros conceptos de piadosa humildad, a pesar de las fórmulas notariales al consignar el compromiso de ejecución del trabajo (2).

Entre la colección de rejas de las capillas que rodean el claustro de la Catedral barcelonesa, mas pertenecen a principios del siglo XIV y otras al XV.

La forma general de las rejas al principio de aquel período están caracterizadas por barrotes redondos, de poca altura, presentando en el centro una puerta baja, de dos hojas, limitadas por ancho marco adintelado de palastro, en el cual campean alrededor flores de chapa recortada, repujadas y sobrepuestas, o clavos con cordones que le rodean, obserrándose en la parte superior una serie de arcadas ojivales sobre la crestería compuesta de sencillos rástagos simulando flores de puntiagudos pétalos, divergentes tal vez para impedir el acceso.

A fines de siglo las rejas adquirieron mayor elevación, viéndose la puerta cobijada por dos arcos ojivos coronados de una macolla, así como los robustos pilares laterales terminan en chapiteles prismáticos, revestidas las aristas con adornos de la época, acostumbrando a colocar superiormente un friso, arcadas, o simple fila de rosas de cuatro lóbulos, y coronando todo una serie de puntiagudas flores alternadas con hojas u ojivas.

Las ceradurrs suelen ser chapeadas o caladas por regla general, con

(1) Después de haber copiado del natural los dibujos fueron cubiertas con chapa de bierro las puertas de este templo, entre ellas las dos mencionadas, perdiendo su primitivo carácter.

Esta resolución fue adoptada a causa de los incendios verificados en la Ciudad Condal a fines de Julio de 1909.

(2) En 1384, Bernardo Desplá reparó la reja de detrás del sepulcro de Santa Eulalia en la Catedral de Barcelona (libro de cuentas de sacristía, años 1383 a 85). 
típicos dibujos, provista de su correspondiente cerrojo: el croquis publicado es de una reja del claustro de la Catedral de Barcelona.

Ya manifestamos que una de las secciones de las industrias de construcción en hierro es la Cerrajería; pues bien, mediante su labra se adquiere la forma deseada, de suerte que, salvo determinadas excepciones, no se ha de perder de vista que el objeto hecho de este metal obedece a ına combinación mecánica de contrarresto de fuerzas, obteniéndose el doble fin de hacer más resistente la obra a la vez que se le da mayor belleza, constituyendo el principal mérito saber aparentar esto, aun cuando lo esencial sea la solidez de la misma.

En la Cerrajeria entran de lleno la construcción de piezas de refuerzos o seguridad, como las bisagras orllamentadas, cerraduras, cerrojos, chapas repujadas, llaves, asas, remates y mil objetos, algunos de los cuales se irán mencionando en nuestro trabajo.

Los candeleros, además de destinarse para alumbrar en los edificios religiosos, como también los candelabros, se emplearon en las mansiones señoriales o castillos, viéndose en algunos ejemplares muestras fehacientes de haberse dorado y pintado, dándoles mayor sumtuosidad: constan de pie, fuste y plato, sustituyéndose en este siglo el pincho de la arandela, que sostenia el cirio, por un tubo o dedal, revelando un adelanto para su mayor sujeción, si bien en la alta montaña de Cataluña continuó la forma primitiva, especialmente en los llamados de lirio, a juzgar por las colecciones del Museo episcopal de Vich y la del Sr. Rusinol, en Cau-Ferrat, instalada en Sitges.

Complemento del decorado en hierro de las puertas fueron los artísticos aldabones, según ya expusimos, colocados en mansiones de linajuda estirpe, prodigándose la costumbre de poner umo en cada hoja de puerta de las Catedrales, que afectaban, como en el siglo anterior, la forma de un disco calado, con elementos peculiares del estilo de su época, y la fuerte rodaja con sus caras adornadas de triángulos, dientes de sierra o curras sobrepuestas.

Aun cuando el uso de los morillos de cocina, muy semejantes a los de chimenea, datan de antiguo, en el transcurso del tiempo adquirieron más arte y aplicaciones, decorándolos con cabezas de animales, nudos en el fuste, o a manera de pantalla con férreas labores, observándose en algunos un recipiente en la parte superior para colocar utensilios de cocina.

Continuó también el sistema de hacheros giratorios, aun cuando admitiendo ya el dedal para la sujeción del cirio.

Los rejeros desplegaron su inventiva desde fines del siglo XIV al XVI 
en las palomillas, para aumentar el aspecto artístico de las enseñas, o sea la insignia a guisa de letrero de comercio, cuyo sistema podía aplicarse para aquéllos que no supieran leer', constituyendo un medio alegórico de anuncio del oficio; pues era muy corriente este sistema en la Edad medioeral, explicándose así que se riesen chapas artísticas caladas representando, por ejemplo, unas tijeras o una herradura, para indicar la sastrelía y el reterinario, cnyas enseńas pendían de una palomilla adornada, formando un bello conjunto.

Perfeccionóse el trabajo de la época anterior en cuanto a las grías, saledizos, veletas y grifos o animales quiméricos, así como también en la construcción de cajas para gnardar caudales, pues además de conseguir los cerrajeros la seguridad necesaria, las dieron un aspecto artístico mediante abrazaderas, placas ornamentadas, frisos, cantoneras y clavos.

SIGLo XV.-Durante el mismo la rejería obtiene sus más definitivas formas ojirales, produciendo ya ma importante serie de notables obras, y siéndonos conocidos los nombres de muchos de sus antores.

Los Morey, en Mallorca: Frederich, Loquer y Arnau, en Barcelona; Martín García, en Sigiienza: Juan Francés y el maestro Bujil, en Castilla, con otros, son nombres que se destacan y van unidos a obras de excepcional importancia en el arte del hierro entre nosotros.

Teniendo las rejas, desde fines del siglo anterior, carácter arquitectónico, pasa esta industria a la elerada categoría de miembros de embellecimiento de las iglesias en consorcio con la construcción; por este motivo las rejas, teniendo tipo monumental en este período, cubrieron casi por completo la ojiva, mediante tres o más cnerpos sobrepnestos, sobre los cuales se elevaba la crestería, poblada con hojarascas, entre las que suele descollar una composición central representativa generalmente de la escena del Calvario o el Crucificado. No escasean tampoco ejemplares de rejas coronadas por agudos remates de pétalos de flor, en especial azucenas y lirios, para impedir el asalto, y a veces con chapas caladas, arcos ojivos 1 lojas, pero intercalando con frecuencia los rejeros castellanos los castillos en frisos o cresterías, según se observa en las rejas de las Catedrales de Palencia y Segovia; en las de la casa de las Conchas, en Salamanca, e igualmente en otras ciudades donde aplicaban este elemento decorativo; en cambio se advierte la carencia de tales emblemas en las provincias andaluzas y catalanas, sustituyéndolos en la íltima por la "flor de lirio", ornato que duró algo más de dos siglos.

Colocaban los barrotes rerticales alternando los lisos con los funicu- 
lares, aplicándoles chapas repujadas sobrepuestas y columnas o machones coronados por cornisas de hojas zarpadas, arcos y cuantos elementos ornamentales caracterizan el estilo florido, adquiriendo entonces tal grado de adelanto el arte de los rejeros en la Península, que fue envidiado en Europa, al tener vicla propia en sus múltiples aplicaciones, "que la industria engrandeció en lugar de rebajarle», seg'ún dice Mr. Laborde.

De tal suerte, no sorprende ver en cada región su sello peculiar en las obras de esta índole o en las arquitectónicas: compárense las construcciones gótica y del Renacimiento castellanas con las catalanas, e igualmente las industrias de los herreros, y reremos en las últimas las influencias del arte francés, debido singularmente al modo especial de componer la flora: así lo demuestra el lirio, aplicado con prodigalidad, aun cuando se reconozca revelaron gran gusto y práctica en el forjado, con pocas variantes en este período; bien puede estimarse como carácter propio de la rejería catalana aquella singular habilidad de su martillado, al punto de no tener necesidad de la lima para dar por concluída la obra, produciendo la huella del batido tan variado un aspecto tan bello como característico de la labor del hierro catalana; pero al recordar y compararlos con la originalidad de los rejeros castellanos, son éstos proclamados unánimemente como artistas consumados, en virtud de haber sido algumos arquitectos, plateros o escultores, e indudablemente habían de imprimir en sus obras un carácter innegable de elegancia y buen gusto, tan variado como suntuoso.

Las Ordenes monásticas, no ofrece ducla, contribuyeron a engrandecer estos trabajos con sus fundaciones, contando con hermanos de las $\mathrm{Or}^{-}$ denes prácticos y hasta eminentes en la rejería.

En 1438 se construía la reja del presbiterio de la Catedral de Tarragona, de diez y seis metros de ancho y seis de altura, con bella portada conopial de ingreso y airosa crestería, sabiéndose tan sólo de su autor que fue un rejero de Morella, para el que solicitó el Cabildo el derecho de vecinclad, en atención a que era lo mes antes del regne, é fá la rexa o rexes clebant laltar maior (1).

Los rejeros españoles, en unión con algunos extranjeros, extendieron el arte en nuestra Península, según lo demuestra la verja de subida al púlpito de la Catedral de Barcelona, hecha por el maestro alemán MIGUEL Loquer y su discípulo JuAN Frederrch en 1443, cuya obra citamos por considerar el trabajo eminentemente español; y aquí interesa recordar el precioso púlpito de madera tallada que motivó aquella obra, comenzado en

(1) Véase Morera, D. Emilio: La Catedral de Turragona, 1905, pág. 43. 
9 de Agosto de $1 \pm 03$ por Pedro Anglada, maestro de imág’enes, mediante compromiso consignado en un pergamino ante el notario real de Barcelona, signado por Jaime Rosell y firmado por Anglada, documento que nos exhibió el archivero de la Catedral, en el Libio de Obra del an̂o $1403-2 .^{\circ}$

En 1479 se citan los nombres de Martín Garcia y Eneco o IÑ̇go, que en los talleres de Pamplona trabajaron en la construcción de planchas de hierro y rarias piezas para el ejéreito de Carlos el Noble, de Nararra, habiendo hecho el primero algunas rejas del claustro y capillas de la Catedral de Sigiien$z a$, y unos candeleros para la misma.

Posteriormente el maestro Bujl hizo en 1496 la reja para la capilla de las Reliquias en la Catedral de Burgos, y en Enero de 1499 contrató con los

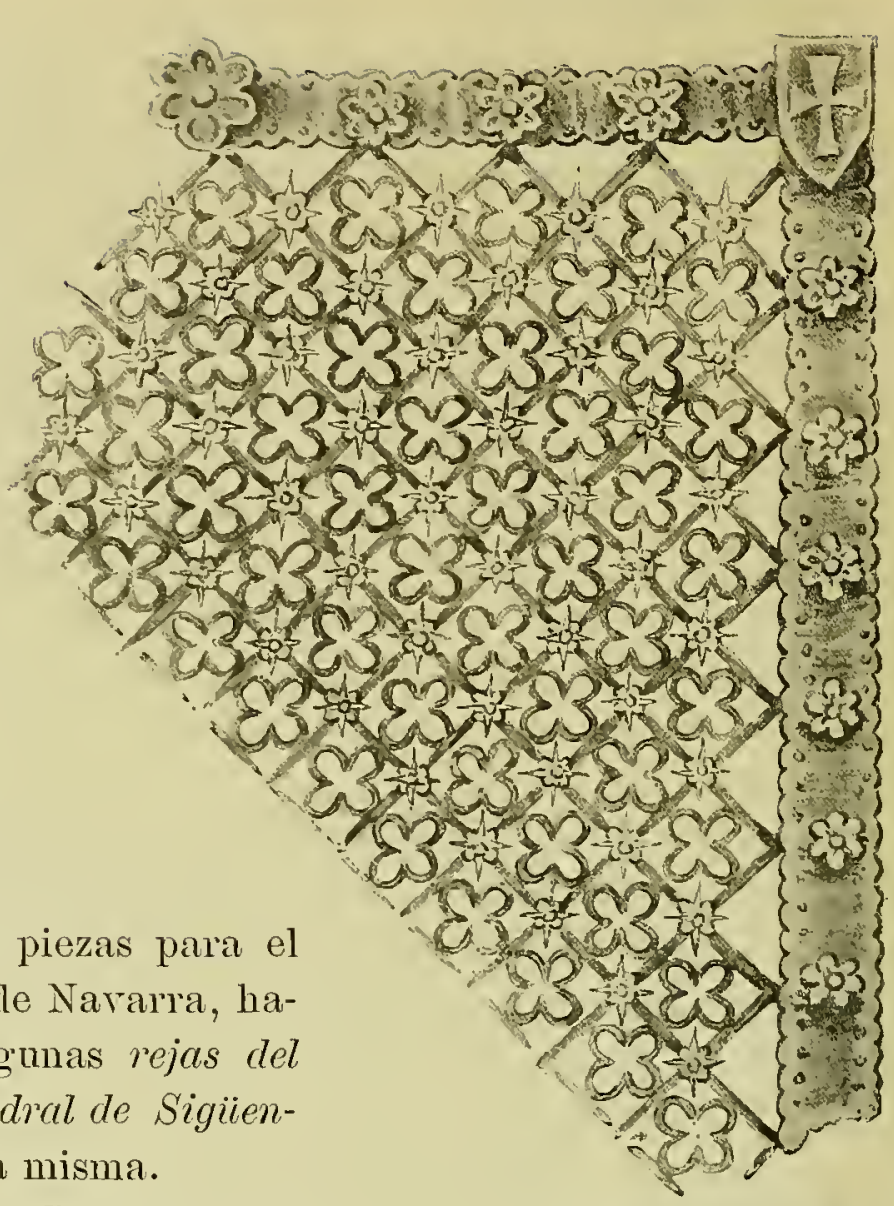

Parte central de la verja del púlpito de la Catedral de Barcelona. obreros la colocación de otra reja en la capilla mayor de la citada iglesia.

Fr. Francisco de Salamajca, al que hemos de encontrar llevando a cabo obras de la mayor importancia, aparece tomando parte en la construcción de la verja que rodeaba el Sepulcro de Don.Juan II en la Cartuja de Miraflores, en 1493 , compuesta hoy, ya muy rehecha y restaurada, de sencillos barrotes, pero desplegando el lujo en la crestería, pináculos y el blasón con las armas de Castilla y León; siendo muy puras por su estilo gótico y carácter castellano, las de las capillas del Bautismo y San Isidro en la Catedral de Palencia, con alguna otra verja de sepulcro en este mismo templo.

No pasaremos inadvertido el nombre de JuAn ARxAU, a quien el Consejo de la ciudad condal nombró Canciller en 1494, con carácter de competente, por haber hecho varias obras de cerrajería, y ocupó aquel elevado cargo en virtud de sus conocimientos, como maestro elegido entre el gremio para que le representase en aquella Corporación. 


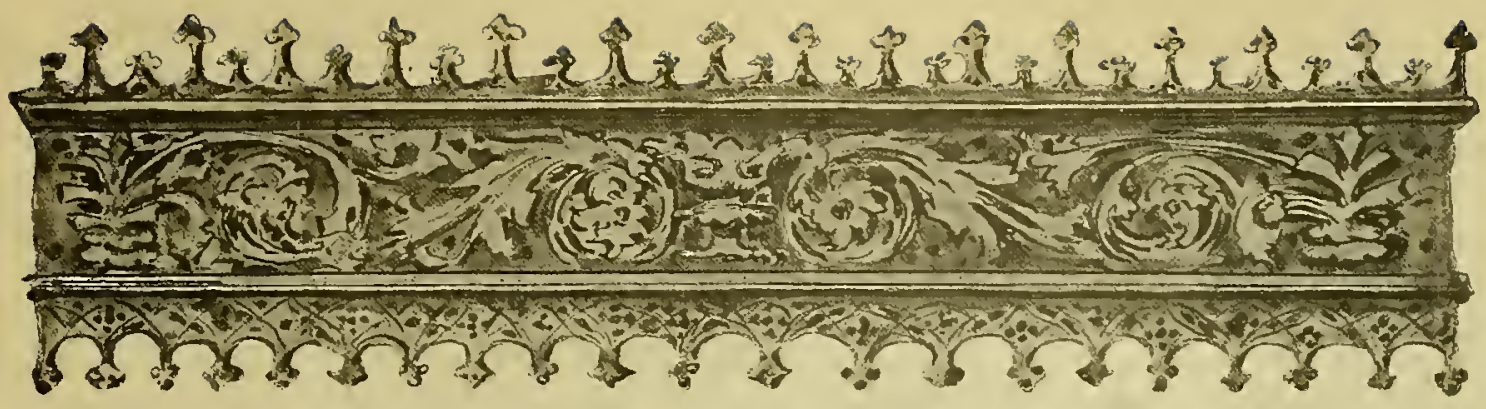

Detalle de una reja del Hospital Real en Santiago de Galicir.

\section{PERIODO DE TRANSICIÓN}

\section{Del Ojival al Renacimiento.}

A todos los artistas últimamente citados preocupaba la dirección que las artes seguian en Italia, de donde llegaban modelos acusando un estilo muy distinto del que por tradición aplicaban; por ello comenzaron tímidamente a introducir ciertos detalles en sus obras, que amalgamaban con sus trazados góticos tradicionales, pero que concluyeron por ensen̂orearse por completo de las artes en todas sus manifestaciones, constituyendo el período llamarlo plateresco.

Mas antes de llegar a éste produjeron una serie de cbras de transición, tan numerosa como original, y cuyos ejemplares ofrecen el aspecto más interesante y nacional que puede presentarse y que se prolongó descle fines del siglo XV hasta todo el primer tercio del siguiente entre nosotros.

Las rejas de este período de transición ofrecen un carácter singular y una ejecución esmeradísima: por la traza presentan un marcado aspecto medioeval, pero en sus detalles se ran posesionando cada rez más del gusto italiano. Sus barrotes verticales recuerdan los haces de baquetones de los pilares ojivales; sus puertas suelen tener gabletes y cardinas; sus baudas horizontales están primorosamente calados y sus cresterías presentan bellísimos conopios lobulados que se entrelazan, sosteniendo escudos y emblemas, con macollas y preciosas figuritas en sus remates. La serie es muy extensa, por lo que merece sea notada, al menos en sus ejemplares más salientes.

Sometido a estas inspiraciones, se presenta JuAx l'RArcés, "maestro mayor de las armas de hierro en España», recino de 'Tolerlo, que debió ser' 
español a pesar de su apellido, y uno de los más antignos y eminentes maestros que figuran trabajando en Castilla.

En 1494 tomaba parte en la ejecución de la reja del Sagrario Antiguo de la Catedral de Toledo, llamado el Vestuario; teniendo fecha del año 1505 las de la capilla mayor y coro de la Caledral de Osma, según se lee en el friso de la primera: "Hizo esta obra el Maestro .Juan Francés, Maestro mayor de Toledo".

En la del coro dice: "Esta obra mandó hacer el muy magnífico señor Don Alonso de Fonseca, an̂o 1505". También son de sn mano la de la rapilla mayor de la Magistral de Alcala de Henares, San .Justo y Paistor; la de la capilla mozárabe de la imperial ciudad, en 1524; suponiéndosele a este infatigable artífice antor de las rejus del coro, frente y costallos de la crpi$7 l a$ mayor en la Catedial de Avilu, siendo Obispo D. Alfonso Carrillo, y los dos preciosos puilpitos, obra del siglo XVI, las joyas más sobresalientes en su género de la rejería espan̂ola, cada una de un estilo, gótico y Renacimiento, como demostrando el dominio que de ambos su antor tenía.

Además de estas rejas que dejamos apuntadas, conserva la Catedral de Sigïenza la que separa la capilla de Santiago de la capilla de la Asmción, que se estima del Maestro Francés, creyéndose son también del mismo las rejas de la capilla de la Anunciación; la de Sronta Librada, a expensas ésta de la Condesa de Medinaceli, en 1520, y ayudándole en la ejecución Martix Garcia, y las de San Pedro y Santa Catalina en la misma Catedral, las cuales son del período de transición del gótico al plateresco, habiendo sido fundada la primera por Fray Fernando de Montemayor (1526-1532), arcediano de Alzán. Quizá a él pudiéramos aplicar también la renombrada reja del presbiterio de San Juan de la Penitencia, de Toledo, ejemplar acabado de labor repujada y cincelada que acusa la suprema maestría de su antor.

Bastante recnerda a esta última la de la capilla de la Piedad en la Catedral de Segovia, obra primorosa, muy notable, tanto por su conjunto como por to acabado de sus detalles.

En 1500, el Maestro Pedro ejecutaba las de la cotpilla de San Eugenio en la Catedral de Toledo, y de este año al de 1508 aparece Finxasdo Prieto trabajando unas rejas en la Catedral de Sevilla. Entre tanto, en 1505, Pedro Rodríguez hacía una primitiva reja para el altar mayor de la Catedral hispalense; así como Antonto de Viveros construía en 1503 la del coro y la de la capilla mayor de la Catedral de Murcia, empleando barras retorcidas, arcos conopiales, cresterías flamígeras y adomos del período de transición al Renacimiento. 
Por entonces consta en el Libro de Obras de la de Barcelona (1501 a 1503, pág. 7) haber satisfecho a Pedro Riembau, herrero, la cantidad de 23 escudos por la reja del coro de la capilla de Santa Eulalia.

Labor sobresaliente de este período son las rejas de la iglesia de Guculchupe, ejecutadas desde 1510 al 1514 por Frar Fraxcrsco DE SALAMANCA y Fray JuAN DE Avila, artistas que hemos de rolver a encontrar llerando a cabo siempre notables obras, y que en éstas seguían fielmente las tradiciones nacionales, aunque en su disposición actual observe el señor Gestoso alguna alteración de la primitiva (1).

De los propios días de los Reyes Católicos es, a juzgar por los blasones y emblemas reales que ostenta, la reja de la capilla del Hospital real de Santiago de Galicia, en la que se observan ya ciertos detalles platerescos, más acentuados e importantes en la extensa del pórtico de dicho Hospital, con hermosa crestería plateresca.

Autor de las rejas del claustro nuevo de la capilla de la Concepción en la Catedral de Sigiienza fue el MaEstro Usós; obra ejecutada en 1509, que es nua mezcla de estilo gótico y plateresco con perforado friso, habiéndole sido encomendado dos años después las rejas parr las ventanas del mismo edificio, que resultan agradables a pesar de su sencillez, mediante la combinación de barras retorcidas con espacios para corazones, rematando con unas flores de carácter ojival, siendo tal vez de su mano los candelabros para la citada Catedral.

Conforme a escritura otorgada ante Alonso Paz, se comprometió JUAN Relojero, vecino de Palencia, el día 19 de Febrero de 1512, a hacer la reja de la capilla de Nuestra Señora de la Blanca, de la Catedral, en aquella ciudad, habiéndosele abonado su importe por cuenta del canónigo Bartolomé de Palencia, ascendiendo a 25.000 maravedises y carga y media de trigo.

Gulllermo Ervenat construye el anio 1517 la famosa reja del presbiterio de la Catedral de Pamplona, firmada con caracteres monacales calados en exornada cenefa, obra de las más acabadas y primorosas de este período, apreciada cual la más sobresaliente de su estilo.

Como verdadera joya de este tiempo hay que estimar la reja de la capilla de Santa Ana en la Catedral de Burgos, originalísina en sus perfiles y de una elegancia extremada, debiéndose al MLaestro Esteban las de la capilla mayor de esta Catedral, que hizo en 1523.

En el Mnseo Arqueológico Nacional se conserva la que existía en la

(1) Véase De Sevilla a Guadalupe, 1913, pág. 47. 
parroquia de Santa María, de Madrid, cedida al Museo por el Ayuntamiento, al ser derribado aquel templo en 1868; por su estilo es de época ya avanzada. Pero ofreciendo ma traza mu bella y gallardos detalles platerescos, tenemos la de la capilla de Santa Ana en la Catedral de Huesca, que según nota del Sr. D. Ricardo del Arco, fue ejecutada en 1525 por el maestro Arnau Guillén.

Fue costeada, así como toda la capilla, por el canónigo de Huesca don Martín de Santángel, y según los Libros de Fábrica (1825, folio 50 vuelto), aparece el maestro Arnau Guillén trabajando en 24 de Julio en esta reja. Desde el an̂o de 1515 estaba este artista al servicio del Cabildo, por designación del mismo. En 1516 trabajó un precioso atril de hierro para el coro, según reza el Libro de Fábrica. Consta en él que con dicho motivo se le entregaron en 31 de Mayo $4+$ sueldos, más ocho por el arreglo de otro atril, en el que se leían los Erangelios de misa de Requiem. Además cuidaba Arnau Guillén del reloj de la torre catedralicia (1).

En el siglo XV las rejas de rentanas de los alcázares, palacios y castillos llevan en la extremidad superior de los barrotes unas puntas, e inferiormente se retuercen en igual forma; las de clausura se componían de barras verticales terminadas en tres o cuatro rástagos con otras tantas hojas, que concluyen en punta, del propio modo que las flores y estambres.

De esta época de transición no se podrán presentar otras más bellas en España, sin duda, que las de la conocida Casa de las Conchas, en Salamanca: por sus originales perfiles, gracia y belleza de sus detalles, se ofrecen como las más sing'ulares de su tiempo. Debieron ser ejecutadas hacia el ańo de 1512, en que se terminó tan original palacio.

La cerrajería construye en este tiempo, en sus diversas secciones, objetos para el culto litúrgico, mobiliario, útiles de cocina y, en una palabra, cuanto pueda satisfacer las necesidades de la vida, el lujo y la seguridad o defensa; pues tal grado de perfección alcanzó, que fue considerada como complemento necesario en aquella sociedad y en ella ofreció sus más acabados ejemplares de todo género.

Aldabones.-A tanto llegó en esta época la fantasía desplegada por los artistas en estos útiles, que bien pudiera ser objeto de un estudio especial la serie de ellos en la herrajería española: dígalo el ejemplar que existió en la casa del arcediano, en Barcelona, muy notable a juzgar por las muchas imitaciones hechas, como prueba de su originalidad; el del derruído palacio de Mosén Sorrell, en Valencia; los preciosos de la colección

(1) Carta-nota del Sr. Del Arco, Cronista de Huesca. 
del Sr. Rusinol; el del archiro de Ta Corona de Aragón; los existentes en el Museo municipal de Barcelona, con otros muchos repartidos en la Península, y que formarnn el exorno más vistoso de tantas suntuosas puertas.

Con la denominación de aldabourssuele designarse generalmente al objeto colocado para llamar en las puertas, que consta al principio de una argolla sujeta a un disco calado, sobre el cual golpea, mientras que en los llcamadores es sustituída la argolla por una figura o adorno.

En cuanto a las placas rectangulares, clavos y dobles churuelas, hemos de citar las interesantes de la puerta principal de la Catedral de Tarragona, por merecer un puesto de honor en la cerrajería de este período, revelando a la vez un gusto y riqueza que constituye en esta especialidad lo más interesante de tal región.

Estas renombradas puertas, que costeó el Arzobispo D. Gonzalo Fernández de Heredia el año de 1510 , son de roble, forradas con planchas de hierro repujado, claveteadas rom boidalmente con florones de cobre.

En los clavos que exornan los centros de los rombos se observa como elemento decorativo la letra $\mathrm{T}$, inicial de 'Tarragona; segín

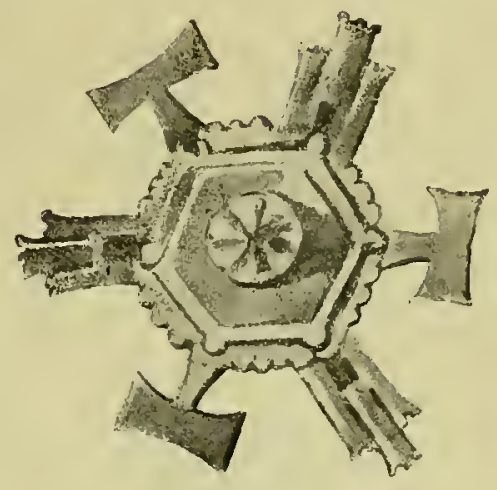

Clayo de la pnerta de Ia Catedral de Tarragona. otros la de la mártir Santa Tecla, venerada en la localidad como su Patrona. Las anchas y caladas charnelas son muy bellas, así como sus aldabones de gran anillo cincelado, que sujeta una cabeza de monstruo con su boca, sobre preciosa arandela calada. Por el estilo corresponden aún por completo al ojival más puro, tanto, que por algunos son creídos de época anterior varios de sus elementos.

Bajo la palabra herrajes se comprende cuanto puede asegurar y decorar un mueble o edificio; tal sucede, por ejemplo, con los chutones de forma aplanada como la cabeza de un clavo grande, muy usados para ornamentar sujetando a la vez los hierros, a diferencia del clrcon, que es de fecha posterior, provisto de artística cabeza de variado dibujo, con una punta para fijarle; por cierto que en este ramo de la herrería hicieron m verdadero derroche de ingenio los maestros castellanos, ofreciendo variedad de modelos inacabable, a juzgar por los que forman las colecciones particulares donde se admira esta especialidad, superando a Ios extranjeros por su carácter tan admirado. Prueba de ello las dos líminas de clayos artísticos que publicamos.

Charnelas y bistugras. - Confundidas con frecuencia ambis palabras, 
y siendo en realidad las segundas una última perfección de las primeras, fueron muy usadas como exornación de las puertas y refuerzo de las mismas al sujetarlas al bastidor, sobre todo en los siglos medios, cambiando de gusto y estilo al compás que lo verificaba la arquitectura.

Complemento de los herrajes fueron también los picaportes, tiradores o argollas para cerrar de golpe las puertas, las cerraduras, candados y llaves, que ya en este período adquieren un grado de adelanto por sus chapas caladas, grabados y cincelado, empleándose además las cerraduras de picaporte o pestillo, denominación dada por tener éste montado sobre el palastro, con un botón y una báscula.

Los grifos o seres fantásticos de la ornamentación empleáronse en palomillas, camales, grias, remates, fogones de ituminarion, saledizos, balcones, veletas y mil aplicaciones diversas por los herreros, pues la característica silueta de aquellos engendros dudosamente destacados en sobrios edificios, acentuaba el carácter de aquella férrea época de fe y superstición, ventilándose en estrechas callejuelas venganzas y rivalidades a la

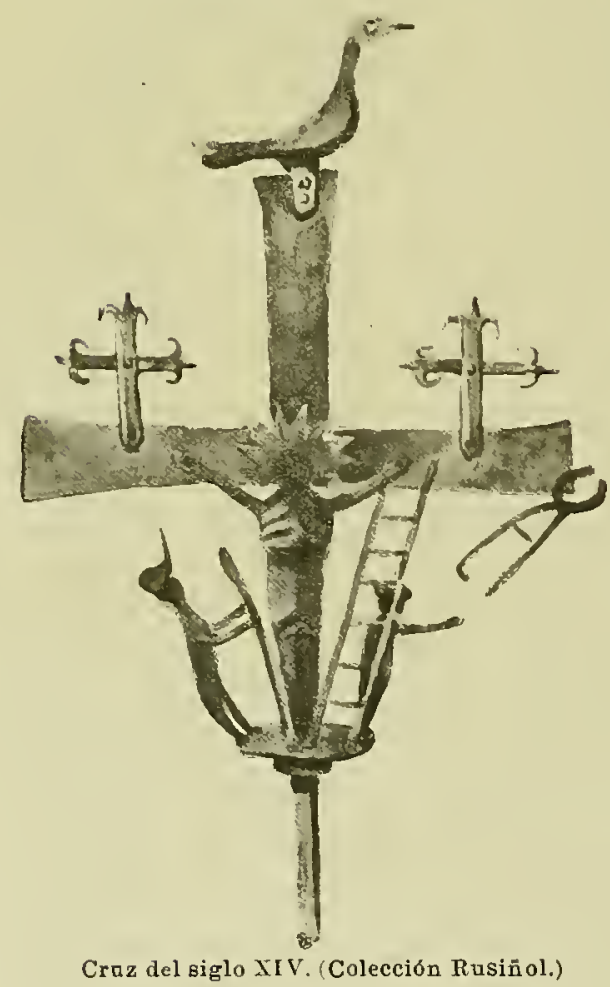
escasa luz de tenues farolillos pendientes de artísticas palomillas de hierro.

Otro ramo de la herrajería fueron las cruces de lincle, llamadas vulgarmente de término, por marcar el límite de ma jurisdicción o proximidad a un monasterio; habíalas de hierro y piedra, colocadas sobre largo fuste en una escalinata, admirándose hoy todavía algunas colocadas en los caminos o entradas de pueblos, muy abundantes en Galicia y Asturias; el grabado es un curioso ejemplar de una cruz (no de término) que existe en el Cau-Ferrat de la colección del Sr. Rusiñol, algo similar a otra interesante cruz adquirida por la Comisión de Museos de Barcelona, pudiéndose juzgar ante tales ejemplares del carácter impreso a ellas por los herreros.

Las coronas de huz continuaron empleándose, honrando esta labor a los modestos herreros, así como los candelabros, mezcla del ojival y primeros albores del Renacimiento, fueron perfeccionándose en su labor, exomándolos con escudetes, grifos, y policromándolos, sin duda para eritar por este último medio la oxidación y darles mayor riqueza. 
Los hacheros de tres luces y otros de variada forma para una sola luz, procedentes de la Catedral de León y donados por el Cabildo al Museo Arqueológico Nacional, ostentan adornos góticos: la arandela y su aspecto elegante les hace dignos de alabanza; pero de todos éstos ocupan sin duda el primer lugar los de la Catedral de Burgos, de admirable traza y ejecu-

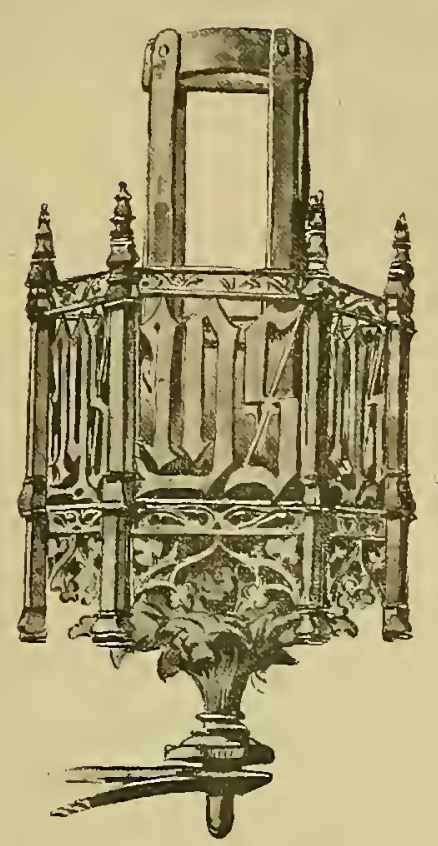
ción, delatando jor su estilo la época especial de transición a que pertenecen.

Viollet-le-Due dice que los cerrajeros de la Edad Media emplearon para dar mayor ductilidad al hier'o en trabajos delicados, claros viejos y herraduras usadas, con objeto de evitar las grietas del palastro nuevo; sin embargo de esta circunstancia, ya veremos cómo algunos afamados rejeros prefirierón el empleo del hierro nuevo, entre otros CristóBaL Axdivo, ignorándose si la cansa sería por desconocer esta propiedad $\mathrm{y}$ contingencia del hierro nuevo, lo cual no es de suponer dada su práctica y conocimientos.

Las armadrras de priso lachero de la Catedral de Burgos. también resultan bellas le líneas en unión de su artística palomilla que sostiene la polea, prestándose a decorar con arte esta disposición o conjunto según la habilidad del herrero: suelen escasear estos ejemplares, que colocaban en los patios de las iglesias, castillos y palacios, siendo más prodigadas durante los siglos XV al XVII.

En cambio, los cofrerillos, por la índole del objeto, eran de esmerada confección en cuanto al repujado, cincelado y calado; los había de hierro, pero más usuales de madera, con aplicaciones de herrajes artísticos, abrazaderas, escuadras,

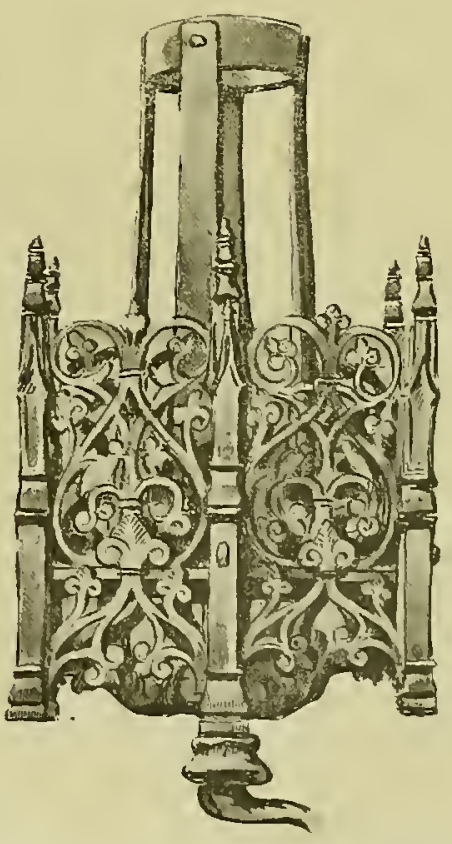

Hachero de la Catedral de Bargos. típica cerradura, dibujos calados de la época y provistos de asas, todo hecho a cincel, resultando lo que podríamos llamar ejemplares de orfebrería del hierro; estos cofres, conocidos con el nombre de ferrados, tenían el doble objeto de gnartar alhajas y de mueble artístico, que colocaban en lngar predilecto. 


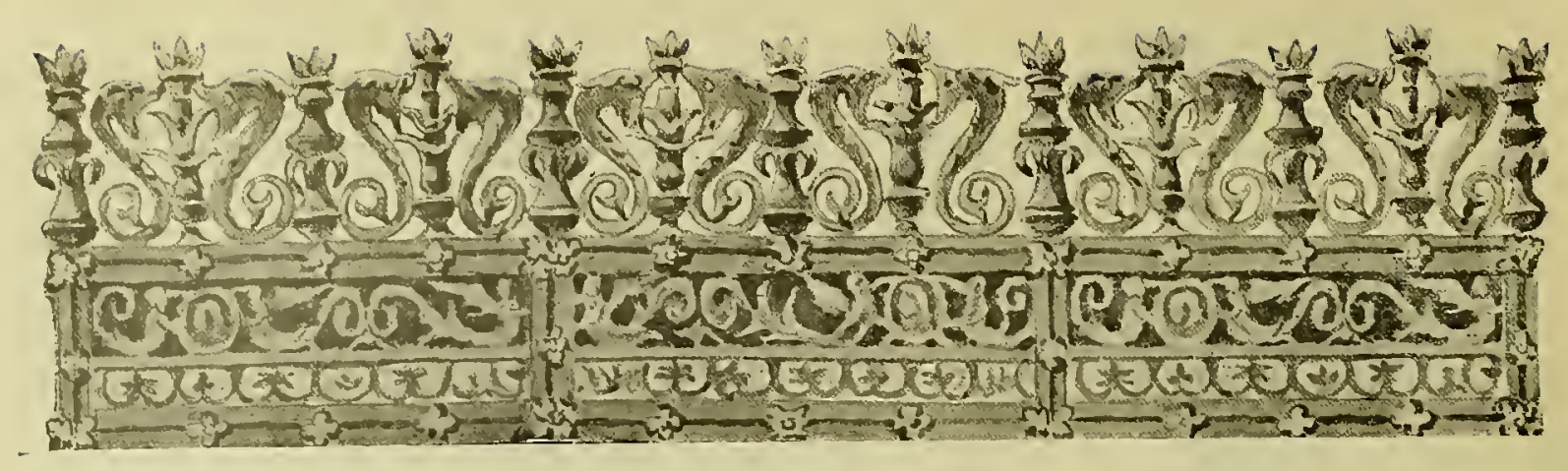

Cresteria de la reja de la Biblioteca en la Universidad de Salamanca.

\section{EPOCA TERCERA}

\section{Renacimiento.}

Sigro XV1.- I ons fases o períodos comprende: el Plateresco y el Grecoromano. Con el primero se desiguan los monumentos del Renacimiento, notables por sn delicadeza y fantasía en los relieves, inspirados en los famosos grutescos de Rafael de Urbino; aceptarlos por los plateros para la exornación de las superficies eu sus trabajos, lo practicaron a su semejanza también los rejeros, aprovechándose de ello por el partido que podían sacar para el repujado, grabado, cincelado u otras operaciones similares de aquellas obras, que llegaron hasta nosotros gracias a la resistencia del material con que fueron hechas.

La manifestación más espléndida de este nuevo gusto fue la de las famosas rejas, que entonces se ejecutaron en número extraordinario para nuestras Catedrales y grandes templos, llevadas a cabo por los maestros que mayor fama obturieron en tal arte entre nosotros, pues los nombres de Andino, Viliallando y los Vergaras, con otros tantos no menos célebres, son los que más honra recabaron para el suntuoso arte con que enorgullecen a nuestra Patria.

Las más notables rejas repartidas en la Península pertenecen en general al puro gusto platereseo, degenerando al cabo en el seco o tal vez duro greco-romano, del que poseemos bien eseasos ejemplares.

De modo satisfactorio sorprende ver que el arte del herrero pierde 
sus formas vulgares en este siglo para ascender a una jerarquía superior. llenando las superficies con delicados adolnos para aumentar el valor del objeto, mediante el cincelado, repujado, colores, grabado y dorado, no ya como industria determinada, sino cual rerdadero arte, en el que el grado de adelanto fue tan subido en los dirersos ramos de la metalistería, que constituye su período más floreciente.

Que adquirió gran preponderancia en España lo corrobora el considerable múmero de rejas elaboradas en Palencia, Toledo y otras ciudades. mientras la ferretería, en las demás regiones, era verdaderamente notable, como en Mondragón, Eibar, Albacete, Tergara, Sevilla y San Sebastián, manifestándose en cada provincia lin gran florecimiento, pues sólo en Barcelona hubo más de noventa herrerías, donde se trabajaban al año sobre 120.000 quintales de este metal labrado.

En una palabra, el arte del hierro adquirió entre nosotros con el Renacimiento su más absoluto desarrollo y su mayor valor estético.

Rejas platerescas.- Versados los maestros rejeros, especialmente los castellanos, en el dibujo, por la triple cualidad en algumos de ellos de ser plateros, escultores y arquitectos, necesariamente habían de resultar sus producciones verdaderas obras artísticas, que de no haberse ejecutado en este metal no hubieran tal vez llegado hasta nosotros, cual si se propusiesen perpetuar el trabajo por la cualidad de la materia.

Este alto nivel del arte castellano, en unión de la esmerada labor en el limado, repasado, ajuste re las piezas y repujado, fue causa de la admiración europea en este siglo y de la superioridad hasta sobre los rejeros alemanes.

Con efecto, la rejería adquirió notable desarrollo con el progreso del Renacimiento, obligando a los maestros a la perfección de la obra en virtud del gusto dominante de la época para armonizar con la arquitectura, y motivó ser el tipo de las rejas el monumental, debido a la grandiosidad de sus proporciones; asimismo aumentó el número de piezas y esmero del trabajo, lo propio en el centro y Norte re Espańa, que en el Mediodía, pues en todos lados se hallan indistintamente rejas de sin igual belleza. bastando para ello recordar las de las Catedrales de Palencia. Salamanca, Burgos, Toledo, Sigiienza, Granada y tantas otras.

Rejas del altar mayor y del coro de la Catedral de Sevilla. - La forma de la capilla mayor de la Catedral de Serilla, en lo referente a su parte arquitectónica, exigía la necesidad de colocar tres monumentales rejas que la cerrasen, como en efecto así se lleró a cabo. 
Tanto Ceán Bermúdez como otros escritores que se han ocupado de estas rejas, han incurrido en confusiones y dudas respecto a sus autores $\mathrm{y}$ fechas, lo que ha causado la consiguiente indecisión sobre el criterio que pudiera adoptarse; pero todas quedan desvanecidas gracias a los documentos del Archivo eclesiástico sevillano, estudiados y publicados por el Sr. Gestoso en su Sevilla monumental (1), por lo que renimos a conocer claramente su historia en sus puntos más interesantes.

Lo ocurrido fue, que el Cabildo acordó, en 16 de Octubre de 1517, según se consigna en el libro de Antos Capitulares, que el arcediano doctor De Reina escribiese "a un maestro que face rexas de hierro", que trabajaba en Cnenca con gran crédito, y que se llamaba SANCHO MuÑoz, para que se encargara de la hechura de las rejas del coro y altar mayor de la Catedral sevillamu.

Así lo hizo, y poco después de presentado éste, se personó también Fray Francisco de Salamanca, al que ya hemos visto ejecutando las rejas de Guadalupe, amn cuando no consta si fue llamado; pero el resultado fue que les pidiernn a ambos dibujos de las rejas, con objeto de poder elegir el Cabildo, con inclusión del precio y tiempo de duración de la obra.

A fines del an̂o 1518 resolvióse en definitiva que hiciera SAncho MuÑoz las rejas laterales del altar mayor, forjadas, disponiendo fuesen de hierro de Vizcaya, de acuerdo con las trazas presentadas, y a Fray Francisco de Salamanca le encargaron la del coro, forjándose ésta en una dependencia próxima «al corral dentro de San Miguel», mientras que la del altar mayor se construía en un local del Alcázar, previo pago de una cantidad en concepto de renta, según aparece en el Libro de Fábrica del año 1520.

Sancho Muñoz trazó y diseñó las dos rejas laterales de la capilla mayor, y no la del coro, como equirocadamente dice Ceán, empezando su labor por la del lado de la Epístola, que la forjaba en el Alcázar, con la compañía de JuAx Yepes y el Maestro Estebax, habiendo aceptado las condiciones propnestas por el arcediano de que se la admitiera "siempre que la terminase y dorase al an̂o y medio, comprometiéndose a entregarle 200 ducados de oro cada año, pero con la condición precisa de no percibir cantidad alguna si excedía del indicado plazo".

No parece que quedaran muy cordialmente establecidas las relaciones entre Muńoz y el Cabildo, por lo que comenzó exponiendo la necesidad de marchar a Cuenca por oficiales que le ayudasen; pero habiendo presentado las trazas $y$ sido aprobadas, rolvió para empezar la obra

(1) Tomo II, ๆảg. 213. 
en 1519, ayudado de los dichos, con los yue pudo finalizar, para el plazo convenido, una de las dos rejas laterales, la del lado de la Epístola, apareciendo pagada en los Libros de Fábrica del 1520.

Una vez entregada debió marchar a su tierra, pues después de este último año consignado no se vuelve a luacer mención alguna en los documentos sevillanos de este maestro rejero. Entre tanto Fray Francisco de Salamanca trabajaba en la suya del coro.

Ausente Munoz, había necesidad de que se continuara la ejecución de las rejas del presbiterio, por lo que quedó encargado DIEgo de Udobro y JUAN dE Contllaxa de ejecutar la otra lateral del Evangelio, compañera de la ya terminada, por la que satisfizo el Cabildo, en 1522, la cantidad de un cuento e 240.500 maravedís (1) que ovo de aver por las dos rexas que hizo a los lados del altar mayor, abonándole además 1.500 maravedís por demasías de forja.

Como se ve, ejecutó por completo la verja del lado de la Epístola, y quizá hubo de hacer algo en la de Sancho MLû́oz, según el asiento, ayudado de Juan Cornillana, así como del MLaestro Bartoloné, al que encontramos con este motivo en Sevilla y del que tendremos que ocuparnos en breve al tratar cle otra obra notabilísima.

Por su parte Fray Francisco de Salamanca entregaba la del coro en 1523.

Faltaba por hacer la central del presbiterio, frontera al altar mayor, por lo que el Cabildo, en 9 cle Octubre de 1523, acorcló «que el arcediano De Reina tomase un escribano para escribir a todos los que facen rexas en Castilla, si quisieren entender en la rexa, e cada uno traiga la de muestra de las rexas que ha fecho".

Presentáronlas, como era natural, Udobro y el Maestro Bartolomé; pero el Cabildo, a quien, por lo que se re, agradaba sobre todo la labor de Fray Francisco, llamóle expresamente para que volviera de Valladolid, adonde se hallaba (2), para encargarse de la ejecución de la reja central del presbiterio, que no acabó hasta el año 1529.

De estas rejas, por lo tanto, la primera terminada fue la lateral de la Epístola en el presbiterio, ejecutada por Sancho Muîoz, que al trazarla adoptó para ella el gusto del Renacimiento, resultando la obra verdaderamente hermosa, y dando, por sus proporciones y detalles, la pauta para las restantes.

(1) 1.240.500 maravedís equivalían en su tiempo a la cantidad de 3.544 escudos de oro.

(2) Consérvase la partida correspondiente a los gastos de viaje del peón que se envió a Valladolid con tal objeto. 
Alcanza ocho metros de altura, formada por dos cuerpos de balaustres separados por anchos frisos calados con sus grandes molduras, sostenidas por cuatro órdenes re pilastrones con capiteles, que rematan en airosos flameros. Los dos anchos frisos los decoran valientes fantasías caladas, del Renacimiento, coronándola alta crestería con gallardo dibujo plateresco. Todas sus pilastras y molduras están prolijamente cinceladas, apareciendo en toda su exteusión fuertemente dorada. En su total aspecto aún tiene cierto acento castizo medioeval que le da singular carácter.

La del lado del Erangelio, ejecutada por Udobro, ó Idobro, viene a ser como una repetición de su compañera, aunque ofreciendo un carácter más marcadamente italiano en sus perfiles.

También es admirable la del coro, ejecutada, como hemos visto, por Fray Francisco de Salamanca, y no de Zalamea, como le llama Ponz. Era este religioso lego de la Orden de Santo Domingo habilísimo rejero, reconociéndole de tal modo el Cabildo sevillano esta cualidad, que al presentarse le encargó, como hemos visto, la ejecución de la reja del coro, en la que trabajó durante cuatro ańos, ayudado por Fray Juan de Avila, entregándola en el de 1522.

Consta de dos cuerpos formados con barrotes sostenidos por un zócalo, sobre el que se levantan seis pilastras con capiteles, cuajadas de adornos en sus cuatro caras, que dejan cinco espacios en sentido vertical: dos menores laterales y el central, apoyándose en ellas 1 in friso con ornatos platerescos, armonizando con los anteriores, de correcto dibujo; queda dividido este friso en cinco espacios por artísticos balaustres llenos de tallos y hojas, destacándose en cada espacio un círculo, dentro del cual hay la imagen de un santo rodeado de follajes, y sobre la cornisa se apoya la crestería, compuesta de roleos a guisa de voluta, abrazando flameros, adornos quiméricos y tallos, con campaniles a los extremos, ostentando en el centro la alegoría de "La Generación temporal de Cristo", formada por patriarcas y personajes bíblicos: sobre todos se destaca en el centro ma preciosa imagen de la Virgen con el Niño.

Con motivo de la catástrofe ocmrida el $1 .^{\circ}$ de Agosto de 1888, que arruinó parte del edificio, fue destrozada esta joya; pero hoy afortunadamente se halla por completo reconstruída.

La mayor en tamaño de estas rejas es la del lado del Poniente, o sea la del centro del presbiterio, que tiene seis cuerpos de altura, con inclusión del zócalo y ático, siendo mo de los trabajos de rejería más acabados que pueden ofrecerse (1).

(1) Véase Gestoso, Sevilla monumental, II, pág. 222. 
Del zócalo elévanse los barrotes, que sostienen una fuerte moldura sobre la que apoyan los del tercer cuerpo, ostentando un círculo en el centro, donde se destaca la cabeza radiada del Salvador, y encima preciosos adornos de la época, repujados en chapa de hierro, figuras de profetas o santos y un artístico friso, donde la quimérica imaginación del autor ideó preciosas combinaciones de correcto dibujo, destacándose en la parte superior la composición del "Entierro de Cristo», repujado con valentía, formando el todo un armónico conjunto, limitado por flameros que seccionan la monumental crestería admirada de todos. Por su estilo pueden estimarse estas rejas como las que primeramente ostentan en todo el italiano, aunque no falte en sus detalles cierto acento aún castizo que les presta singular carácter.

No con esto terminó en Sevilla la Iabor de Fray Francisco de Salamanca, pues comprendiendo el Cabildo que faltaban en aquel frente púlpitos que correspondieran a tanta suntuosidad, acorló se hiciesen otros, «los más ricos y decentes que ser pudiesen», encomendando el encargo al ilnstre rejero dominico.

No correspondieron, en verdad, ma rez terminados, a tales propósitos. Cansado sin duda Fray Francisco, faltóle inspiración para su nuevo encargo; pero aun así, como los terminó, no carecen de mérito suficiente para figurar al lado de la reja.

Mnstró sus frentes con placas en relieve repujadas; el del lado de la Epístola con pasajes de la vida de San Pablo, notables por su ejecución e indumentaria, así como los cuatro Evangelistas en el correspondiente al lado del Evangelio, dando por terminados ambos púlpitos en los comienzos del año 1532.

Estas bellas obras, sostenida cada ma por columna de hierro exornada en armonía con la reja del altar mayor, manifiesta el Sr. Gestoso, ocupándose de la cuenta del dorado de los púlpitos, "fue satisfecha al año siguiente, entregando a Diego Gumiel 70.000 maravedís por 2.000 panes de oro, y 14.865 maravedís a Juan Arias por 4.200 panes de oro, pues fueron dorados en su totalidad, igualmente que las rejas».

En Cabildo de 13 de Agosto de 1533 se dió cuenta de ma.instancia de Fray Francisco de Salamanca por la que pedía se le otorgara licencia para se $i^{r}$ a su tierra, la que se le otorgó, remunerándole además generosamente.

En cuanto a Fray Juan de Avila, rejero lego religioso de la Orden de San Jerónimo, aparece haber trabajado el ańo 1512, en compańía de Salamanca, en la reja divisoria del crucero de la iglesia en el monasterio de Guadalupe, de la que hemos hecho la mención debida. 
Lo propio sucedió también en la construcción de la reja del coro que sustituyó a la antigua, según se deduce de este párrafo: "se me an de rescibir en cuenta 23.121 maravedís de 66 quintales e una arroba e cinco libras de hierro que rescibió Frey Juan, compañero de Frey Francisco, de las barras de hierro de la rexa vieja».

La Catedral de Sevilla contiene otras varias, verdaderamente notables, en sus capillas, de las que sin duda obtiene primer lugar la de la llamada del Almirante. Obra de los maestros (1) Pedro Delgado y Cosme. DE Soribas o Sorriba, de la que pagaba, en 25 de Mayo de 1562, la cantidad de 11.250 maravedís a cuenta de ella, es, según Gestoso (2), "una de las mejores del templo, pues remata con el asunto del "Enterramiento de Cristo», y todas las figuras están muy bien trabajadas a martillo».

Por la gallardía de sus líneas, del más puro Renacimiento, es, sin duda, de las más valientes de aquel templo. También sọ muy notables la de la capilla de la Gamba, obra de JuAN Méndez, ejecutada en 1554; la pequeña de la Antigua; las laterales del coro, y otras más modernas de que daremos cuenta. PEDRo DE ANDrNo, padre del célebre Cristóbal, construyó, según Ceán, una reja para la libreria de la Catedral sevillana, en 1527, pero actualmente no existe, ni se sabe en qué lugar fue colocada.

Otrois rejeros sevildanos. - Indudablemente debieron formarse otros metalarios en Sevilla al trabajar al lado de maestros tan consumados, figrurando en esa cindad, hacia el año 1534, los cerrajeros Antonio Pineda, Juan Mexía, Andrés Morales, Hernando Alonso, el reedor Andrés MuNoz, elegido algunos ah̆os después en el mes de Diciembre, y Bartoloné DE RoBles, que hizo cerraduras con llaves taladradas y variedad de herrajes destinados al Alcázar de Sevilla en 1575.

Por este tiempo construyó Antonio Xrmenez unas rejas para el edificio de la Alhóndiga sevillana, con objeto de cerrar los arcos bajos de la galería que años anteriores unían a las Casas Consistoriales; y previo acnerdo, en 1537, el Cabildo de la Catedral de Sevilla encargó a Pedro Delgado, rejero, una verja para resguardar el sepulcro del Cardenal Cervantes. BartolouÉ Morel, rejero, padre del fundidor sevillano de igual nombre y apellido, que construyó el famoso tenebrario, hizo unos hierros para las campanas de la Giralda, las cuatro bolas con azucenas de las esquinas y otros trabajos ajenos a nuestro propósito; colaboró con JUAN BAUTISTA DE Valencia, Juan Fernández López y Francisco López en las cuatro rejas para la sala de fiestas del Alcaizar de Sevilla, en virtud de documento de

(1) Véase Gestoso: Sevilla monumental, t. II, pág. 367.

(2) Apéndices al Diccionario de Artifices, t. III, pág. 437. 
compromiso no fechado, pero firmado, notándose aparece JuAn LóPEz DE Toledo en lugar de Juan Fernández López, sin explicarse la causa a que pudiera obedecer esto.

Entre otros de los particulares consignados, figura el precio de dos reales y cuartillo para la libra de hierro labrado, siendo de su cuenta la merma del material recibido y aumento por el exceso de trabajo en el friso, repujado, cincelado y labrado de las dos caras.

Hizo en 1542 otra reja de las cuatro que había para la sala grande de las bóvedas del citado Alcázar, e intervino también en la notable obra del facistol del coro de la Catedral de Sevilla, hacia el año 1590.

Antonio De Clenca construyó la verja del pabellón de Nuestra Señora de la Antigua en la capilla de la Catedral de Sevilla, por la que percibió 180 maravedís, e hizo también la farola de la Nao capitana de Arias Dávila, cuando marchó a la América Central (1514), según manifiesta don Manuel de la Puente, y en $1 .^{\circ}$ de Abril del mismo año consta que al rejero JuAN DE Cuenca, pariente tal rez de Antonio, le fue abonado el importe de la reja para una de las ventanas de la sala de San Jorge en el Alcázar de Sevilla, que pesó once arrobas y catorce libras, a razón de 15 maravedís la libra, como del propio modo, en igual fecha, Drego de Cuenca construyó otra reja de ventana con destino al comedor del cuarto real sobre la tribuna de la sala de fiestas.

Rejero y escultor granadino fue JUAN López, que, mediante escritura otorgada en Sevilla el an̂o 1565 ante el notario Domingo Ramos, se comprometió a hacer la reja grande para la capilla de Nuestra Señora de la Antigua en la Catedral de Sevilla, pues si bien es cierto que liabía una reja en el mismo lugar hecha en 1533 por Francisco de Salamanca, se acordo quitarla a causa de ser pequen̂a, llenando la actual el hueco completo del arco, conforme la traza de Fernan Ruiz, maestro mayor de la fábrica de aquella Catedral. Resulta de grato aspecto, en especial la parte alta, que está cuajada de adoruos y figuras de estilo plateresco, siendo también de su mano la reja de bronce del altar de la Virgen en la capilla de la Catedral de Toledo, hecha el año 1564, y otra que se ignora la iglesia donde se colocó en esa ciudad, terminada en 1554.

En el siguiente año Rodrigo de SEgovia trabajaba en la reja central de la capilla la Antigua, en Sevilla, lo que indica haber hecho en aquella obra algún trabajo secundario; asi como Antonio del Valle la reja d. claraboya y antepechos del mismo edificio en 1590.

Citando el Sr. (iestoso al rejero Francrsco López, dice, hizo mos balcones con airosos balaustres de hierro torneado. sostenidos por tres drago- 
nes alados del mismo metal, el año 1592, apareciendo en las cuentas varias partidas de chapas y hierros entregados, que suman un total de 514 arrobas, suponiendo, en virtud del estilo del Alcázar sevillano, habría de tener ajímeces donde se colocasen los balcones, probablemente en el Salón de Embajadores y Torre del Alcaide, trabajando además en las rejas de las ventanas de la Sala de Fiestas, en 1586, e hizo dos lampareros de hierro y bronce para la capilla, y dos balcones del Salón de Embajadores, como otras obras de escasa importancia, según este escritor-arqueólogo consigna en la página 365 del tomo primero de su interesante obra de investigación, Sevilla monumental.

También estuvieron ocupados en similar labor en este palacio el año 1592 Juan Pineda y Juax López Toledano, construyendo éste unas ventanas de la Sala de Fiestas.

Rejas de la llamada Casa de Pilatos. - Entre las bellezas artísticas. que atesora este singular palacio sevillano, no son las menos importantes sus rejas de hierro repujadas y cinceladas, del más puro y gallardo estilo del Renacimiento.

De autor completamente desconocido, pues ni el Sr. Gestoso en su Sevilla monumental, ni ningún otro que sepamos lo determinan, debieron ser ejecutadas por alguno de los más sobresalientes señalados (quizá Pedro Delgado, el que ejecutó la mayor parte de la que cierra la capilla del Mariscal, citada) ya bien entrado el siglo XVI, pues por su estilo corresponden al más suntuoso del Renacimiento, de lo que es buena prueba la famosa reja de ventana que reproducimos, tan admirada de todos y reconocida como el más sobresaliente ejemplar de su género con que contamos.

Las otras rejas o cancelas del palacio no ceden en belleza de estilo a la pintoresca ventana.

REJAS en GRANAdA.-En la región andaluza se encuentra también una de las obras más notables de la rejería española, cual es la de la capilla Real de Grancuda, reputada, con razón, cual verdadera maravilla de la labòr artística del hielro.

Fue su autor aquel Maestro Bartolomé que hemos visto tomando parte en el concurso de la reja central para la Catedral de Sevilla, y posible fuera que aprovechase para la de Granada algo de la traza de aquel proyecto. Ceán Bermúdez dice, al ocuparse de él, que era escultor, lo que no es extraño, dada la abundancia de figuras humanas que introdujo en sus obras de rejería. 
Llegó a Sevilla en 1523, procedente de Jaén, donde debió ejecutar una obra de que daremos cuenta, pasando después a Granada para llevar a cabo la admirable reja de la capilla Real que citamos.

Pues bien, aun cuando por los documentos examinados en el Archivo de Simancas por D. Patricio Ferrer, publicados en la Revista de Archivos, Bibliotecas y Mluseos, consta se comprometieron a ejecutar la reja de la capilla Real de Granada, Juax Zagala y Juan de Cubillana, artilleros (1), apesar de ello, repetimos, es lo cierto que los dos antedichos rejeros no hicieron la obra, sino que fué labrada por el Maestro Bartolomé, aun cuando otra cosa parezca del documento firmado en Zaragoza a 20 de Octubre de 1518, otorgado ante D. Antonio Fonseca, Contador mayor de Castilla, en nombre de Sus Altezas.

¿Oberlecía esto a incumplimiento del contrato?

¿Quién sabe si, a semejanza de lo que acontece en nuestros tiempos, el que presupuesta la obra a precio más reducido es preferido, y ocurriría esta circunstancia en el caso actual!

Sólo recordaremos que el Maestro Bartolomé presentó un Memorial para el cobro de 1.600 ducados, precio ajustado de la citada reja, además de habérsele abonado las mejoras hechas, documento que tuvo necesidad de exhibir por no haberle sido satisfecho su importe.

En apoyo nuestro diremos que indudablemente sería la causa de no ejecutar la obra los rejeros Zagala y Cubillana, el excesivo precio, pues consta «había de ser de fierro labrada... dentro de un año y medio... se les haya de dar por todo ello dos mill é ochocientos é cuarenta ducados de oro», o sea doble cantidad que la exigida por el Maestro Bartolomé.

Esta portentosa obra, con cuya firma quisieran honrarse muchos de nuestros plateros, aun cuando el ingrato metal carezca del valor y ductilidad de los llamarlos preciosos, es verdaderamente una hermosa joya del arte español, vanagloriándose Granada en ostentarla en la capilla real.

Compónese de tres cuerpos horizontales, que disminuyen de altura cuanto son más superiores: el primero consta de unos barrotes cuadrados que degeneran alternados hacia su mitad en un rombo que constituye un floroncillo, y los que carecen de él llevan un nudo aprisionando el caprichoso ornato, resultando de esta forma un bello calado en sentido horizontal de gran efecto.

Seis pilastras (tres a cada lado) cubiertas de menuda exornación, con

(1) Sinónimo de artífice en la antigüedad: citando la Revista de Archivos un manuscrito del siglo XIV a propósito de esta palabra, donde se lee artilleros herreros, o sea artífices que trabajaban en hierro. 
sus correspondientes capiteles, sostienen el friso repujado, en el que se ven bustos y preciosas labores, alzíndose sobre él el segundo cuerpo; éste le forman barrotes retorcidos, alternando en cada uno un bien combinado adorno, y enriquecidas las elegantes pilastras, colocadas perpendicularmente sobre las inferiores, con figuras de correcto dibujo, siendo la sobrepuerta una verdadera filigrana de hierro, formada por el grupo del águila que sostiene el blasón de España de los Reyes Católicos y debajo un león a cada lado, entre los que surgen roleos y finísimos vástagos para sostener los dos escudos laterales, donde campean el yugo y las flechas, cuya labor es más para admirada que para ser descrita.

Sobre ancha cornisa elévanse otros seis retorcidos barrotes constitutivos del tercer cuerpo, adornala la parte central de los balaustres en armonía con los inferiores; sus bajas pilastras cubiertas de adorno presentan estatuítas de gran pureza de ejecución adosadas a aquéllas, las que sirven de sostén a la monumental crestería o remate con diez escenas de la Pasión, cuyas figuras, recortadas, forman el tema principal de tan peregrina decoración: sobre estos compartimentos corre un sutil encaje férreo admirablemente labrado, que resulta de bellísimo efecto también por el nérito del repujado, según se observal en la fotografía que acompañamos. Un crucifijo entre San .Juan y la Virgen coronan tan hermoso conjunto.

Ya decíamos que el Maestro Bartolomé se trasladó de Jaén a Sevilla, lo que indica que debía de haber trabajado en aquella ciudad alguna obra importante, $r$ en efecto, aunque no documentada, existe en Jaén la reja de la santa capilla de San Andrés, que por el estilo de la época, abundancia de figuras repujadas y demás caracteres, bien pudiera atribuirse al insigne rejero-escultor de que nos ocupamos.

Aún de la Catedral e iglesias de Córdoba y otros pueblos de Andalucía, podríamos mencionar obras notables de la rejería en tal región.

Rejas ex Toledo.- Otro de los centros donde se desarrolló pujante la artística labor del hierro, como no podía menos de ocurrix, fué en la histórica Toledo, por tantos títulos insigue en sus monumentos. Entre ellos ocupa primer lugar la Catedral famosa, compendio de las mayores riquezas artísticas, la que deseando también ostentarlas en el arte del hierro, convocó su Cabildo a un concurso en 1539 , a fin de que los rejeros más afamados presentaran trazas para la construcción de las rejas del coro y capilla mayor, los que en 1540 las ofrecieron al Cardenal Tavera, contándose entre ellos a Francisco de Villalpando, Maestre Domingo de Céspedes, Cristóbal Axdino y Fernando Bravo. 
El primero era arquitecto, escultor y rejero, vecino de Valladolid, profesor muy acreditado en Castilla, quien presentó en igual fecha que Andino (18 de Junio de 1540) su traza en Tolerlo para la reja del coro, y al preguntarle los sen̆ores del jurado sobre si era o no conveniente hacer la reja de metal o hierro, contestó Villalpando "sería más estimado de hierro el trabajo, pues de metal habian de ser vaciados los adornos, a la vez que es material quebradizo y no se puede componer con la facilidar. que el hierro».

Añadió que podría resultar muy bien en hierro labrado con toda perfección, como también de buen efecto estando dorada y plateada a fuego, siempre que se le facilitasen estos dos metales, y que el importe ascendería a ocho mil ducados de oro. comprometiéndose a terminar la reja en tres años.

Indeciso debió estar Villalpando en presentar los proyectos de las dos rejas, toda vez que hasta el siguiente día no ofreció la proposición para la capilla mayor, al manifestar "hará la rexa de la capilla mayor conforme a la muestra que presente estaba, la cual dió maestre domingo por seys myll ducados a toda costa, dándole el oro y plata que fuera menester... con todas las mejoras que en la dha traça se hiciese dentro de tres años... e asimismo dixo que hara de hierro la Rexa del coro conforme a la muestra que presente estaba, la qual dió al dho maestre domingo por cinco myll ducados, dándole el oro y plata que fuere menester, siendo a su cargo hazer las dhas Rexas en quatro años (firma) Franciseo de Villalpando».

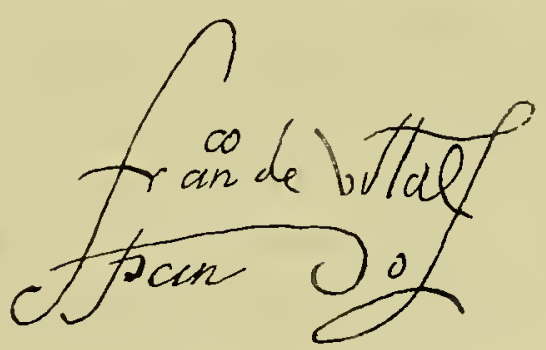

Su contricante Maestro Domingo de Céspedes, que hizo en 1523 las rejas de la capilla de los Reyes Nuevos en la Catedral toledana, presentó el mismo día 18 de Junio de 1540 un documento para tomar parte en tan celebrado concurso, "mostrando dos traças, la rna dellas para la Rexa de la capilla mayor y otra para el Choro, y paresció por la maestria de la Rexa de la capilla mayor que haciendo mas Rica la obra de los Remates, friso y cornisa... fuele dho si las dos dhs Rexas serian mejor de metal que no de hierro, dixo el maestre domingo que serian muy mejores de hierro porque an de vr doradas y plateadas a fuego y la obra que en. el cho hierro se hiciese siendo bien labrada y de buena mańa se terna en. mucho, y no estando al agua ni debaxo de tierra será perpetuo y no peligro de quebrar... por q'l metal es vedrioso... y de ello no se pueden hacer cosas tan sólidas como el hierro... q'hará la rexa de la capilla mayor de 
hierro, y con seys mill ducados, daudole el oro y la plata que fuere menester e dandole las dos Rexas las hará en cinco an̆os... m. ${ }^{\circ} \mathrm{D} .^{\circ} \mathrm{mo}$.

En 18 de Junio de 1540 entregó también al Cardenal Tavera, Cristóbal de Andino, rejero muy acreditado por las obras que había ejecutado en Burgos, nna muestra de reja para la capilla mayor,

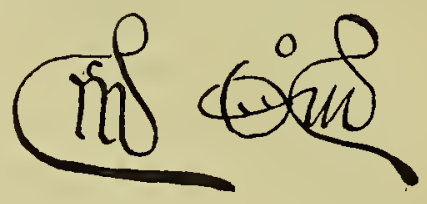
«que pareció bien según el reparto de hierros, no impidiendo ver al través dellos las sillas de coro, poniendo en los gruesos de los pilares o balaustres su Razon para que conforme con el alto cada cosa quede en la perfeccion que conviene...»

Al preguntar a Andino su opinión sobre la conveniencia de hacer o no la reja de hierro o de metal, dijo «el dho andino ser en mucha más cantidad labrada en metal que no en hierro, porque la lavor y obra que se haze en metal es de mas perficion é muy más durable arnque de mucha más costa por ser el metal de laton que se mezcla con cobre, estaño y otra confacion q'l hier'ro, y siendo dorado y plateado a fuego no ay Reparo en el limpiar de la Rexa porque la dificultad que tiene es no siendo dorado ny plateado que se a de limpiar en cada año una vez y de hierro no conviene por no sufrir en sí la perficion de lavor q'l metal ny es durable... y para semejante lugar la dha Rexa deve ser hecha de metal, por la gran estimacion que tiene, y no de hierro q's cosa comun... dho andino se ofrece a la hazer por diez mil ducados (firma) andino.»

Dos días después manifestó que haría la reja de la capilla mayor de la mencionada Catedral en la cantidad de 55.000 ducados, entregándole el oro y plata suficientes para dorarla y platearla a fuego, aumentando el adorno y perfeccionando la traza presentada.

Todos ellos, además, presentaron obras acabadas según su estilo, y con ellos pasó Covarrubias a Madrid a presentar al Cardenal las muestras que habían hecho (1).

Dicho está que Villalpando se comprometió a ejecutar la reja de la capilla mayor y Céspedes la del coro, en la Catedral de Toledo, pero deficientes debieron ser los proyectos o trazas presentados, apesar de la oompetencia de los concursantes, a juzgar por las reformas tan notables que el jurado exigía, cuanto que reunidos el día 4 de Agosto de 1540 en Ja Catedral primada los canónigos y visitadores de ella, en presencia del

(1) Datos documentales inéditos para la historia del arte español.-Notas del Archivo dc la Catedral de Toledo, redactadas sistemáticamente en el siglo XVIII por el Canónigo obrero D. Francisco Pérez Sedano, publicado por la Junta de Ampliaciones de Estudios. Madrid, 1914, páginas 48 y 66 . 
vicario D. Diego López de Ayala, se procedió al examen de las condiciones, trazas y muestras presentadas, labradas en hierro y metal por Andino, Villalpando y Céspedes, en virtud de la convocatoria del senor Cardenal Arzobispo de la diócesis, a juzgar por el contenido de estos párrafos:

«...Conviniendo que la reja de la capilla mayor había de ser de distinto dibujo y composición a la reja del coro, con la obligación de poner seis pilares en cuadrado en el primer cuerpo de la reja, según la muestra hecha por Andino, pero más esbeltos, disminuyendo dos dedos de grueso con objeto de ver mejor el altar mayor".

"...El segundo cuerpo había de tener los pilares redondos con basas y capiteles de hierro macizo en más elevación, de medio relieve, labrado a cincel, y los balaustres intermedios de menor diámetro también habían de estar tallados a cincel».

I si faltas tan grandes hubo, según dictamen del jurado calificador, aumentan de punto al saber que resultaban escasos o pobres de adorno los balaustres para una obra de la categoría que deseaban, llegando hasta el caso de indicar las mejoras y expresar que omitieron un friso sus antores, según se ve en los siguientes renglones:

"...ha de haber un friso para separar el primero del segundo cuerpo de la reja, labrado a dos caras, con talla en reliere, molduras, medallones y grutescos, porque de esta manera se lıubiera dividido la altura de la reja con arte, colocando en la puerta parte superior su arquitrave, friso, cornisa, medias figuras y pilastrones con sus resaltos de hierro macizo y no de chapa... con un remate encima de los pilares de un candelabro labrado de talla y molduras de hierro macizo y en medio de éstos en el eje de la reja un crucifijo labrado con molduras, medias figuras y grutescos, haciendo el repartimiento general de la crestería en dibujos o modelos al tamaño antes de empezar a labrarlo a satisfacción del visitador maestro de la obra».

Por la simple lectura de este acuerdo se comprende que debieron ser defectuosos los proyectos, pues bien claramente se especifican las abundantes deficiencias que habían de subsanarse, a cuyo efecto nuestro particular amigo y compan̂ero D. José Martí y Monsó, en su notable trabajo de investigación, manifiesta que en vista de las anteriores condiciones para la ejecución de la reja de la capilla mayor y del coro, declaró Andino el día 7 de Agosto, o sea tres días después, que haría la mencionada reja del coro conforme con las anteriores condiciones, o mejor dicho modificaciones, por el precio de 10.000 ducados (de oro, se entiende), "que suman tres quentos e setecientos e cincuenta myll maravedises, on tiempo de cinco 
años, y que será su comienço el primer dia de henero del año venidero... la qual hará en la ciudad de burgos, con que la obra de la dha santa iglesia la mande traer de dha ciudad a su costa y traida se le dé lugar

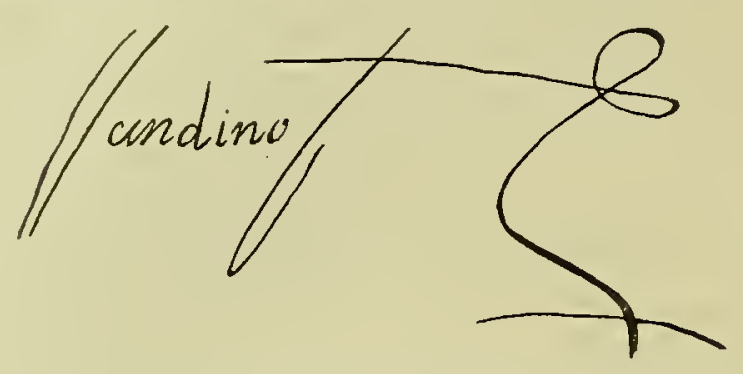
donde concierte $y$ ensable la dha rexa (firma) andino».

Y del propio modo, en igual fecha, Villalpando manifestó: «que haría la rexa por precio de tres quentos e setecientos e cincuenta myll maravedises, hecha en Valla-

dolid, pero en un año menos que andino o sea en quatro", exponiendo sn conformidad el Maestro Domingo, a semejanza de sus compañeros, en cuanto al tiempo y precio, pero que debía hacer la reja en Toledo, firmando, además de Domingo, otro rejero llamado Heruando Bravo.

Varios debieron ser los acnerdos u opiniones entre el triunvirato de maestros rejeros; las modificaciones y sitio donde se había de ejecutar la obra, así como cuanto sobre el particular indudablemente liabía de ocurrírsele al jurado calificador, puesto que debiéndose de construir las rejas en Toledo, tendrían que facilitar local y casa para los forasteros, segúu así lo acordó el Cabildo; pero en definitiva se resolvió el 6 de Diciembre de 1540, que siendo del mayor agrado de D. Juan Tarera, Cardenal Arzobispo Primado, las trazas de Francisco Villalpando, encomendárasele la construcción de la reja de la capilla mayor, bajo las condiciones desiguadas por Alonso de Corarrubias, entonces maestro de la santa Catedral, siendo entre otras de las principales cláusulas, la de que volviese a hacer nuevas muestras de pilares y balaustres, por no considerar los presentados conforme al precio pedido, en virtud de su sencillez; otra, que debían colocarse de los seis pilares, dos próximos a los púlpitos, para formar éstos y la reja un conjunto armónico, siendo de hierro sin mezcla de otro metal, pero dorada y plateada a fuego. Según los apuntes de Pérez Sedano (1), alcanzó su importe 7.000 ducados, mil por mejoras, dándola por concluída en 1548, ganando los oficiales que en ella trabajaron, según Ceán, dos reales y medio de jornal y los más hábiles cuatro reales (2).

Se compone tan preciosa obra de dos cuerpos separados por $11 n$

(1) Datos documentales inéditos para la historia del arte español.-Notas del Archivo de la Catedral de Toledo, redactadas sistemáticamente en el siglo XVIII por el Canónigo obrero D. Francisco Pérez Sedano, publicado por la Junta de Ampliaciones de Estudios. Madrid, 1914, p'áginas 48 y 66 .

(2) Téngase en cuenta que los reales de plata de entonces equivalían poco más o menos a nuestra peseta. 
friso. El primero le forman seis grandes columnas áticas exornadas de caprichosos bajorrelieves, rematando por cariátides de bronce y entre ellas los gruesos balaustres; el segundo cuerpo se halla compuesto por seis ele-gantes columnas abalaustradas, sobre las cuales se apoya un friso adornado con cabecitas, figurillas de ángeles, bichas y multitud de relieves de delicada labor donde se consigna la fecha-Kalendas, Aprilis, 1548-, y encima del cornisamento se ven airosos flameros, escudos compuestos admirablemente, sobresaliendo en el centro las armas imperiales y un crucifijo de colosales dimensiones pendiente de gruesa cadena.

Villalpando obligóse a entregarla concluída el año 1548, como en efecto así lo hizo, a satisfacción del Cabildo, diciendo Méndez Silva que de haberse forjado de líquirla plata no hubiera sido de mayor autoridad: mide 46 pies de ancho por 21 de elevación.

El haber hecho obra tan notable, fué causa de encargarle los dos puilpitos de bronce, dorados y plateados a fuego, habiéndole abonado 21.528 reales, sin incluir el bronce, siendo dignos de elogio por la esmerada corrección del dibujo y caprichosa composición, aun cuando Ponz asegura no fueron trazados de su mano, pero esta afirmación será tal vez por ignorar o pasar inadvertida la triple cualidad artística de Villalpando, haciéndonos recordar a este propósito los preciosos bajorrelieves en bronce que cubren las puertas de la fachada de Los Leones en la Catedral de Toledo, atribuídos a Berruguete, siendo así que consta de un modo indubitable los hizo Villalpando, ayudado por su hermano político Ruiz Díaz del CoRral, pues habiendo fallecido aquél hacia el año 1562, los terminó éste el 1564 .

Tampoco debe extrañar ilustrase con láminas un libro de Arquitectura de Sebastián Serlio, porque teniendo facilidad en dibujar y proyectar, nada más natural que los hiciese para esta obra impresa en Toledo, ni debe solprender tampoco trabajase en varios proyectos de retablos, en virtud de sus conocimientos arquitectónicos.

Sin perjuicio de haberse elegido la traza del Maestro Domingo para ejecutar la reja del coro aprobada en Diciembre de 1541, hizo, sin embargro, algunas modificaciones, a juzgar por la aclaración de "que había de tener dos puertas con la misma clase de labor del cuerpo principal de la reja, con su cerradura y dos llaves, revestido todo con el ornato que le corresponde: los resaltos y labrado de las molduras con dos haces de hierro macizo bien ensamblado, y no de chapa, ni como en las molduras algunas hojas y lengiietas a trechos; en los planos, perforaciones a cincel y más enriquecido el friso con arabescos y figuras, Iabrado a dos haces con hierro macizo, a fin de ser mís duradero». 
Habiéndose concertado el Maestro Domingo, vecino de Toledo, con Fernando Bravo, su yerno, para labrar los dos la reja del coro de la Catedral primada, también quisieron hacer lo propio Villalpando y Andino con la del altar mayor, pero como transcurrió el plazo de quince días designado para la aceptación del compromiso, quedó solo Villalpando, sin saber si la causa de no aceptar Andino sería por estar interesado en la empresa de alguna otra obra importante, o porque su amor propio, al no haberse elegido su proyecto para la capilla mayor, le hiciera desistir de asociarse, considerándose por ello rebajado.

Como competidoras, se hallan una frente a la otra las dos soberbias rejas de la Catedral toledana, siendo muy difícil decidir sobre su superioridad, dado el carácter monumental que a ambas distingue, pero en la del altar mayor aumentan el grandioso efecto los dos púlpitos encargados a Villalpando dos años después, porque los anteriores se hallaban apoyados sobre columnas de jaspe y resultaban deficientes al lado de la nueva reja, teniendo la fecha de la escritura cuando se le encomendó la obra en Toledo a 28 de Marzo de 1543 , y en cuya ejecución le ayudó Fermando Biavo.

Este fue otro de los concursantes para la reja de la capilla mayor, coro y púlpitos, pero no habiendo elegido sus proyectos el Cabildo, accedió a trabajar ayudando al Maestro Domingo de Céspedes, por habérselo propuesto éste.

Terminó Céspedes la reja del coro al mismo tiempo que Villalpando la de la capilla mayor, el año 1548, satisfaciéndole el Cabildo 114.870 reales y quince mararedises, incluso los gastos de dorado y plateado: consta de un cuerpo de arquitectura que descansa sobre dos columnas con balaustres cuajados de relieves muy correctos de dibujo y un elegante friso, bien compuestos sus adornos y coronado por esbeltas figuras u ornatos que aumentan su valor artístico.

De suponer es que al trasladar Villalpando la familia y el taller, por encargarse de las varias veces mencionada reja de la capilla mayor, seguiría viviendo después en Toledo, apareciendo haber percibido 400 ducados además del precio de la reja, que era 8.500 , por el importe del traslado desde Valladolid, el aumento del arrastre del hierro y una serie de gastos que le ocasionó todo esto.

Una vez terminada tan suntuosa obra, dedicóse a forrar en bronce las puertas de la fachada de los leones.

Con tan notables obras, compitió, si no superó en primor, Ruy DíAz DEL CoRRAL, cuñado de Villalpando, al ejecutar los hierros para el altar 
de la preciosa Virgen de la Blanca, en el coro de la Catedral toledana, cuyos balaustres son una verdadera filigrana de cincelado del más movido Renacimiento, como todo el resto de tal obra, que parece ejecutada en los más preciosos metales. También fiorecía en Toledo, cual metalario que daba el mayor ange a aquella escuela, Nicolás de Vergara, insigne artista, pintor y escultor, como también proyectista de afamadas obras de orfebrería y metalistería, tales como la urna de plata para el cuerpo de San Eugenio, que hoy se ve en su tesoro, y la traza para la verja en bronce del sepulcro del Cardenal Cisneros, que figura al presente en el crucero de la iglesia Magistral de Alcalá de Henares, a cuyo lugar fue trasladada con el sepulcro desde la capilla de la Universidad, adonde primeramente estuvo.

En 1566 comenzó a ejecutar por sí tan admirable obra, en bronce, no pudiendo concluirla por haber fallecido en 1574 , pero terminóla su hijo, llamado también Nicolás, conforme a la traza y estilo del proyecto de su padre. Quizá fue beneficiosa la intervención de Nicolás y su hermano Juan en esta obra, pues como broncistas habían ejecutado ya los insuperables relieves de los atriles laterales del coro de la Catedral, en las que el arte no puede apurar más sus primores, resultando por ello la verja en cuestión, una de las más acabadas obras de la metalistería hispana.

Su traza general, solemnísima, se ve avalorada por detalles de una importancia artística extraordinaria, pues los jarrones que completan sus esquinas, el blasón de Cisneros que ilustra sus frentes, la labor de sus pilastras y la belleza de los medallones de sus balaustres, son de tan gallarđa composición, que más parecen obra de aquellos broncistas greco-romanos de la antigiiedad que de manos más modernas. Por su belleza extraordinaria figuran sus vaciados como modelos en todas las escuelas, inmortalizando aquella verdadera dinastía de los Vergaras, que tanta altura obtuvieran en la escuela de la metalistería toledana. Aún tendremos ocasión de citar otros ejemplares a ella correspondientes. La verja de Cisneros no quedó terminada hasta el an̂o de 1580 , siendo esto motivo de un pleito, pues los Vergaras se comprometieron a darla por concluícla al año y medio, conviniéndose por fin el Colegio Mayor de San Ildefonso en admitirla y pagar por ella la cantidad de 9.100 ducarlos de oro, más 900 reales, por tres mil libras de bronce en ella empleadas, con los demás gastos.

D. José Amador de los Ríos, en su estudio sobre El sepulcro del Cardenal Cisneros (1), dice, comparando la obra de mármol con la de bronce, que "más afortunada la verja, nada hay en ella que no obedezca a un

(1) Museo español de Antigïedades, tomo V, pág. 358. 
mismo pensamiento y no revele con igual exactitud e integridad una misma ejecución, constituyendo la unidad más perfecta».

A pesar de haber sido postergado Cristóbal Andino, no debió desmerecer su traza, comparada con las otras de tan celebrados maestros, pues como manifiesta Diego de Sagredo en su libro Medidas del Romano, «tuvo el mérito de ser justo en proporciones y elegancia, a juzgar por la reja que en la actualidad construía para la capilla del Condestable en Burgos, que tenía conocidas ventajas a todas las mejores del reino", siendo sensible que en este certamen no fuese afortmado, dada su capacidad artística, ni tampoco en el concurso de la reja de coro para la Catedral de Palencia, sin duda por haber atendido el jurado más a la parte económica que a la calidad de la obra. Por ello, oportuno lugar es éste para que nos ocupemos de la labor de tan insigne maestro.

Xpoval (Cristóbal) Andino, burgalés, educado en el taller de su padre, pronto lo aventajó, dada su afición y profundo amor al estudio; fue escultor, arquitecto, orfebre y uno de los primeros rejeros de España, constando en las cuentas de los documentos del Archivo de la Catedral de Palencia, como "Maestro de trazar rejas y platero».

En efecto, aparece como antor de la reja de la capilla mayor de la mencionada Catedral, segín escritura fechada en Burgos el año 1521, clonde se consigna que los 400 ducados que debe percibir su encargado Juan de Balmaseda, escultor de imágenes, por la reja de enfrente de la sacristía, se entienda es por el primer plazo de la reja de la capilla mayor, ajustada en 1.500 ducadus oro, más 400 por las mejoras, siendo costeada por el deán D. Gregorio de Zapata y el Obispo D. Juan Velasco, cuyos blasones aparecen en ella.

Al ocuparnos de la notable reja que cierra la capilla del Condestable, llamada antes de la Purificación, independiente en la Catedral de Burgos, fundada por D. Pedro Hernández de Velasco y su esposa Doña Mencía de Mendoza, Condesa de Haro, hemos de consignar en primer término el juicio de D. Isidro Rosell al ocuparse de esta joya de herrería en el Museo Español de Antigüedades, diciendo ser una de las más acabadas que en su clase nos dejó el arte de la rejería espan̆ola; su elegancia y gusto exquisito es prototipo del aticismo con respecto al arte del Renacimiento.

Bosarte, al citarla, manifiesta: "entre las muchas y buenas obras de hierro que hemos visto, ninguna merece ser comparada con la reja de la capilla del Condestable», cometiendo un error Ceán Bermúdez al asegurar que la fecha de construcción fue en 1520 , siendo en realidad la de 1523 , según aparece en el tarjetón de la sobrepuerta. 
Lo cierto es que resulta una obra de tan agradables proporciones, fineza de detalles, admirablemente terminados por mano maestra en el repujado, y de aspecto grandioso, que por ella eclipsó Andino a sus antecesores y a gran parte de los rejeros contemporáneos.

Su traza general es tan sencilla como grandiosa: consta de dos cuerpos abalaustrados superpuestos, limitados por frisos, coronándolos un airoso ático; su templete central termina en frontón triangular con la figura del Padre Eterno; bajo éste aparece el escudo del fundador sostenido por dos airosos tenantes, y a los lados preciosos medallones sobre eses contrapuestas; los frisos y balaustres todos prolijamente cincelados, y las hojas de la puerta baten sobre dobles pilastrones interiores, que por sí solos constituyen dos preciosas columnas, cinceladas en toda su superficie; bajo el escudo se lee el nombre del autor: A. B. ANDINO, y en el primer friso la fecha de M-D-XXIII.

El gusto en la policromía y dorado empleado con predilección en esta obra, dando tonos armónicos a las partes arquitectónicas con las figuras y adornos, recuerda la misma mano que la de la reja frente a la sacristía en la Catedral de Palencia, que ejecutó poco más adelante.

Ni una palabra dedica Antonio Ponz a esta preciosa reja, sin duda por olvido o pérdida de sus notas, como también omite citar obras de esta clase existentes en otras muchas ciudades, omisión observada por Ceán Bermúdez acerca de muchas férreas obras capitales.

Según escritura otorgada ante Andrés Sánchez de Palencia, en 28 de Junio de 1530 , se comprometió a labrar la reja lateral del altar mayor de la Catedral de Palencia, frente a la sacristía, enclavada en un arco de desviaje, por el precio de 440 ducados, o más (Ceán dice 400), si mediante tasación pericial lo juzgare conveniente, debiéndosele entregar 60 quintales de buen hierro.

Esta acabada labor policromada y dorada resulta de un efecto admirable por la patina del tiempo: consta de un solo cuerpo con balaustres de adornos alternados en su parte media, revestidos de hojas en la superior, sosteniendo la cornisa cuatro pilastras, sobre la cual se apoya una baja balaustrada que soporta el remate, compuesto por tallos en forma de eses, sobre los que campea el patrón San Antolín en bajorrelieve circular, y a los lados unos floreros más dos medallones, mereciendo elogio por el efecto óptico que supo obtener Andino para evitar resultase baja la reja, aparentando esbeltez, debido al zócalo repujado de la puerta que armoniza con la balaustrada superior.

Por mandato del poderoso Almirante de Castilla D. Fadrique Enri- 
quez, ejecutó además la reja para la capilla del Monasterio de San Francisco en Ríoseco, el año 1532 , cuya obra «excede a los siete milagros del mundo», según decía el Bachiller Villalón, en virtud de la facilidad en labrar el hierro: trasladada más tarde a la iglesia de Santa María de Ríoseco, se lialla hoy colocada delante del coro, llevando la fecha y nombre del autor en la cartela sobre la puerta: A. D. M-D-xxxII= $=$. B. ANDINo.

También parece hizo un sepulcro de metal destinado para la capilla de los Enríquez, que ya no existe.

Un detalle para terminar: Andino fue sepultado en rico sarcófago, admirablemente ejecutado, en la iglesia parroquial de San Cosme, en Burgos, en unión de su esposa Catalina de Frías, al lado de varias dignidades eclesicisticas y otros personajes de noble linaje de su tiempo.

En el an̂o 1520 el MaEstro Hilario labró la suntuosa balaustrada de hierro de la escalera de la puerta alta de la Catedral de Burgos, ricamente exornada con animales fantásticos, metamorfoseadas figuras, medallones, roleos y otros adornos que la comunican artístico aspecto, y que tan bien completa la felicísima creación arquitectónica de Diego de Siloe.

Se creyó obra de Cristóbal Andino en un principio, pero apoyándose en documentos fidedignos del Archivo, se comprobó ser su autor el Maestro Hilario, habiendo sido costeado el antepecho por el Ilmo. Sr. D. Juan Rodríguez de Fonseca, Obispo de Burgos, y desde cuyo lugar se presenta al turista un conjunto encantador al contemplar el majestuoso crucero, las rejas de la nave mayor, el precioso rosetón de cristales de colores y toda la perspectiva que se ofrece a su vista.

En Enero de 1523 aparecen nombrados tasadores de las barandillas Miguer Espinosa y Francisco Vivar, habiendo ejecutado obras en el mismo templo por esta fecha el rejero Agustín Castillo.

Otros ReJeros esPañoles deL siglo XVI.-Aun incurriendo en alguna repetición, debemos fijarnos en otros artistas que completan la lista de los más eminentes en la labor especial de nuestro estudio durante la XVI centuria, así como en algunas obras no menos admirables a pesar de ser desconocidos sus autores.

Debemos comenzar por el célebre compostelano Makstro Guilcés, autor de las rejas del Mospital Real de Santiago de Galicia, ejecutadas según el más probable cálculo hacia el año de 1512, sobre todo la de la capilla, que exornó con el blasón de los Reyes Católicos, más el yugo y el haz de flechas, ofreciendo toda ella un marcado aspecto ojival, aunque 
con tendencias platerescas en algunos detalles, que se acentúan más en la del pórtico, cuya crestería ofrece un movimiento de líneas marcadamente del Renacimiento.

A estos años corresponde la ejecución de la preciosa reja de la capilla bautismal en la Catedral de Toledo, obra del Maestro Domingo de Céspedes, que la terminó en 1524, cuando aún no se había entregado por completo a los modelos del Renacimiento italiano, ostentando entre artístico follaje los escudos del Obispo Fonseca y del canónigo obrero Ayala, que lo era cuando se colocó la reja.

Por la originalidad de su composición, por la riqueza de sus detalles, por el trabajo verdaderamente extraordinario de su remate o copete, corrección de sus figuras y hasta espléndida policromía, constituye un ejemplar de reja española de tan saliente carácter, un tanto oriental, que se separa y destaca de todas las de su tiempo, aunque obedezca a los rasgos del estilo entonces en auge, pero conservando aún todo el carácter más genuíno de nuestro temperamento artístico. Dificultades fotográficas insuperables nos privan de dar trasunto de ella.

También corresponde al Maestro Domingo de Céspedes la airosa verja y rejas de la Capilla de los Reyes Nuevos de la Basílica toledana. Bien se comprende así los méritos que le asistían para que el Cardenal Tavera le adjudicara la ejecución de la suntuosa reja del coro. Murió en 1565, según apunte de Pérez Sedano.

La reja grande de la capilla de los Albomoces en la Catedral de Cuen$c a$, encargada en 1531 por el tesorero de esta iglesia, Gómez Carrillo de Albornoz, ofrece asimismo uno de los más puros ejemplares del arte nacional, siendo muy notable también en este sentido la de la suntuosa capilla del Arcediano de Alba, D. Francisco Sánchez de Palencia, en la Catedral de Salamanca, hecha en el an̂o de 1525, según detalladamente en largo epígrafe de ella se especifica. No son menos suntuosas, a más de las citadas, otras de la Catedral del Burgo de Osma, verdadero museo del arte de la rejería, con la de la capilla de la Virgen de las Cuevas en el claustro de la Catedral de Avila, atribuida por algunos á Juan Francés.

Figura en este tiempo el rejero Maestro García, pero podemos preguntar: ¿MIGUeL, JUAN ó MaRTín?; pues estos tres nombres aparecen como de artistas, a mediados del siglo XVI, en la Catedral de Sigüienza. Consta que Martín García hizo unas rejas para la capilla de Santa Librada, en esta iglesia, y bien pudo ser del mismo autor otra que se construyó en el primer tercio del siglo, toda vez que en 1520 ejecutó las tres rejas del claustro $\mathrm{y}$ "nueve-libras de claros perfectamente hechos, partidos al 
cabo de arriba, al precio de 12 maravedises la libra", segín aparece en las cuentas de este año; pero ignoramos cuál de los otros dos rejeros de igual apellido, labraron las de la capilla antigua de la Concepción y la de Santiago el Zebedeo en el claustro, cuyo importe satisfizo el señor Mora, chantre de la Catedral, como también si fue Miguel quien hizo la reja de la capilla de San Pedro mártir, terminada siete an̂os después, y por la cual le abonaron $14.6 \pm 9$ maravedises; pues el seguntino Juan sólo consta trabajó en el mencionado edificio, sin especificar la labor que ejecutara (1).

Opina el Sr. Pérez Villamil (2), y nos asociamos a su parecer, que las rejas de las capillas de Santa Catalina y San Pedro fueron labradas por el Maestro Juan Francés en 1526 y 1532, aun cuando no consta en las cuentas el apellido, anadiendo por nuestra parte que el epíteto de Maestro Juan no lo hemos visto consignado en otro rejero más que en Francés; por lo tanto, a éste debe de referirse, y más teniendo en cuenta el haber vivido cierto tiempo en Sigiienza.

El importe de estas rejas de la mencionada Catedral verificóse a expensas de los Arces, quienes satisficieron 46.885 maravedises por la de Santa Catalina, y la fundación de D. Fernando Luján la cantidad de 69.565 maravedises por la de San Pedro, sin incluir la pintura, estando plateadas a fuego y embellecidas con adornos repujados de la época, ampliando el coste de la segunda en 6.387 maravedises por su pintura y dorado, que corrió a cargo de los artistas Pedro Villanueva y Francisco de Pelegrina, más 9.866 por los 1.069 panies de oro que se emplearon en ellas.

En el año $155 \pm$ ejecutaba el rejero castellano Francisco Martínez la magnífica reja de la capilla de los Benaventes en la iglesia de Santa Maria de Medina de Ríoseco (Valladolid), obra de puro estilo plateresco, con adornos admirablemente combinados, pudiéndose disfrutar ante ella de su gran suntuosidad y elegancia, tanto por los cuatro esbeltos balaustrones que la dividen, como en la feliz composición del friso y caprichos de fina labor repujada, preciosos medallones y hasta en los remates de ondulantes grifos con que termina la obra, que en su totalidad resulta de un gusto y ejecución excelentes; por ella demostró su autor, relativamente desconocido, comparado con otros maestros de su época, las excepcionales dotes que le asistían. En un tarjetón central se lee el nombre del artista y la fecha en que la terminó: Fran. MARTíNez. = MdLIV.

Ante D. Francisco de Heredia, escribano de número, se comprometió

(1) Véase, para la rejería de la Catedral de Sigüenza, al Sr. Pérez Villamil, La Catedral de Sigïenza. págs. 152, 472 y utras que señalaremos.

(2) En su Catedral de Sigüienza, págs. 255 y 341. 
también Martínez, en 8 de Julio de 1556, en Valladolid, donde residía, a hacer las dos rejas del convento de franciscanos en Ciudad Rodrigo para la capilla mandada construir por el Obispo de Zamora, D. Antonio del Aguila, y en cuyo documento se expresaron las condiciones de la obra, habiéndose estipulado detalladamente en el contrato las dimensiones de las dos rejas, "q" tendrían 11 pies y medio de ancho por 14 de alto, debiendo tener" los pilares sobre el zócalo de piedra siete pies de altos, y el friso con sus molduras otro pie, con las ar'mas de su señoría a dos haces amn' no están en la traça dibuxado: q' haya entre pilar y pilar de espacio igual distancia q' la existente en la rexa de San Benito de Valladolid, de modo q'impida entrar la cabeza de una persona, y los pilares y balaustres sean un poco más gruesos, conforme un dibujo dado por Martinez (su autor), estañándose en lo liso a fuego; todo lo q'estubiese labrado será dorado con oro mate sobre sisa y colorido en las partes q' convenga, siendo los fondos de los frisos azules con los relieves dorados y en color... siendo el coste de las dos rexas mill ducados, y fiadores Juan de Juni, imaginero, y Alonso Huerta, 8 de Julio 1556. Franciseo Martinez". Datos que apuntamos de la obra del Sr. Martí y Monsó.

También son cle su mano otras rejas de menor importancia, y en varias ocasiones salió fiador del célebre escultor Juan de Juni, entre ellas al construir éste el retablo de Santa María la Antigua de Valladolid, viéndose frecuentemente unidos ambos artistas, según cousta en documentos de contratas de obras que ejecutaron.

El Sr. Martí y Monsó exclama, al tratar de este insigne rejero: «¿Por qué Martínez no ha de ocupar un lugar semejante al de Andino o al de Villalpando? Pues tan sólo porque en el azar de las investigaciones artísticas no le ha cabido la suerte de que su nombre sea conocido sino muy recientemente. La reja que lleva el nombre de Martínez (la de Ríoseco) puede competir con las más celebradas en su género y por la grandiosidad de su conjunto, así como por lo bello de las partes y la finura de ejecución, es merecedora de considerarla en primera línea» (1).

Martínez falleció en 1564, dejando ma hija casada con otro rejero llamado Antonio Molina.

Sobrevinole la muerte en tal año cuando ejecutaba el encargo de las rejas para el convento de la Santisima Trinidad Calzada, en Valladolid, fundado por el doctor D. Bernardino Sala, que liubo de terminarla GASPAR Rodriguez, vecino de Palencia, o de Segovia según otros.

(1) Estudios kistórico-artisticos, pág. 488. 
También fue designado Gaspar Rodríguez para terminar la reja de la capilla de Fabio Neli, en Valladolid, donde descansan los restos de D. Suero de Qniñones, y la verja de su sepulcro, según convenio fechado el 21 de Mayo de 1522, entre él y María de la Pen̂a, viuda del rejero Alvaro DE LA PEÑA, que las había dejaclo sin concluir.

El año 1555 concursaron para la construcción de la reja del coro de la Catedral de Palencia, JuAn LóPEz, vecino de Toledo, ofreciendo hacerla dorada por 4.300 ducados y sin dorar en 4.000; Benigno Moreno, de Palencia, en la cantidad de 5.000 ducados; JUAN DE OLISARRI, residente en Mondragón; Alonso Barco, de Valladolid, hizo postura a la reja por seis mil (?) ducados; Maestre Pedro, de Palencia, en 5.000 ducados; Gaspar Rodrígnez, de Segovia, propuso construirla en 3.400; JuAx Corral de VILlatpaxdo, de Palencia, mediante poder presentado por Francisco Villalpando, en 5.000 ducados, el cual hizo algunos trabajos de herrería en esta ciudad; Llorente Herreros, vecino de Valladolid, en 7.000, pero con la. condición de ser los nihos de la Coronación y demás figuras de bronce; habiendo sido rematada la obra en pública subasta a favor de Gaspar Rodríguez.

Según se observa, la ejecnción de obras artísticas se adjudicaba por subasta generalmente, cual si se pudiera ejecutar de tan anómala manera una labor de esta índole, bastando sólo hacerla mís barata que otro solicitante, para saber quién había de ser favorecido, teniéndose presente la economía sin examinar la, calidad del trabajo.

Lo cierto es que, mediante el precio de 3.400 dncados, le fue adjudicada a Gaspar Rodrígnez la reja del coro, cuyo importe satisfizo la testamentaría del Ilmo. Sr. D. Luis Cabeza de Taca, según aparece de la escritura otorgada ante Tomás Paz, previo convenio con el Ilmo. Sr. Don Pedro Gasca, Obispo de Palencia, el día 2 de Noviembre de 1555, terminándose la reja en 1571, a juzgar por el rótulo escrito en su zócalo de piedra, sobre el cual descansa.

Distínguese esta reja por la corrección de su traza y grandiosidad de sus adornos, del más suntuoso Renacimiento, ostentando en su ático y crestería los blasones propios de sus fundadores.

Toledo y Serilla fueron en esta floreciente época las dos ciudades más importantes donde se reunieron los maestros rejeros aventajados, y el lugar donde ejecutaron obras admiradas por todos; también, annque en menor escala, descuellan Burgos, Granada, Sigiienza y otras ciudades, hasta el extremo esta última de llegar a formar escnela en el arte de trabajar el hierro; pero además de cerrajeros eran relojeros en gran maỵo- 
ría; tal aconteció a MaRtín García, que en 1520 y 1525 tenía a su cargo el arreglo del reloj de la Catedral; Jerónimo de LA Fuente, como constructor del reloj para el coro en el año 1547, y Pedro Pastrana, que floreció en el siglo XVIII, demostrando sus aptitudes varias familias de rejeros, que después resultaron aventajados relojeros, repartidos por diversas provincias.

Vecino de Cuenca Hernando de Arenas, le encargaron la reja del coro de aquella Catedral el año de 1557, y tal vez los atriles, aun cuando sólo consta haber hecho unas águilas de hierro para la misma iglesia; fue discípulo predilecto de Sancho Mnnooz y continuador de la escuela de éste, y de Cristóbal de Andino, habiendo también encargado a Arenas el Cabildo de la Catedral de Sigiienza la reja de la capilla de las Reliquias, por ser maestro conocido en Castilla en obras de rejería hechas en Sevilla, Jaén y Cuenca.

Ofrece la de las Reliquias un correcto y bello conjunto, motivado por su elegante composición y aspecto monumental, con las figuras y adornos terminados escrupulosamente en su repujado, cincelado y policromado, si bien reconocemos carece por sus menores dimensiones de la suntuosidad de la ejecutada para Cuenca, mas extensa y grandiosa en su total efecto.

Curiosa es la investigación verificada por el Sr. Pérez Villamil al decir que no fue el dibujo de la reja de las Reliquias original de Hernando de Arenas (y seguramente también de las principales hechas, añadiremos), sino un tal JAIME, entallador, a juzgar por la cuenta de data, según manifiesta el canónigo obrero al ocuparse de este trabajo, diciendo: se le reciben cuatro ducados q' pagó el dcho Fcrnando Aiencis, rexero, por su obra cuando vino al concierto de la Rexa y traer la traça, lo cual nada tendría de particular si a renglón seguido no apareciese: item tres ducados q' pagó a Jaime, entallador, por la traza de rexa q' hizo (1).

Como daba la coincidencia de vivir éste en Cuenca, donde trabajaba un famoso escultor conocido en Toledo por sus obras, a quien Ponz llama Xamete, Jaime (en catalán y valenciano Jaume), que hacía dibujos por encargo para altares y monumentos, no debe extrañar comisionase a este Arenas, con objeto de hacer composiciones de las rejas, si carecía de las condiciones de originalidad, aun cuando su práctica como maestro rejero fuese muy grande.

Hizo además la reja de coro de la Catedral de Jaén.

Digno de mención por esta fecha es el rejero Pedro Sabaté, que en

(1) Catedral de Sigïenza, pág. 321. 
el año 1550 recibió a cuenta de "la obra" de la Catedral de Barcelona la cantidad de 41 libras y dos sueldos, importe de las rejas de las capillas de San Pedro y San Nicolás, ésta conocida por la de Nuestra Señora del Patrocinio (1).

En la región aragonesa, mno de los hábiles rejeros más celebrados fue Guillén Trujallón, que trabajó en las dos rejas de bronce para las capillas de San Bernardo y San Benito de la Seo de Zaragoza, habiéndole sido abonada la cantidad de 1.800 escudos el día 2 de Marzo de 1556, según orden del Arzobispo D. Hernando de Aragón, dato tomado de la «Historia Cesarangustana Eclesiástica» del Maestro Diego de Espés, del archivo de la mencionada iglesia; trabajó también en varias obras con destino á la parroquia del Salvador de la misma cindad, suponiendo además a un hijo o discípulo de Trujallón antor de las tres rejas de bronce colocadas a la entrada y debajo del coro de la iglesia del Monasterio de EI Escorial.

Sobre este particular hemos de consignar que hubo otro rejero llamado Guilléx de Luxarón, renombrado artífice aragonés, residente en Zaragoza, que hizo tres rejas para el Monasterio de El Escorial, según escritura otorgada con Pompeyo Leoni el 15 de Octubre de 1579.

¿Será éste el apellidado Guillén Trujallón, o el Maestro Guillén?

Dedúcese fueron personas distintas, fundándonos on que la obra de las tres rejas no se tienen como cierto las construyese Trujallón, aun cuando, por otra parte, hay la circunstancia de haber trabajado en bronce en las rejas de La Seo, de Zaragoza, y en igual materia en las de El Escorial, con la coincidencia de tener gran fama los dos en Aragón, lo cual contribuye a suponer si sería un mismo rejero.

En 1563, el maestro cerrajero Francisco NúÑez hizo la reja para la capilla mayor en la iglesia de Santiago, en Cáceres, calificada de "excelente»; es dorada y pintada, de estilo del Renacimiento, ostentando medallones, roleos y adornos de exquisito gusto, destacándose en el centro un Crucifijo como remate.

Entre los varios rejeros que acudieron al remate de los antepechos de las ventanas ejecutados en hierro para el entresuelo del Alcazar de Scvilla, fue uno Francisco Gallego, quien en unión de González Barbosa, que en Mayo de $15+3$ hizo unas quicialeras y abrazaderas para las ventanas de las Casas Capitulares, convinieron hacer la obra citada en 9 de Junio de 1546, cuya fecha coincide con haber trabajado el rejero Jerónimo de la Fuente en la Catedral de Sigiienza.

(1) Libro de Obra del año 1549 al 5l, pág. 139. 
En 23 de Octubre de 1549 fueron rematantes, quedáudose con la obra de once antepechos de hierro para el quitasol alto del Alcazar de Sevilla, Sebastiáx Gonzàlez y Estéban Pérez.

De Juan Barba sábese trabajó en unión de Francisco López en la reja de la capilla de la Antigua en Sevilla, el an̂o 1572; a la vez en otras obras para el mencionado Alcázar, y un balcón para las casas del Cabildo, próximo a la Contaduría; así como JuAx Corbella ayudó en la construcción de los atriles y otros trabajos para la Catedral de Toledo a los Vergaras, padre e hijo, el an̂o 1570; finalmente, Pedro Rebollo hizo diversas rejas y cerraduras para la Cárcel sevillana en 1570 .

Varios rejeros florecieron hacia el año $1578 \mathrm{con}$ el nombre de Juar Bautista, apellidados uno de Valencia y otro Palencia, este último hijo del herrero Antón de PALExcia, que trabajó en varias obras de Sevilla el año 1554; de Juan Bautista de Valencia son las rejas de ventancıs para la Sala de Fiestas del Alcizar.

Cítase además por haber trabajado también en el Alcázar en 1579 a Pedro Nieva, así como a Juan Fernindez, autor de seis rejas antepechos para otras tantas ventanas, en el corredor que cae sobre el estanque grande del jardín del Alcázar sevillano.

Completando los rejeros que florecieron en Sevilla durante la décimosexta centuria, diremos que entre las escasas obras de LUIS DE SAN MARTís, hay que mencionar varias rejas para ventanas, que se colocaron en Sevilla el año 1554, aun cuando se ignora el edificio, como asimismo la reja de la Cárcel y unas cerraduras grandes para la Puerta de Hierro, en la propia ciudad.

Un Juan Bautista aparece haber hecho las dos rejas del Cucto del Sol en el Alcázar de Sevilla el año 1578 (y otra el rejero JuAx Piseda para el mismo local en 1592), del propio modo que una reja vulgar, pero bien forjada, construída con destino a la cámara de la Sala de los Majaderos, y las de las ventanas de la Sala de las Bóvedas y Baja del Marmol, del citado edificio (1).

Ahora bien; ¿este Juan Bautista puede referirse al que tiene el apellido Celma? Indudablemente no.

Varias dudas y confusiones ocurrian respecto a tres artistas de apellido Celma, pero de ellos diremos que, en nuestro concepto, el Sr. Martí y Monsó resuelve el asunto al leer en sus interesantes investigaciones que

(1) Véase, para más detalles de rejeros en Sevilla, el Ensayo de un Diccionario de artifices que florecieron en esta, por D. José Gestoso y Pérez, en su sección de «Rejeros», y en lo correspondiente de su Sevilla monumental. 
Benito Celma fué escultor, Juan Bautista Celma rejero y pintor aragonés y Juan Tomás Celma, figura unas veces como pintor y otras de rejero y escultor, según lo atestigua la reja del coro para la iglesia de San Benito el Real de Valladolid, leyéndose en ella «Joan Tomás Celma me fecit 1571 ,

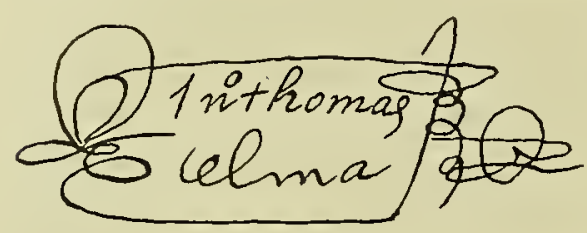
resultando, por lo tanto, ser tres firmas distintas de diversas personas.

Bosarte, al tratar de las rejas de Valladolid, decía: "Uno de los maestros de hacer rejas... fué Juan Tomás Celma. De su mano es la reja del coro de San Benito el Real... riquísima de adornos de buen gusto. Hay en esta reja dos cartelas: una mira al interior del coro, y la otra al altar mayor; en una se lee: JVAN TOMAS CELMA ME FECIT, y en otra: $1571 » \ldots$

"Si este Juan Tomás sea distinto de Juan Bautista Celma, que se firmaba como pintor en otras obras de hierro en iglesias, no lo sé...» Igual pregunta hace el Conde de la Viñaza en sus Adiciones. El punto queda suficientemente aclarado, como decimos, gracias a la diligencia del seňor Martí y Monsó.

Indudablemente constituyeron una familia de artistas de origen aragonés, cultivando con especialidad cada cual su arte, aunque como otros de la época no se contentaron con ejercer uno solo; pero las firmas de Benito, Juan Bautista y Juan Tomás son perfectamente distintas, y por documentos conocemos también a sus propias mujeres, Catalina Ruiz de Durama y Magdalena de Cembranos, de los dos últimos, respectivamente (1).

Juan Tomás tenía treinta y siete años en el de 1555, según manifestó en un curioso pleito que pusieron los frailes del Monasterio de San Benito a Berruguete, sobre si podía o no vender el vino de su bodega, habiendo entonces nacido en 1518; como pintor interpuso una demanda al boticario D. Bello, pidiendo "se aga compensación... (por medicinas) con ciertas obras de pintura que le hizo, y no se las pagó».

De Juan Tomás son las rejas de bronce del coro de la iglesia del Pilar de Zaragoza, pobladas de esculturas y delicados adornos, empezadas en el año 1574 y terminadas dos an̂os después; en cuanto a Juan Bautista Celma, fue el que hizo la del coro de la Catedral de Burgos, en sustitución de la que había de madera, según escritura por la cual se obligó a construirla.

Mediante escritura ratificada en Valladolid el 21 de Marzo de 1600, se comprometió Juan Bautista Celma, vecino de Santiago de Galicia y pin-

(1) Véase Martí y Monsó, Fstudios histórico-artisticos, pág. 555. 
tor, por si mismo y en nombre de catalina rruiz de durama mi mujer y de rafael Zelma mi hixo vecino de Plasencia... tomo hacer una rexa de yerro en el coro de dicha iglesia (Catedral de Burgos), en lugar de la q' agora está de madera... la dcha rrexa la acauari y la pondra en perfeccion dentro de año y medio.

Se cree fue costeada, en 1602 , por la fábrica de la iglesia, pero supone Cantón que el Cardenal Zapata dió 5.500 ducados para esa

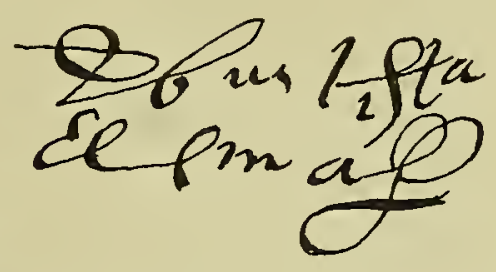
reja, cuyo diseño era del pintor Gregorio Martínez, previa aprobación de Juan de Arfe, con ciertas morlificaciones antes de ejecutarla.

Debajo del crucero cierran los arcos de la nave mayor dos magníficas rejas de bronce regaladas por el Obispo D. Manuel de Navarrete Ladrón de Guevara, así como los púlpitos, más seis rejas que ocupan igual número de arcos, que satisfizo el Arzobispo Peralta, mandadas dorar despucis por el Cabildo, a expensas de la fábrica y del Arzobispo Isla.

Obra suya también son los dos puilpitos de bronce para la Catedral de Santiago, según se lee en ellos: "Joanes Baptista Celma Aragonensis 1563 Compostelle faciebat", formando cada lado del púlpito un cuerpo arquitectónico con cornisa y resaltos de orden corintio, teniendo en los intercolumnios bustos y seis bajorrelieves en el zócalo con episodios de la vida del Apóstol Santiago, y apoyándose las basas sobre tres sirenas de entrelazados brazos; y por último, construyó la reja de coro de la Catedral de Plasencia, digna de ser alabada, representando en el coronamiento la Asunción de la Virgen, y a los lados David y Salomón, y leyéndose en el pedestal esta inscripción: "Jrannes Baptista Celma pictor faciebat - anno Domini 1604».

No hay que extranar, pues, que Juan Bautista Celma firmase sus contratos de rejería llamándose pintor, porque en efecto también lo era, como se ve en el que hizo para el retablo de la capilla de dońa Francisca Mudarra, en el monasterio de San Benito, de Valladolid, en unión del entallador Francisco Velasco (1).

El herrero Alvaro de la Peña, vecino de Valladolid, comprometióse a hacer la reja para la capilla mayor de la iglesia de Sancti Spiritus, propiedad de Juan Ortega, mediante escritura otorgada ante el escribano Antonio Rodríguez a 8 de Diciembre de 15\&2, siendo fiador el imaginero Esteban Jordán: ...q' la han de hacer por la forma, orden y traça a modelo q' se contiene en vn patron... de muy buen fierro é nuevo sin mezcla

(1) Véase Martí y Monsó, Estudios histórico-artisticos, pág. 554. 
de ningun viejo... ha de pesar diez myll libras é no mas por el precio de myll ducados.-Dixo alvaro de la peña $q$ ' no sabia escribir.-

De extrañar es no aplicasen el hierro viejo en la obra, por su ductilidad y buen éxito de la parte técnica.

Con motivo de su fallecimiento dejó sin terminar la reja para la capilla de Don Suero de Quiñones, y la del sepulcro (antes denominaban entierros) del fundador, para lo cual venía obligado a ejecutar las dos obras, según compromiso de 8 de Octubre de 1585, mas como no lo pudo verificar, se otorgó un documento fechado en 21 de Mayo del año 1592, mediante el cual su hija María de la Peña, en unión del rejero Gaspar Rodríguez, habían de terminarla.

La Obra de la Catedral de Barcelona pagó al maestro Pedro Senit, cerrajero en 1581 , la cantidad de 33 libras, un sueldo y seis dineros, por unos candelabros para la capilla de Santa Eulalia (Libro de obra de 1581 a 83, pág. 55), y en 18 de Noviembre de 1583 Sebastián Navarro se presentó como postor en la subasta de las rejas de la Sala de Fiestas en el Alcaizar de Sevilla.

Consta, por último, que Francisco RuIz percibió la cantidad de 13.756 maravedises el día 3 de Diciembre del an̂o 1586, por la reja, con su claraboya, de una ventana del cuarto de Hércules, en el corredor del cuarto real del Alcazar, y en la misma época, Diego Corbella hizo otras para el mismo edificio, trabajando también JuAN SALAS, por lo que se le abonaron 11.t18 maravedises de una reja con antepecho para ma ventana del Alcázar, a razón de 33 maravedises por libra.

Otros objetos de hierro ex el siglo XVI.-Rejas de ventanas. A más de las grandes rejas para las capillas de nuestros templos, de las que hemos hecho la mención debida, consagráronse los mismos maestros a otras obras menos importantes, pero no por eso de menor mérito y valor artístico. Entre éstas ningunas más lindas ni de mayor efecto que aquellas rejas exteriores para los más suntuosos edificios, con que pretendían defender, a la par que embellecer, los huecos de sus fachadas.

Después de haber consignado algunas tan originales como las de la Casa de las Conchas, en Salamanca, la de la Casa de Pilatos, en Sevilla, y otras, no podemos menos que estimar este género de obras como una nota especial de nuestra rejería, en la que tan bellos ejemplares contamos. Acredítenlo sino las de muchas fachadas de Avila, entre ellas la llamada de Mosén Rubí, de tan valiente repujado; la de las monjas de la Concepción y otras, así como las preciosas del Hospital de Afnera, de Toledo, con tan 
hermosos remates; las del Infantado, de Guadalajara; algunas en Trujillo, suntuosas, y otras en apartados pueblos, que nos sorprenden por la riqueza y gallardía de sus perfiles. Algunas veces adquirían proporciones tan extraordinarias como la del convento. de la Magdalena, de Toledo, imprimiendo a las calles un aspecto tan pintoresco como la que reproducimos.

También se construyeron en este siglo suntuosas cancelas de cerramiento o de puertas de entrada, tan notables como las de la Casa de Pilatos, en Sevilla, consignadas, a las que quizá supere la preciosa más exterior del edificio de Santa Cruz, en Toledo, de autor ignorado, pero que debe estimarse como de alguno de los mejores maestros que en tan artístico centro florecieron, cual puede apreciarse por la lámina.

Más abundantes tales rejas que los balcones entre nosotros, no faltan algunos de éstos, desplegando su mayor arte en los hierros que los sostienen y en las palomillas de sus tejaroces. Así era el que hubo en la ilustre casa de Zaporta, en Zaragoza, conocida vulgarmente por de la Infanta, sin duda por haber servido de residencia a la esposa del Infante D. Luis, $\mathrm{y}$ donde murió el insigne Pignatelli el an̂o de 1793; a mediados del siglo XVI, según decimos, debió colocarse el suntuoso balcón que tenía sobre la puerta de su fachada, compuesto de un cuerpo central curro que se destacaba de la barandilla paralela al muro. Hoy nos remos privados de admirar esta joya del arte de la rejería, por haber seguido la misma triste suerte que el precioso patio de la casa, enajenado al extranjero.

Dos suntuosas verjas de lierro, de dos sepulcros famosos, se batieron en el siglo XVI dignas de mención especialísima: la del Obispo Anaya, en su capilla de la Catedral de Salamanca, y la que rodea el baldaquino de San Juan de Ortega, en su iglesia, en la provincia de Burgos.

La primera, indudablemente más suntuosa y original que la segunda, es una de las más peregrinas obras de la rejería espańola: en ella no sólo apuró su autor el buen g’usto en los detalles, sino que los técnicos ren allí aplicados todos los procedimientos que pueden usarse para la más adelantada labor del hierro, pues como dice el Sr. Rico y Sinovas (1) «el artífice que concluyó la preciosa obra férrea, para calar y repujar en hierro, de primera intención hizo uso de los dibujos en papel calado a tijera ", observándose además en ella la aplicación de los retorcidos a fragna, repujado, cincelado, limado, pulido, ensamblado, emperlado y cuantos recursos puede emplear el más diestro herrero para llevar a cabo la labor más complicada. De su autor no tenemos noticia alguna.

(1) Véase Historia y Arte, I, pág. 206, donde insertó el Sr. Rico y Sinoras un detenido estudio sobre esta verja. 
La segunda, más seneilla, pero no por eso menos bien trazada y artística, acusa por sus proporciones, frisos y gallarda erestería, los más puros caracteres del arte del Renacimiento en la fecha que se ejecutó, pnes, según sus cartelas, Diego de Vargas, secretario del Rey-la mandó hacer año 1561. Ningún otro dato poseemos sobre el autor de esta excelente obra.

También los útiles para el eulto ofrecieron muestras brillantes de la labor del hierro en este siglo, aplicándose a candelabros tenebrarios tan notables como los de Jaén, Burgos y de San Pedro de Avila, grandes blandones para el cirio pascual, como el de Jaén y otras Catedrales, transformándose en mno de éstos los tenebrarios de Avila y Burgos, una vez pasada la Semana Santa.

Con igual destino de sostener gruesos cirios hicieron otros hermosos blandones para delante de los altares, ofreciéndose como sobresalientes ejemplares los que se guardan en el Museo Arqueológico Nacional, procedentes de la Catedral de León, y de los que por su especial importancia damos lámina correspondiente.

Variadísimos son los ejemplares y earácter de los candelabros al final del siglo XVI, acentuánclose la superposición de varias piezas, pero naciendo siempre la superior de la inferior, sin que puedan sustituirse las piezas de que se hallan formados ni suprimirse ning ma sin perjuicio de la totalidad. Regularmente constan éstos de cuatro partes: basa (plinto sobre el que se sostiene); jamón (cuerpo decorado con cabezas u hojas); balanstre (fuste liso o estriado), y arandela (platillo con borde exomado).

Estos utensilios, prodigados para ceremonias religiosas y usos domésticos, eran de reducidas o yiganteseas dimensiones; algunos con corona de luz giratoria, provistos de trípode, aeusando la forma de planta provista de tallos que soportan las antorchas en una especie de tubo o dedal, cuya hechura conservó hasta fines del siglo XVI.

Figuran entre los aparatos de alumbrado la limpara ordinaria suspendida, las portátiles, como las linternas destinadas para acompañar al Viático, alumbrar los difuntos al conducirles al cementerio, nsándose además en las procesiones y otras ceremonias.

En las coronas ardientes, candeleros y candelabros se aplicaron los cirios, como era costumbre, pero hemos de señalar que son varias las comarcas en las que los candeleros y demás objetos tienen un sello especial que les distingue de los de otras, como por ejemplo, en los citados del Museo Arqueológico Nacional, donados por el Cabildo de la Catedral de León, que son de estilo plateresco muy característico en Castilla, a diferencia del 
arte catalán, que aun cuando carezcan de la típica flor de lirio, varían, sin embargo, de los de otras comarcas, conservando siempre algo del carácter de los modelos medioevales.

Cerraduras.-Construyéronse muy notables en este siglo, pues llegó a tanto su labor que sorprende pudieran ejecutarse con tan ingrato metal, cubriéndolas de filigrana y correctos dibujos, introduciendo hasta figuras en relieve, a la vez que los más ingeniosos mecanismos en las llaves; recordamos a propósito de esto las dos puertas, una de hierro con balaustres y otra de chapa claveteada, del notable archivo de la Catedral de Burgos, que se hallan casi unidas paralelamente y tienen la particularidad de abrirse primero la de más adentro, precisando saber el secreto, pues de lo contrario no se prede entrar; esto demuestra el conocimiento ingenioso del arte de la cerrajería, en el que los maestros burgaleses fueron célebres, corroborándolo en los resortes de la cerradura de la puerta del salón de la Casa-colegio Notarial, que al abrir suenan doce campanadas e igual número al cerrar, revelando en sus secretos no vnlgares conocimientos. Pero aunque en sus detalles siguieron las cerraduras exomadas al gusto de la época, bien puede decirse que conservaron siempre su traza primitiva, recordando su carácter medioeral hasta en los muebles del siglo XVIII. Por ello presentamos como modelo notable la de la puerta principal de la iglesia de Santo Tomás de Avila, pues amque puerle estimarse como de gusto gótico, fué sin duda ejecutada muy a las proximidades del comienzo de la XVI centuria.

Clavos. - Ya manifestamos que los mejores rejeros castellanos superaron a los extranjeros, y en lo referente a estos adornos que cubren algunas puertas de iglesias, castillos o casas de linajuda estirpe, hicieron felices combinaciones, siu olvidar la ordenada disposición ornamental, avalorando la obra de carpintería sobre la que los aplicaron.

Como los clavos más lujosos del siglo XVI deben ciertamente estimarse los de las puertas de la iglesia de Santo Tomás de Avila, en alguuo de los cuales han llegado a contarse hasta diecisiete piezas, y los de las bandas superiores de las de la Universidad de Salamanca, sin durla éstos los más complicados que tenemos.

A modo de palomillas, fueron las griıas giratorias destinadas a colgar objetos; terminaban por regla general en ma cabeza de animal fautístico, demostrando en ellas sus antores mu variadamente su ingenio. según se observa hasta en el siglo XVIII.

Las balanzas constituyen otro trabajo delicado de cerrajería, artísticamente adornadas con labores de la época, conservando el ILuseo epis- 
copal de Vich un ejemplar curioso de fines de este período, admirablemente compuesto con hojas repujadas de acanto.

En cuanto a las cmees, aparecen prodigadas profusamente: este signo de la redención le aplicaron los herreros en diversas obras, desde la cruz procesional de múltiples formas, sin basa, como la conservada en el Museo municipal de Barcelona, de fines del siglo XVI, hasta la provista de ese sostén, que era generalmente de basa triangular, a semejanza de los candelabros, candeleros u otros objetos, sin duda para obtener mayor solidez independiente de la suposición de representar simbólicamente las tres Virtudes Teologales personificadas en los tres Arcíngeles adoptados por la Iglesia latina, siendo como tipo excepcional la basa cuadrangular. Las cruces de término, colocadas en los límites jurisdiccionales, revelan mayor originalidad, sucerliendo lo propio en las cruces veletas.

Muebles de hierro.- - A esta categoría pertenecen los cofres ferrados o arcas de caudales. Hay cofrecillos góticos con doble chapa de hierro exterior, de prolija labor calada. En cuanto a los cofres grandes, unos son de madera con herrajes, consistentes en cerradura, abrazaderas y asas; otros, que son a los que mejor cuadra el nombre apuntado, son de chapas de hierro, reforzadas con bandas entrecruzadas y claveteadas, siendo lo más notable el cierre de seguridad, compuesto de una serie de pestillos dispuestos en forma.radial sobre la cara interior de la tapa, convergentes al centro de la misma, donde está el ojo de la llave. Este ingenioso cuanto complicado mecanismo va cubierto con aplicaciones de chapa calada y grabada; de manera que el lujo artístico de estas arcas del siglo XVI va en la cara interior de la tapa. El Mtuseo Arqueológico Nacional conserva dos excelentes ejemplares regalados por la señora Duquesa de Villahermosa. 


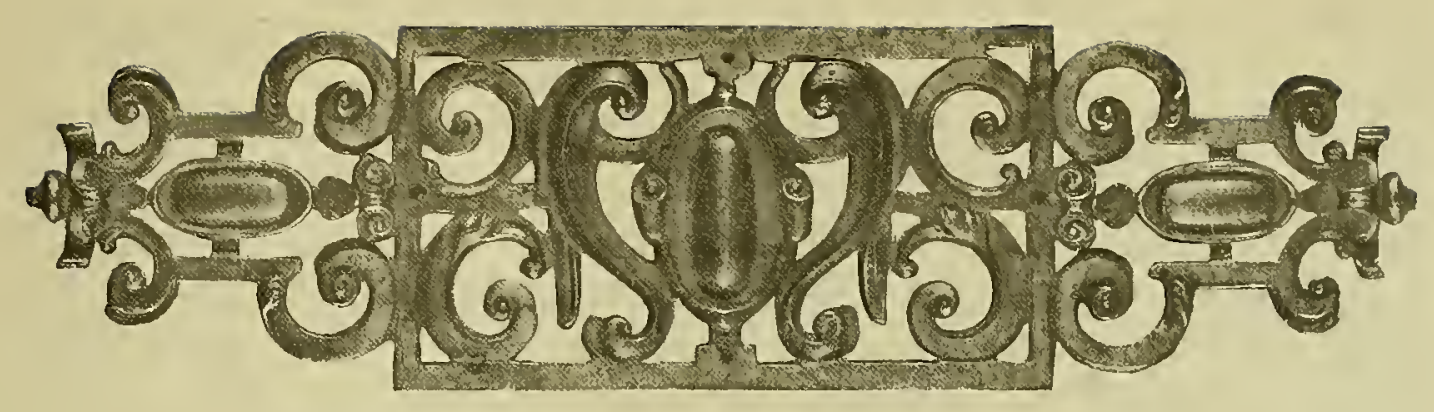

E P O A C U A T A

\section{Siglo XVII.}

Así como la anterior centuria constituyó el período del mayor desarrollo en nuestra industria artística del hierro, admirable por el grado de perfección alcanzado, en cambio en el siglo XVII se inicia una decadencia tan marcada, que comenzando por el procedimiento técnico, invadió también el estilo decorativo y el gusto artístico.

El ocaso del Renacimiento lo motivó el deseo de buscar en las producciones un solo orden grandioso y severo de líneas (el greco-romano), cultivado por Herrera en el edificio de El Escorial, escondido en las desiguales vertientes del Guadarrama.

En la rejería, como en las demás artes, se sintió la influencia de la época, resultando ya de menor importancia las obras, lo que fué acentuándose más en el siguiente siglo, descle el trabajo de forja hasta la falta de interés en la prueba de aptitud de las pasantías de los gremios, pues los ejercicios se limitaron a la simple ejecución del objeto en Iugar de apreciar la originalidad artística.

La Metalistería o, según dice D. Ramón Soriano, la Ferretería es la que representa en este período mayor deficiencia, desgraciadamente, entre las artes industriales, estando pervertido el gusto hasta el extremo de pintar las rejas y balcones de Madrid de color azul, como manifiesta Bosarte, cual si hubiese hierro azul ni cosa de que poder hacer un balcón que sostuviese el peso de las personas que por él se asoman, pues no representando el hierro, según el citado escritor, más que este metal, debe omitirse el colo- 
rido del mismo; pero apesar de que esta manifestación vaya conforme con la propiedad de los tonos variados de cada objeto, refiriéndose a los aplicados por el rejero Cristóbal Andino en su majestuosa reja de la capilla del Condestable, en Burgos, al dar el color de carne a las figuras, los verdes en los follajes, así como en los fondos rojo y azul que contribuyen a destacar adornos, y las combinaciones de oro en cornisas o puntos salientes, hay que convenir en que su mayor efecto sería cuando estuvo recién pintada con vigorosos colores; pues nunca la policromía bien aplicada ha perjudicado al efecto de las obras de arte, sobre todo cuando responde a la inspiración de sus antores.

La severidad de las líneas arquitectónicas quitó el guusto artístico dominante en pasadas centurias, obligando después al herrero a buscar nueros giros para dar mayor gracia a sus trabajos, aunque sin conseguir aquéllos tan gallardos del siglo anterior, y preparándose al final para admitir los del barroquismo, en el que encontraremos ejemplares por cierto muy notables.

Los balaustres de las rejas en este periodo son torneados sencillamente, dorados o de bronce en lugar de los adornos del siglo anterior, estando algunas rejas de hierro chapeadas de plata como la de la capilla de Fuencisla, situada en las afueras de Segovia, y la del Sagrario, en la Catedral de Toledo.

Aquella decadencia no fué, sin embargo, tan rápida e inmediata que no se ejecutaran al comienzo de la XVII centuria algunas rejas notables, conservando aún mucho de la tradición de las anteriores. Entre éstas debemos considerar la del presbiterio de la iglesia de San Pedro Mártir, en Toledo. digna de ser presentada como modelo de grandiosidad y perfección técnica, sobre todo en su gallarda crestería, por lo que damos de ella lámina correspondiente. De autor desconocido, pero manteniendo aún toda la gracia y suntuosidad en su trazado de los más famosos renacientes, bien es digna de la escuela local a que es debida.

El año 1605 el herrero Hernando de Espinosa cobró 2.000 reales importe del resto de una cuenta de la pequeña reja de la capilla de la Antigua, en la Catedral de Sevilla, y sábese que trabajó con Fray Francisco de Salamanca en 1547, según cita éste.

Juan de Arfe menciona al herrero Alejandro de Armolea o ArmaoLEA, en una carta fechada en Madrid a 7 de Diciembre de 1602 dirigida al tesorero del Duque de Lerma, por haber ejecutado cuatro verjas para los sepulcros de esta familia, en la que consigna regresará en breve Armaolea, cerrajero muy conocido por los trabajos hechos en la iglesia de San 
Pablo, de Valladolid. También auxilió a Arfe en la fundición de las estatuas de los Duques de Lerma.

El rejero Matías RuIz hizo la de la capilla en la iglesia de la Magdalena, de Valladolid, donde está sepultado D. Pedro de la Gasca, Obispo de Siguienza, fallecido siendo Virrey, Capitán general del Perú y Obispo de Palencia; fundada la expresada capilla, convino Ruiz en la forma, labor y dibujo de la reja, aun cuando no fue suyo el proyecto, sino de Esteban Jordán, autor del sepulcro labrado en alabastro de Cugolludo, que hoy se admira en el centro de la capilla.

Prueba de no ser hábil dibujante Ruiz lo confirma el que la reja forjada por éste en 1614 con destino a la capilla del Licenciado Juan de la Corte, en el convento de la Trinidad, la proyectó el cantero BarTolomé CALzADA, o mejor el escultor Pedro de la Cuadra, maestros de la obra, de los que existen algunos diseños de rejas con sus firmas, por esta época (1), y atestigua la limitada inventiva de este herrero, al ver el balcón grande de la fachada en la iglesia de las Angustias, de Valladolid, que es de vulgarísima forma, y que fue puesto el 18 de Agosto de 1605.

Entre las obras de construcción y reforma del palacio y convento de San Pablo, de Valladolid, encargadas por el Duque de Lerma el año 1601, figuran ocho balcones, que ejecutaron Matías y García RuIz (¿hermanos?), dando por terminados los balaustres de hierro conforme el modelo a que se comprometieron en 27 de Octubre de 1614, hallándose asociados también en esta obra el cantero Bartolomé Calzada, recino de Valladolid, y el escultor Pedro de la Cuadra.

El an̂o 1607, con motivo de no haber hecho BARToLoné Rodriguez más que la reja de la capilla de Nuestra Señora del Sagrario, en la Catedral de Toledo, por encargo del maestro mayor D. Juan Bautista Monegro, que dirigió la obra, confió este arquitecto y escultor al cerrajero LuIs DE PENAAfel todas las rejas de puertas y rentanas que no ejecutó Rodríguez en aquel año; también, en igual fecha, el rejero Francisco Silva, escultor e ingeniero, trabajó con Luis de Peñafiel en las rejas de puertas y ventanas de la capilla del Sagrario, en la Catedral primada.

Juan Miranda tuvo a su cargo la obra de la rejería del edificio llamado "El Apeadero», en el Alcázar de Sevilla (1608), y el siguiente año hizo un balcón grande de hierro, con su correspondiente balaustrada torneada, para colocarle sobre la Puerta de Canteria del Apeadero, más otros dos balcones en el Apeadero nuevo y diez paños de barandilla, torneados y escru-

(1) Véase Martí y Monsó, Estudios historico-artisticos, pág. 18. 
pulosamente limados, con destino al Cuarto de las Muñecas del citado Alcázar.

El vallisoletano PEDRo DEL BARCo, "hombre de más traza y portẹ que pide el arte», según se consigna en el Tumbo (libro del monasterio de Santa María de la Espina, en Valladolid) y cuenta Guillén de Robles en su folleto, trabajó en la cerrajería de este monasterio, como también en el remate de una cruz con su bola, colocada sobre el tejado de la capilla de Santa Catalina, habiéndosele satisfecho por ella 341 reales, según partida consignada en los bienes dejados al fallecer dona María de Castro, esposa de D. Antonio Cabeza de Vaca (Marzo, 1608).

JuAn del BARCo hizo varias obras en el monasterio de San Pablo, de Valladolid, y en el palacio, mediante encargo de los Duques de Lerma, figurando entre otras partidas ocho balcones, dos rejas para capillas particulares de la iglesia de Santa María la Real de las Huelgas, en Valladolid, el año 1616, consignando en el documento, fechado el 14 de Septiembre, que habían de ser iguales en labor y peso, colocándose en el remate central entre varios adornos "la Coronación de la Virgen", debiendo terminar la obra el día de San Juan, en Junio del an̂o siguiente de 1617, cuyo proyecto fué dibujado por el arquitecto Francisco de Praves.

Obligóse Juan del Barco, mediante compromiso, a hacer las dos rejas citadas, según esta cláusula: "llorente medina testamentario de doña lucia de zabalga... y $\mathrm{m}^{\circ}$ de mediano testamentario de $\mathrm{D}^{\mathrm{a}} \mathrm{M}^{\circ}$ Ruiz... enterrados en las capillas q' tienen en el monasterio de las Guelgas... y de otra parte $J i^{\circ}$ del Barco maestro de hazer rexas digeron q' el dho $\mathrm{Ju}^{\circ}$ del Varco haya en cada una de las dos capillas una Rexa de la misma traça, lavor y peso con las siguientes condiciones:

"Cada Rexa y sus balaustres y su lavor á de ser de dos ordenes y de diez y seis tercias de largo ambas ordenes... desde los diez y seis pies an de començar la coronacion y los demas adornos y lauores... toda la lauor ha de ser conforme á la traça q' ha hecho para ello francisco de praves architecto... ademas escudos de cada una de las armas q' le diere cada uno de los testamentarios acauadas para el dia de San Juan de Junio de.1617.»

Anteriormente a Juan del Barco, por documento fecha 1597 , se le encomendó el trabajo de la reja de hierro para la capilla del doctor Luis de Mercado, médico de Cámara, destinada al monasterio de San Pablo, de Valladolid, bajo las condiciones insertas en el protocolo de D. Pedro de Arce, que entresacadas dicen: "que se haya de hazer la dha obra de la 
Rexa conforme á la traça... y las molduras q' fuesen á la parte de afuera ayan de yr por la parte de adentro... y se haran los escudos y remates... y las armas y lo labrara de medio Relieve todo lo q' fuere armas y las targetas con sus Revoltones y esto y todo lo demás á de yr muy bien acabado y labrado á martillo y lima... y las molduras mny derechas bien corridas, labradas y cinceladas.

"El maestro q' desta Rexa se encargare la llevara á la misma capilla do se a de asentar y la asentara sobre sus pedestales de piedra q' se le an de dar labrados y asentados.

"Las chapas de q' se obieren de hazer las cornijas y las demas molduras y pilares cuadrados an de ser de g'uen guierro y q' no sean mas gruesas q' el canto de un real de á ocho... todo á de ser por peso dando la parte del dho dotor mercado por cada libra de todo lo contenido en la dha Rexa á Real y cuartillo acabada para el dia de San Jacinto deste presente an̂o á contento de di ${ }^{\circ}$ de praves é conforme á un balaustre de madera torneado y otro q' esta trazado (firma) Juan del barco.»

En virtud de las anteriores condiciones se otorgó la escritura, que en términos generales copiamos del Sr. Martí, y éste apuntó del protocolo citado de Pedro de Arce, la cual dice:

"...nos Juan del barco rejero y maria osorio su mujer vezinos... decimos q' por cuanto el dotor mercado medico de camara del r'ey nro señor tiene en el monasterio de San pablo una capilla de q' llaman de San jacinto en el claustro del en la cual estan concertados q' yo el dho Juan del barco haga una Rexa y maria osorio su mujer nos obligamos de hazer $1 .^{\circ}$ Febrero 1597 .»

También por esta época figuraba en esa capital, donde trabajó, el cerrajero de Su Majestad JuAN QUIJANo y un tal JUAN LÁzAro, cerrajero de la Reina.

Obras características de los cerrajeros españoles, fueron los puilpitos de las iglesias, verdaderos ejemplares de arte, entre los cuales merecen mención especial - a más de los consignados de Avila y Santiago de Galicia-los dos de la iglesia del Salvador, en Cortegana (Huelva), que pertenecen, como excepción de labor, al decadente período del siglo XVII; esta obra, de ignorado autor, compónese de un cuerpo octógono de elegante cornisa sostenida por artísticos balaustres, acusando inferiormente la forma semiesférica, ocultándose de este morlo los soportes por unos tallos floridos, y en el centro se destaca la Virgen rodeada de la simbólica vid (1).

(1) Véase Labarta, Hierros artisticos, I, núm. 62. 
El Santuario de Nuestra Sen̂ora de la Cinta, próximo á Huelva, guarda una preciosa barandilla elegante y de suma sencillez con entrelazados tallos decorados por hojas rizadas.

El rejero Juan Monreal, en 1613, labró un púlpito de estilo gótico destinado al santuario de Fuencisla (Segovia), unas rejas para ventanas, aldabones, veletas y otros trabajos; así como Alonso ZAMorA, el año 1647, reformó las rejas de la capilla de la Adoración de los Reyes y de Nuestra Señora de la Antigua, en la Catedral de Toledo.

También en igual fecha construyó Juan Alvarez la reja de la Puerta de los Leones, de esa Catedral, copiando a continuación el curioso recibo como resto de cuenta:

"En Toledo á veinte y siete de abrill de mil é seiscientos é quarenta é siete paresció Juan alvarez maestro de rrejeria vezino de la villa de madrid confesó haber Rescibido de la obra y fabrica de la santa yglesia de Toledo ocho mill quinientos quatro rreales y doze maravedises... con los quales y con veinte y siete mill rreales $q$ ' tiene Recibidos esta enteramente pagado de los treinta y cinco mill quinientos é quatro rreales doze maravedises q' importa la obra de la Rexa q' ha hecho para la puerta de los leones de la dha sancta yglesia la qual habiéndose pesado en presencia del otorgante y de felipe lazaro degoyti maestro mayor de obras de dha yglesia parece tubo quatrocientas y onze arrobas y diez y ocho libras de las cuales se baxaron veinte arrobas y dos libras q' pesaron los balaustres q' le dió la dha obra para la dha Rexa viniendo a quedar liquidas trescientas é noventa arrobas y veinte y una libras... q'arrazon de tres r'reales y catorce maravedises libra montan treinta y tres mill trescientos $\mathrm{y}$ treinta $\mathrm{y}$ seis rreales, mas doscientos rreales de ayuda de costa para venir a sentar las dhas rrexas".

De modo que, a juzgar por el valor material del hierro, poco percibió por su trabajo.

La reja que comunica con San Marcos y los hierros para las lámparas de la capilla de la Anunciación, en la Catedral de Sigiienza, son obra de Lorenzo Pastrana (1622), como también los herrajes de la cancela de la puerta principal, y de Francisco Martíxez los grandes clavos de bronce para la mencionada puerta, hechos el an̂o 1626 , que fueron costeados por el Cardenal Zapata, y más tarde, en 1670, el rejero bilbaíno Francisco LAGúnez construyó la reja para la capilla de Nuestra Señora la Mayor.

Sin alarde de trabajo, dado el precario período porque atravesaba la rejería española a mediados de la decimoséptima centuria, hemos de citar la reja del altar mayor de la Catedral de Sigiienza, que el Cabildo en- 
cargó al vascongado Domingo Zialceta, vecino de Madrid, no sin antes haber pedido precios y condiciones a otros rejeros, cuya bien ejecutada obra, de severo aspecto, terminó en 1633, excepto el remate de ella, que hubo de colocarle el rejero JUAN RoDRíGUEz, representando el grupo del Calvario, siendo costeado por el Obispo de Sigiienza, D. Pedro González de Mendoza.

Con la colocación de esta reja requeríase hacer otra para el coro, como así se verificó cuando la situación económica de la fábrica pudo permitirlo, comisionando a Zialceta, en unión de Francisco Martínez, para ejecutarla, como lo hicieron, colocándola en 1649 , si bien hemos de reconocer es de menor importancia que la del altar mayor, importando 70.000 reales, satisfechos por el prelado dominico Fray Domingo de Tapia.

JUAN DE ARRILlaga trabajó en varias obras de la Catedral de Burgos, en 1679 , e hizo la magnífica reja del crucero en el santuario de la Fuencisla (Segovia), cuyos gastos fueron satisfechos por el gremio de cardar y apartar, según aparece en una inscripción.

A pesar del estado decadente de esta industria, fué muy celebrado en Sevilla el rejero y relojero SEbastián Conde, natural de Almonte, que en 1692 construyó la cruz de hierro conocida con el nombre de la Cerrajería, en la calle de la Sierpe; construyóse a expensas de los vecinos de esta calle, y mereció elogios de los artistas más notables por sus adornos calados y esmerada ejecución.

El Sr. Gestoso, hablando sobre el particular, la detalla en estos términos: « La Congregación del Santísimo Rosario condujo procesionalmente la cruz en un carro con la mayor decencia, desde las gradas de la iglesia al sitio de la plazuela de la Cerrajería, donde permaneció con culto y devoción...; pero al verificar la entrada el Rey Felipe V, en 1729, hubo necesidad de ampliar el tránsito, quitándose la cruz; pero liasta el año 1734 no se volvió a colocar, quitándola posteriormente para depositarla en el Museo Arqueológico de Sevilla, donde hoy existe» (1).

Aun cuando pertenece al mal gusto de la época, revela, sin embargo, en sus característicos trazos barrocos cierta fineza en la labor, construída con relativo esmero, excepto en las figuras de los cuatro Evangelistas, incorrectas de dibujo, colocados cada uno en un ángulo del pedestal.

Si mal no recordamos, también a él se debe el magnífico balcón de la casa sen̂orial de la calle de O'Donell, en la misma ciudad, trabajo de herrería artística muy celebrado y verdaderamente notable.

(1) Diccionario de artifices sevillanos, II, pág. 363. 
También es obra de Conde la preciosa llave de la sala del Patronazgo del Archivo de Simaneas.

Existe en la capilla de Santiago, en la Catedral de Burgos, una magnífica reja, obra de BARTOLOḾ́ ElgoIVAR, hecha en 1696, apoyada sobre pedestales de jaspe y elevándose hasta la clave de la ojiva, en cuyo remate se halla el Santo titular; fue dirigida por el maestro Vallejo, que también hizo la del crucero. No debemos omitir entre las de este período las buenas rejas de la Catedral de Segovia, del presbiterio y coro, coronadas por muy airosos grupos de azncenas, con cierto carácter realista, que hasta a esto llega en el arte de aquel siglo.

Como se ve, aunque llamemos decadente a este siglo comparado con el anterior, se observan en él los esfuerzos de los maestros del hierro, haciendo lo posible por sostener el mérito de sus obras, si bien no llegaran en ellas a la altura de los pasados, sin faltarles por eso marcado carácter de época y dominio de la materia con que las construían.

Otros obJetos DE hIERRo DEL SIGLO XVII.-Continuaron haciéndose cofrecillos y cajas fuertes en esta época, con paramentos recortados y grabados, afines a los cuales aparecen los bargueńos o arquimesas, completados en su exorno con la aplicación en sus tapas de caladas chapas de hierro, para recibir sus típicas cerraduras, tiradores, escuadras y pasadores, que hacían destacar sobre fondos, de tela roja o carmesí, con el fin de obtener mayor efecto. Muchas veces eran colocadas estas cajas sobre mesas con curvos herrajes, que tanto servían de refuerzo como de decoración en ellas, igualmente que en otros muebles de madera, como armarios, facistoles, arcones y vasares, en los que la combinación del hierro con la madera completaban un artístico conjunto.

Rama independiente de la rejería, pero considerada como complemento de la cerrajería o herrería, son las tenazas de hacer hostias; los troqueles para la fabricación de medallas y monedas; hierros para estampar adornos en tapas de Códices, y cuantas labores tienen por objeto el cincelado en hueco, mereciendo los plácemes muchos artífices espan̂oles que, por su fama y esmerado trabajo, llegaron a constituir una escnela en Madrid, en los siglos XVII y XVIII.

Entre los fundidores citaremos, aun cuando fuese alemán, a NICoLÁs Biz, por haber obtenido discípulos tan aventajados como Alonso Martínez y Luis Santos.

Los objetos que construyeron en este periodo, fueron múltiples y variados, en especial de uso doméstico, como las parrillas giratorias, cade- 
nas pára colgar ollas en los fogones, tenazas, pinzas, palas de cocina, muy originales y artísticos algunos, procedentes de cocinas de pueblos fronterizos con Portugal, en la provincia de Salamanca, y que servían de adorno a la vez en los hogares de las casas de campo, dispuestos a guisa de vasares, labrados de finas volutas de hierro, para colgar sartenes, cucharones, horquillas, etcétera.

En el fondo del hogar pendían cadenas adornadas, que remataban en un gancho fuerte, donde colgaban calderas, colocando también unas robustas chapas forjadas para evitar se quemase el muro, siendo la que damos copiada del natural, procedente, tal vez, de algún castillo, conservada en el Museo de Barcelona.

Forman, además, parte del ajuar los trípodes para sostener peroles u otras vasijas, habiendo unos aparatos a modo de hacheros, como algunos del Arqueológico municipal de Barcelona, formado con hierros horizontales y verticales, en cuyos extremos aparecen receptáculos para sostener utensilios de cocina, pero más factible es fuese para alumbrado litúrgico, fundándonos en tener una cruz central, $y$ en que las palomillas laterales bien pudieron servir para colocar vasijas con aceite, destinadas a hacer arder la mecha.

Los morillos de cocina adquirieron variadas formas en relación al siglo anterior, simulando caprichosos animales o retorcidos objetos, típica labor de los herreros castellanos, salvo determinadas excepciones, compuestos también por una barra vertical, redonda $u$ octógona, de la que surgen nudos y hojas provistas de ganchos para sostener el asador; existen curiosos ejemplares en Barcelona, habiendo además originales modelos en la colección de hierros del Sr. Rusiniol y en el Museo diocesano de Vich.

Empleábase las chafetas o braserillos, lisos o repujados, aplicados también a usos litúrgicos desde el siglo XIV, destinados a caldear los pomos de latón y calentarse las manos los sacerdotes que habían de permanecer en el altar durante los Oficios divinos, según opinión de Mosén Gudiol, actual director del Museo de Vich, en su Arqueología Sagrada.

Corresponden a este período las palmatorias arandeladas de arcos so- 
brepuestos unidos a la arandela, para colocar en ellas antorchas o vasos a modo de lámparas, y los candiles más ornamentados que en la época anterior.

Entre el mueblaje privativo del hogar, como labor del cerrajero, merece fijarse la atención en el curioso estante de hierro forjado, procedente de la provincia de Salamanca; ejemplar notable de menuda labor, motivada por la combinación feliz de la voluta, resultando elegante al ser suspendido, como se ve en el Museo de Barcelona, hallándose en la parte inferior pendiente de sus garfios útiles de cocina.

Producto del arte castellano del final de este período son las romanas, trabajadas esmeradamente en hierro y latón, de formas elegantes; tal sucede con la procedente de la Casa de la Moneda, de Madrid, adquirida por el Estado, de la Superintendencia de la misma; obra cincelada con delicadeza suma por el maestro SALINAS, según aparece firmada, tal vez

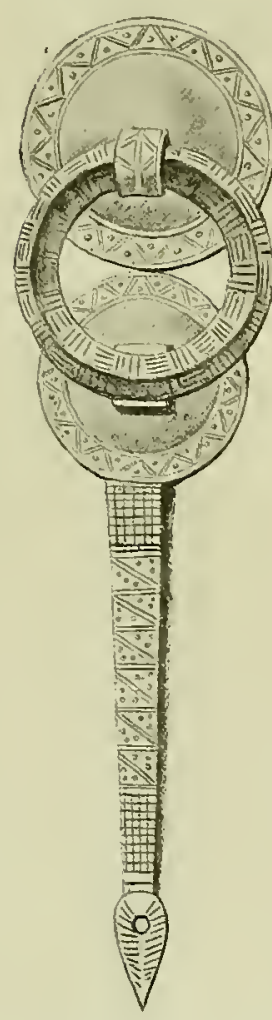
única en su género, que admiran los inteligentes al visitar el Museo Arqueológico Nacional.

En el mismo Museo existen algunas cerraduras, una de las cuales tiene en chapa el escudo de la Inquisición, y procede del Monte de Piedad de Madrid, leyéndose en la inscripción: "Fecit JuAN Noreña Montero, 1624». Pertenece probablemente a la misma puerta la chapa con calados, que ostenta en la parte superior una cruz, una daga y un perro, leyéndose debajo el nombre de Pedro Chao, 1688, seguido de una cruz. También hay otra cerradura con llave de cañón triangular, que estuvo colocada en la iglesia del Pilar, en Zaragoza.

La predilecta labor de los aldabones continuó como en el siglo XVI, pero adoleciendo de escaso gusto artístico, aun culando consistían también en los consabidos discos calados, de los cuales pendía del centro la argolla robusta forjada, que decoraban con dentados o arcos de círculo rodeando el contorno; el croquis adjunto del original, existente en el Museo municipal de Barcelona, puede servir de ejemplo; también el de la puerta de entrada del Hospital de Barcelona, y el que se halla colocado actualmente en la puerta del palacio de los Condes, de la misma ciudad, hoy Archivo de la Corona de Aragón, son muy notables. Estos ejemplares, comparados con los de la pasada centuria, sobresalen entre los demás de su tiempo por la pureza de sus líneas.

EI curioso investigador, y mejor aún el arqueólogo, advierte que los 
aldabones de las puertas, en la parte Norte de España, tienen un carácter especial muy semejante a los de arte aragonés, pues constan de un rectángulo calado o festoneado alrededor, con su crestería y pilastras laterales, simulando una portada, de la cual pende mana figura o un animal, en sustitución de la rodaja para golpear. Revelan además la nueva fase de este trabajo de los cerrajeros aragoneses desde fines del siglo XVI, las varillas retorcidas, acompañadas del rojo paño, al través del cual se destaca el calado.

La industria de la cuchillería adquirió gran preponderancia desde el siglo anterior, en que comenzaron a emigrar a América oficiales cerrajeros, mereciendo citarse la tijerería entre los diversos ramos que aquélla comprende, de la cual salieron hábiles maestros españoles que se dedicaron con verdadero afán a este excepcional trabajo, al contemplar la filigrana de sus preciosas labores, sobresaliendo los centros industriales de este género en Albacete, Chinchilla, Alcúzar de San Juan, Toledo, Madrid y Santa Cruz de Mudela, ésta como especialista en acicates y tenazas con quijadas para cortar.

Fue muy usual poner el nombre del autor y fecha grabada al terminar el trabajo, especialmente en las ciudades de Valencia, Serilla, Jútiba y Eguí (Navarra). De estos objetos de cuchillería y tijerería era muy notable la colección de nuestro difunto amigo Sr. Rico Sinobas, que hoy posee el Arqueológico Nacional, pudiendo el aficionado consultar en la revista Historia y Arte cuanto manifiesta D. Manuel Rico sobre "Cuchillería española», ilustrado con muy buenas láminas de todo ello.

También ofrecen singular trabajo los marquitos de hierro, a veces combinado con el latón, para los retratos de miniatura y reliquias, de gran precisión en su ajuste y de los que se encuentran muy esmerados ejemplares debidos a la habilidad de los herreros madrilen̂os. 


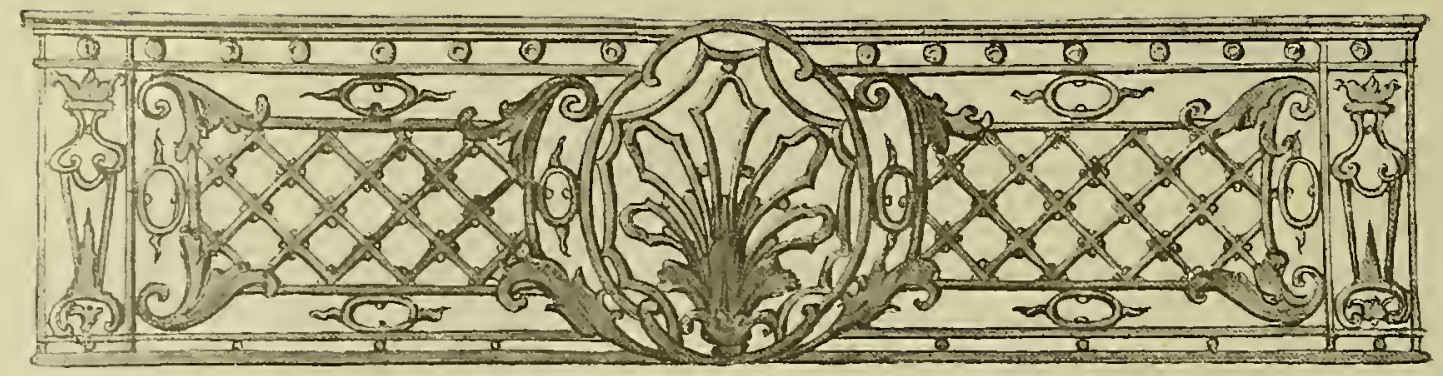

\section{E POCA QUINTA}

\section{Barroquismo.}

El estilo barroco, que imprimió a la ornamentación un sello especial, no pudo menos de influir y aplicarse también a la rejería, prevaleciendo durante todo el siglo XVIII, y dando lngar a una serie de obras de gran originalidad entonces, y con universal agrado aceptadas.

Desarrollado en Italia, y más especialmente en Francia, de aquí vino a nosotros con los Borbones, que lo implantaron en importantes construcciones, muebles y en torlos los enseres de aplicación para la vida.

Sencillo realmente en su ejecnción, obtuvieron, sin embargo, los rejeros muy agradables efectos, gracias al movimiento y combinación de sus líneas. en cnanto evitaseu la monotonía o paralelisno entre ellas, en consonancia con el gusto de las construcciones, muchas veces rodeadas de jardines, cerrados a su vez por verjas suntuosas.

Influída nuestra Península por el arte francés de los fastuosos palacios de Versalles y Trianón, hallamos su recuerdo en las rejas de San Ildefonso, Aranjuez y otros reales sitios, incluyendo las madrileñas de las Salesas, El Pardo o Buen Retiro, hoy en la Escuela de Veterinaria, de marcado gusto trancés, pero compitiendo con sus originales, aunque debida su ejecución por lo general a manos de rejeros españoles. A esta época corresponden también muy típicas barandillas de escalera, rejas oraladas de rentanas y curvos balcones, que adornan injosos palacios de gusto barroco entre nosotros, como los hierros tan notables, por la belleza de sus líneas y carácter armónico con la fachada, del suntuoso palacio del Marqués de Dos Aguas, en Valencia. 
A principios de siglo, el valenciano Gaspar Monsés proyectó la magnífica reja del coro de la Catedral de su patria, según consta en documentos de la misma iglesia, y el cerrajero sevillano JuAN Gunzález recibió en 1702 la cantidad de 319 reales por doce botafuegos de compañía, serpentinas y unas tijeras grandes para cortar cartuchos.

De esta época datan el púlpito, las vulgares rejas del comulgatorio y la circular, colocadas en la fachada de San Ginés, en Madrid, de la calle de Bordadores, que hizo el cerrajero Eugenio GÁlvez, como también es de su mano la falleba, cincelada con esculturas, que los maestros herreros de la corte mandaban copiar a sus oficiales en cera, barro, o simplemente en dibujo, por ser obra de mucho ingenio, representando un perro, forjado en todo relieve, el cual servía de manilla para el cierre de puerta de la iglesia de la Trinidad, en Madrid, ignorándose su actual paradero.

Por mera curiosidad, dispensada por el buen deseo de dar cuenta de todo lo relacionado con las obras de cerrajeros, hemos de mencionar algunos nombres de maestros que labraron herramientas en España: tal acontece con SALIsas, autor de la romana antes citada, que vivió en Toledo, y se le supone constructor de instrumentos presentados al Tribunal de la Inquisición de Cuenca para castigos y tormentos; Diego Vextura, madrilen̂o, que hizo herramientas, arcabuces, e inventó la lima giratoria para ajustar en las llaves de chispa la piedra Ilamada nuez.

JuAn de Aguas, cerrajero y relojero de Guadix, fue notable por la terraja de mano para tornillos pequeños; N. Gallardo, Istdoro SoLer, el zaragozano Juan Puerto, Francisco Morales, Carlos Montargis, el maestro LoReszo y otros, figuran también en este tiempo.

Aun cuando es copia del modelo inglés Raursden, la complicada máquina de dividir, que se hallaba en el Conservatorio de Artes de Madrid, por el perfeccionamiento y ajuste de su complicado mecanismo, merecen elogio sus constructores, Ios hermanos Rostreaga.

Fray José Cordero (1717-1797), natural del Puerto de Santa María, fue herrero y relojero celebrado en Andalucia; de su mano son la reja de hierro para la capilla de San Pedro, en la Catedral sevillana; el reloj de torre de la misma iglesia, admirablemente construídas sus piezas y perfecto mecanismo, debido a la exactitud de aquéllas, y otro reloj para la torre del convento de San Francisco, en la citada cindad.

Guarda el Museo Arqueológico Nacional una elegante falleba artísticamente cincelada en hierro, que perteneció a la puerta tel extinguido colegio de Jesuítas en Alcalá de Henares, labrada y firmata por BLAS Mansilla, el año 1724, en Madrid. 
Aparece en 1737 el maestro de los Alcázares, LuIs Rudríguez, cediendo a su hijo Dionisio las obras que tenía o de que estaba encargado, por no poderlas atender, debido a su avanzada edad, aunque con título de maestro herrero de los Alcázares de Sevilla, fechado en 16 de Agosto de 1737.

Pedro Pastrana, hermano de Lorenzo, labró en 1738 los artísticos herrajes de la cancela de la puerta de la Catedral de Sigiienza, estando las fallebas, visagras y pasadores cincelados con maestría, por lo que percibió 5.000 reales más una gratificación, abonada por el Cabildo, en virtud de lo esmerado de la obra. Pastrana fue educado en la Escuela madrilen̂a creada por Alonso Martínez, la que si bien simplificó la labor por las aplicaciones mecánicas y re la fundición, privó a las obras de aquel mérito especial que les daba el ser hechas en todo a mano.

Observando el período decadente de la rejería, el prelado español Cardenal Infante D. Fermando, trató de rehabilitarla, especialmente en Sigiienza, consiguiéndolo en parte, a semejanza le lo hecho por el Obispo de Salamanca a principios del siglo XVIII. Buena prueba de sus resultados fueron las rejas del coro de la Catedral salmantina y todo el balconaje cle la gran Plaza Mayor, notable por la gallardía de sus líneas y perfección de su montaje.

Manuer SÁxchez, seguntino, construyó las rerjas y portada del atrio de la Catedral de Sigiienza (1790), haciendo notar el Sr. Pérez Villamil la circunstancia de que, al finalizar el siglo décimoctavo, Sigiienza contaba con hábiles herreros, que eran a la rez relojeros, entre otros Manuel GuTIÉrREz (1760), relojero del Cabildo, quien tenía a su cuidado el reloj de la Catedral, y fué inrentor de unas máquinas para construir ruedas de los mismos; Antonio Gutiérrez (1780), padre de Juan Francisco, herrero y relojero, arcabucero y director del Parque de Madrid en 1820, por el alcance y construcción de cañones de escopeta, que competían con los ingleses. De él se cuenta una anécdota a propósito de su habilidad, motivada por haber enseñado a Gutiérrez la reina Amalia, esposa de Fernando VII, una aguja inglesa de coser, lamentándose de la imposibilidad de lograrlas tan finas en España, pues, dadas sus aficiones al bordado, las mandaba traer de Inglaterra. Sin inmutarse el maestro, rogó a la reina le dejase una aguja para examinarla, y trauscurrido un relativo corto espacio de tiempo se la devolvió, mostrando a la vez la ejecutada, y celebrando la reina su perfección; pero quedóse sorprendida al oirle decir: «esa pieza que Vuestra Majestad tiene en la mano no es la aguja, sino el alfiletero que la guarda».

Del siglo XVIII citaremos la reja de mna iglesia en Jerez de la Fron- 
tera, de estilo barroco, pero del mejor gusto en su género; unas rejas de bronce en el coro de la iglesia de San Pablo, en Zaragoza, obra del maestro Puch, y las barandillas de la Vía Sacra y reja de Nuestra Señora la Mayor, en Sigiienza, de construcción ya meramente industrial.

Abundaron en los siglos XVII y XVIII los balcones corridos para dos o más huecos, con barrotes retoreidos, que tienen el doble objeto de obtener mayor resistencia y variedad, sostenidos por repisas con caprichosos adornos de hierro forjado en láminas de palastro, colocando, para mayor seguridad en la balanstrada, a más de contribuir mejor al efecto ornamental, montantes unidos al muro que rematan en caprichosas formas o animales quiméricos alados.

Peregrinas llaves se encuentran en esta época, cinceladas, caladas y grabadas, especialmente las que se hacian como prueba de suficiencia por el gremio de cerrajeros, aprendices y oficiales, para ascender en grado superior si por su pericia lo estimaba así el tribunal. Estas obras de pasantia revelan adelanto, segín lo demuestrau varias conservadas en el Museo municipal de Barcelona, como también el grado de perfección conseguido en el estuche de tijeras y alfiletero cincelados, que son nn verdadero primor de ejecución, y se conserran en aquel establecimiento.

Continúan en este período los hiernos de cocina, más sencillos de forma y con menos arte; los candiles de cuatro picos o mecheros provistos de la candileja y el retorcido garabato para colgarle, muy semejantes a los del siglo anterior; las tenazas para la fabricación de hostias; Ios collares o carrancas para los mastines, construídos ingeniosamente por los herreros, mediante chapas combinadas y púas con objeto de defenderles de los lobos, algunos existentes en el Museo municipal de Barcelona; como también el grillete y carcán, instrumentos de suplicio; siendo de igual procedencia la barandilla de hiemo forjado, con follajes repujados, del presbiterio de la extinguida iglesia castrense de la exciudadela de Barcelona.

El arte catalán, que tuvo un carácter peculiar en anteriores centurias, influído indudablemente por el del Mediodía de Francia, se nntrió a principios del XVII con elementos neo-clásicos aceptados en el arte castellano, y desde el siguiente siglo procedió como unido más estrechamente con el del resto de España. 


\section{SIGIO XIX}

En nuestra época son innumerables los objetos de hierro que se construyen; los herreros se valen la mayor parte de dibujos facilitados por arquitectos o tomadas de publicaciones extranjeras, constituyendo la producción más general las ejecutadas en talleres de fundición artística, habiendo progresado este género de un modo notable gracias a obtener reproducidos los modelos con finura, especialmente cuando se emplea el procedimiento de la cera perdida, que acusa con mayor exactitud hasta los más nimios detalles.

Hoy, sin embargo, el hierro forjado vuelve a adquirir su estimación de siglos anteriores, desde la centuria pasada en verdadera decadencia, sucediendo en España igualmente que en el extranjero.

Las obras hoy construídas resultan de relativa facilidad, en virtud de poder adquirir hierros con los gruesos o formas admitidas en el comercio y la industria, elaborados en fábricas mecánicamente a gusto del consumidor.

Como esfuerzo humano en la Metalistería, se notaron los ejemplares exhibidos en la última Exposición Universal de Barcelona, donde cada cual aportó sus adelantos, laudables por la idea de la originalidad, a la vez que demostraron el cultivo de una industria que resurgía de nuevo.

Varios son los herreros españoles, actualmente llamados constructores, que en gran escala mantienen su empresa, ora comercial, ora industrial, con visos de arte, entre los que figuran González e Hijos; la Casa Vallarín, de Barcelona, invadiendo con sus obras la Península y llegando al extranjero, siendo dignas de citarse las rejas del Palacio de Justicia de la Ciudad Condal e infinidad en casas particulares, balcones, candelabros y pies de aparatos de alumbrado público eléctrico para la misma ciudad; el industrial Cristóbal Rosell; el no menos conocido Santamaría, establecido en la capital catalana, aun cuando sus apreciados trabajos son extensivos al bronce y el cobre; y, por último, la Sociedad Masriera y Campins, hoy disuelta, altamente conocida como fundición artística, pero no menos notable por sus trabajos de forja y cincelado, de un g'usto y arte que llaman la atención de los inteligentes; díganlo las rejas de puerta construídas en hierro forjado que salieron de sus talleres.

En las "Resoluciones capitulares de los an̂os 1800 a 1814 del Cabildo de Barcelona», existe un documento, consignando en 1800 que proceda esta Corporación a la venta del hierro viejo de la reja antigua de la capi- 
lla de Santa Eulalia. Curioso es también que el año 1862 el señor Arzobispo Cardenal de la Puente hiciese un proyecto de su mano de una reja que comunicaba su palacio con la Catedral de Vitoria, siendo construída esa obra en dicha ciudad.

Existe una reja moderna que llama la atención en Barcelona, simulando cables retorcidos con sus nudos, cuyo trabajo parece de fundición, cuando en rigor, es forjado, y que debió consegruirse con frecuentes caldeos; esta labor ingeniosa, a la vez que de mérito, se halla en el edificio del Centro de Crédito Catalán, instalado en la calle Ancha.

Juan González, vecino de Madrid, construyó, entre otras obras de rejería, las diez preciosas y notables rejas para otras tantas capillas de la iglesia de San Francisco el Grande, en la corte, según dibujo proyectado por el arquitecto Sr. Farrés, trabajo delicadamente concluído, forjado y cincelado. Un hermano del dicho González, residente también en Madrid, hizo varias rejas y trabajos celebrados, entre las que citaremos las puertas-rejas de entrada al Banco de España y del.Hispano-Americano de Madrid, en la calle de Sevilla, e infinidad de obras para casas particulares y establecimientos.

Se han distinguido también en Madrid como rejeros José Callejo, Tonis de Mrguel, que después de ser maestro cerrajero marchó a Francia para aprender ciertos procedimientos técnicos, entrando en una fábrica como peón, ascendiendo en el oficio y permaneciendo allí hasta que satisfizo su deseo; Víctor Esteban, que trabajó en las obras reales y es constructor de las rejas del Palacio de Zabalburu, proyectadas por el arquitecto Lema; VAllejo, también del Real palacio; JuAn de Doupedro, Asíns, Prinetri y, finalmente, entre otros, Eugenio Marinas, constructor de muchas y excelentes obras de rejería artística, tales como la verja y candelabros del Monumento a los Bomberos de la Habana, proyecto del arquitecto Zapata; puertas de cerramiento y escalera de la casa del arquitecto Latorre; las proyectadas por Urioste para la casa calle del Barquillo y Credit Lyonnais en la de Alcalá; caballetes para los dibujos en la sala de Haes del Museo de Arte Contemporáneo. y rerja del palacio del Marqués de Linares, de Alrarez; rerja del panteón del Marqués de Vallejo en el cementerio de San Isidro, proyecto de Fort; verjas de las capillas de la cripta de Nuestra Señora de la Almudena, proyectos de Repullés y Moya, y otras de importancia técnica y artística.

No faltan tampoco nombres que citar en otras poblaciones, tales como Críspulo Avecilla r RoJo, en Toledo; Vajentix Vélez, en Burgos; Marcelito Escotar, en Salamanca; Matías Abad, en 'T'eruel, y otros en 
Zaragoza, Sevilla, Valencia, etc.; cuyo número aumentará sin duda, dado el resurgimiento que al presente se opera en esta labor artística; comienza la rejería a adquirir gran importancia en la construcción moderna, pues al aplicarse a ésta principalmente el hierro y sustituir con cancelas y puertas gran parte de las hechas antes en madera, por la ventaja de su diafanidad, van aplicándose, tanto sus trazadores como sus ejecutantes, al estudio de las obras antiguas, que tratan de reproducir o imitar, al menos en sus estilos, aunque aplicando más modernos procedimientos.

Tanto en Madrid, como en Barcelona y otros puntos, se construyen al presente muy notables rejas de toda especie, singularmente con carácter medioeval y francés barroco, más generalmente aceptado, pudiéndose citar en Madrid, a más de las consignadas, muchas otras con que se cierran los más suntuosos hoteles y jardines que en la actualidad se construyen. De desear es que, continuando la senda emprendida, llegue a la mayor originalidad y perfección esta rama del arte que entre nosotros cuenta con tan gloriosos precedentes.

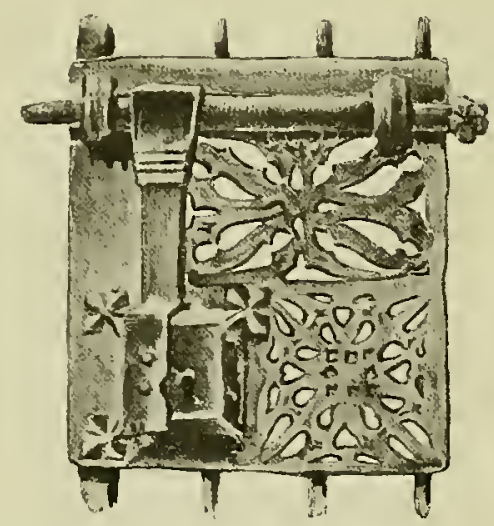

De una reja en el claustro de la Catedral de Barcelona. 


\section{INTDIOF OROINOIOGICO}

DE LAS OBRAS MÁS NOTABLES CITADAS EN ESTE ESTLDIO, CON EXPRESIÓN DE SUS AUTORES

- SIGLO XIII -

Rejas de Nuestra Señora de París.
Reja de Santa Eulalia. Catedral de Barcelona. . 1384 Bartolomé Desplá.........

\section{- SIGLO XV -}

Reja del presbiterio de la Catedral de Tarra-

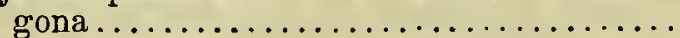
Idem del púlpito de ídem de Barcelona.......

Idem de las Reliquias de la Catedral de Burgos . Idem de la capilla de Santa Ana, en ídem id...

\section{- SIGLO XVI -}

Reja de la capilla de San Eugenio. Catedral

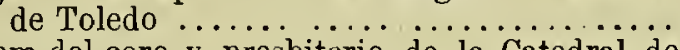
Idem del coro y presbiterio de la Catedral de Murcia.............................. Idem del coro de Santa Eulalia. Catedral de Barcelona............................... Idem del presbiterio y coro de la Catedral del
Burgo de Osma.................... Idem de la capilla de la Concepción. Claustro de la Catedral de Sigüenza.............. Idem del Hospital Real de Santiago de Galicia. Idero de la capilla de Nuestra Señora la Blanca.

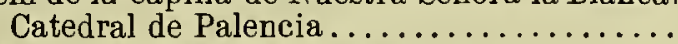

Rejas de la iglesia de Guadalupe ...........

Reja del presbiterio de la Catedral dePamplona. Idem primera lateral del presbiterio de la Catedral de Sevilla... ................ Antepecho de la escalera de la catedral de

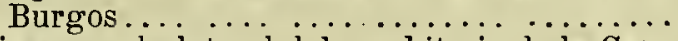
Reja segunda lateral del presbiterio de la Catedral de Sevilla.....................

Idem del coro de la ídem íd..............

Rejas de la capilla mayor de la Catedral de

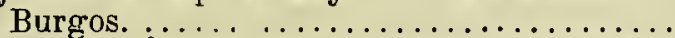
Reja de la capilla del Condestable, en la Cate-

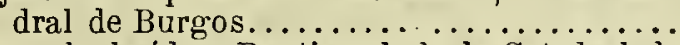
Idem de la idem Bautismal de la Catedral de

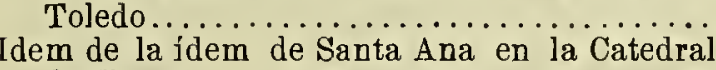
de Huesca......................... Idem de la capilla del Arcediano de Alba en la

Catedral de Salamanca. ..................
Verja del sepulcro del Obispo Anaya en la $\mathrm{Ca}$ -

tedral de Salamancu................... Sevilla............................................... Idem de la capilla de los Albornoces. Catedral

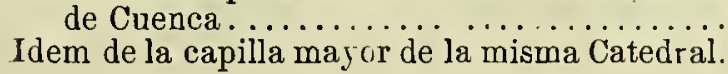

24

1250 Pagina.

17

$1438 \quad$ ? $\ldots \ldots \ldots \ldots \ldots \ldots \ldots$ 27

1443 Juan Frederic y Miguel Loquer................. 27

1496 Maestro Bujil................. 28

? $\ldots \ldots \ldots \ldots \ldots \ldots \ldots \ldots$ 31

1500 Maestro Pedro. . ........ 30

1503 Antonio de Viveros....... 30

1503 Pedro Riembau........... 31

1505 Maestro Francés.......... 30

1509 Maestro Usón ............. 31

1512 Maestro Guillén........... 56

1512 Juan Relojero............ 31

1514 Fr. Francisco de Salamanca y Fr. Juan de Avila...... 28

1517 Guillermo Ervenat......... 31 1520 Sancho Muñoz con Juan Yepes y Maestro Esteban...

1520 Maestro Hilario.......... 56

1522 Diego Udobro con Juan Cubi1522 llana y Miguel Espinosa..

1523 Fr. Francisco de Salamanca y Fr. Juan de Avila....... 28-38

1523 Maestro Esteban.......... 31

1523 Cristóbal Andino......... 54

1524 Mtro. Domingo de Céspedes. . 47

1525 Arnau Guillén.... . . . . . 32

$1525 ? \ldots \ldots \ldots \ldots \ldots \ldots \ldots \ldots$

? $\quad$ ? $\ldots \ldots \ldots \ldots \ldots \ldots \ldots \ldots$

1529 Fr. Francisco de Salamanca.. 39

? Maestro Bartolomé........ 44

1531 Maestro Lemosín ......... 57 ? $\quad$................... 21 
Reja latera] del presb. de la Cat. de Palencia... Idem de San Francisco, de Ríoseco ........... Idem del presbiterio y púlpitos de la Catedral

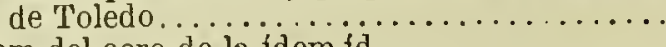

Idem del coro de la ídem fd.............

Idem de la cap. de los Benaventes. M. de Ríuseco Idem de la capilla de la Gamba. Sevilla.. .... Rejas de las capillas de San Benito y San Bernardo en la Seo de Zaragoza...........

Idem del convento de San Francisco de Ciudad.

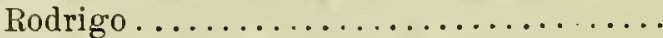

Idem de la Catedral de Cuenca. . ..........

Verja del sepulcro de San Juan de Ortega.....

Reja de la capilla de las Reliquias, en la Cate. dral de Sigüenza ....................

Idem de la parroquia de Santiago. Cáceres...

Púlpitos de la Catedra] de Sautiago de Galicia..

Reja del coro de la Catedral de Palencia.......

Idem del coro de San Benito el Real. Valladolid..

ldem de bronce, del coro del Pilar de Zaragoza.

Rejas de El Escoria].

Verja del sepulcro del Cardenal Cisneros. Alcalá de Henares. . . . . . . . . . . . . . . . . . .

Candelabros para la capilla de Santa Eulalia. Catedral de Barcelona................

Reja de la capilla mayor de Sancti Spíritus. Va-

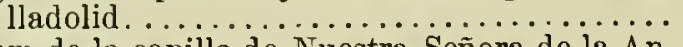

Idem de la capilla de Nuestra Señora de la Antigua. Catedral de Sevilla. Terminada en...

\section{- SIGLO XVII -}

Rejas eu la iglesia de la Magdalena, de Valladolid .........................

Púlpito de la Fuencisla . Segovia............

Reja de la capilla de Nuestra Señora del Sagrario en la Catedral de Toledo............

Idem de la capilla mayor de la Catedral de Si-

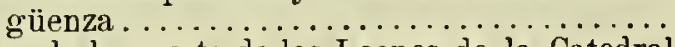

Idem de la puerta de los Leones de la Catedral

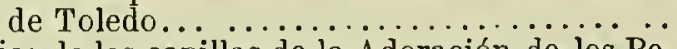

Rejas de las capillas de la Adoración de los Reyes y de Nuestra Señora de la Antigua. Ca-

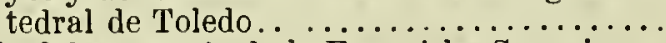
Reja del santuario de la Fuencisla. Segovia....
Idem de Nuestra Señora la Mayor de la Catedral de Sigüenza.....................

Cruz de la Cerrajeria. Sevilla.................
Reja de la capilla de Santiago. Catedral de

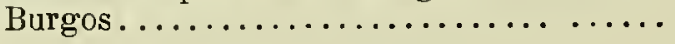

\section{- SIGLO XVIII -}

Reja del coro de la Catedral de Valencia...... Verja del presbiterio del oratorio de San Felipe Neri, en Sevilla, hoy en Santa Ana.......

Verjas del atrio de la Catedral de Sigüienza.... Reja de la capilla de San Pedro en la Catedral de Sevilla...........................
1531

1548 Francisco de Villalpando....

1548 Maestro Domingo de Céspedes con Hernando Bravo.

1554 Francisco Martínez ........

1554 Juan Méndez.............

1556 Guillén Trujallón..........

1556 Francisco Martínez ..........

1558 Hernando de Arenas . . . . . . . . .

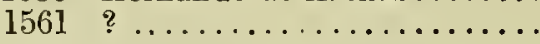

1561 Hernando de Arenas. . . . . . .

1563 Francisco Núñez...........

1563 Juan B. Celma............

1571 Gaspar Rodríguez..........

1571

1576

1579

1580

1581

1583 Alvaro de la Peña.........

1593 Juan López y Juan Barba...
1601 Matías Ruiz............ 73

1613 Juan Monreal............. 76

1607 Bartolomé Rodríguez...... 73

1633 Domingo Zialceta......... 77

1646 Juan Alvarez........... 76

1647 Alonso Zamora........... 76

1666 Juan de Arrillaga .......... 179

1670 Francisco Lagúnez......... 76

1692 Sebastián Conde.......... 77

1696 Bartolomé Elgoivar....... 78

1704 Gaspar Monsén.......... 83

1771 Juan Márquez........... 83

1790 Manuel Sánchez........... 84

1797 Fr. José Cordero........... 83

? $\quad$ ? $\ldots \ldots \ldots \ldots \ldots \ldots \ldots \ldots \ldots$

\section{$-51$} 3

3

3

76

6.

6

8

$$
\text { - SIGLO XIX - }
$$

(Véause las principales obras consignadas, páginas 86 y siguiente, en el texto a él relativo.) 


\section{INDIOF AIFABH'TIOO}

\section{de los artistas rejeros citados en esta obra.}

AGUAS, Juan de.-Cerrajero y relojero de Guadix (siglo XVIII). ............. Páginas.

ALONSO, Hernando.-Cerrajero sevillano (1534)..................... 42

ALVAREZ, Juan.-Vecino de Madrid, autor de la reja de la puerta de los Leones en la Catedral de Toledo (1646). - Otro rejero del mismo apellido se distin.

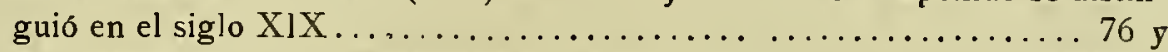

ANDINO, Cristobal.-Autor de famosas rejas en Burgos (capilla del Condestable), Palencia y Ríoseco; es uno de los más notables forjadores del hierro en el siglo XVI.............................. 49 y

ANDINO, Pedro.-Padre de Cristóbal; trabajó en Sevilla en el siglo XVI........

ARENAS, Hernando de.-Cuenca, centro artístico industrial tan importante durante el Renacimiento, patria de rejeros tan notables como Sancho Muñoz, y sin duda de Juan, Diego y Antonio de Cuenca, lo fué también de Hernando de Arenas, discipulo del primero, el cual, después de ilustrar la Catedral de su ciudad natal con rejas tan admirables como dejó en ella, trabajó también

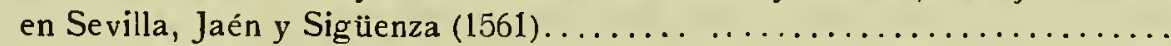

ARMOLEA o ARMAOLEA, Alejandro.-Trabajo en Valladolid bajo la dirección

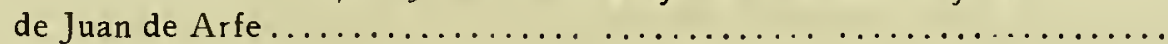

ARNAU.-Canciller en Barcelona (1494)........................ 26 y

ARRILLAGA, Juan de.-Autor de la reja de la Fuencisla, en Segovia..........

AVILA, Fr. Juan de.-Trabajó en Guadalupe y Sevilla bajo la dirección de Fray Francisco de Salamanca (siglo XVI)................. 31, 39 y

BARBA, Juan.-Terminó la reja de la capilla de ia Antigua (Sevilla, siglo XVJ) . . BARBORA, González.-Rejero sevillano (siglo XVI) .................. BARCO, Alonso.-Rejero de Valladolid (1555) ..................... BARCO, Pedro de y Juan.-Rejeros de Valladolid (siglo XVII). . . . . . . . . . . . BARTOLOMÉ, Maestro.-Trabajó en Jaén, Sevilla y Granada; autor de la reja de la capilla real de esta ciudad, reputada como una de las más notables que existen (siglo XVI)................................... 39

BLAY._París: ejecutó con Suñol las rejas de Nuestra Señora (siglo XIII)........ . BRAVO, Fernando.-Rejero de Toledo (siglo XVI)................ 50 y BU JIL, El Maestro.-Autor de la reja de las Reliquias. Cat. de Burgos (1496). 26 y

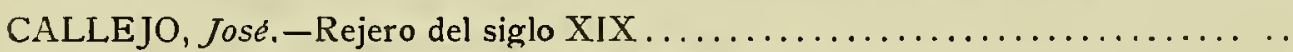

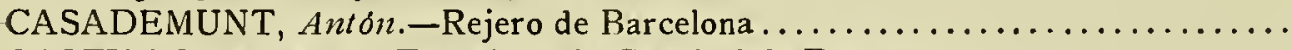

CASTILLO, Agustin. - Trabajo en la Catedral de Burgos..................

CELMA, Juan Bautista. - Rejero aragonés; autor de los púlpitos de Santiago de Galicia, de la reja del coro de la Catedral de Burgos y del de Plasencia; esta última en I604..

CELMA, Juan Tomás. - Autor de la reja del coro de San Benito el Real de Valladolid (1571) y de la iglesia del Pilar de Zaragoza..................

CÉSPEDES, Maestro Domingo. - Célebre rejero toledano; a él se deben las rejas de la Capilla bautismal, de los Reyes Nuevos y del coro, en la Catedral Primada (siglo XVl)........................... 47 y 
CONILLANA, Juan de.-Trabajó bajo la dirección de Udobro en la reja (segunda) lateral del presbiterio de la Catedral de Sevilla................... CORBELLA, Diego.-Rejero sevillano; trabajo en el Alcázar (siglo XVI). . . ...

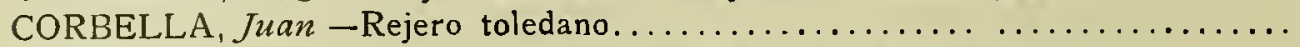
CORRAL DE VILLALPANDO, Juan._-Rejero de Palencia................. CORDERO, Fr. José. - Herrero y relojero de Andalucía (siglo XVIII)............ CUADRA, Pedro.-Diseñó rejas para Valladolid y otros puntos (siglo XVII)...... CUBILLANA, Juan de.-Artillero; trabajó en la segunda reja lateral del presbiterio de la Catedral de Sevilla, bajo la dirección de Udobro (1523)..........

CUENCA, Antonio, Diego y Juan de.-Rejeros; trabajaron en Sevilla (siglo XVI).

DELGADO, Pedro.-Autor de la reja de la capilla del Mariscal, en la Catedral de Sevilla.................................. 42 y

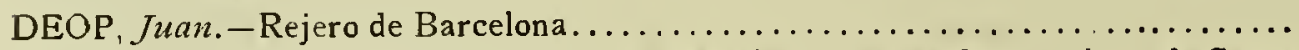

DESPLA, Bernardo.-Reparó, en 1384, una reja de detrás del sepulcro de Santa Eulalia (Catedral de Barcelona).

DIAZ DEL CORRAL, Ruy.-Cuñado de Villalpando; autor de los preciosos hierros del altar de la Virgen de la Blanca en el coro de la Catedral toledana; terminó los relieves de las puertas de los Leones, que dejó sin concluir su cuñado (1564)................................ 51

39

66

63

60

83

73

45

43

ENECO. - (Véase IÑIGO).

ELGOIVAR, Bartolomé.-Ejecutó la reja de la capilla de Santiago, en la Catedral

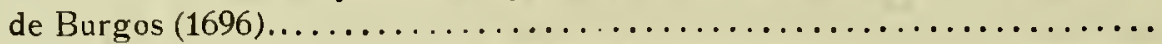

ERVENAT, Guillermo.-Autor de la gran reja del presbiterio de la Catedral de

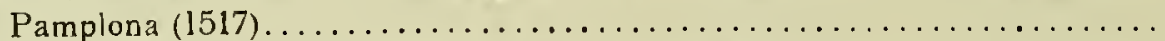

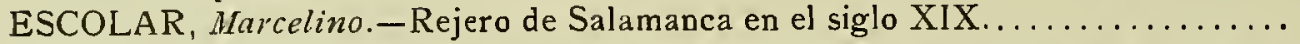

ESPINOSA, Hernando.-Trabajó en la reja pequeña de la capilla de la Antigua,

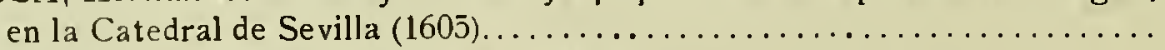

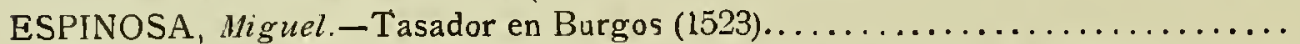

ESTEBAN, Maestro.-Autor de rejas para la capilla mayor de la Catedral de Bur. gos, $y$ trabajó en la lateral (primera) del presb. de la de Sevilla (1523). 31 y

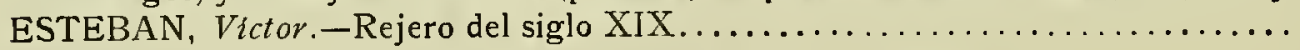

FERNANDEZ, Juan.-Rejero sevillano; trabajó en el Alcázar......... 42 y FERNANDEZ LOPEZ, Juan,-Rejero sevillano (siglo XVI)............... FIGUERAS, José. - Aparece agremiado usando el signo de la Sierra........... FRANCÉS, Juan.-Vecino de Toledo, "maestro mayor de las armas de hierro en España „uno de los más antiguos maestros de Castilla. De él se reconocen especiales obras en Toledo, el Burgo de Ossma, Sigüenza, Avila, Alcalá de Henares y otros puntos. Sus rejas de Sigüenza alcanzan la fecha de 1537. Las del coro, frente y costados de la capilla mayor en la Catedral de Avila, a que se refiere el texto, fueron deshechas, utilizándose sus trozos en varios cerramientos, como los del sepulcro del Tostado, pila bautismal, puerta

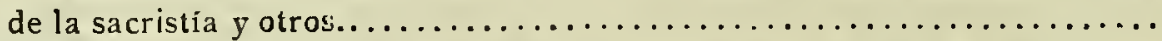

FREDERICH, Juan.-Autor de la verja del púlpito de la C. de Barcelona (1443). .

FUENTE, Jerónimo. - Relojero en Sigüenza (1547)...................

GALLEGO, Francisco.-Rejero sevillano $(1546) \ldots \ldots \ldots \ldots \ldots \ldots \ldots \ldots \ldots$

GALVEZ, Eugenio.-Cerrajero de Madrid (siglo XVIII) .................

GARCIA, Martin.--Trabajo en Sigüenza, reja de Santa Librada (1520); fué también relojero................................ 28,30 y

GARCIA, Maestro. - Trabajó en la Catedral de Sigüenza (siglo XVI) .......... 
GONZALEZ, Juan.-Cerrajero sevillano...................... 83 A otro artista del siglo XIX, del mismo nombre, se deben obras de gran

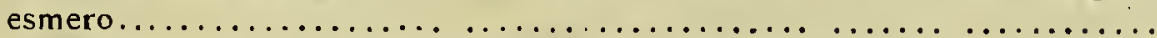

GONZALEZ, Sebastiain y Juan.-Rejeros sevillanos; antepechos en el Alcázar de

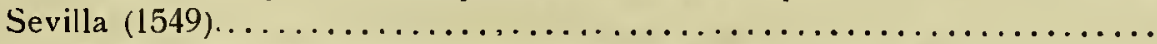
GUILLEN, Maestro. - Rejas del Hospital de Santiago de Galicia (1512)........ GUILLEN, Arnau.-De Barcelona; trabajó en Huesca: capilla de Santa Ana...... GUTIERREZ, Antonio.-Cerrajero y armero de Madrid (siglo XVIII).......... GUTIERREZ, Juan Francisco.-Hijo de Antonio; Director del Parque de Madrid

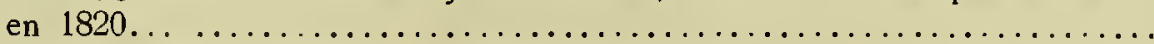

GUTIERREZ, Munuel.-Relojero en Sigüenza en $1760 \ldots \ldots \ldots \ldots \ldots \ldots \ldots \ldots$

HERREROS, Llorente.-Vecino de Valladolid; concursó para la reja del coro de la

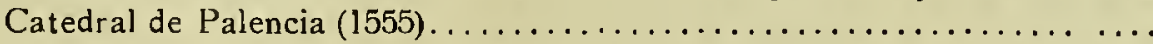

HILARIO, Maestro.-Autor de la balaustrada de la escalera de la Catedral de Burgos (1520)

IÑIGO a ENECO.-Armero en Navarra; trabajó también en la Catedral de Si-

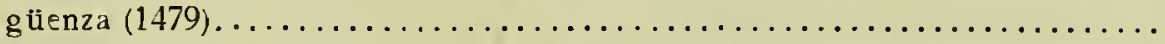

LAGUNEZ, Francisco.-De Bilbao; hizo la reja de Nuestra Señora la Mayor de

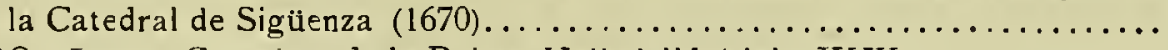

LAZARO, Juan.-Cerrajero de la Reina, Valladolid (siglo XVII).............

LIMOSIN, Maestro.-Maestro francés; ejecutó en 1531 la reja grande de la capilla de los Albornoces, en la Catedral de Cuenca, por encargo de D. Gómez Carrillo de Albornoz, tesorero y canónigo de aquella Iglesia ..............

LOPEZ, Francisco -Rejero sevillano; trabajó en el Alcázar............ 42 y

LOPEZ, Juan. - Contrató la reja de la capilla de la Antigua, de Sevilla, por escritura de $156 \bar{j}$, trabajando en ella hasta $1572 \ldots \ldots \ldots \ldots \ldots \ldots \ldots \ldots$. 43

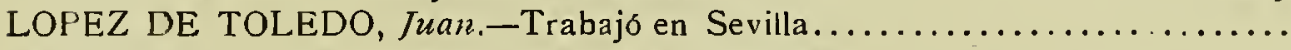

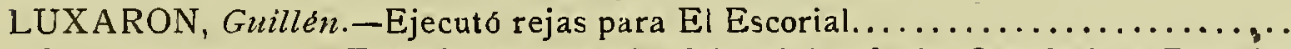

LOQUER, Miguel.-Trabajó en la verja del púlpito de la Catedral de Barcelo-

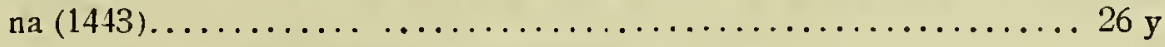

MANSILLA, Blas.-Rejero en Madrid en el siglo XVlII................

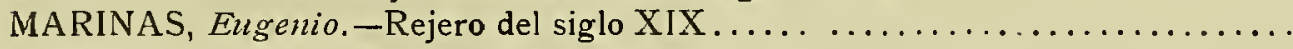

MARQUEZ, Juan. - Rejero sevillano del siglo XVIII ....................

MARTINEZ, Francisco.-Notable rejero castellano residente en Valladolid; a él se deben rejas tan suntuosas como las de Rioseco y Ciudad-Rodrigo ......... También se cita a un broncista de este nombre, que ejecuto, en 1624, grandes clavos para las puertas de la Catedral de Sigüenza..............

MENDEZ, Juan.-Rejero sevillano, autor de la reja de la capilla de la Gamba, en

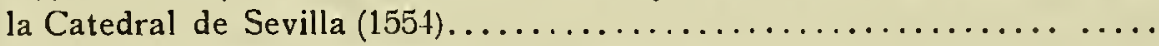

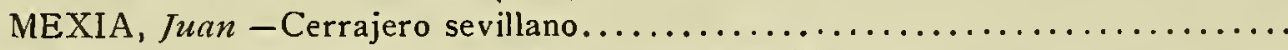

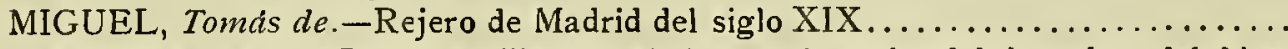

MIRANDA, Juan.-Rejero sevillano; trabajó para las rejas del Apeadero del Alcá-

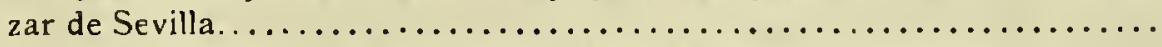

MOLINA, Antonio.-Rejero de Valladolid; yerno de Francisco Martínez.........

MONREAL, Juan.-Labró un púlpito para el santuario de la Fuencisla, en Se-

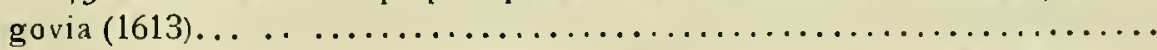

MONSEN, Gaspar.-Valenciano, autor de la reja del coro de la C. de su patria....

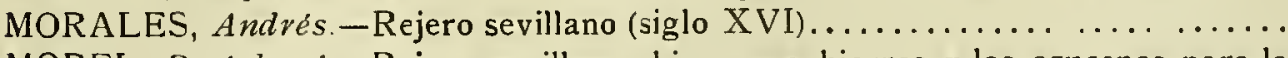

MOREL, Bartolomé.-Rejero sevillano; hizo unos hierros y las azucenas para la

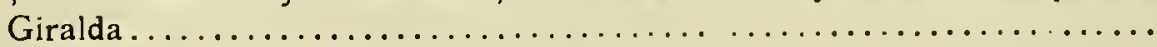


MORENO, Benigno.-De Palencia; concursante para la reja del coro de la Ca-

Páginas.

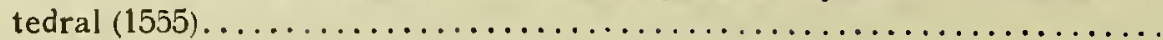

MOREY, Juan y Bartolomé.-Rejeros de Palma de Mallorca............. 23 y

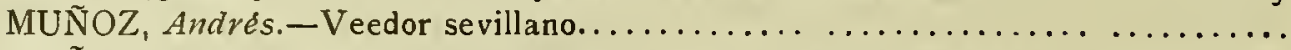

MUÑOZ, Sancho.-Natural de Cuenca; llamado a Sevilla para hacer la reja (prime. ra) lateral del presbiterio de la Catedral de Sevilla (1517).............

NAVARRO, Sebastián.-Rejero sevillano; trabajó en el Alcázar...............

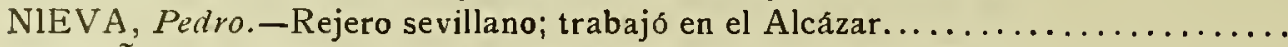
NOREÑA MONTERO, Juan._Cerrajero de Madrid (siglo XVII) ..............

NUÑEZ, Francisco.-Construyó la reja de la parroquia de Santiago, de Cáceres,

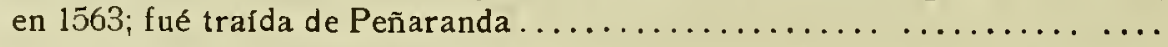

60

26

42

38

66

63

80

62

OLISARRI, Juan de.-Residente en Mondragón; concursante de la reja para el

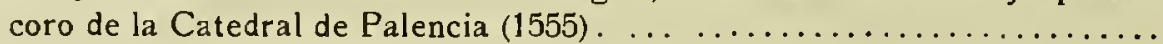

PALENCIA, Juan $B$. y Antón,-Rejeros sevillanos.................... PASTRANA, Lorenzo.-Rejero en Sigüenza $(1622) \ldots \ldots \ldots \ldots \ldots \ldots \ldots \ldots \ldots$ PASTRANA, Pedro. - Hermano de Lorenzo; labró y cinceló los herrajes de las cancelas de la Catedral de Sigüienza (1738)...............6. 61 y

PEÑAFIEL, Luis de.-Hizo las ventanas del Sagrario en la Cat. de Toledo (1608). PEDRO, Maestre.-Hizo la reja de la capilla de San Eugenio en la Catedral de Toledo (1500); concursante de la reja de Palencia (1555)........... 30 y

HEÑA, Alvaro de la.-De Valladolid; dejó sin concluir la reja de la capilla de Fabio

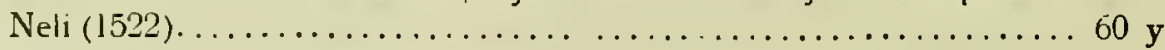

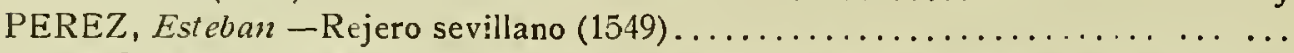
PEDRO, Maestro._Ejecutaba las rejas de la Capilia de San Eugenio en la Catedral

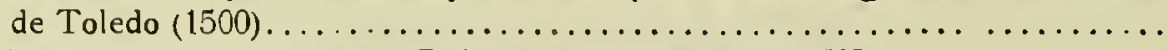

PINEDA, Antonio y Hernando.-Rejeros sevillanos (siglo XVI).............. PINEDA, Juan.-Rejero sevillano; trabajó en el Alcázar de Sevilla ....... 44 y

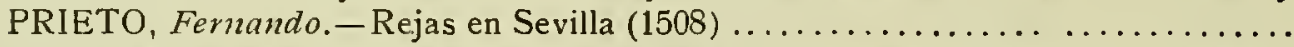
PUCH, Maestro. - Hizo rejas de bronce para el coro de San Pablo, en Zaragoza

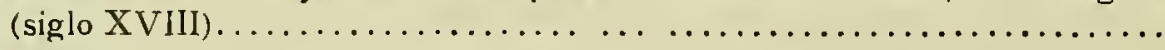

QUIJANO, Juan. - Cerrajero de Valladolid (siglos XVII-XVIII)............. 60

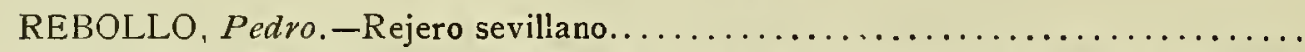
RELOJERO, Juan.-Hizo la reja de la capilla de la Blanca, Catedral de Palencia.. RIEMBAU, Pedro. - Rejero de Barcelona: coro de Santa Eulalia (1503)..........

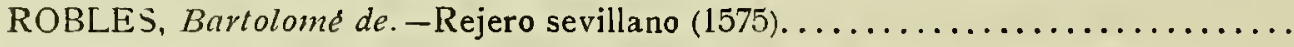
RODRIGUEZ, Bartolomé.-Autor de la reja de la Virgen del Sagrario (To-

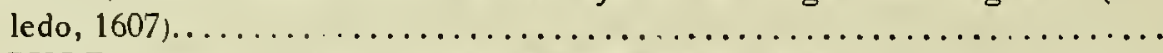
RODRIGUEZ, Luis y Dionisio.-Rejeros sevillanos del siglo XVIII............. RODRIGUEZ, Gaspar.-Terminó en 1581 la reja del coro de la Catedral de Palencia; también trabajó en Valladolid........................ 59 y

RODRIGUEZ LIBERAL, Juan.-Adicionó el Calvario que corona la reja del presbiterio de la Catedral de Sigüenza en $1638 . \ldots \ldots \ldots \ldots \ldots \ldots \ldots \ldots . . \ldots \ldots$ RODRIGUEZ, Pedro.--Reja primitiva del presbiterio de la Catedral de Sevilla... ROSTREAGA, Los hermanos. -Constructores mecánicos de Madrid (s. XVIII) . . RUIZ, Francisco. - Trabajó en el-Alcázar de Sevilla....................... RUIZ, Matias.-Reja de la capilla de la iglesia de la Magdalena, de Valladolid (si-

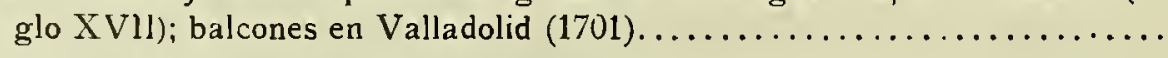

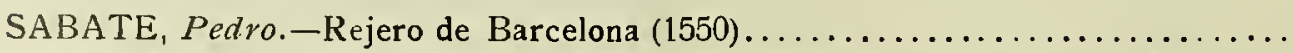
SALAMANCA, Fr. Francisco.-Notable rejero del siglo XVI, al que se deben im-
63

31

31

42

73

84

60

77

30

83

66

73

61 
portantísimas obras en Guadalupe, Burgos y Sevilla; retiróse a su patria

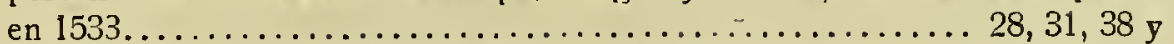

SALAS, Juan.-Rejero sevillano; trabajó en el Alcázar................... SALINAS, El Maestro.-Cerrajero de Madrid (siglo XVIII)............. 80 y SANCHEZ, Manuel.-Seguntino; trabajó en la Catedral de Sigüenza en 1790...... SAN MARTIN, Luis. -Trabajo en Sevilla (1554)...................... SEGOVIA, Rodrigo de.-Trahajó en la reja de la capilla de la Antigua de Sevilla. SENIT, Pedro.-Barcelona; candelabros para la capilla de Santa Eulalia (1581).... SERRA, Juan,-Artista agremiado cuya marca era una Sierra............... SILVA, Francisco.-Ventanas del Sagrario de Toledo $(1607) \ldots \ldots \ldots \ldots \ldots \ldots \ldots$ SIRACH, José.-Artista agremiado cuya marca era una Estrella............... SOLER, Carlos. - Artista agremiado cuya marca era un Sol................. SOLE, Bautista.-Artista agremiado cuya marca era la Tenaza............ . SORIBAS o SORRIBA, Cosme de - Trabajó con Pedro Delgado en la reja de la

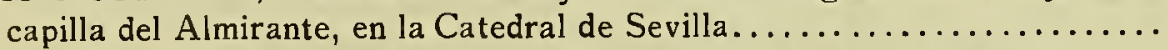
SUÑOL.-Autor, con Blay, de las rejas de Nuestra Señora de París (siglo XIII)...

TOMASINO, Juan.-Rejero agremiado cuya marca era la Bigornia............ TRUJALLON, Guillén.-Rejas de bronce para las capillas de San Bernardo y San

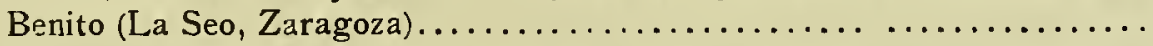

UDOBRO, Diego de.-Autor de la reja (segunda) lateral del presbiterio de la Cate-

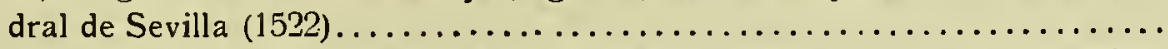

USON, Maestro.-Trabajó en Sigüenza entre los años 1498 al 1519; a él se deben varias rejas en el claustro de la Catedral $y$ doce candeleros..............

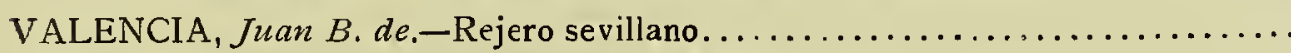

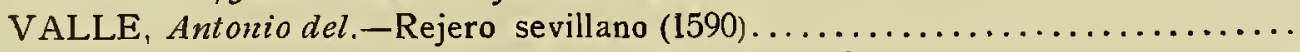

VELEZ, Valentin.-Rejero de Burgos en el siglo XIX .................

VENTURA, Diego.-Cerrajero madr. (siglo XVIIl), inventor de la lima giratoria.

VERGARA, Nicolás, Los.-Ejecutó la verja del sepulcro del Cardenal Cisneros,

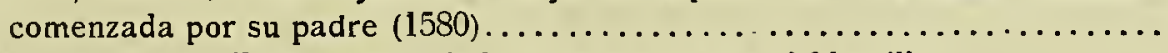

VISERA, Pedro de.-Rejero agremiado cuya marca era el Martillo............

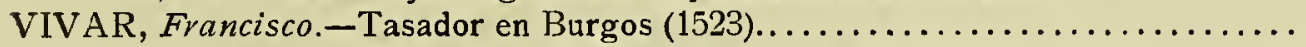

VIVEROS, Antonio.-Rejas de la Catedral de Murcia (1503) ................

VILLALPANDO, Francisco de.-Rejero famoso al que se debe la magnífica reja y púlpitos de la capilla mayor de la Catedral de Toledo (1548)...... 47 y

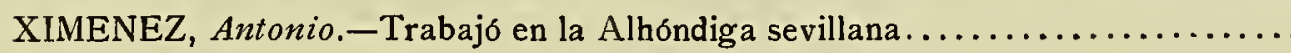

YEPES, Juan.-Trabajó en la reja (primera) lateral de Sevilla (1520)...........

ZAGALA, Juan.-Artillero; concursante para la reja de la capilla real de Granada. ZAMORA, Alonso.--Rejas en la Catedral de Toledo (1647) ................. ZIALCETA, Domingo.- Rejero bascongado, avecindado en Madrid; en 1633 terminó la reja del presbiterio de la Catedral de Sigüenza............... 


\section{Obras consultadas.}

D. Juan Agustín Ceán Bermúdez: Diccionario histórico de los profesores ilustres de Bellas Artes (siglos XV al XVIII).

Señor Condf de la Viñaza: Continuación del Diccionario de Ceán Bermúdez.

Padre Sigüenza: Historia de la Orden de San Jerónimo.

Antonio Ponz: Viaje de España.

D. IsIDORO BosaRTE: Viaje artistico a varios pueblos de España, tomo I.

D. Isidono Rosell: Museo español de Antigüiedades; monografla, tomo II, pág. 349.

D. Josḱ AMADor DE LOS Ríos: Idem, íd., tomo V, pág. 358.

D. Francisco Monsalvatje y Fossas: Gremios de Besalú: Historia de sus Condes y monumentos.

D. Antonio García Llansó: Historia general del arte Metalistería.

Catálogo del Museo Arqueológico episcopal de Vich, 1893.

D. Enrique Repullés y Vahgas: Basilica de San Vicente de Avila, 1894.

D. Luis Tramoyeres Blascu: Instituciones gremiales de Valencia, pág. 46 y siguientes.

D. Manufl Rico Sinobas: Historia y Arte; artículos sobre cuchillería en España. Cincelados en hierro, tomo I, 1895 , pág. 85 y otras.

BaRón DE Algahalí: Diccionario de artistas valencianos, 1897.

D. Manufl Pérez Villamil: La Catedral de Sigüenza, 1899.

IDFM ID.: Discurso de recepción en la Real Academia de la Historia, 12 de Mayo 1907.

René Menard: Histoire artistique du metal, París, 1881.

LaBarTa: Hierros artísticos, Barcelona, dos tomos.

Memoria del Colegio de Maestros Cerrajeros, Armeros y Agujeros de Barcelona, $1 .^{\circ} \mathrm{de}$ Enero de 1905.

D. José Gudrol Y Cunill, presbitero, Director del Museo de Vich: Arqueología Sagrada Catalana.

Album de detalles artisticos de la Edad Media Catalana; impresor, D. Luis Tasso, Barcelona.

D. Pablo Alzola: El Arte Industrial en España.

Cortezo y Compañía, editores: España y sus Monumentos (Salamanca, Avila, Segovia, Valladolid, Palencia, Toledo y Sevilla).

Baron Ch. Davillier: L'orfevrerie en Espagne.

PIERRE PARIS: Enssai sur l'art et industrie de l'Espagne primitive, tomo II.

D. Josí Gestoso PÉrez: Sevilla Monumental y Artistica, 1890.

IDEM ID.: Ensayo de un diccionario de los artifices que florecieron en esta ciudad de Sevilla desde el siglo XIII hasta el XVIII, «Rejeros», tomo II, pág. 362, 1900

D. NaRciso Sentenach: Bosquejo histórico sobre la orfebreria española, 1909.

D. José Marti Monsó: Estudios histórico-artisticos, relativos principalmente a Valladolid, y otros que van anotados en el textó. 
Indice analitico de materias.

Páginas.

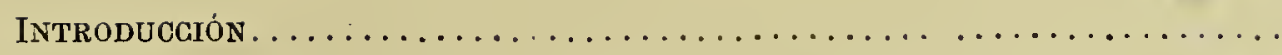

HISTORIA.-EPOCA PRIMERA.-Origenes del hierro.-Edad del hierro en España.-La forja catalana.-Ejemplares primitivos. - Idem romanos.Idem visigodos.-Periodo árabe.-El damasquinado.............

EPoca SEgunda.-Periodo románico-ojival.--Rejería románica.-Ejemplares.-Siglo XIII.-Rejeria ojival.—Gremios.-Siglo XIV -Primeros autores.-Ejemplares._Siglo XV._Ejemplares y autores..........

Período de transición. - Autores y ejemplares....................

Epoca terCera.-Renacimiento.-Rejas platerescas.-En la Catedral de Sevilla.-Sus autores. - Otros rejeros sevillanos. - Rejas en Granada.Sus autores.-Rejas en Toledo.-Sus autores.-Verja del sepulcro del Cardenal Cisneros. - Cristóbal Andino. - Sus o’oras. - Otros rejeros españoles del siglo XVI. - Otros objetos de hierro en este siglo. Verjas del sepulcro del Obispo Anaya y de San Juan de Ortega.- Mlue.

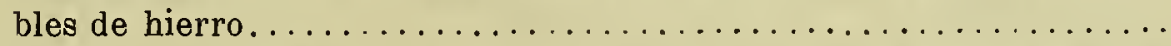

Epoca CUaRTa,-Siglo XVII.-Autores y ejemplares.-Otros objetos de hie-

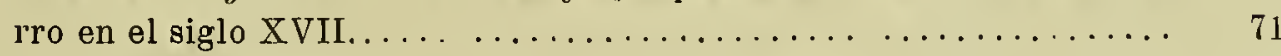

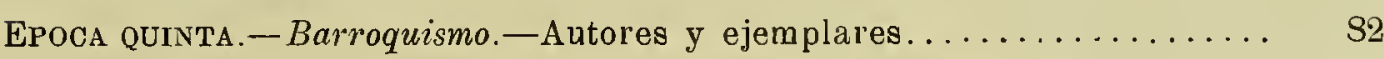

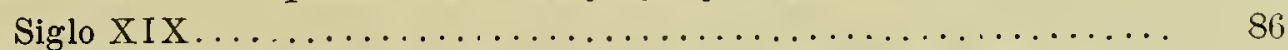

Indice cronológico de las obras más notables citadas en este estudio, con

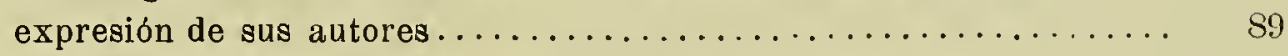

Indice alfabético de los artistas rejeros citados en esta obra.......... 91

BIBLIOGRAFIA. -Obras consultadas......................... 96 

$\because$ LAMINAS 



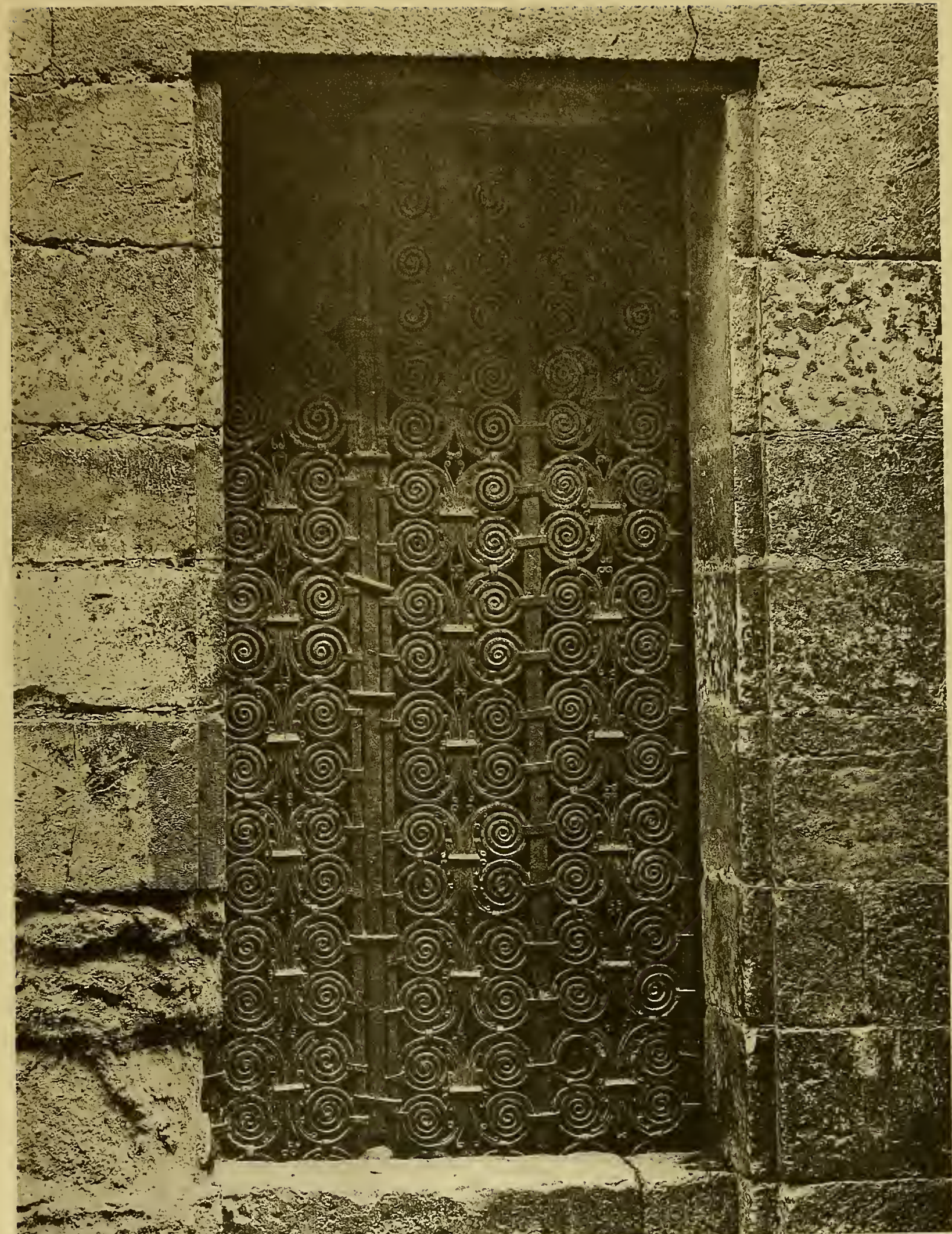

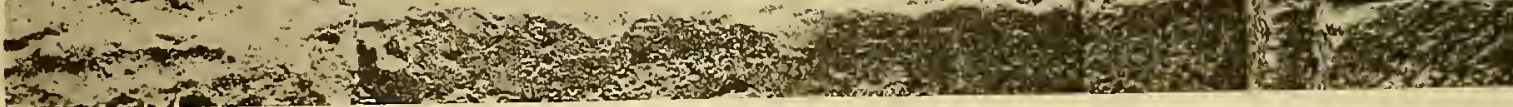
Fot. Lacoste 

30

(6)(0)(0) (0) อ. Q) (C) (0) (0) (O) (e)(0) (0) (9)

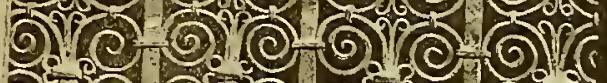

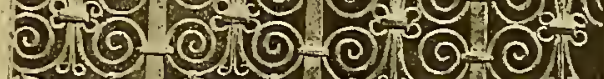

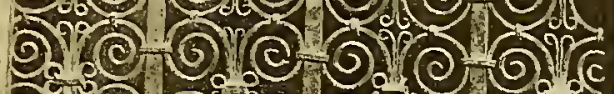
(2)

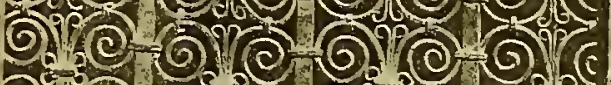
C)(0) (0) (9) Q) (0) D. (0) (0) (2) (0) ? (c) 0.1(c) (c) (c) (9)

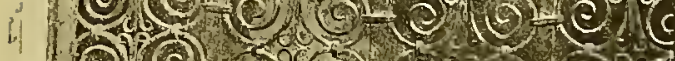
(5) (0) 01 (5) (0) (6) c.00(0) (2)

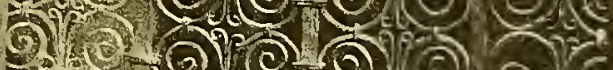
อ1(ง) - MLe (a) (0)

2010) (6) (c) 6 ) - rim b) (a) (9) (2) - 5. UC (C) (C)

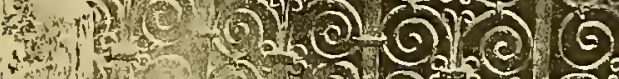

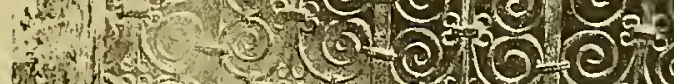

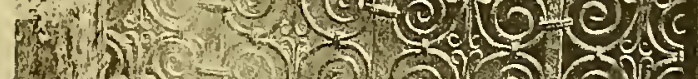

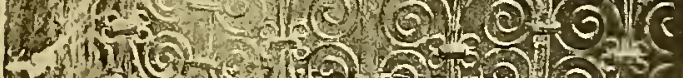
H

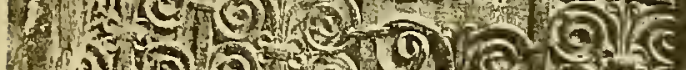
a) $(0,0)$ (a) (a) (a) (a) D) จ.

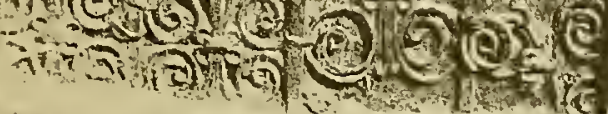
41
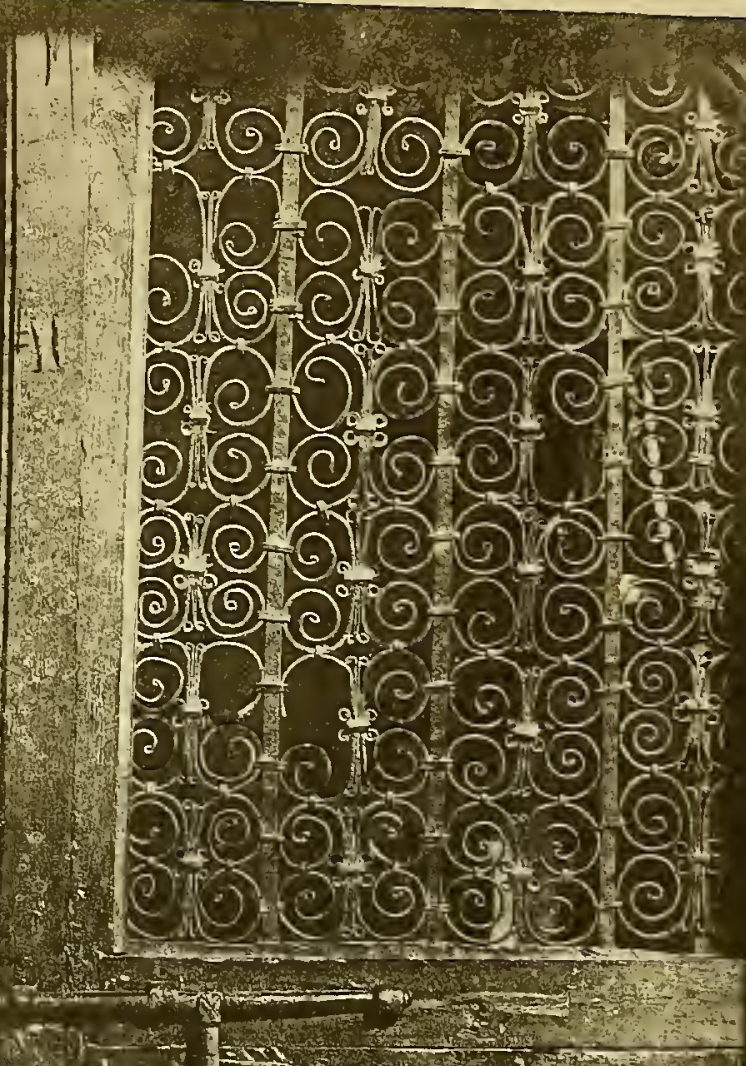

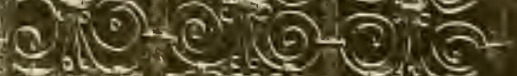
9) 1000 ? 3)(a) (a) (2) 9 ल 5) $(2), 8)$ (a) Q A 3 का 


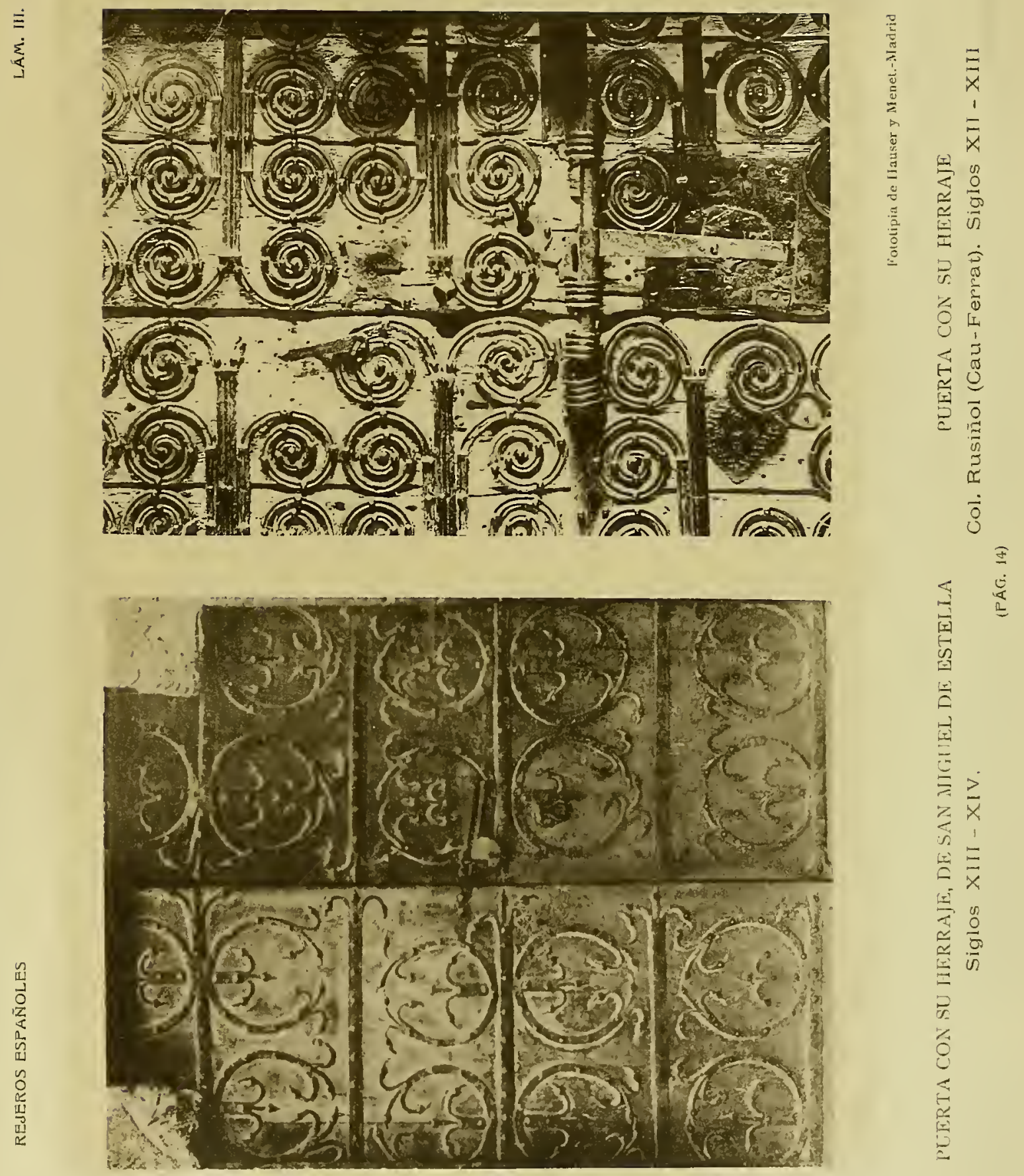



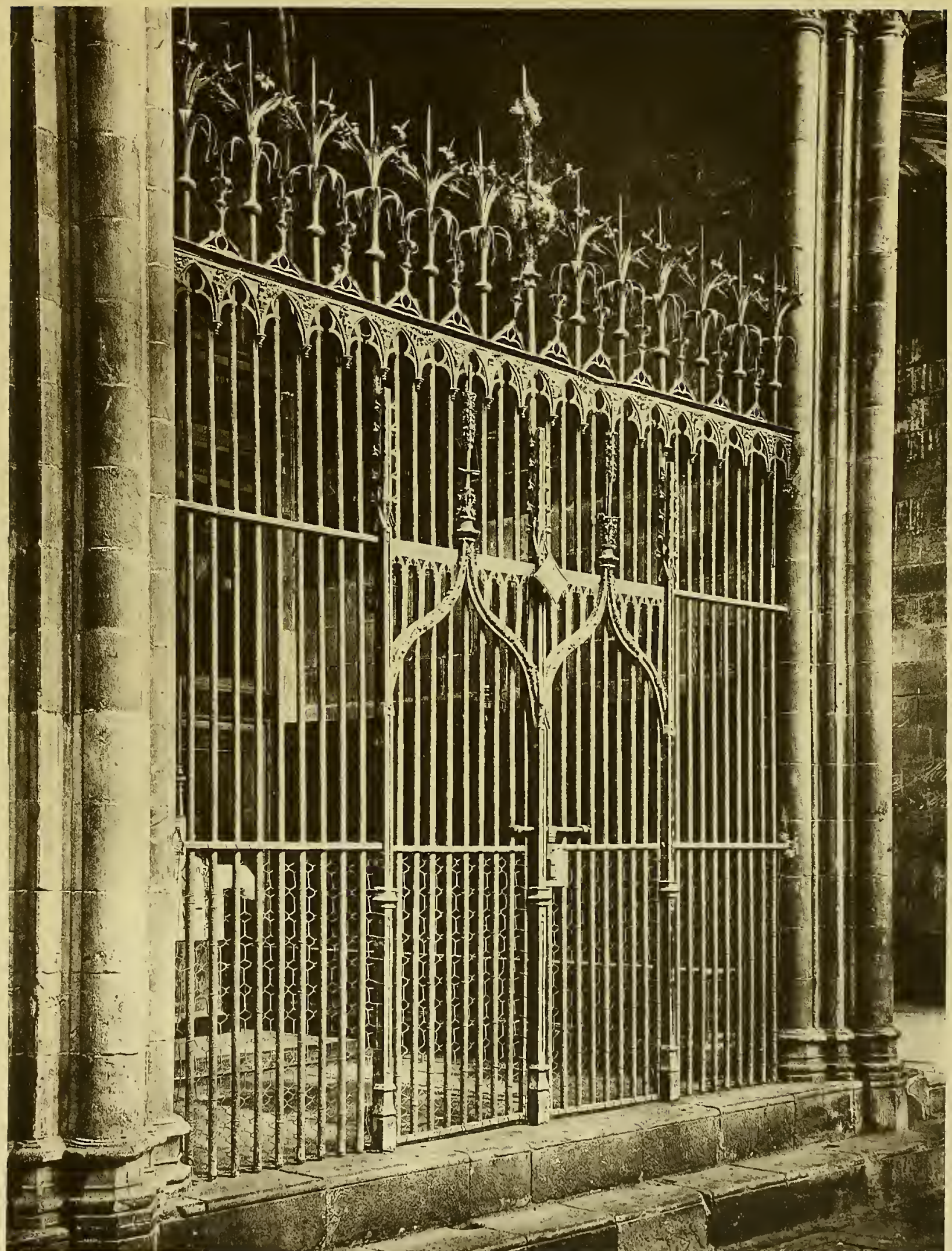

REJA DE UNA CAPILLA EN EL CLAUSTRO DE LA CATEDRAL DE BARCEIONA 


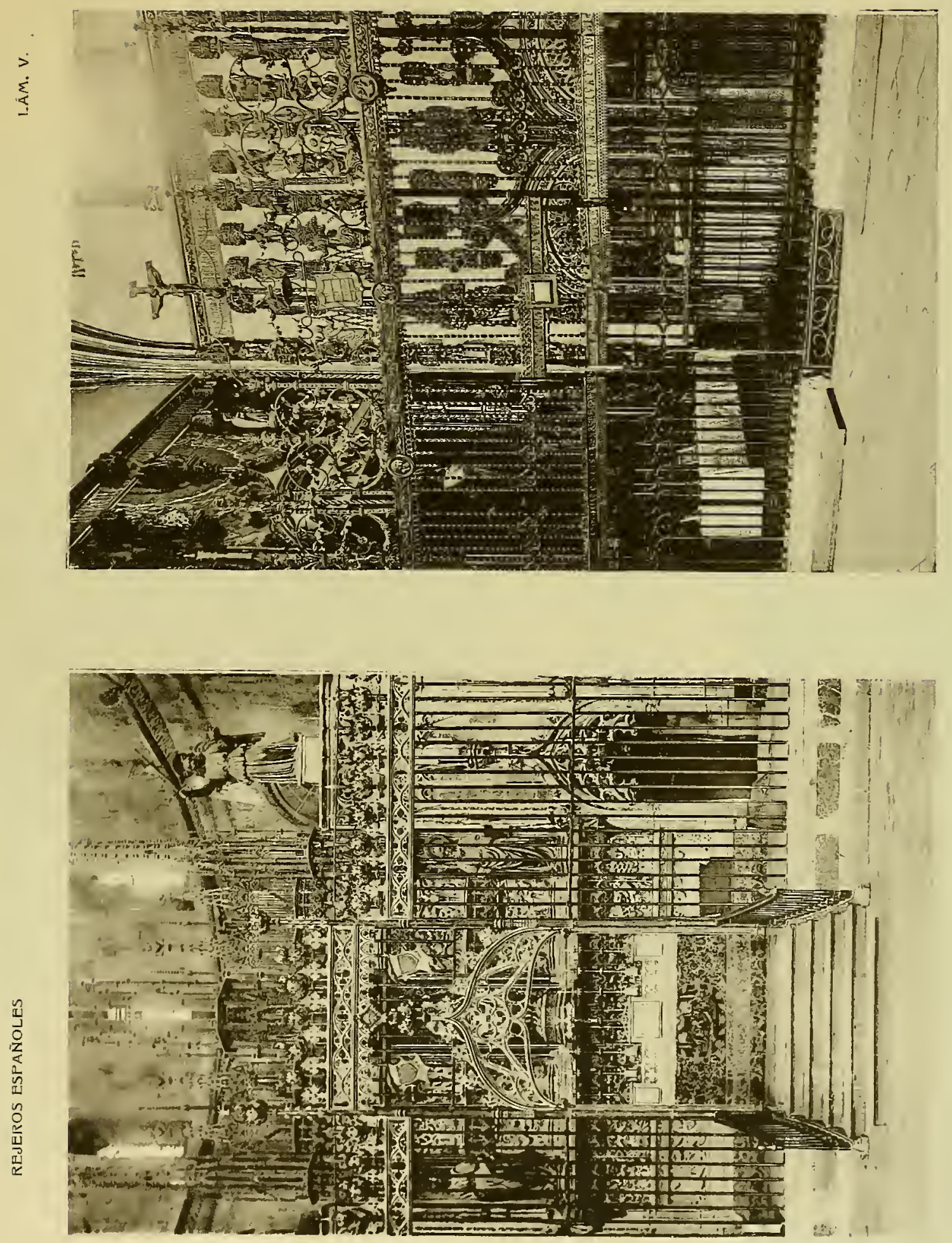

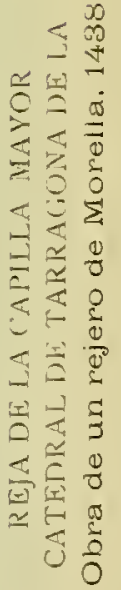





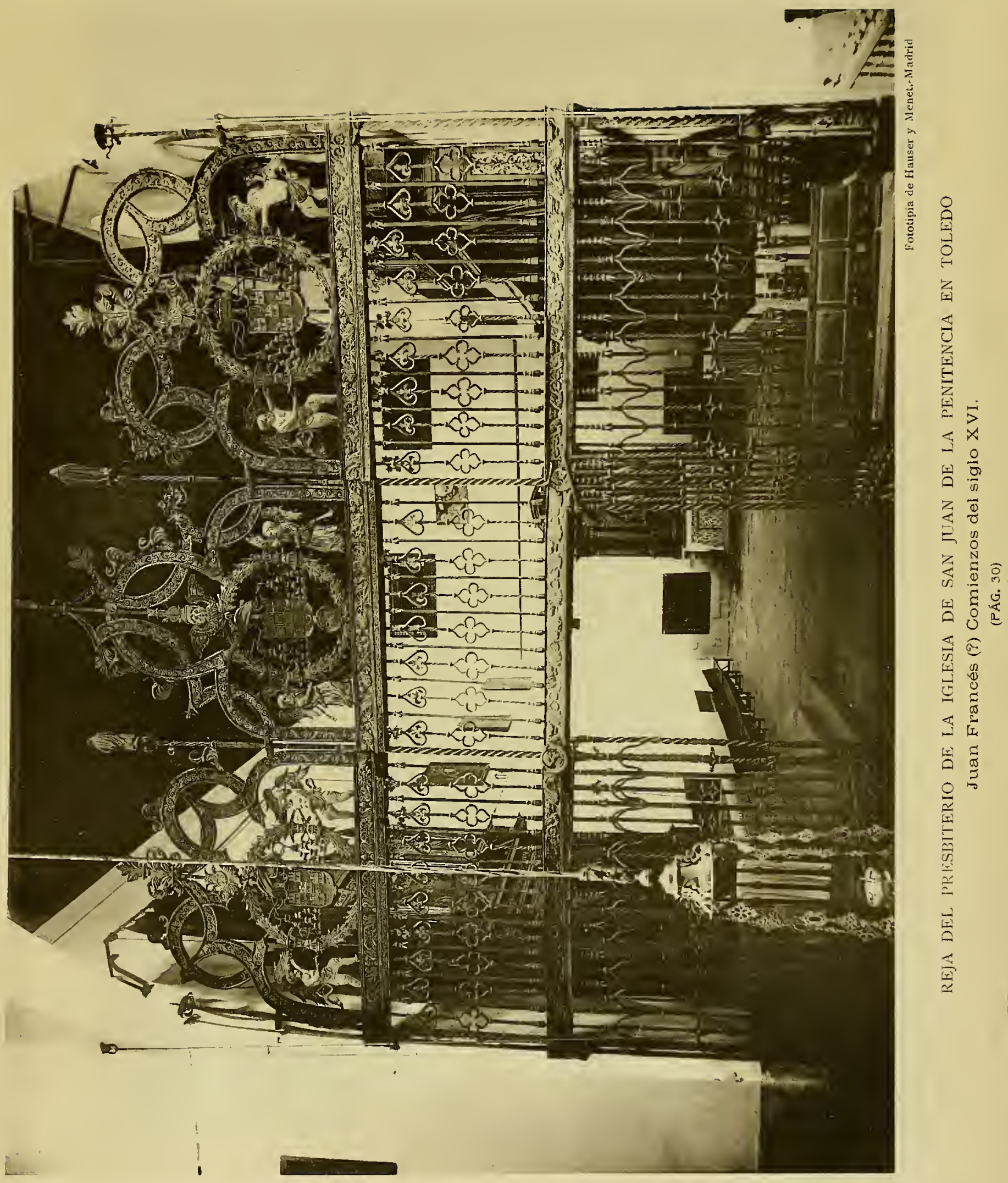





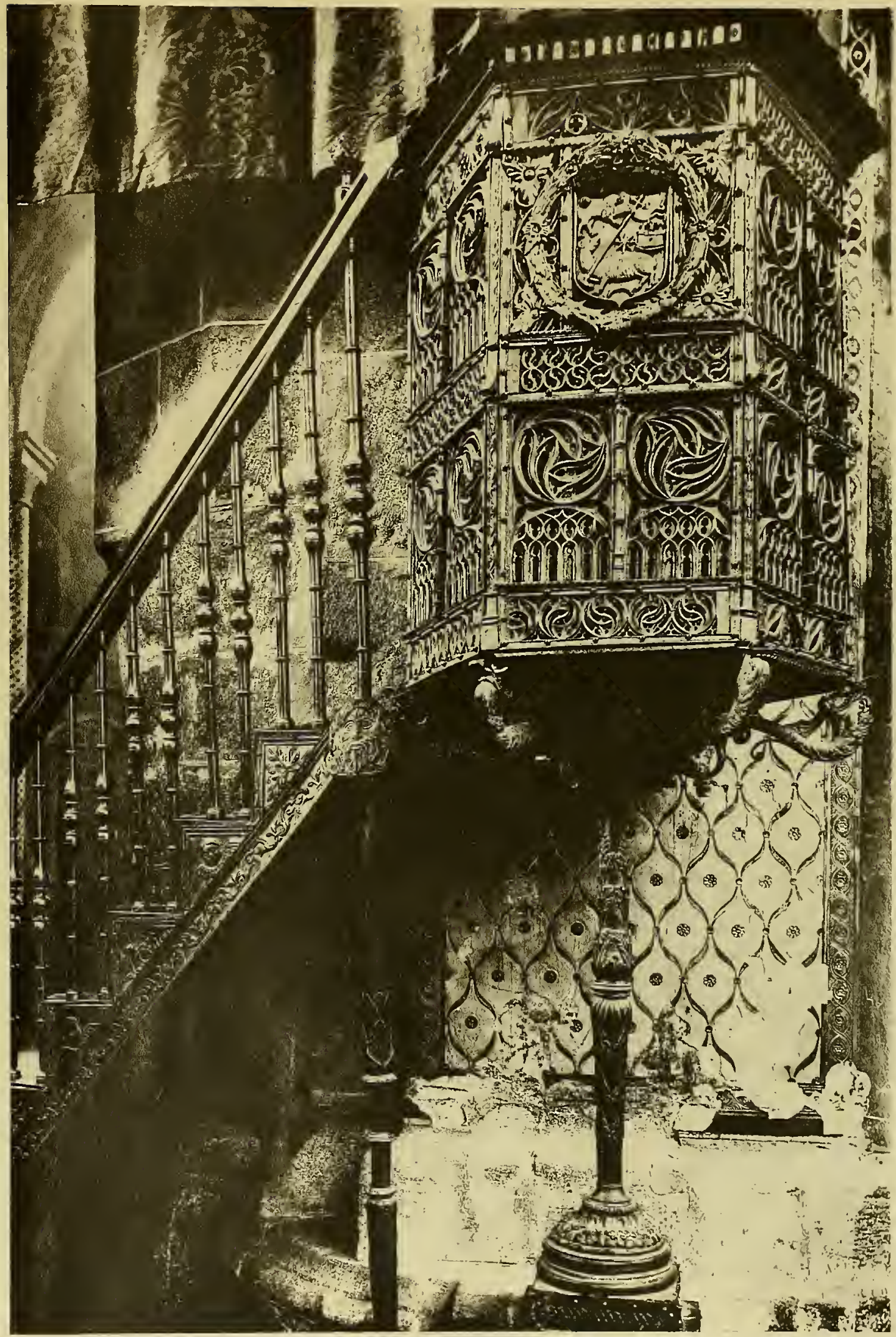





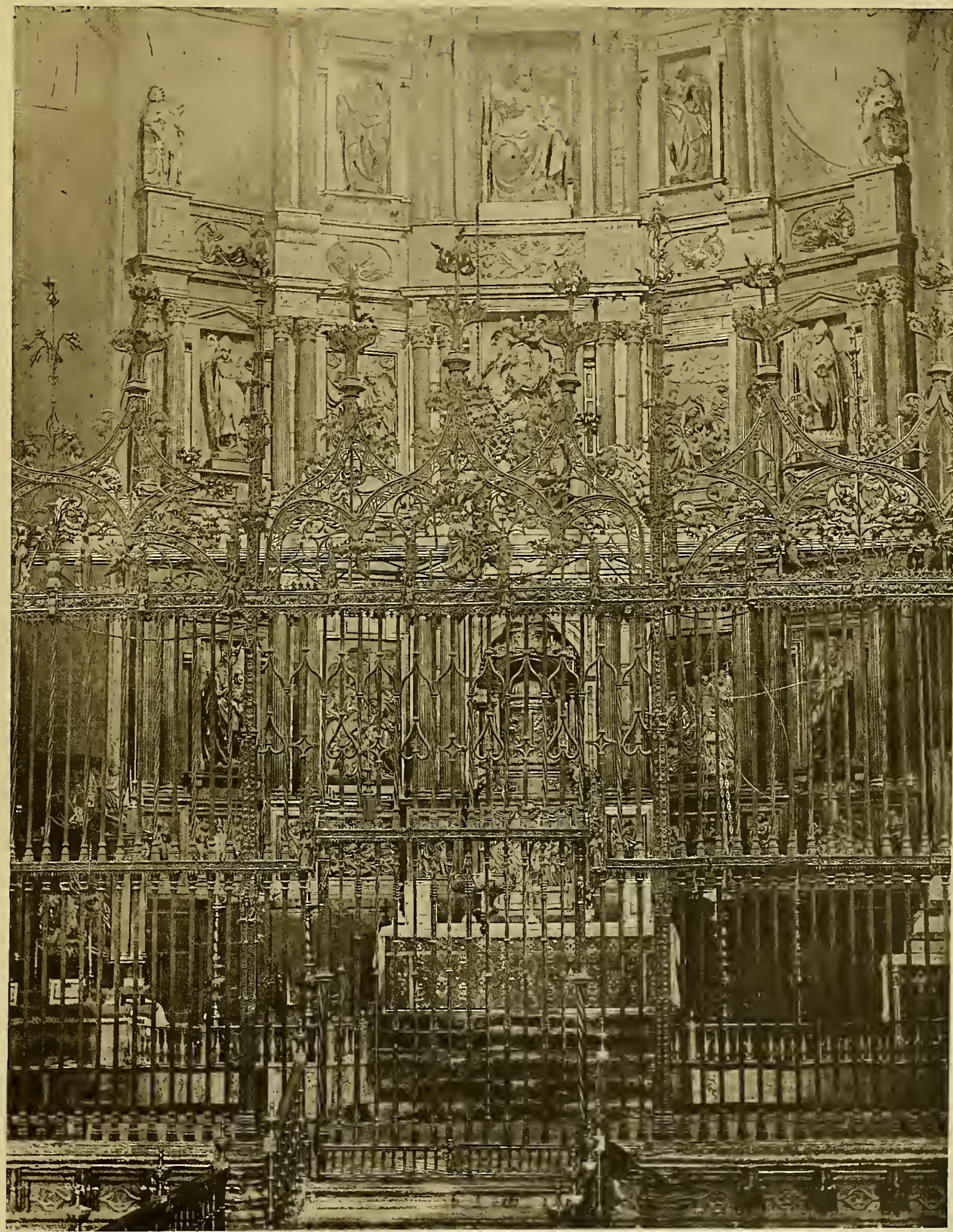

Fot, Roldan

REJA DE LA CAPILLA MAYOR DE LA CATEDRAL DE PAMPLONA Obra de Guillermo Ervenat 1517 



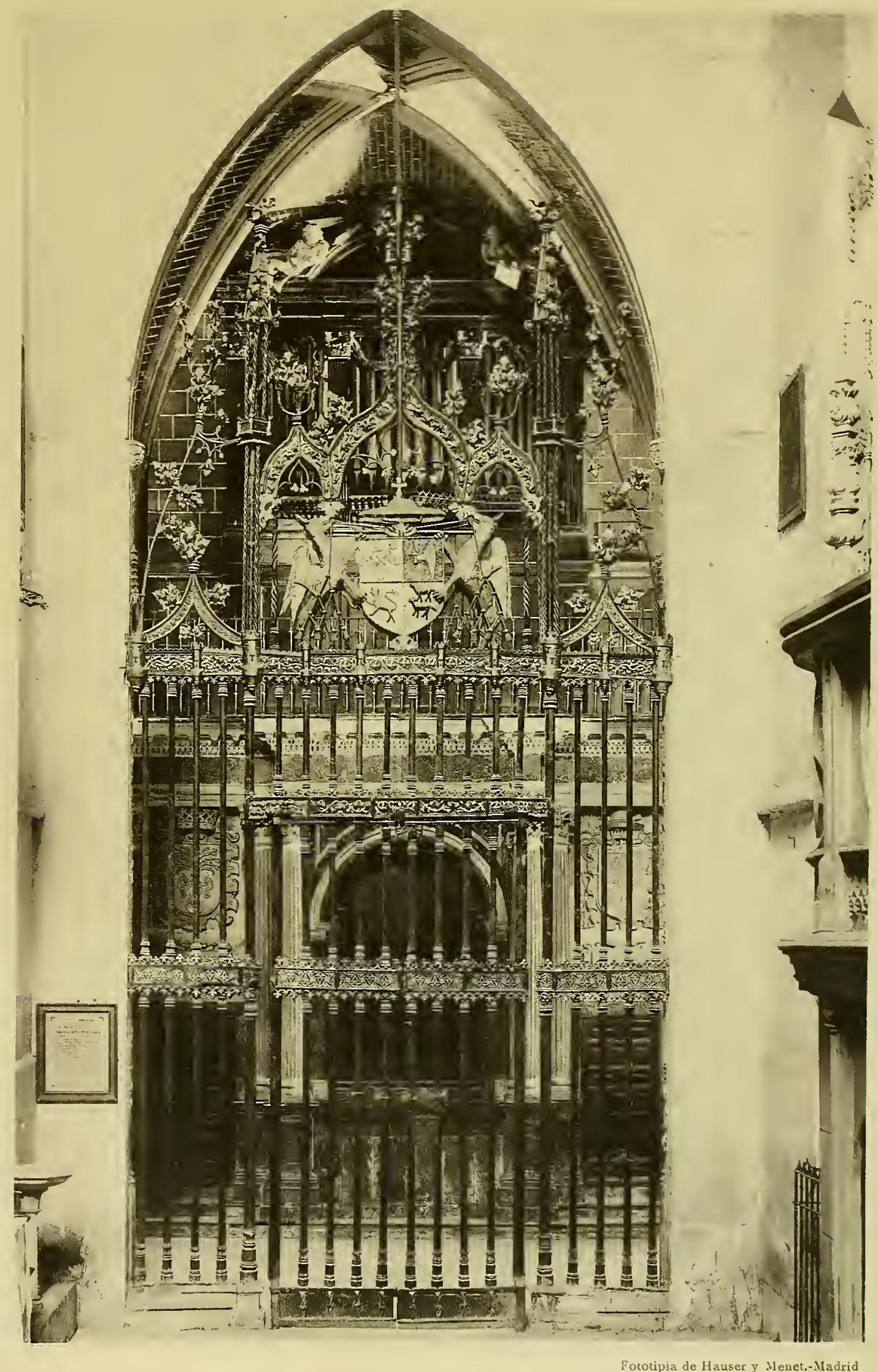

REJA DE LA CAPILLA DE SANTA ANA EN LA CATEDRAL DE BURGOS

Ostenta el escudo de D. Luis de Acuña, obispo de aquella diócesis, fundador de la Capilla. Obra de autor desconocido. Siglo XV. 



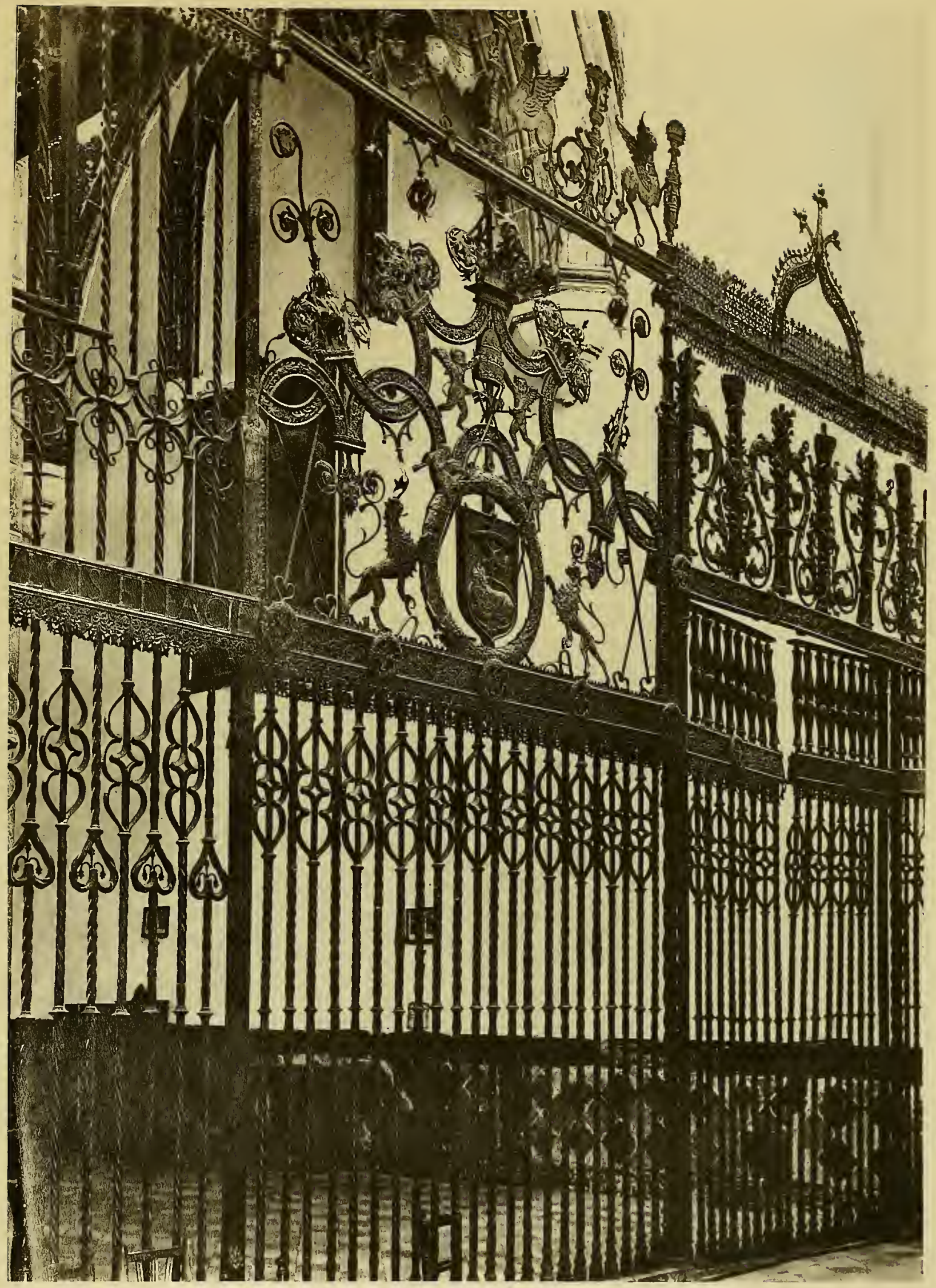





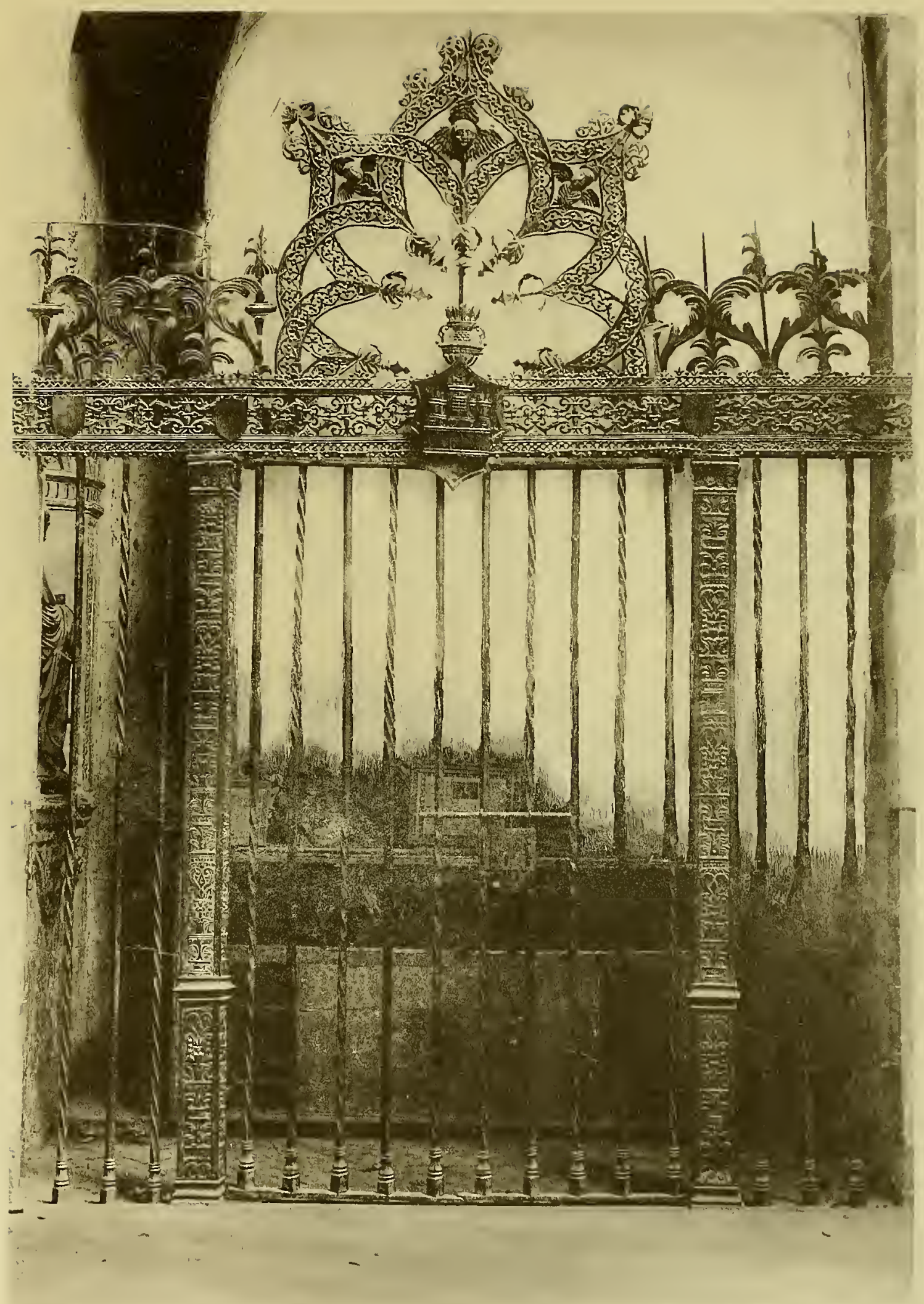

Fototipia de Hauser y Mesel.-Madrid

RETA DE LA CAPILLA DE SANTA ANA EN LA CATEDRAL DE HUESCA Obra de Amau Guillen, terminada en 1525 


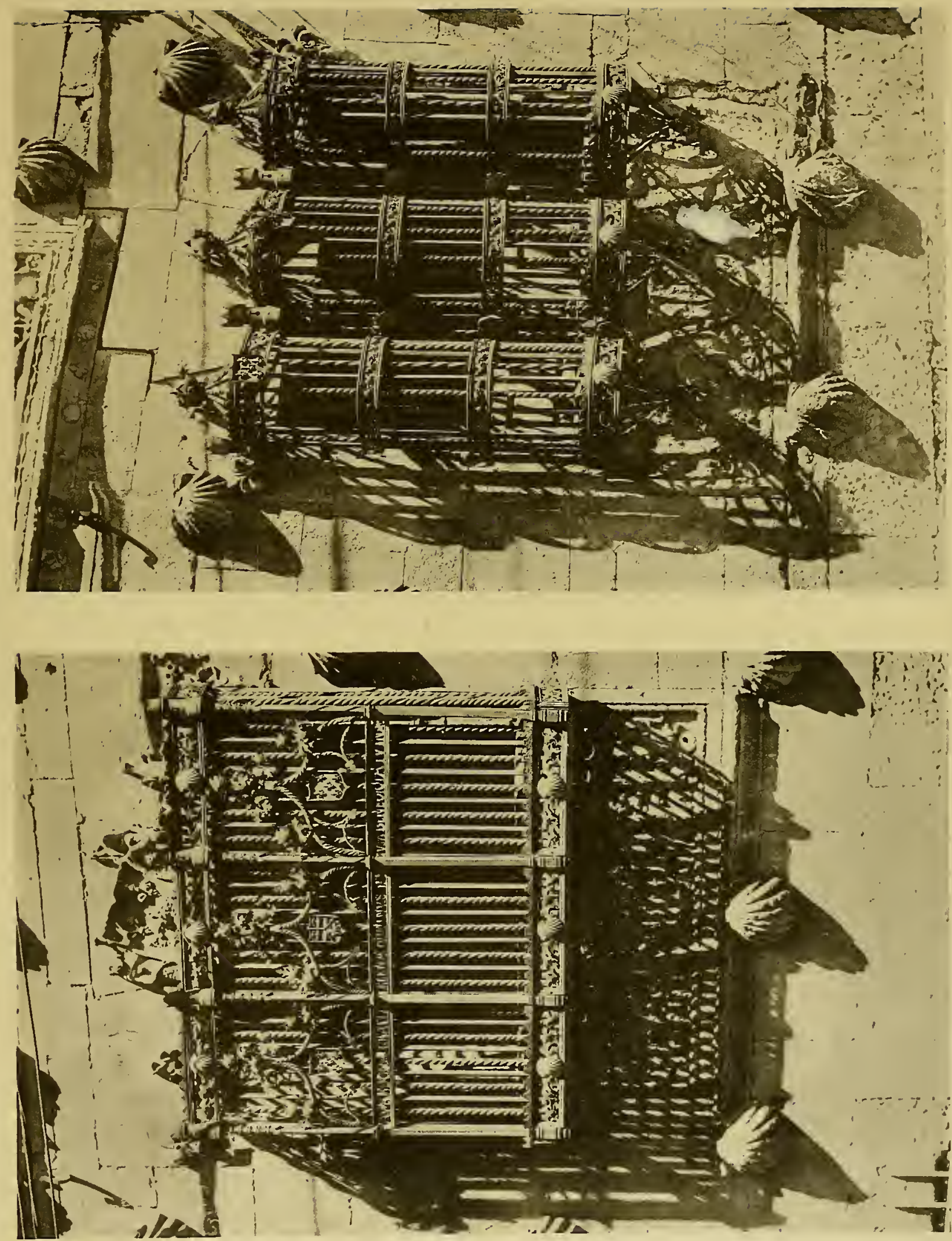



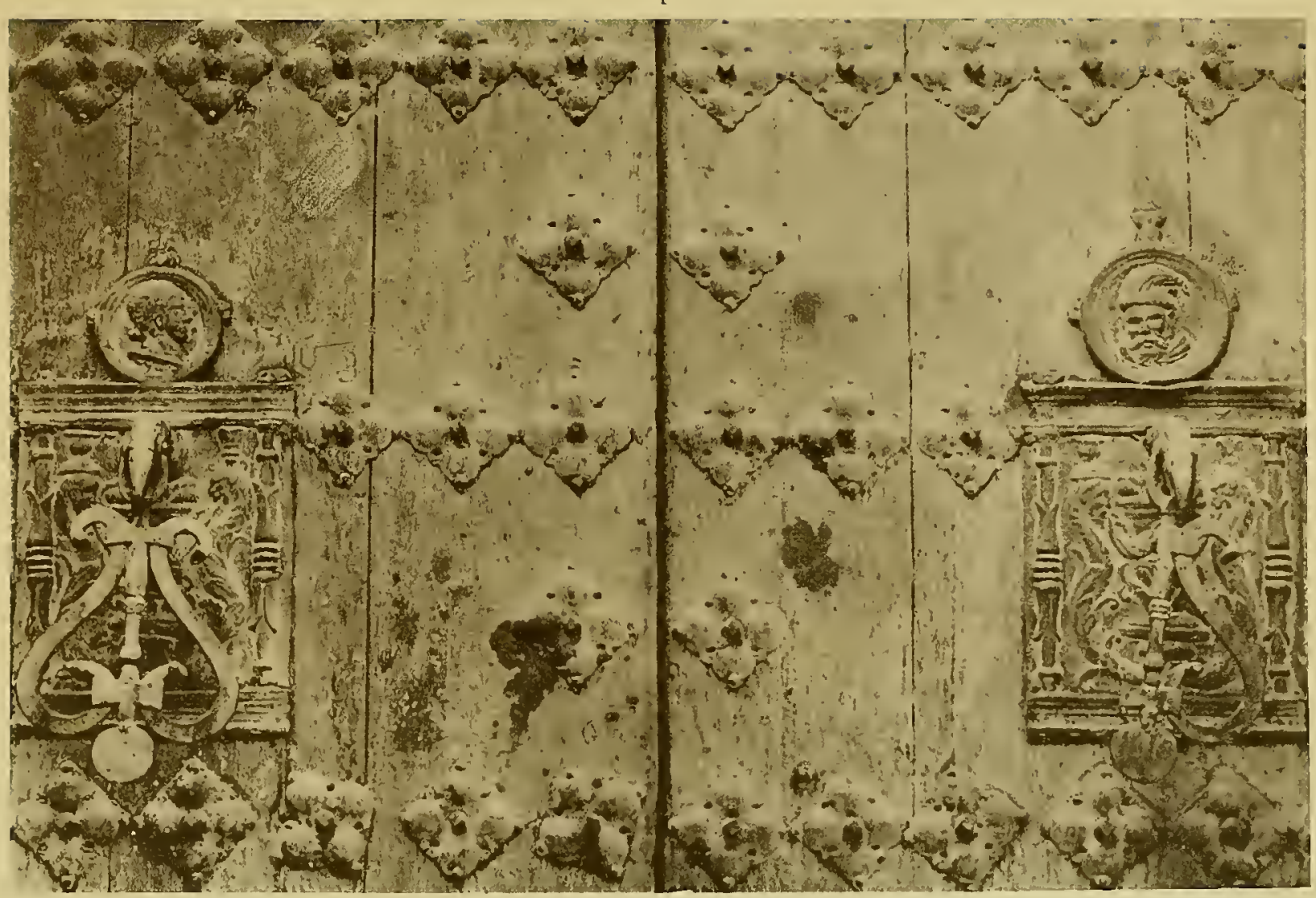

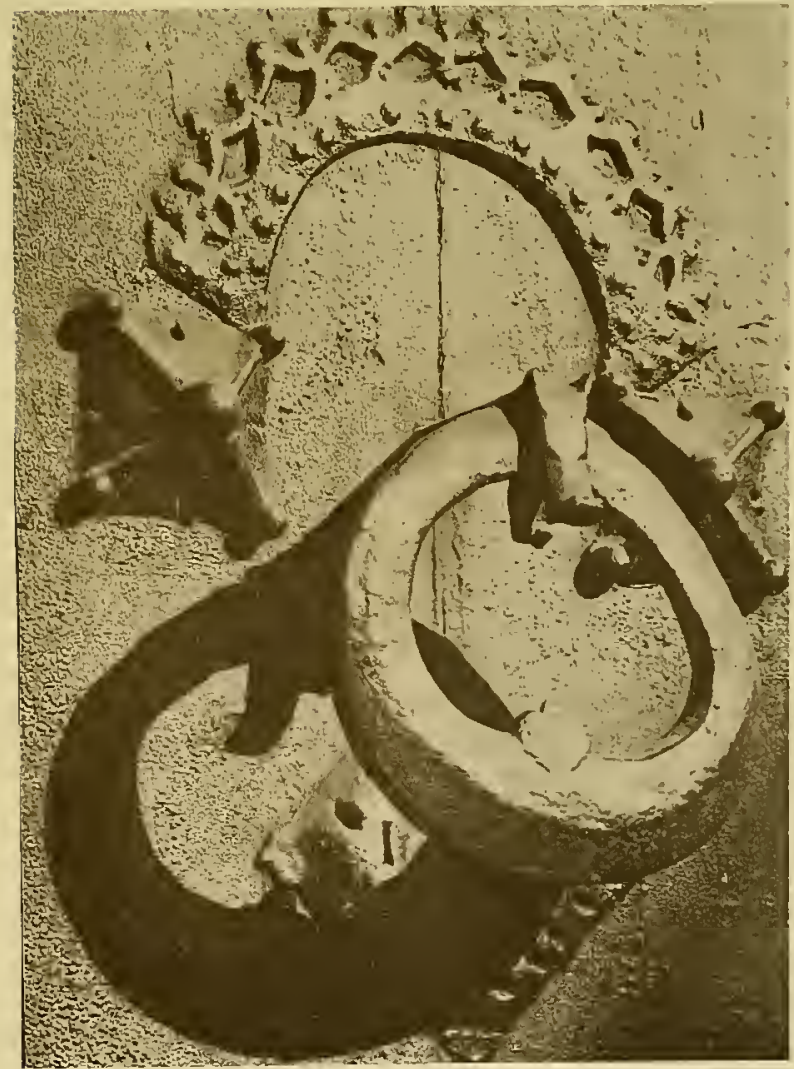

3

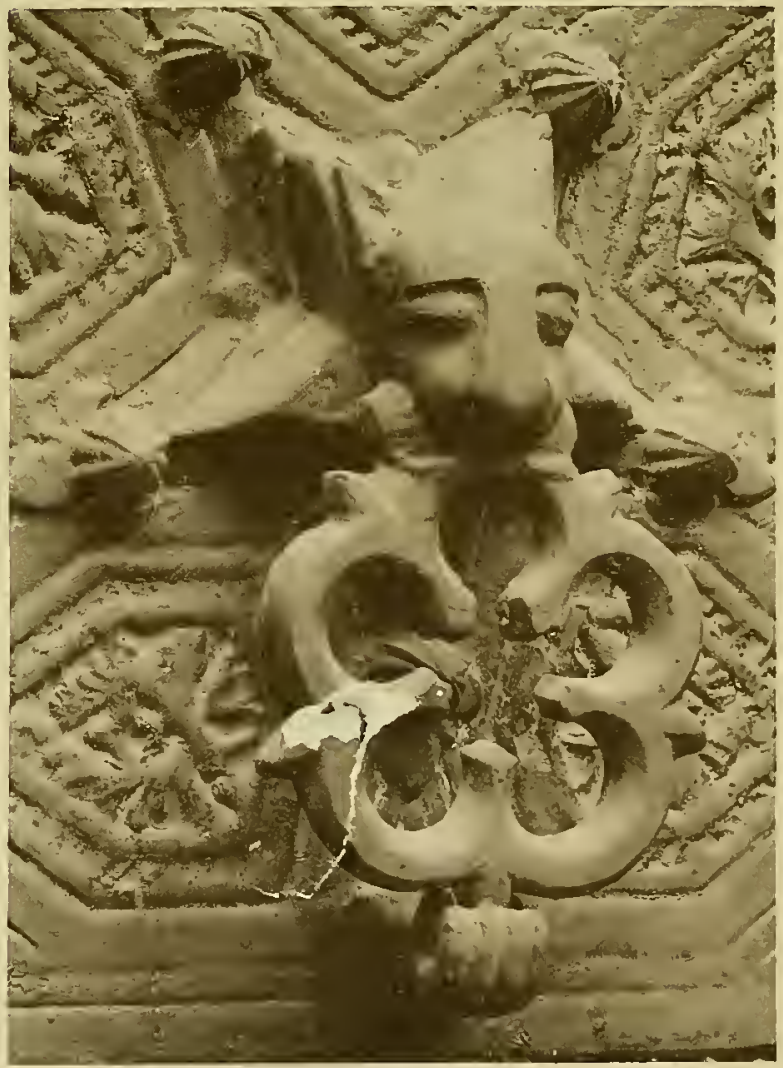

Folotipia de Hauser y Menet.-Madrid

ALDABONES DE LA REGION ANDALUZA

1.-Puerta con sus herrajes, de una casa particular.

2.-Aldabón de la puerta de

3.- Aldabón de la puerta nuudéjar de la Catedral de Sevilla.

(PÅG. 32) 


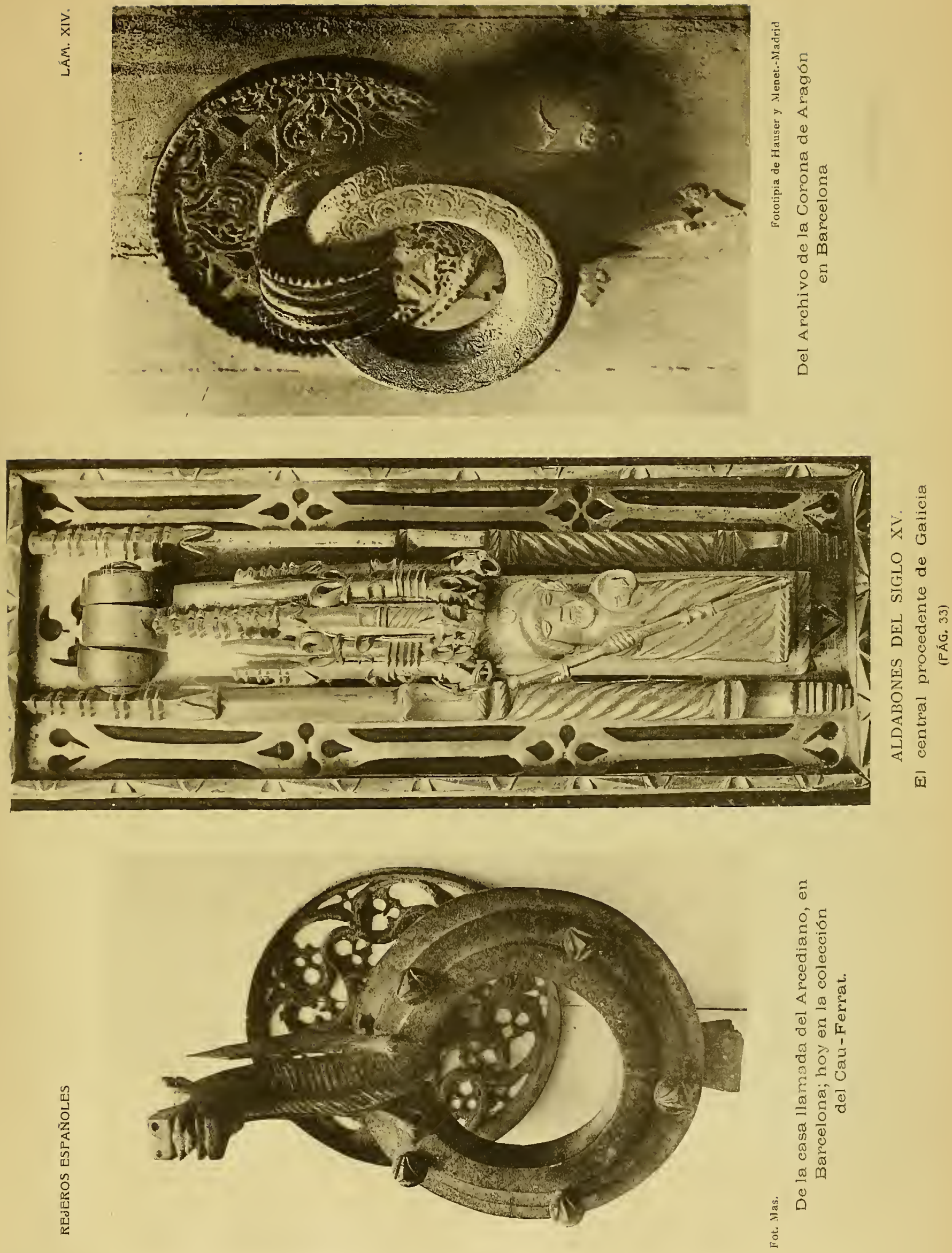



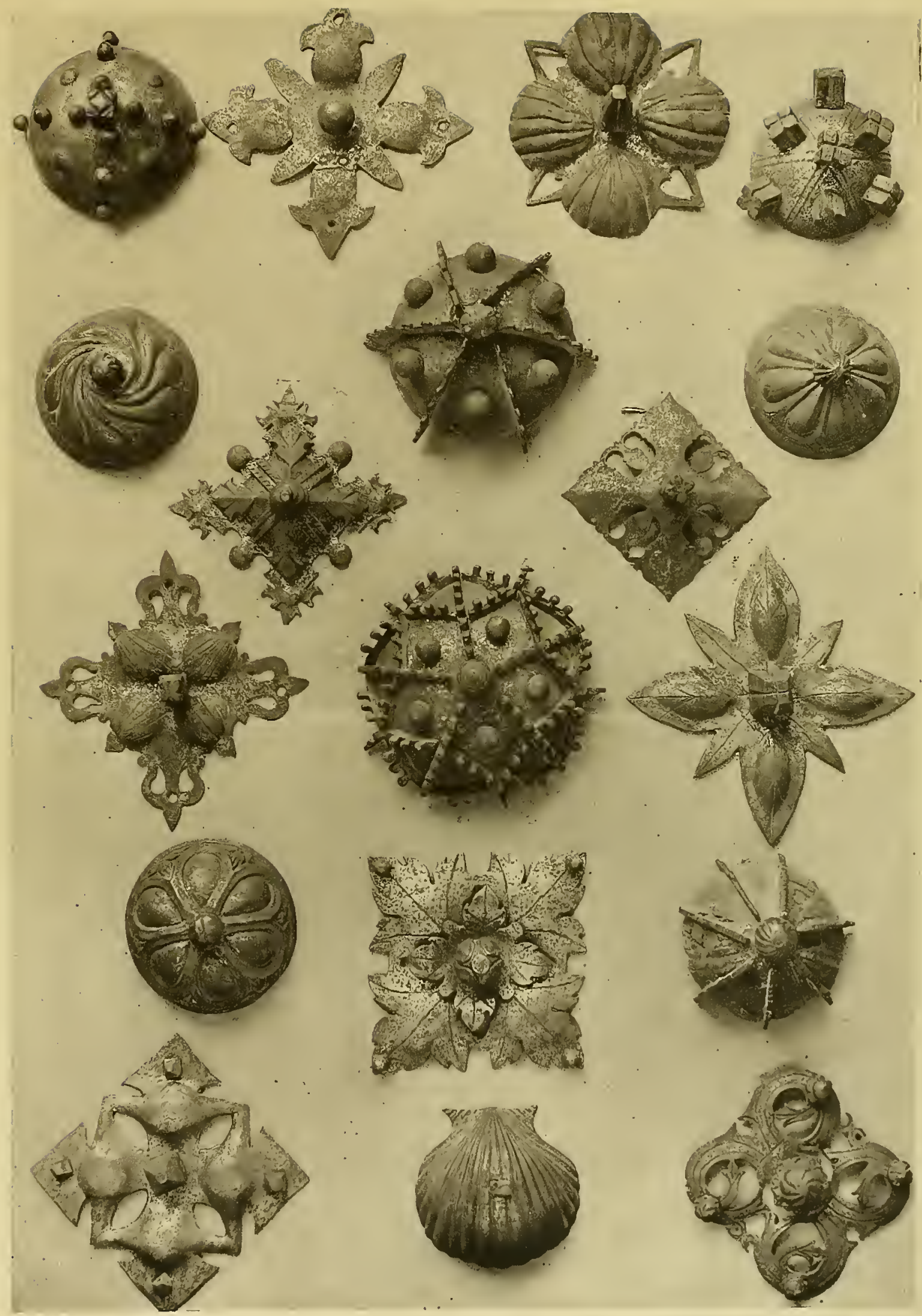

Fototipia de Hauser y Mlenet,-Madrid

CLAVOS DE HIERRO DE LA COLECCIÓN DEL EXCMO. SR. D. ADOLFO HERRERA (PÁGS. 33 Y 69) 



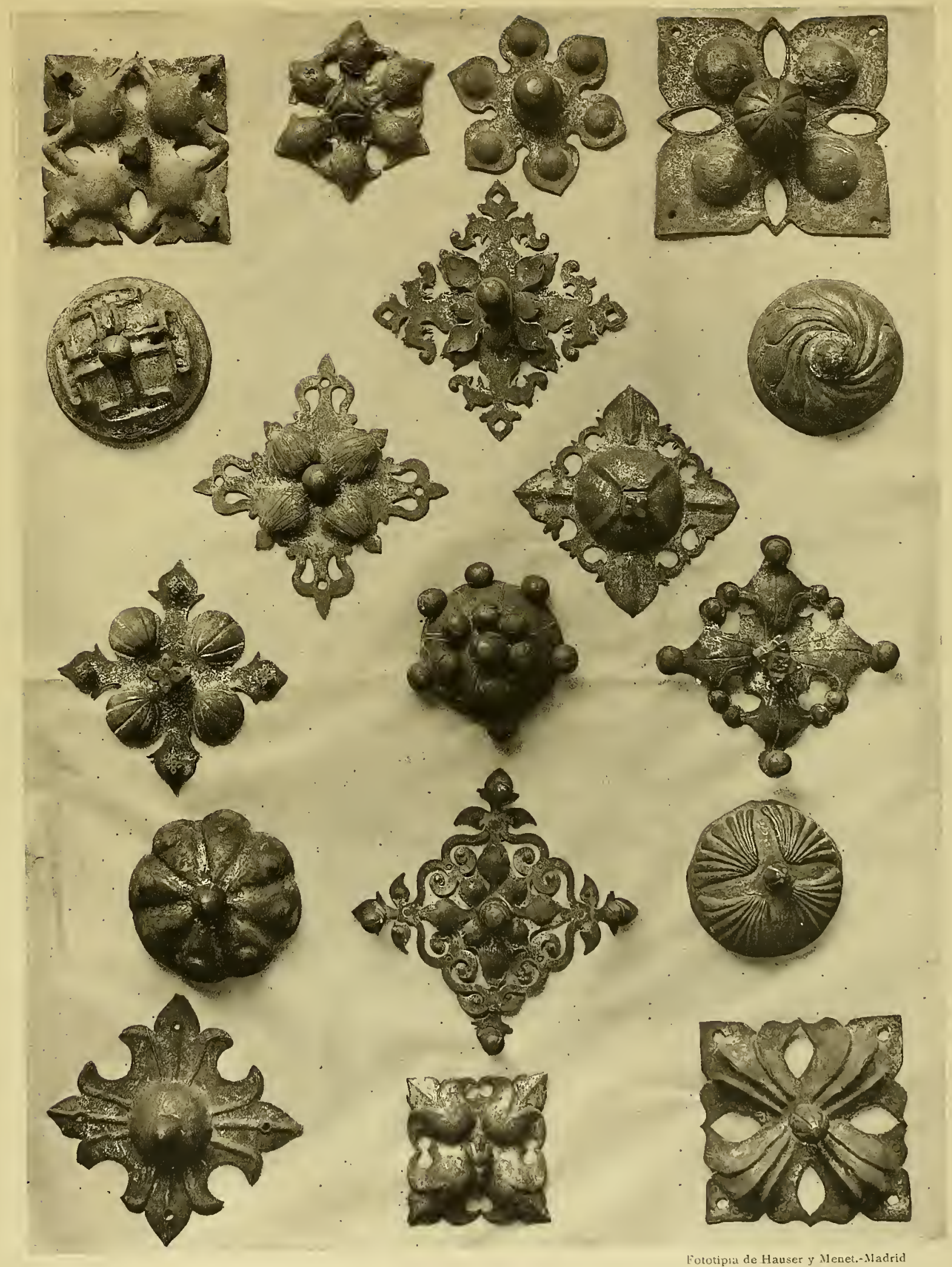

CLAVOS DE HIERRO DE LA COLECCIÓN DEL EXCMO. SR. D. ADOLFO HERRERA (PÁGS. 33 Y 69) 

$\xi$
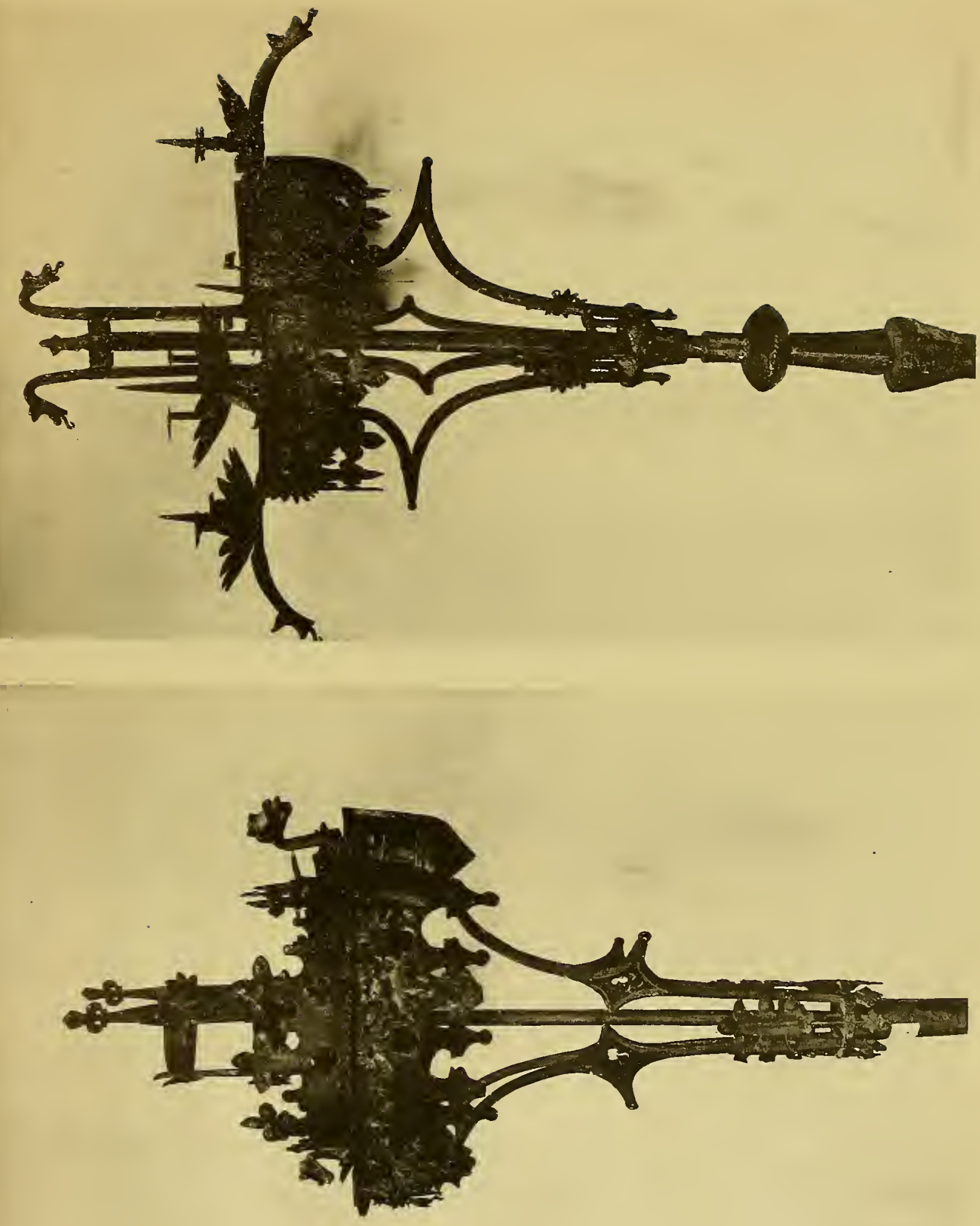

垈 


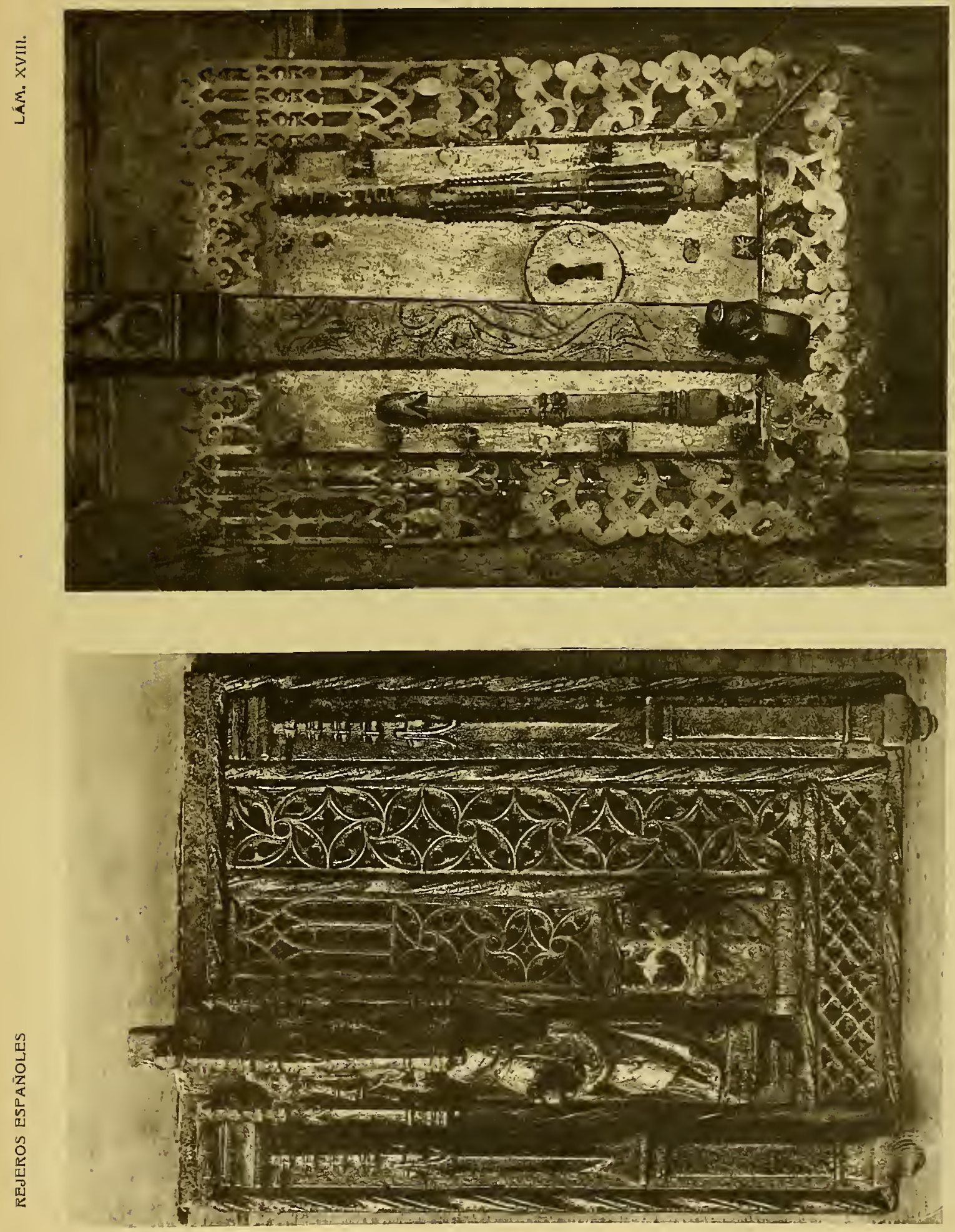



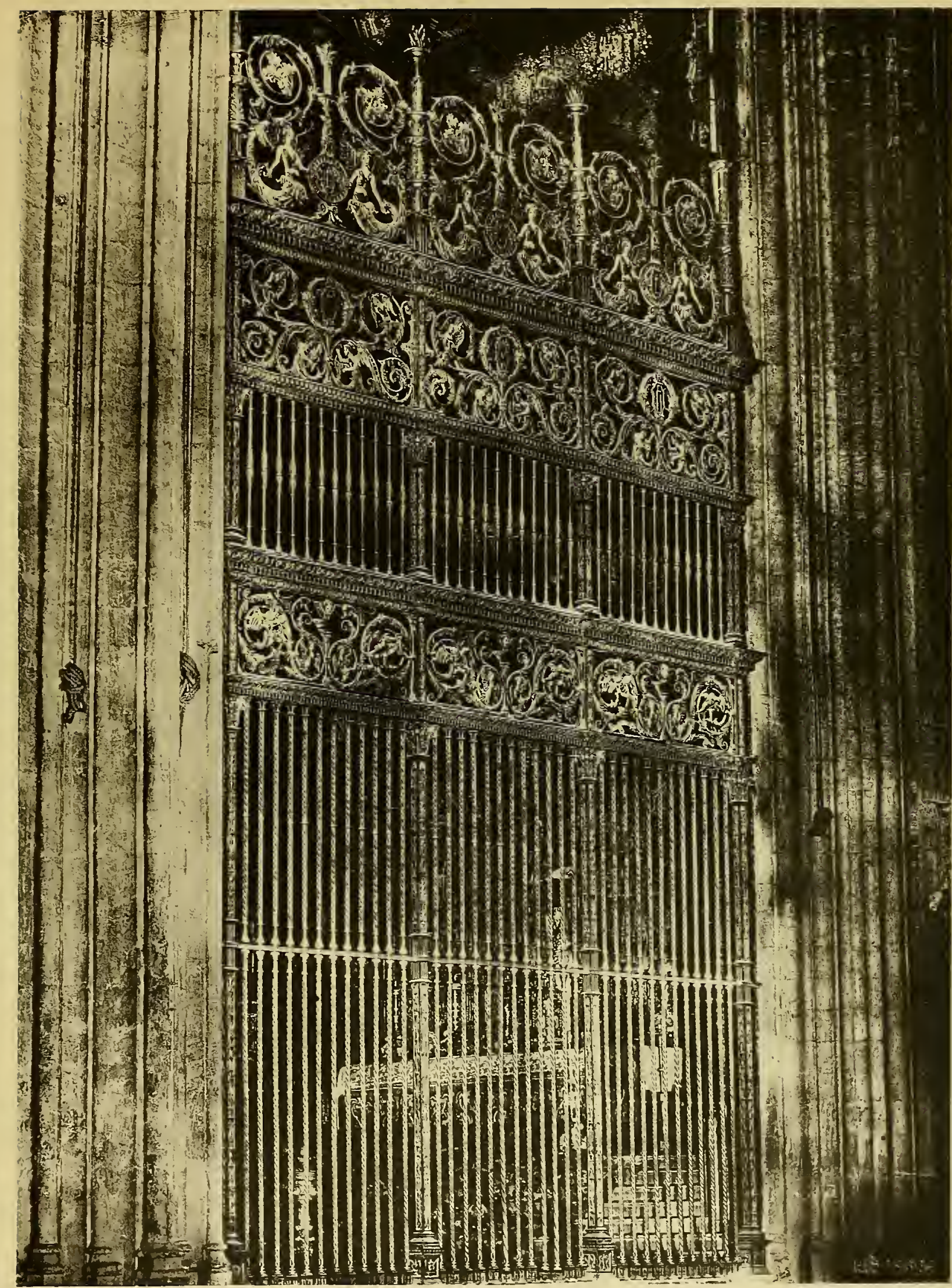

Fot, Lacoste

REIA LATERAL DEL LADO DE LA EPÍSTOLA, PRESBITERIO DE LA CATEDRAL DE SEVILLA 

REJEROS ESPAÑOLES

LÁN. XX.

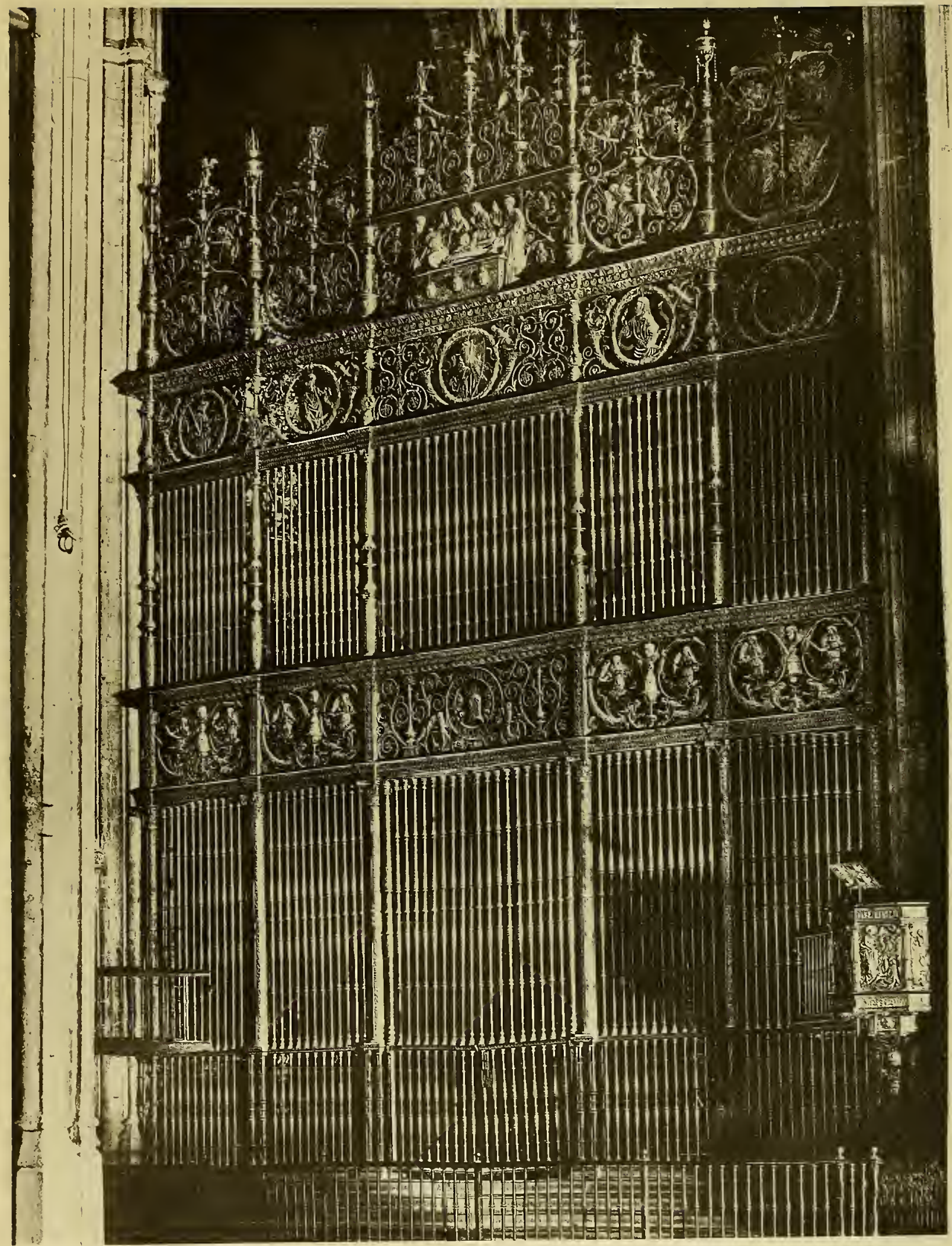

REJA DEL FRENTE DEL PRESBITERIO DE LA CATEDRAL DE SEVILLA Obra de Fr. Francisco de Salamanca, terminada en 1529 



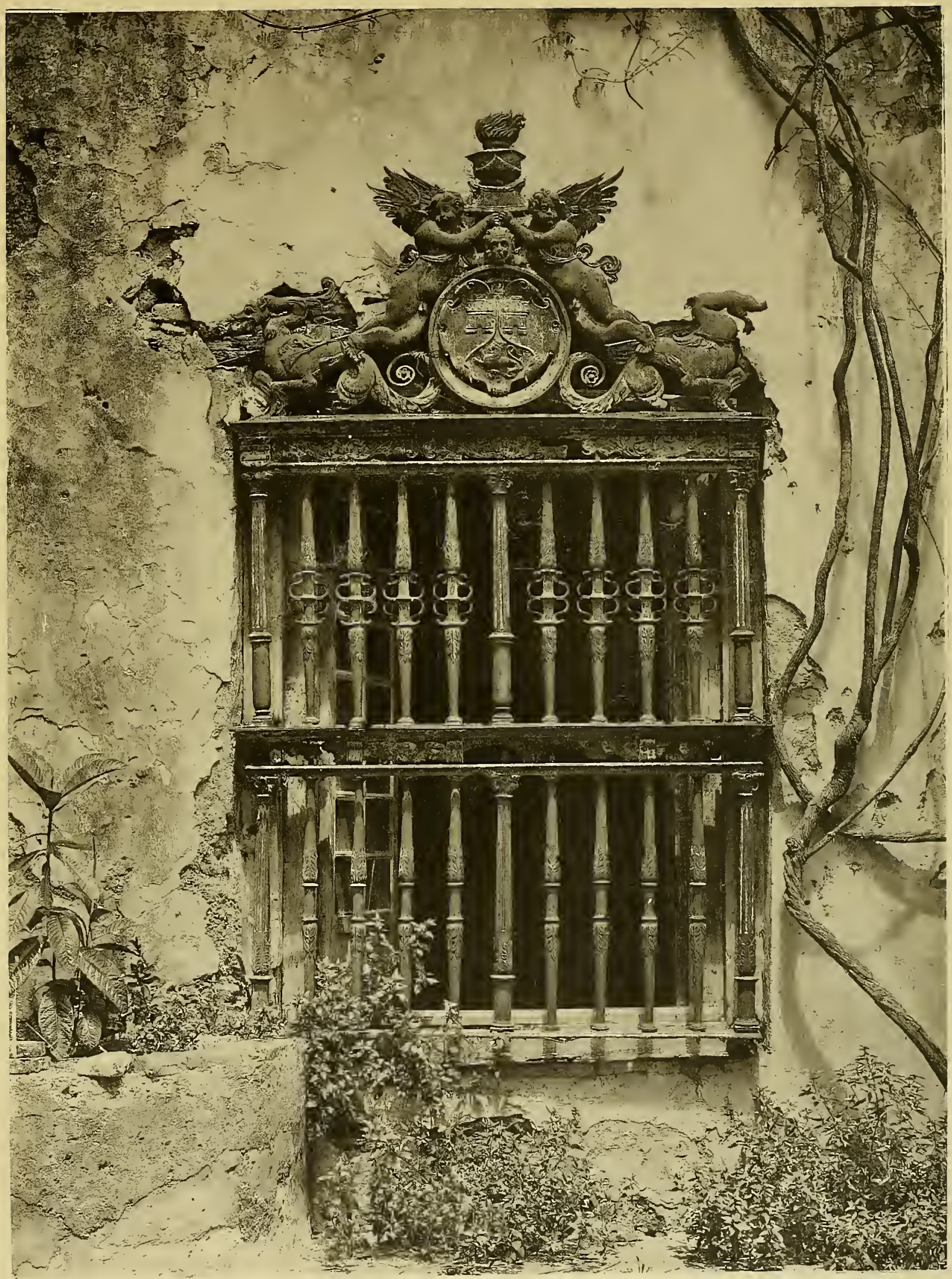

Fototipia de Hauser y Menct.-Madrid

REJA DE LA CASA LLAMADA DE PILATOS

Palacio de los Duques de Alcalá. Sevilla. Siglo XVI. 



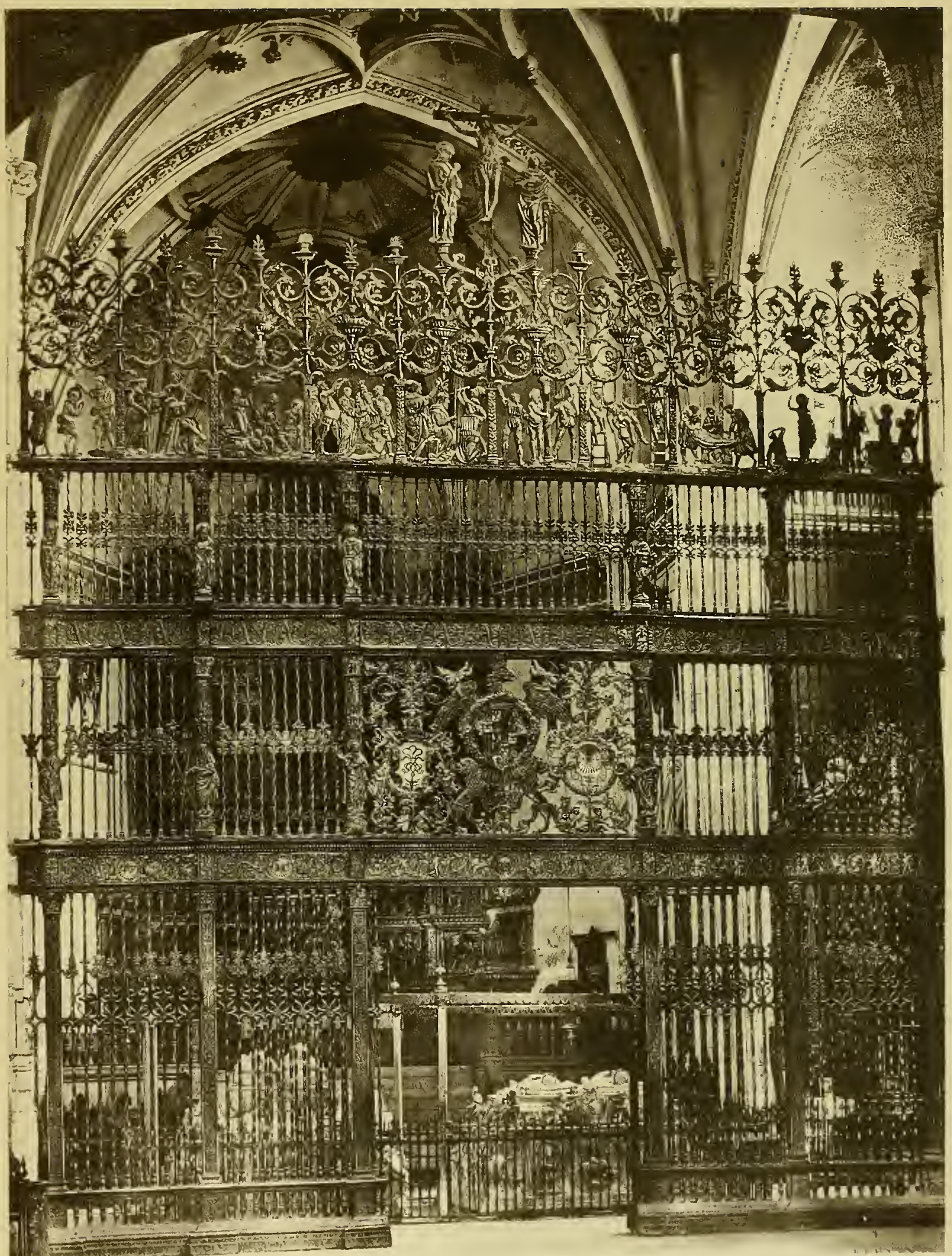





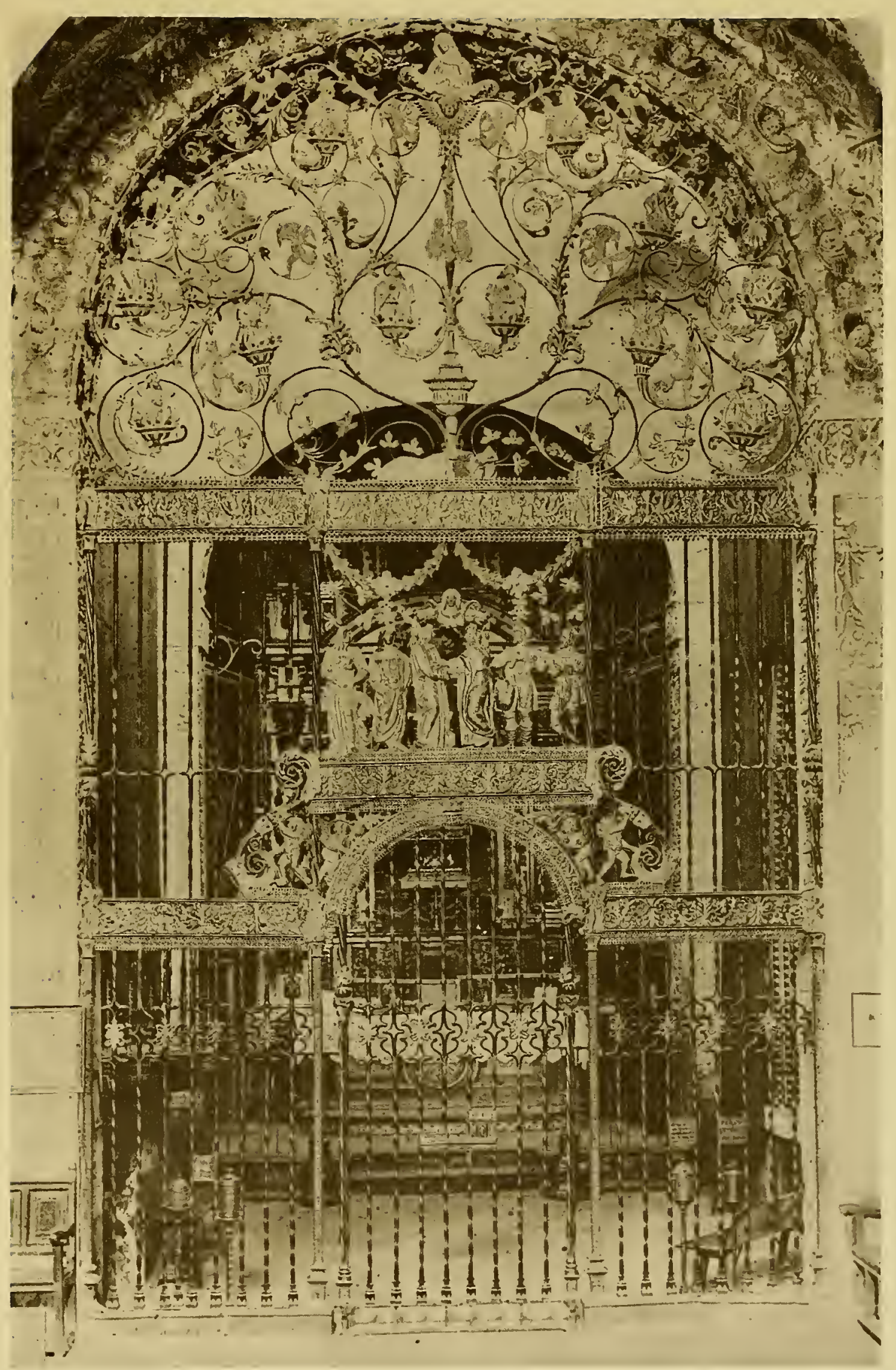





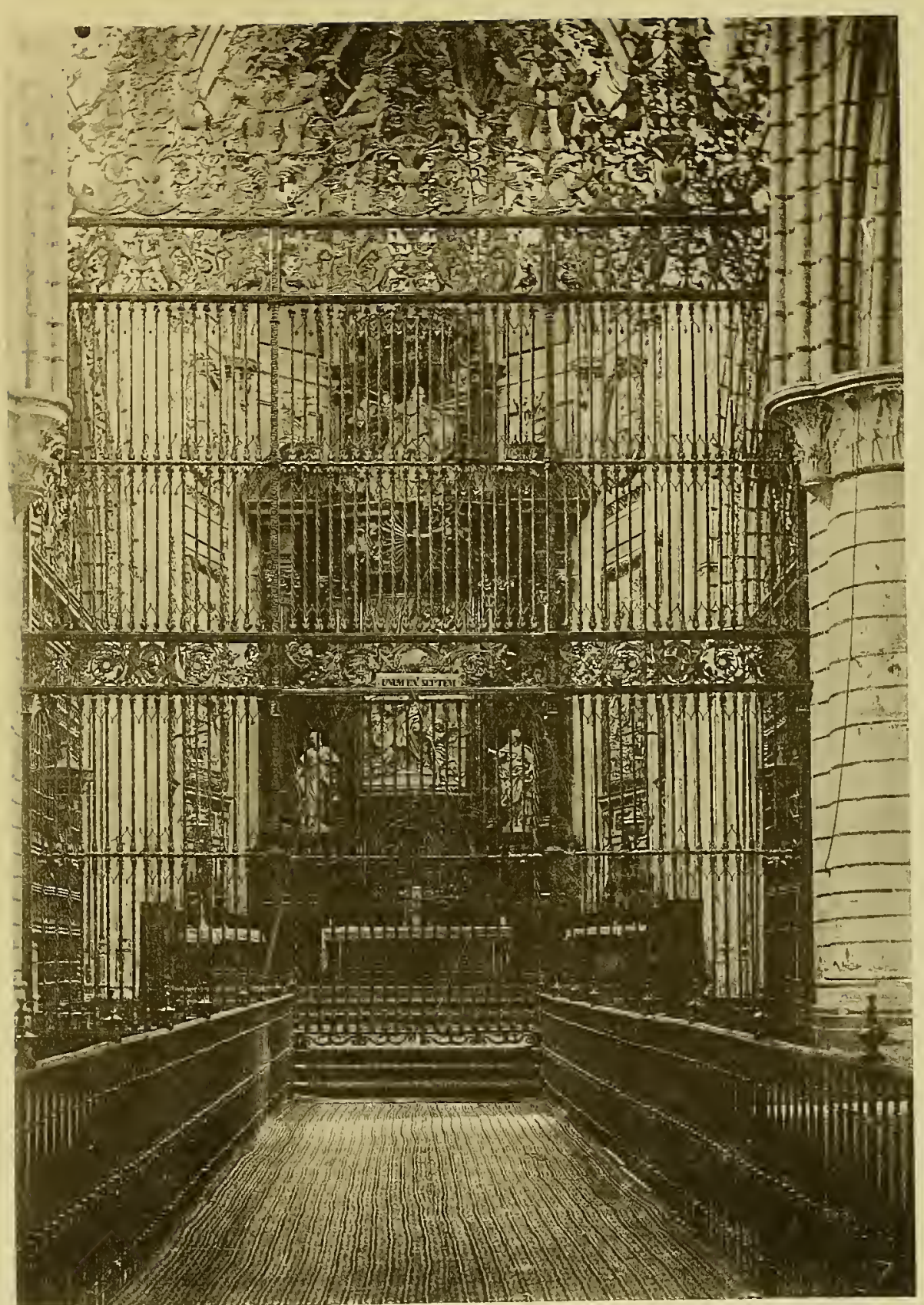

Fototipia de Hauser y Menet,-Mladrid

REJA DE LA CAPILLA MAYOR DE LA CATEDRAL DE CUENCA Autor ignorado. Siglo XVI.

(PÁG. 89) 



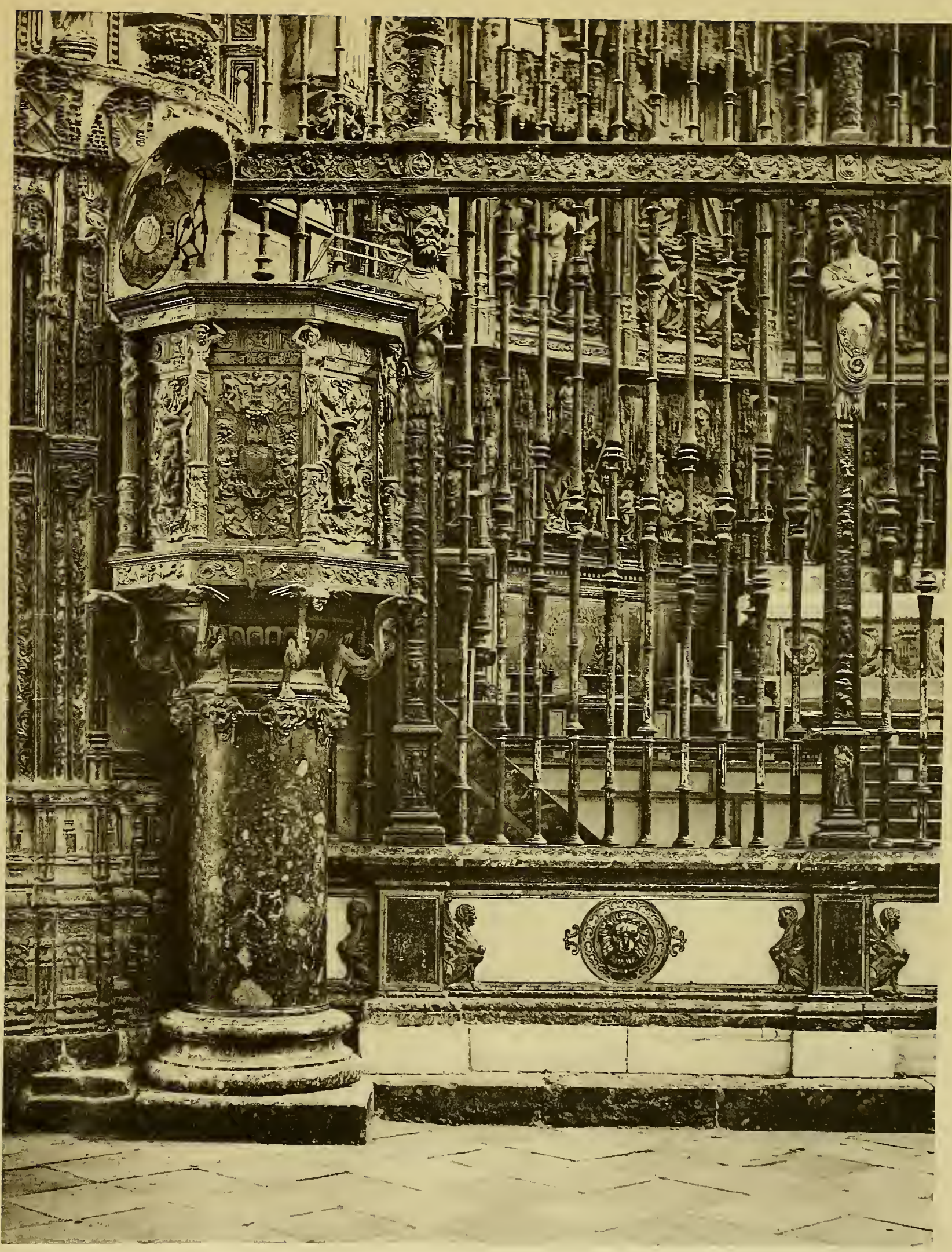





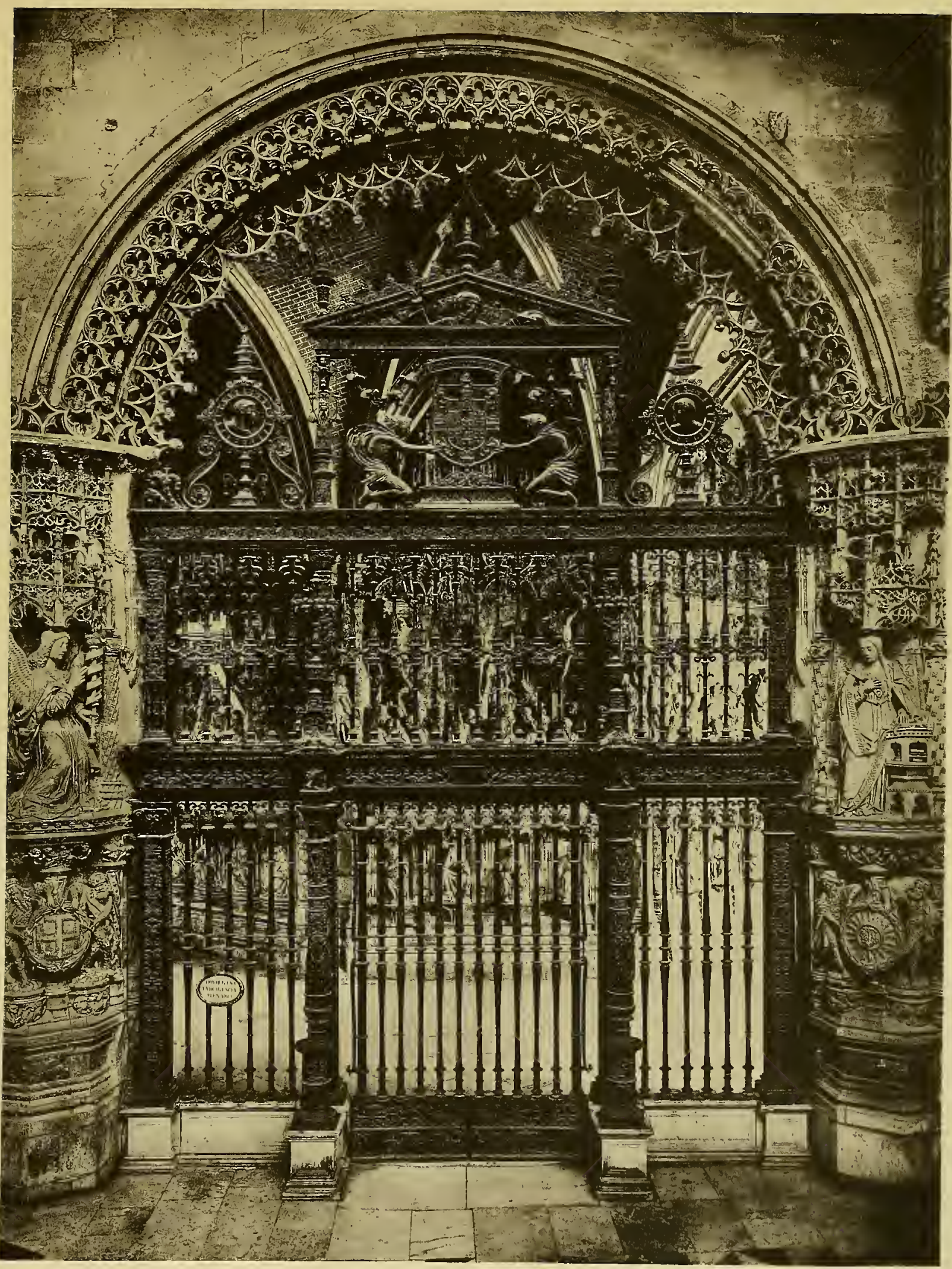

Fototipia de Hauser y Menet-Madrid

REJA DE LA CAPILLA DEL CONDESTABLE EN LA CATEDRAL DE BURGOS Obra de Cristobal Andino, terminada en 1523 



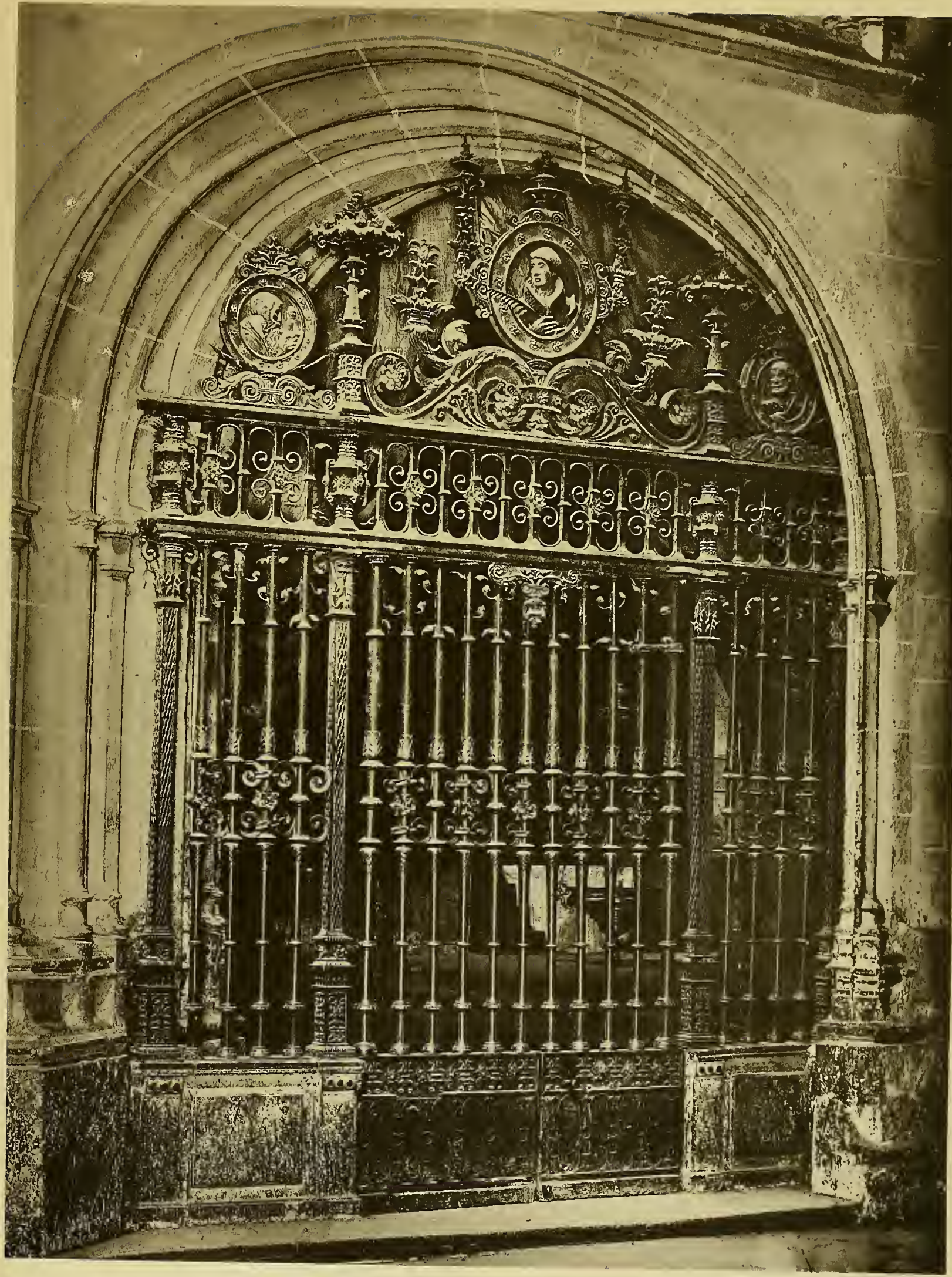

Folocipia de Hauser y Menet,-Madrid

REJA LATERAL DE LA CAPILLA MAYOR DE LA CATEDRAL DE PALENCIA Obra de Cristobal Andino. 1531 



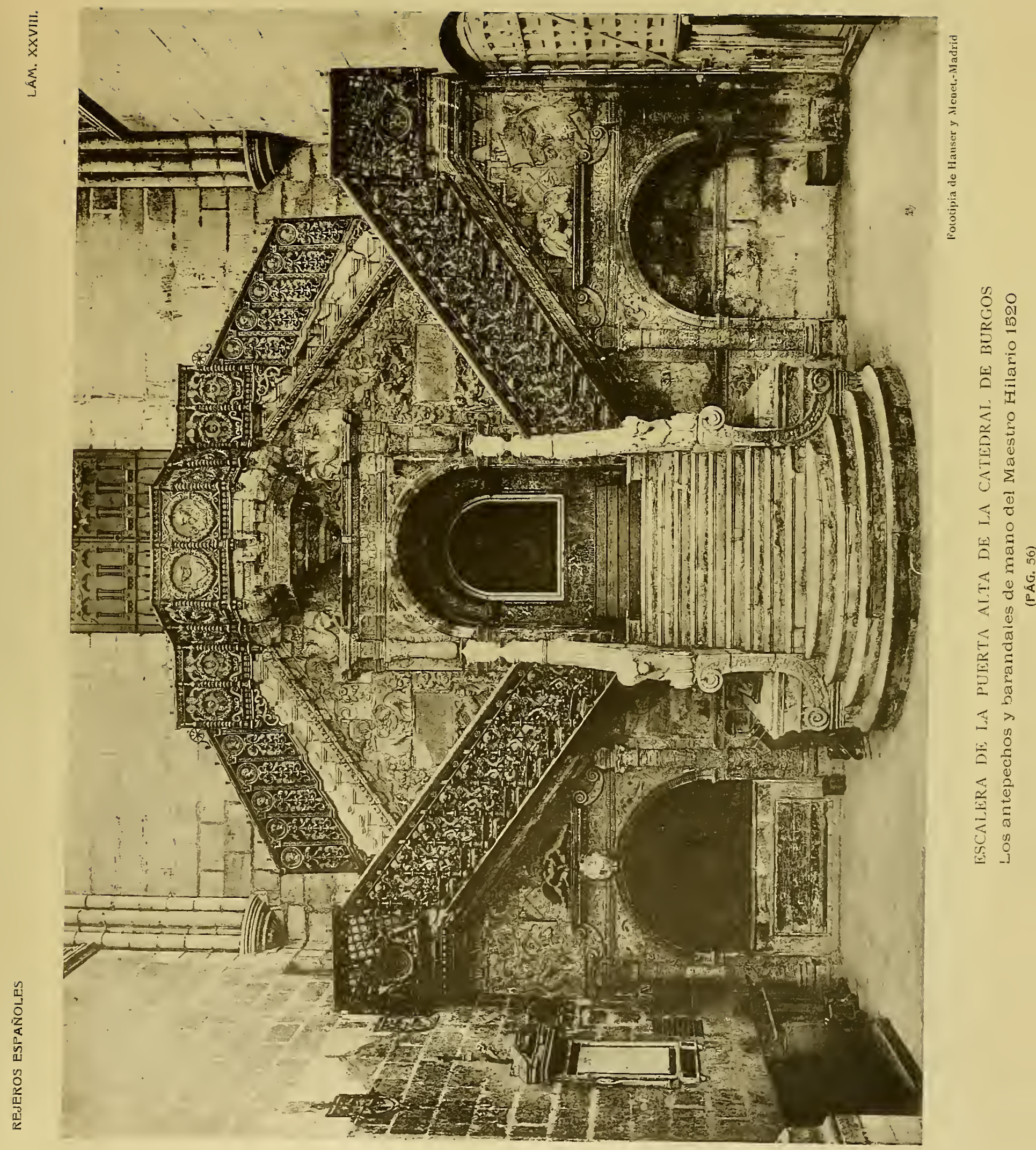





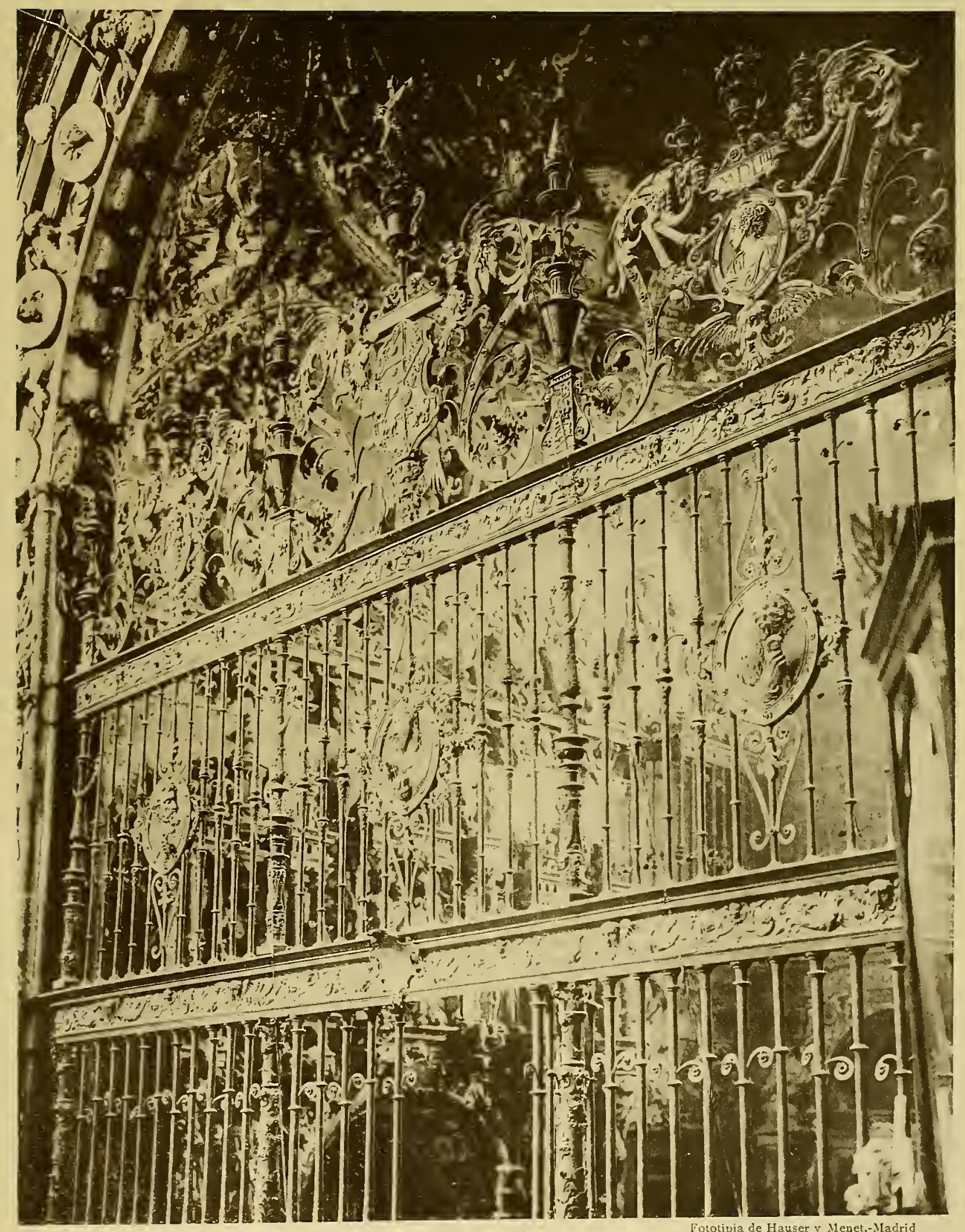

PARTE SUPERIOR DE LA REJA DE LA CAPILLA DE LOS BENAVENTES EN LA IGLESIA DE SANTA MARIA, DE MEDINA DE RIOSECO 



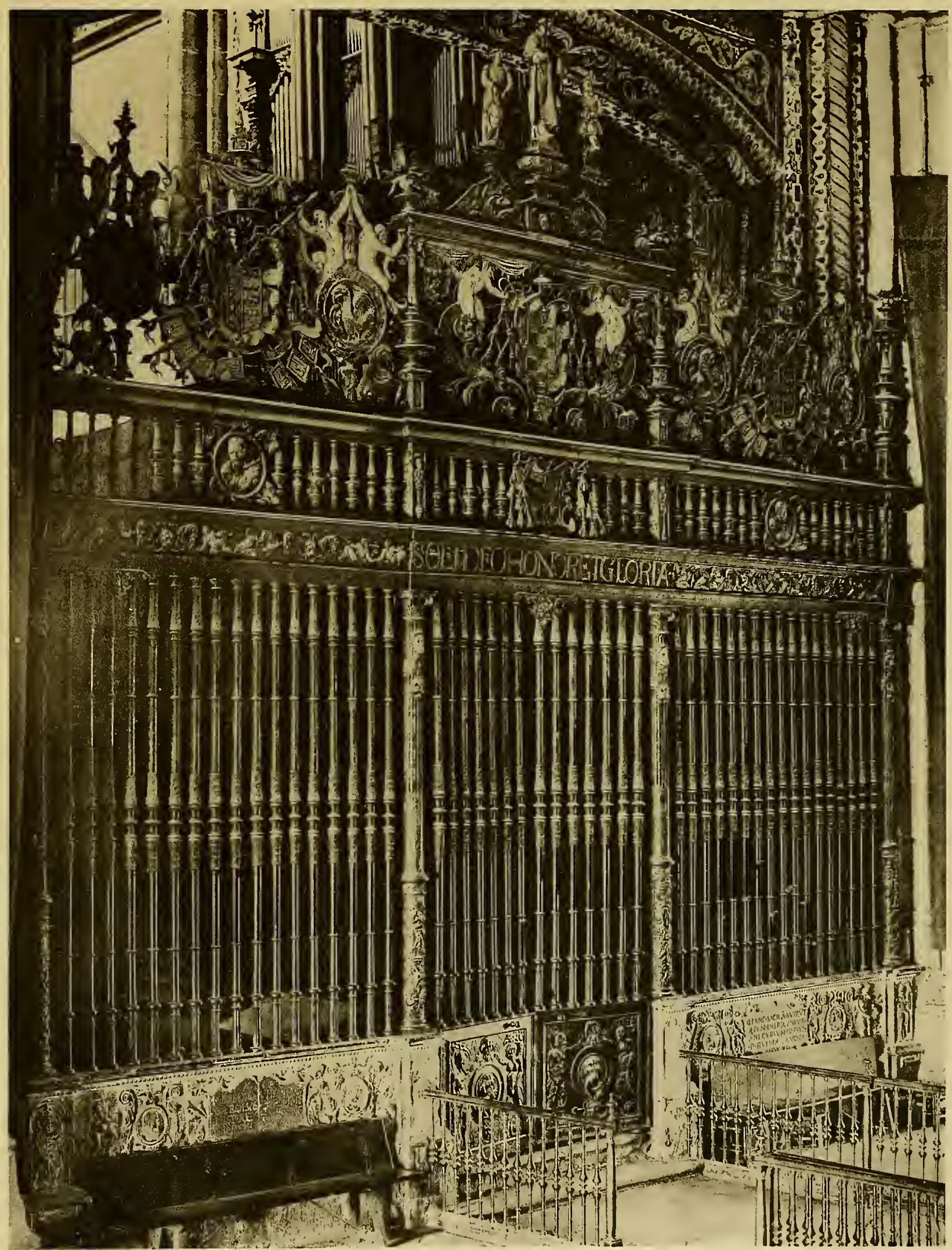

Fot. Lacoste 



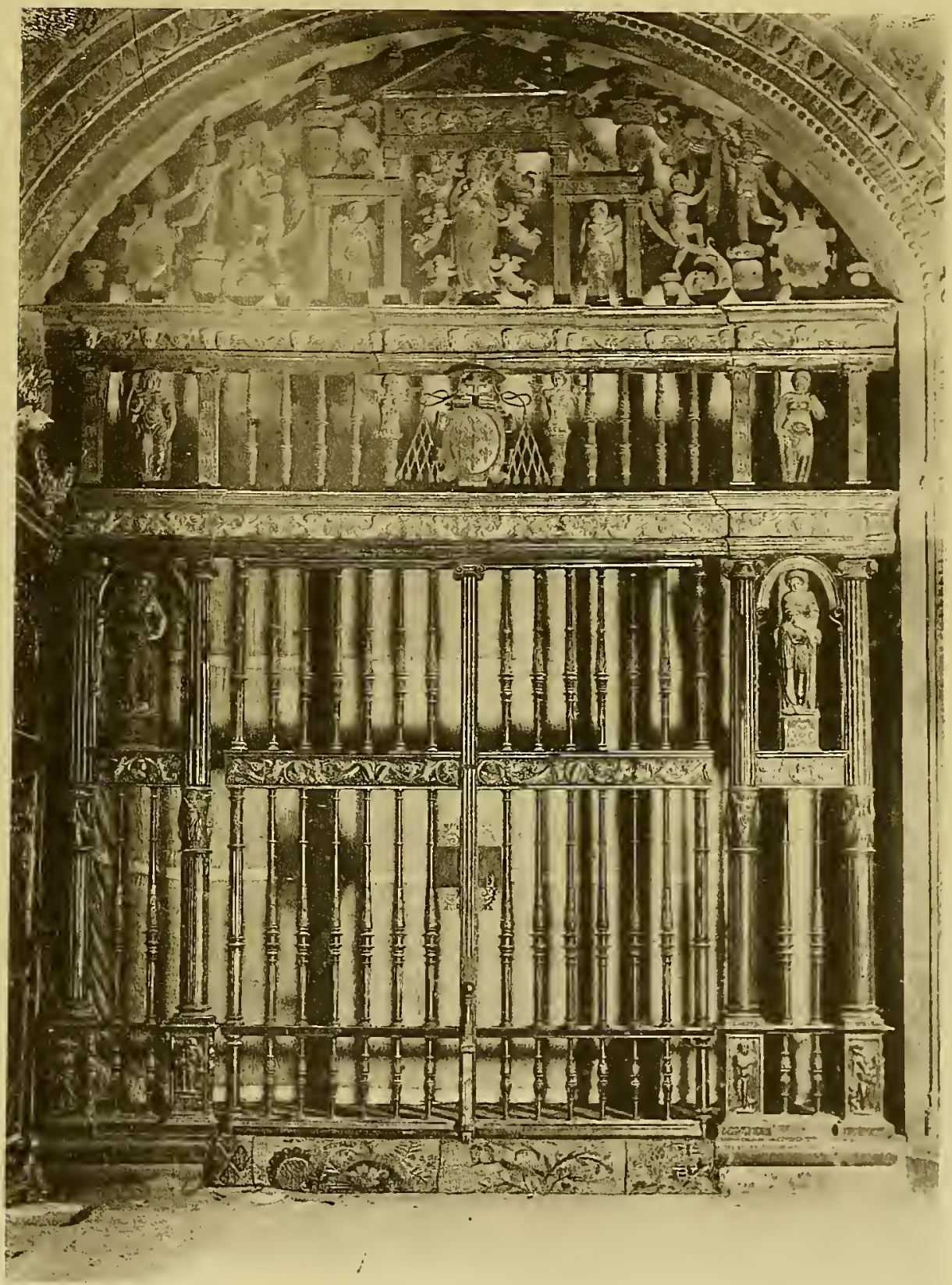

Fototipia de Hauser y Menet,--Madrid

REJA DE LA CAPILLA ILAMADA DE LAS RELIQUIAS EN LA SACRISTIA DE LA CATEDRAL DE SIGÜENZA

Obra de Hernando de Arenas. Siglo XVI.

- (PÁG. 61) 



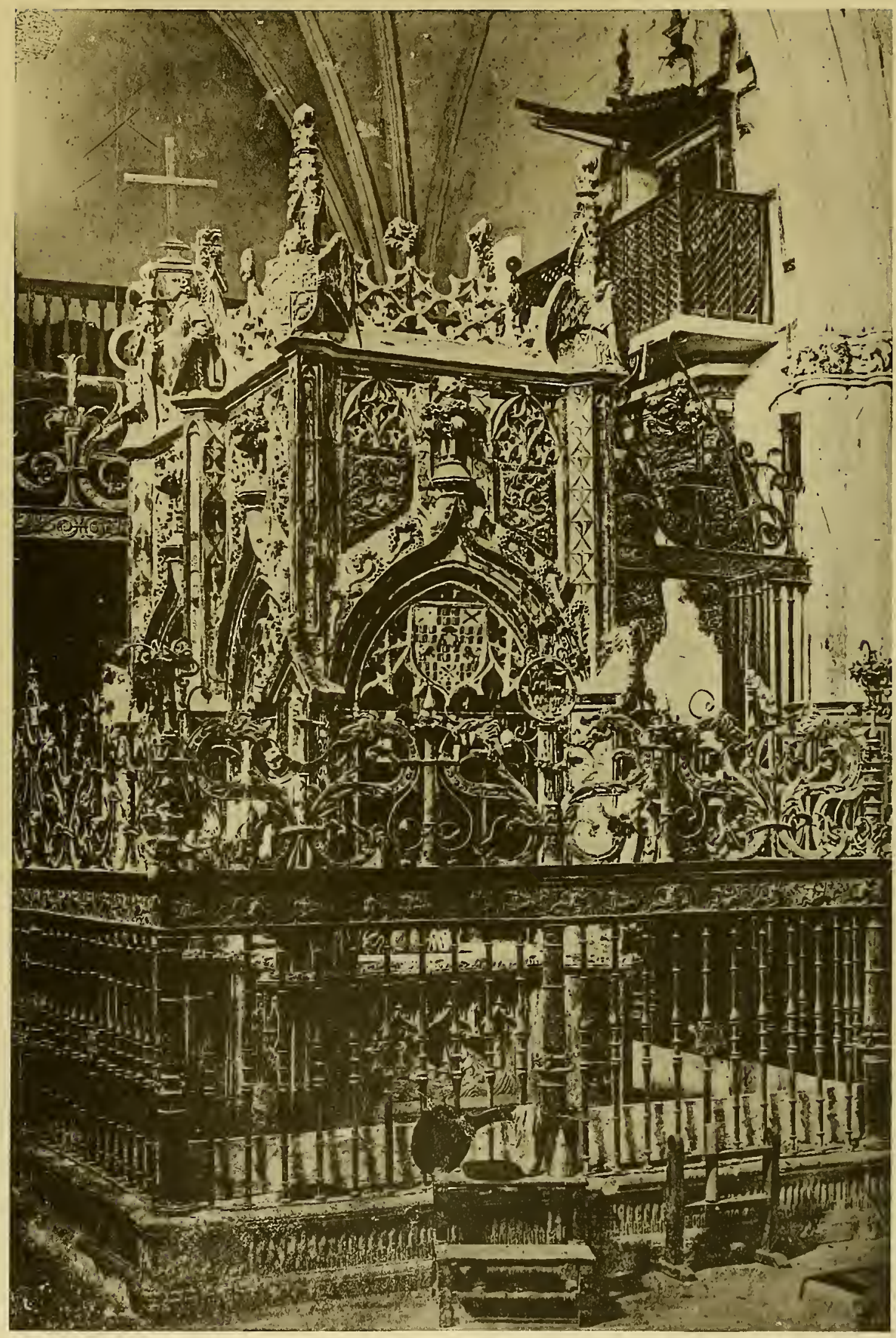

Pololipia de Hauser y Menet.-Madrid

VERJA DEL SEPULCRO DE SAN JUAN DE ORTEGA EN SU IGLESIA

(Provincia de Burgos). Siglo XVI. 



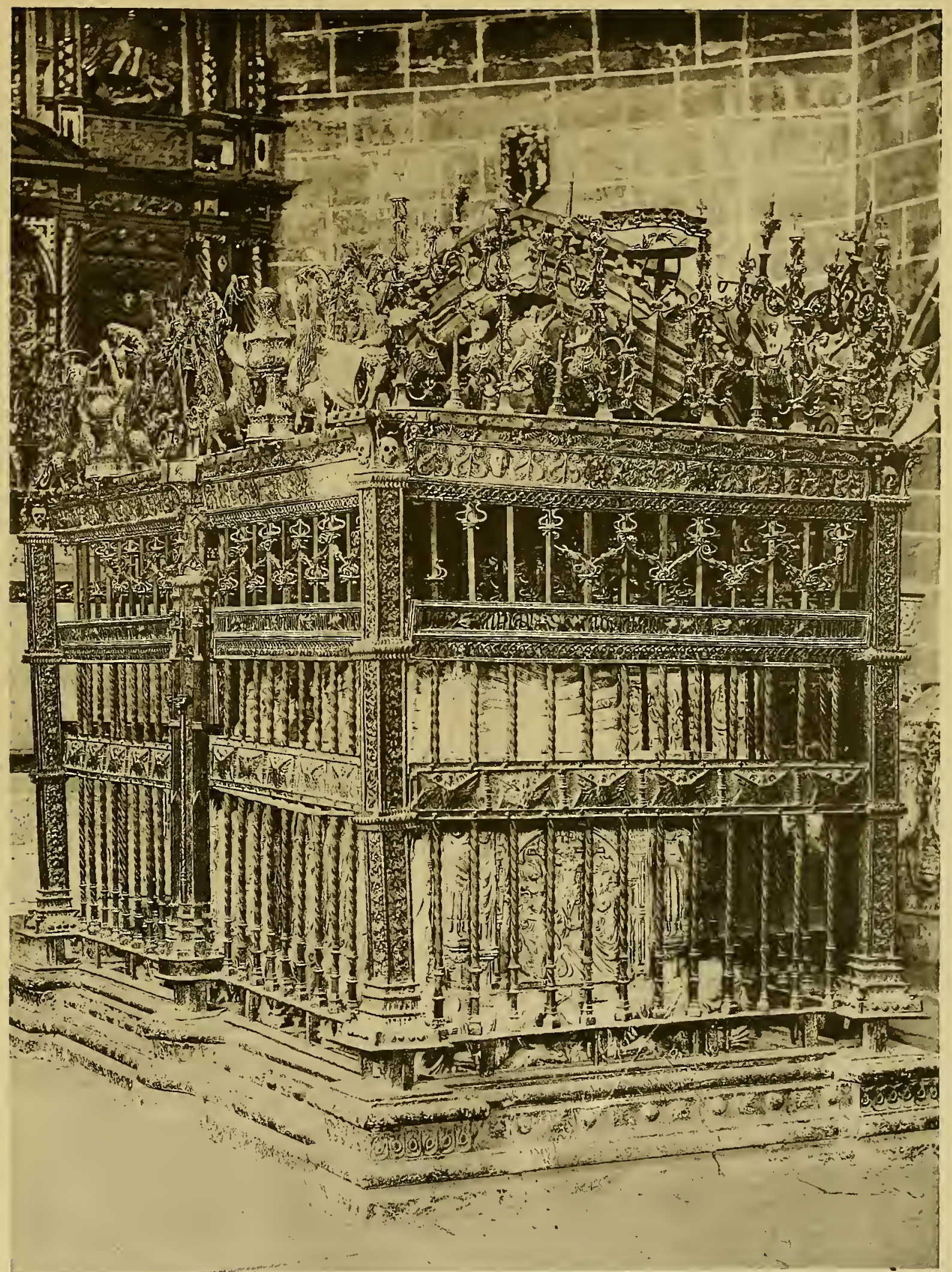





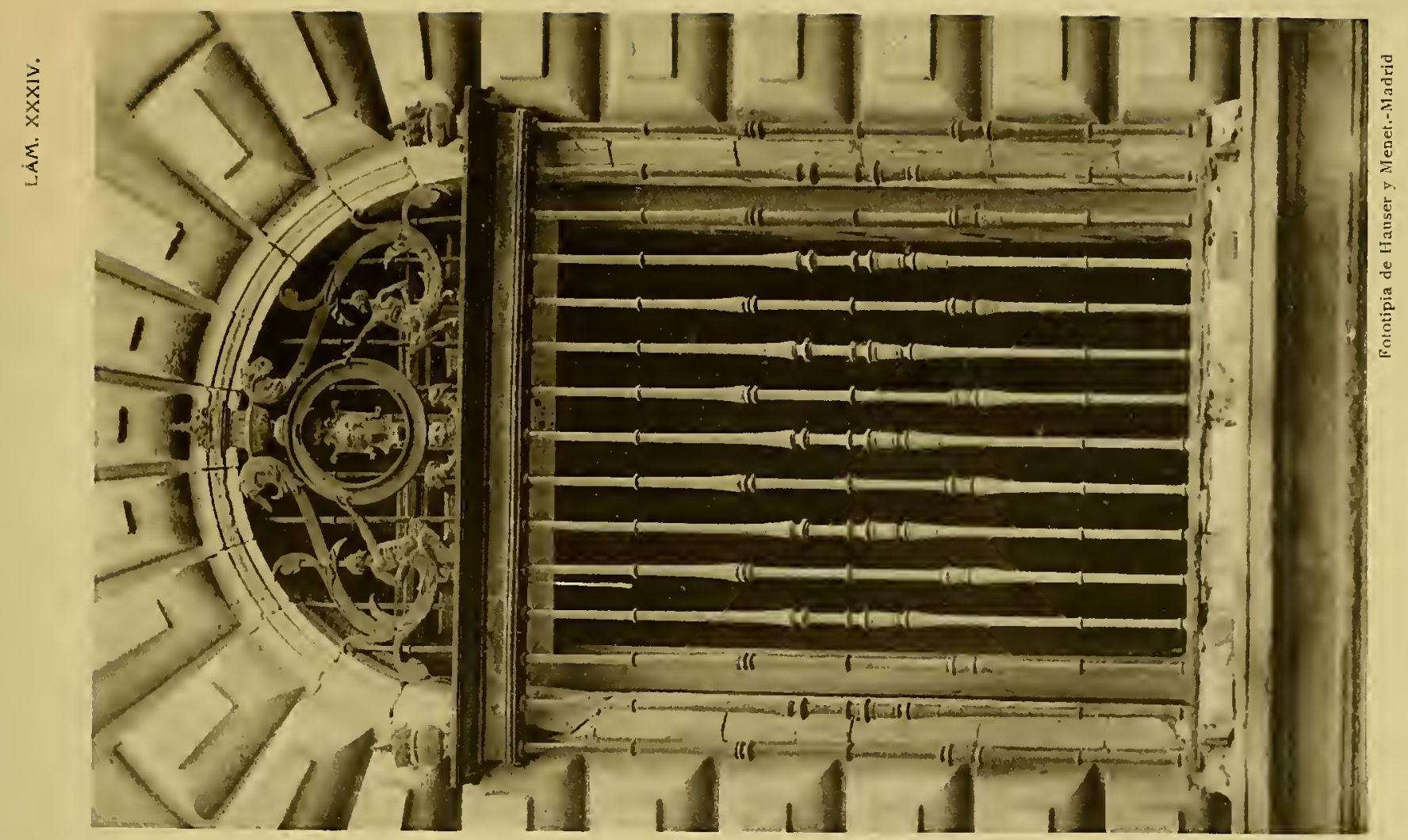

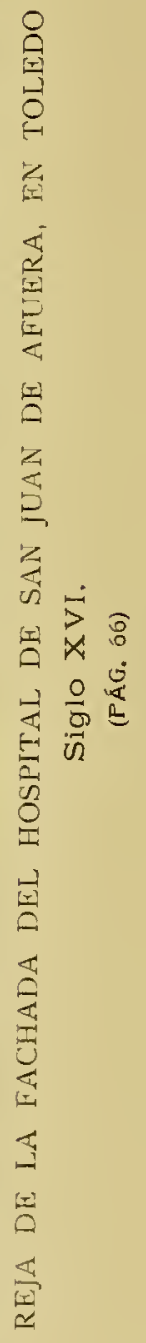

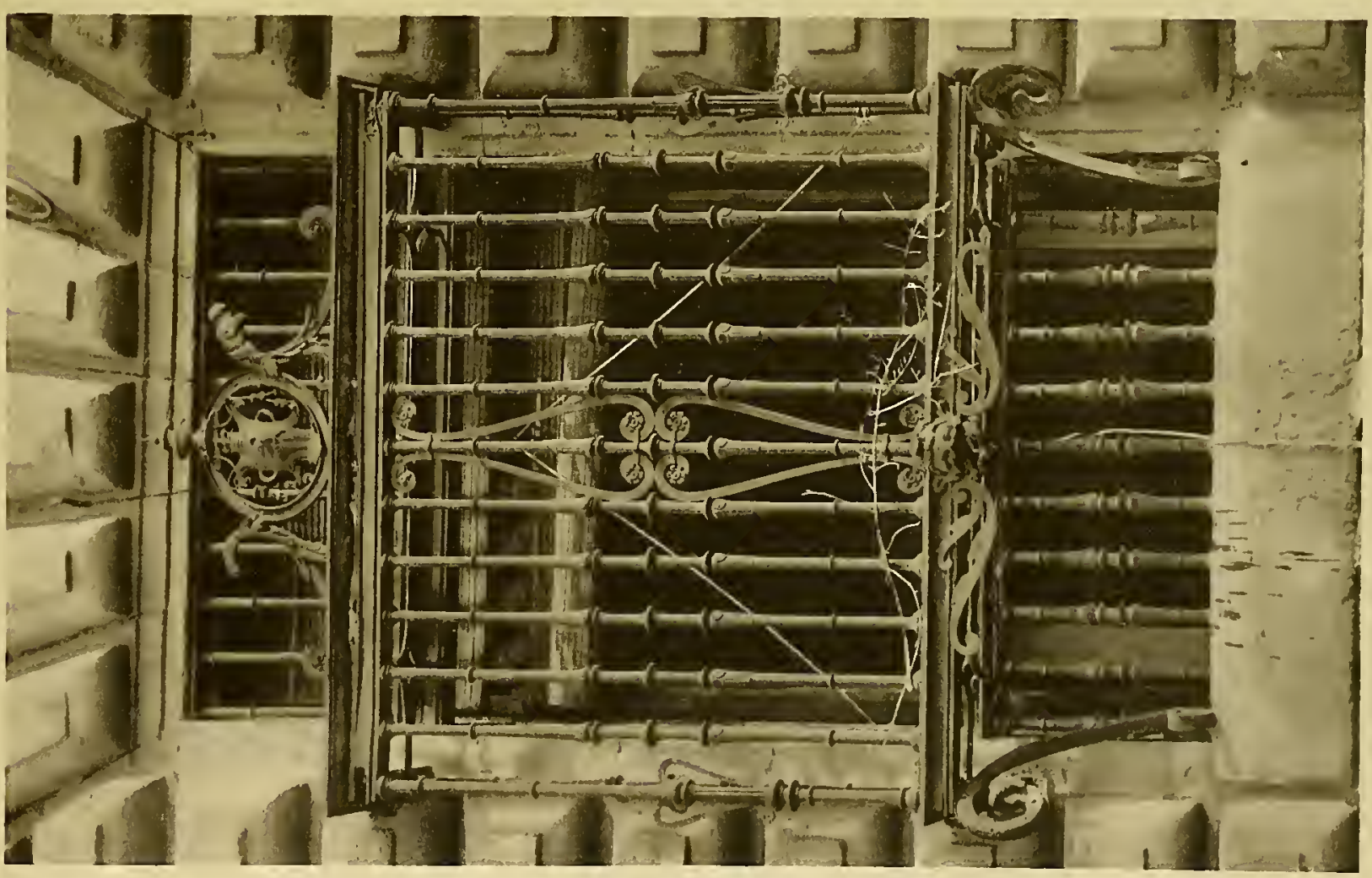





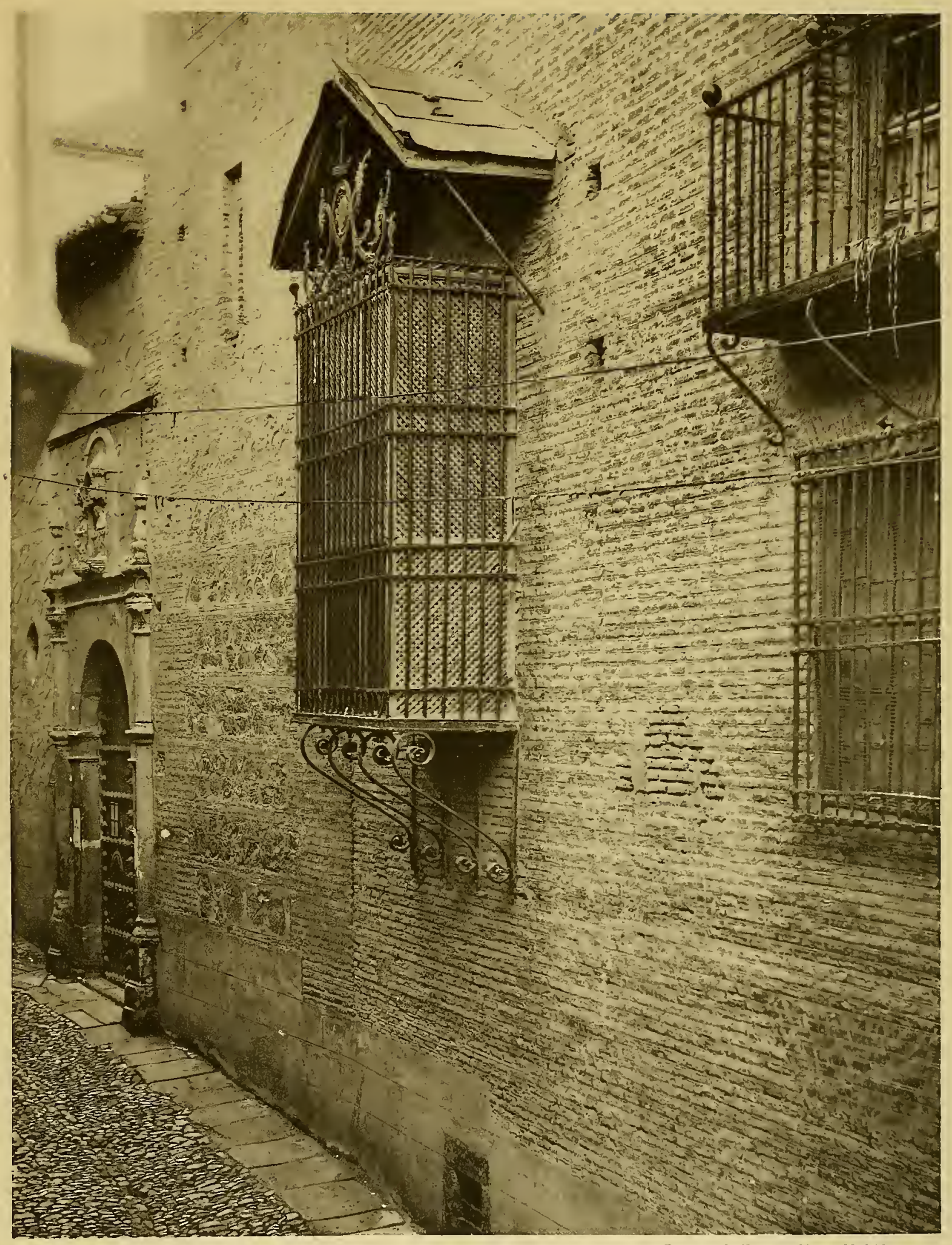

Fototipia de Hauser y Menet.-MIadrid

REJA DEL CONVENTO DE LA MAGDALENA EN TOLEDO Siglo XVI.

(PÁG, 67) 


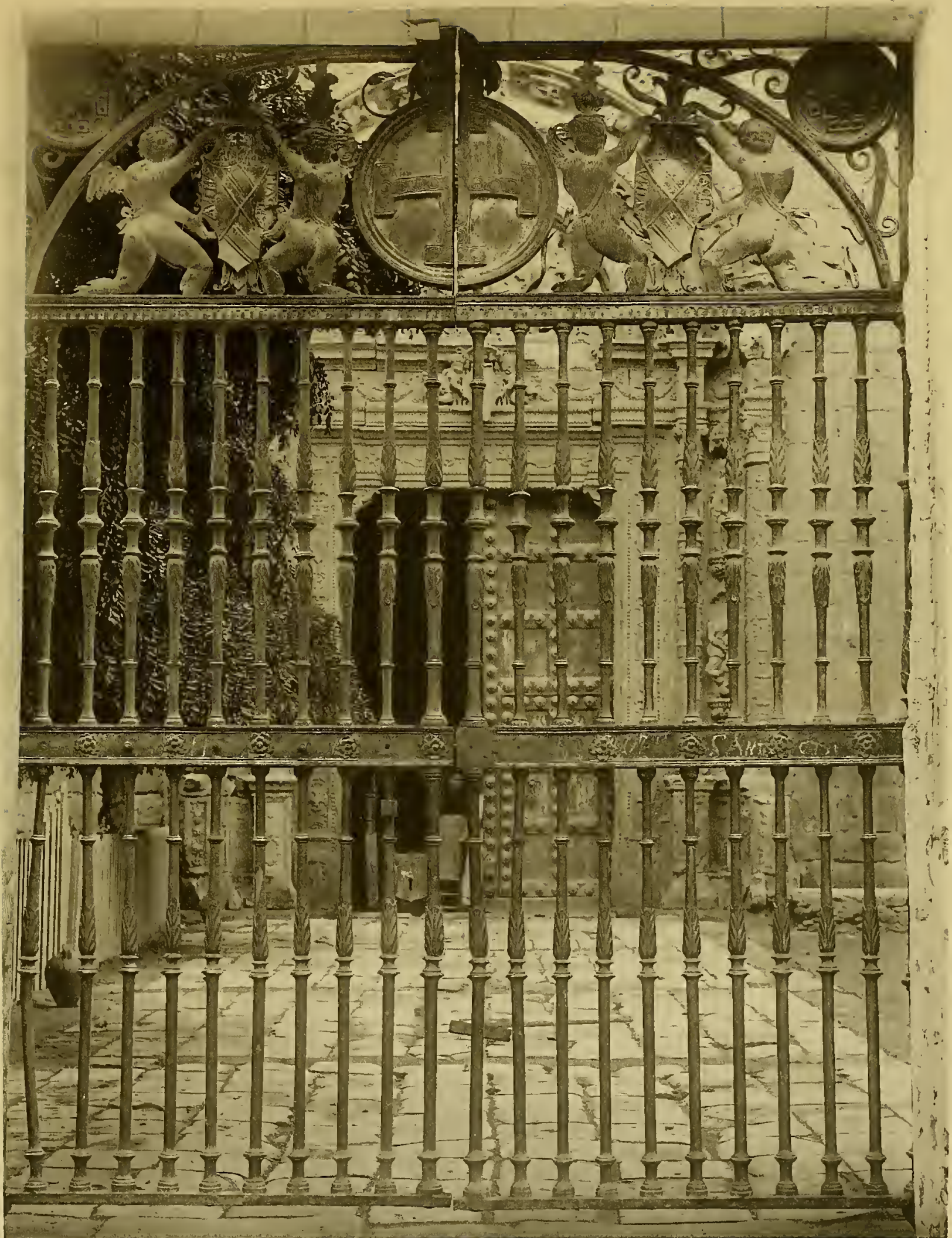

Fototipia de Hauser y .llenet.-Madrid

CANCELA EXTERIOR DE SANTA CRUZ EN TOLEDO Siglo XVI. 



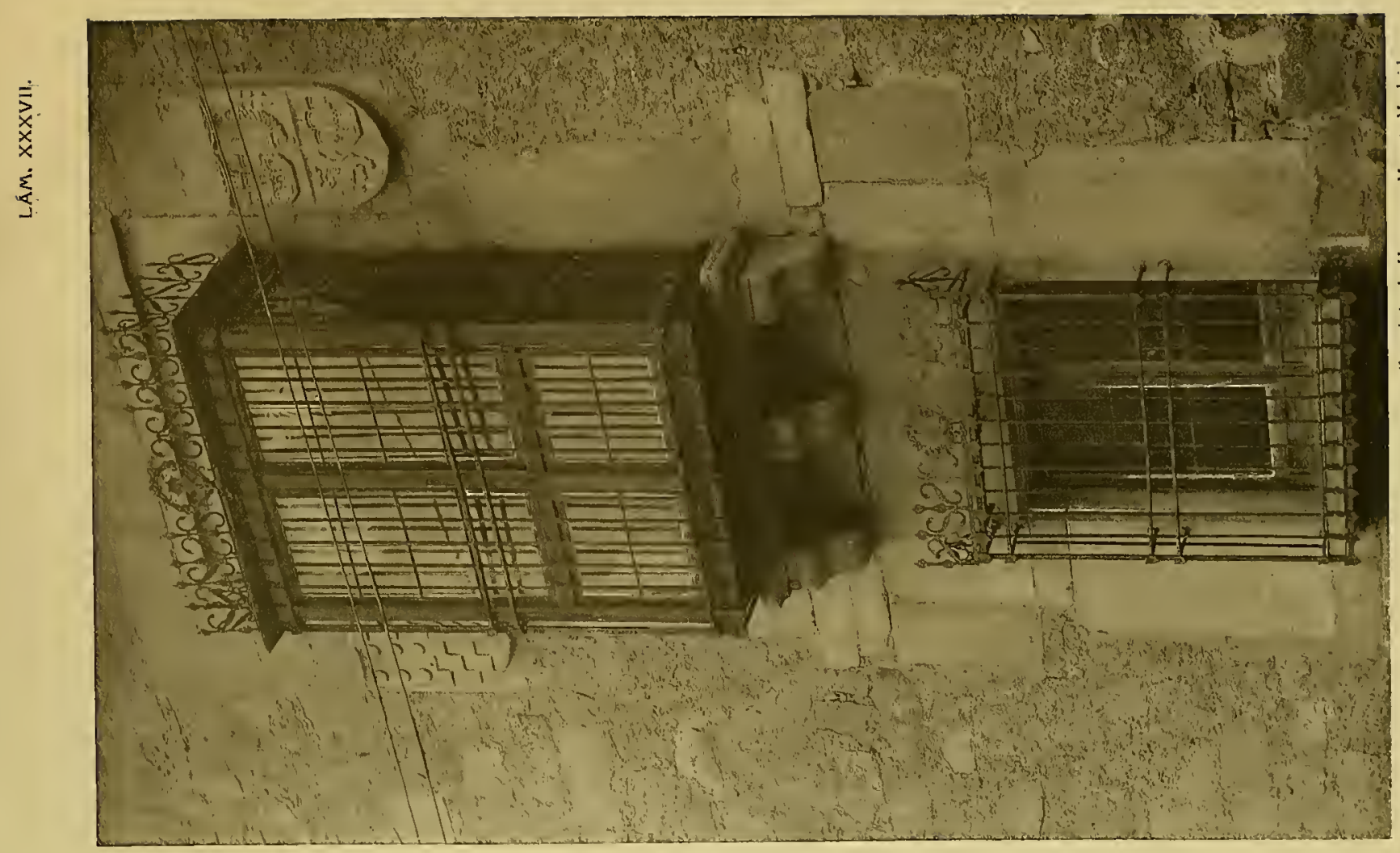

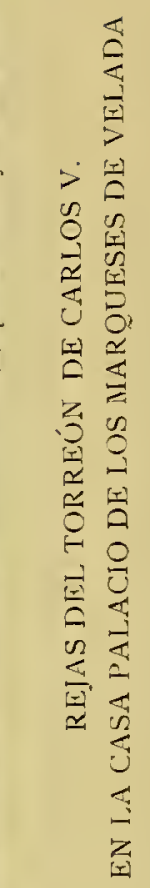

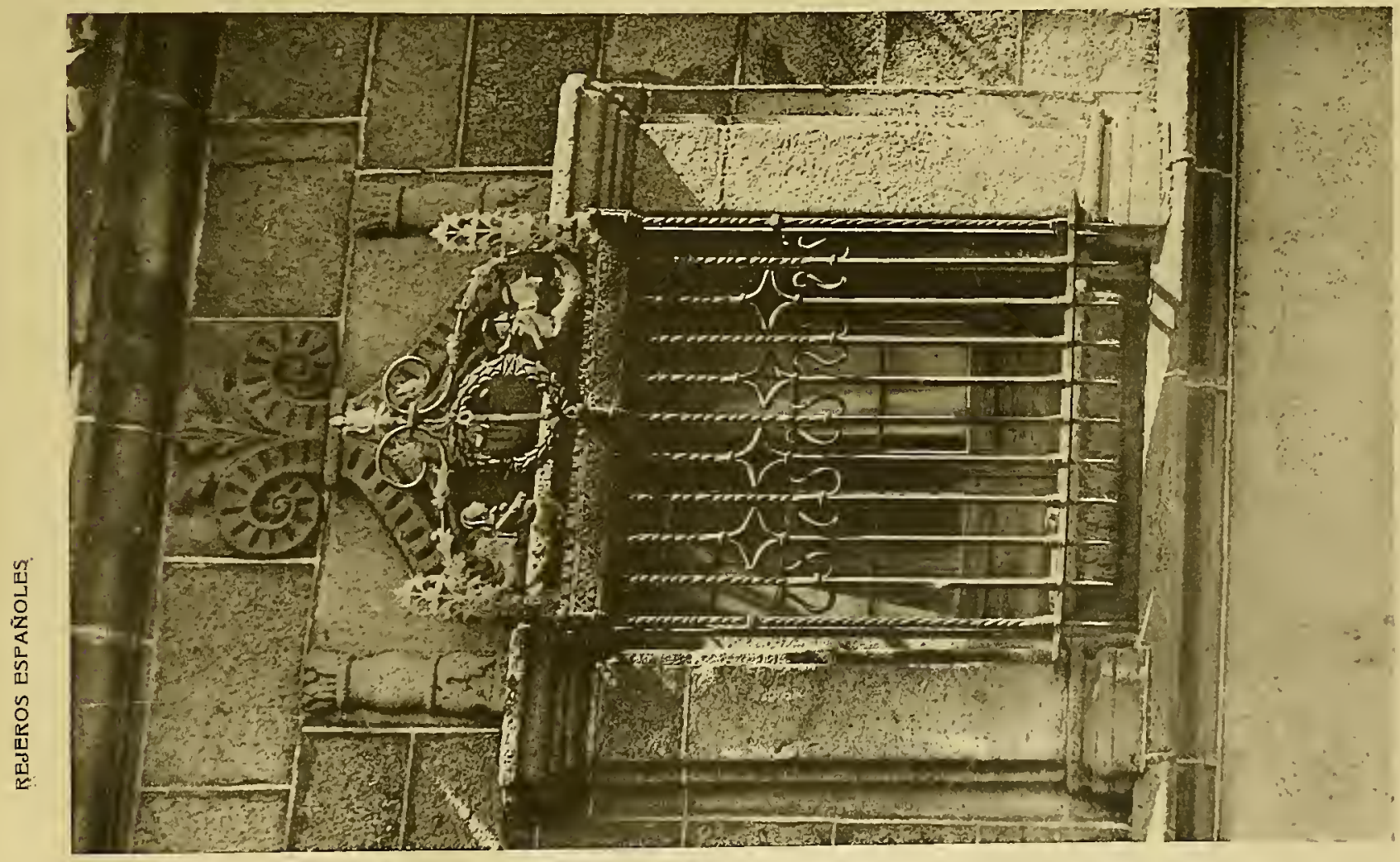

$\stackrel{5}{3}$

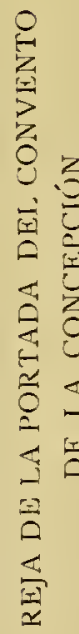





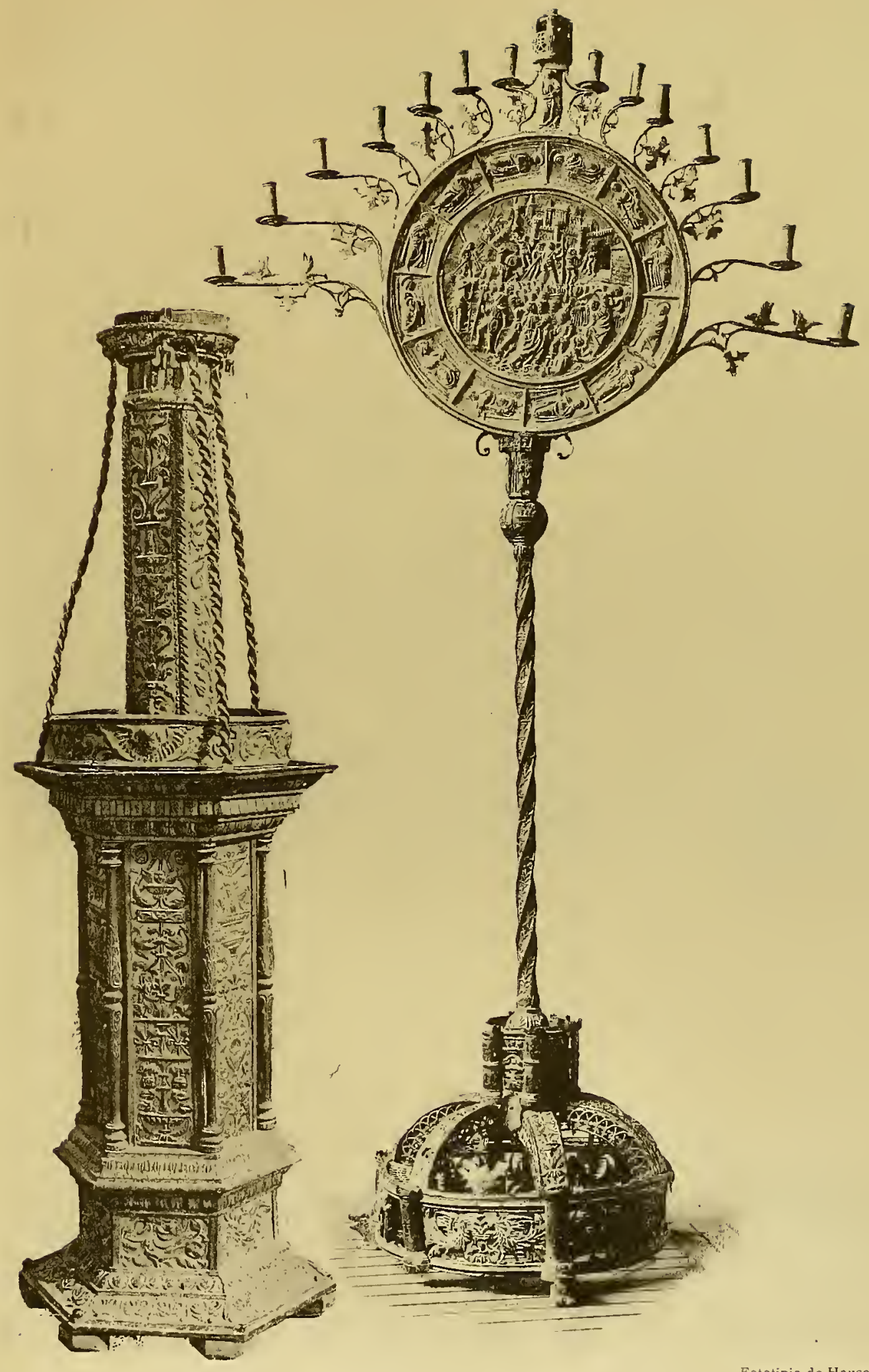

TENEBRARIO Y BLANDON DEL CIRIO PASCUAL DE LA CATEDRAL DE JAEN Siglo XVI.

(PÁG. 68) 


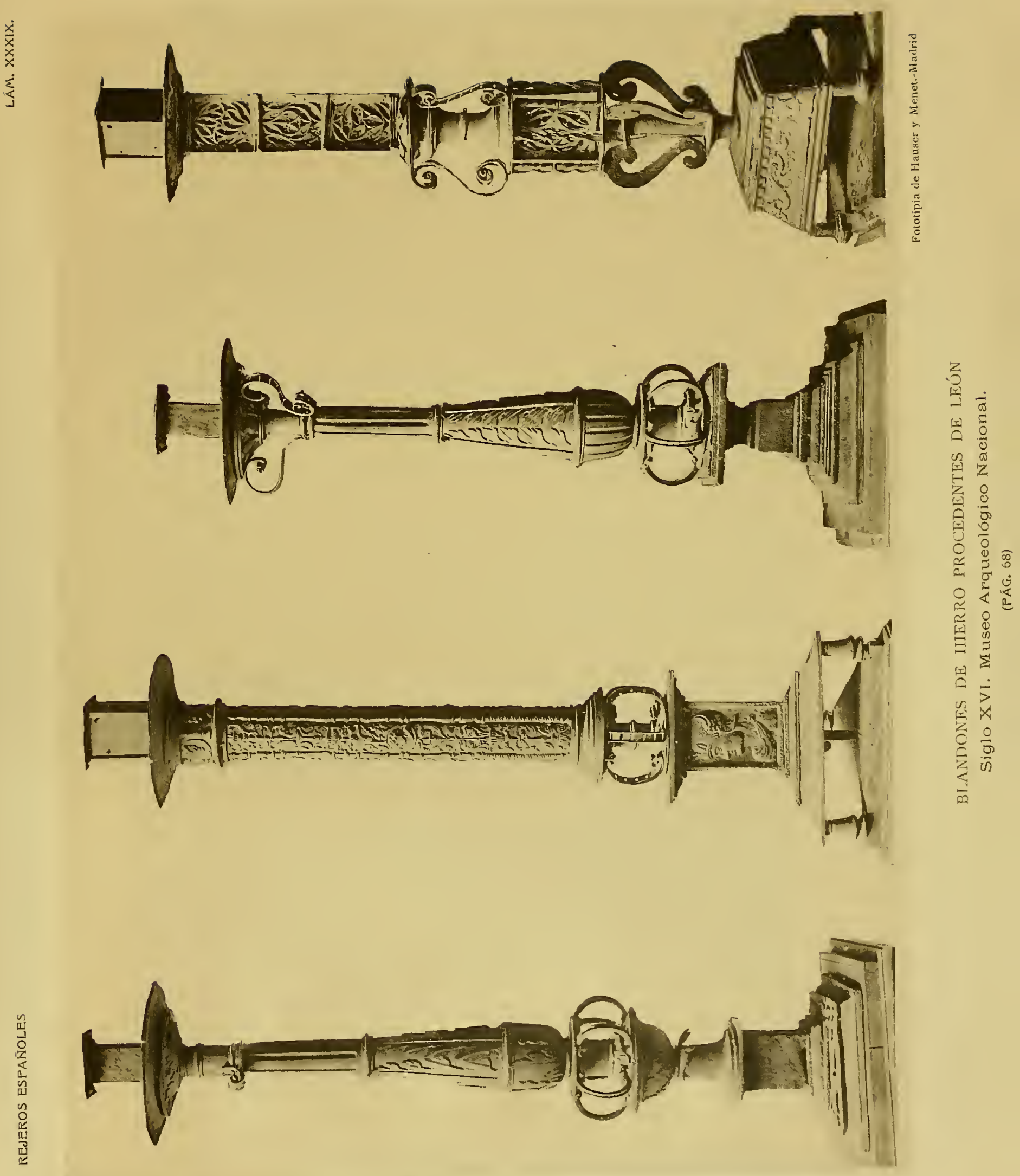



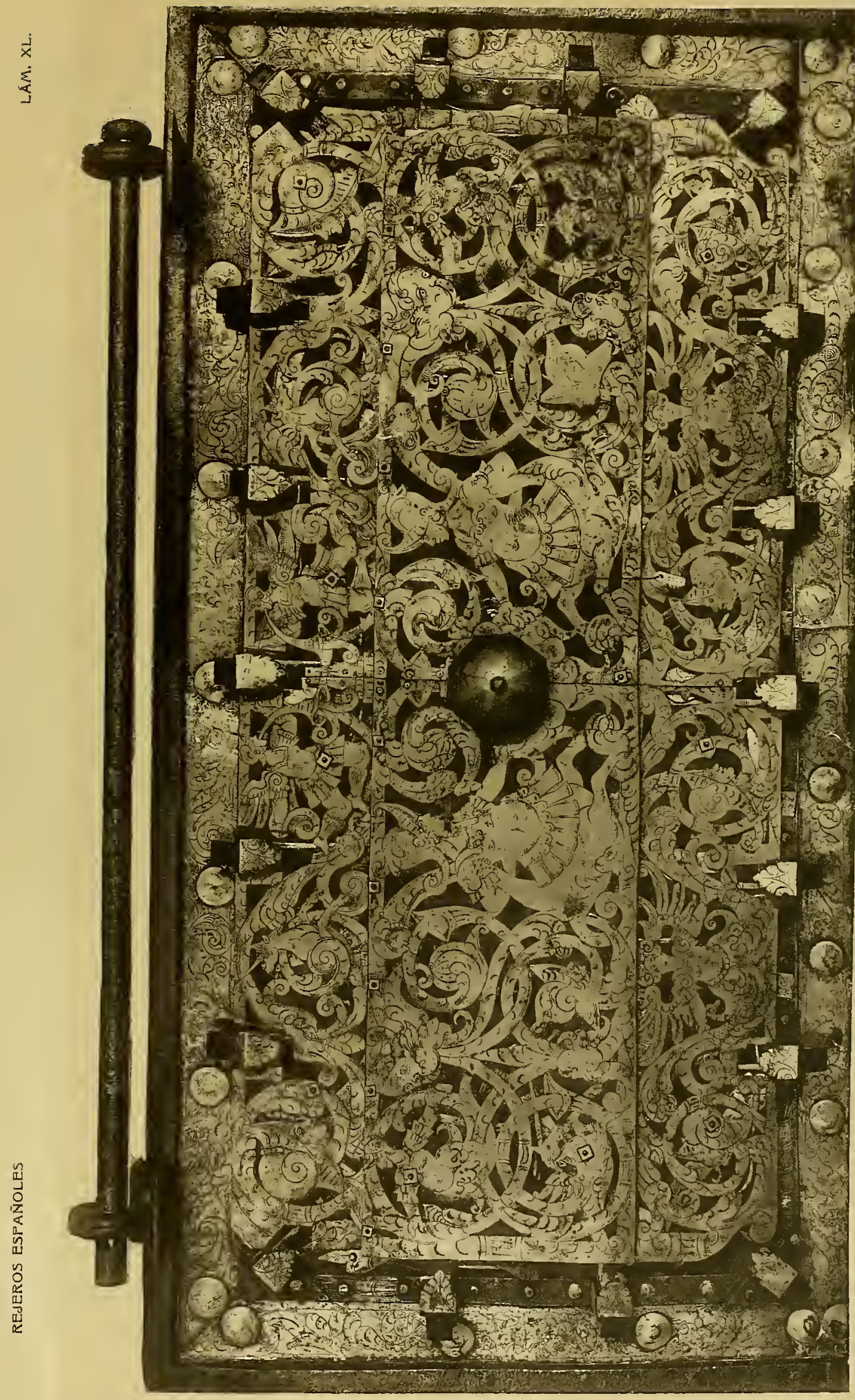





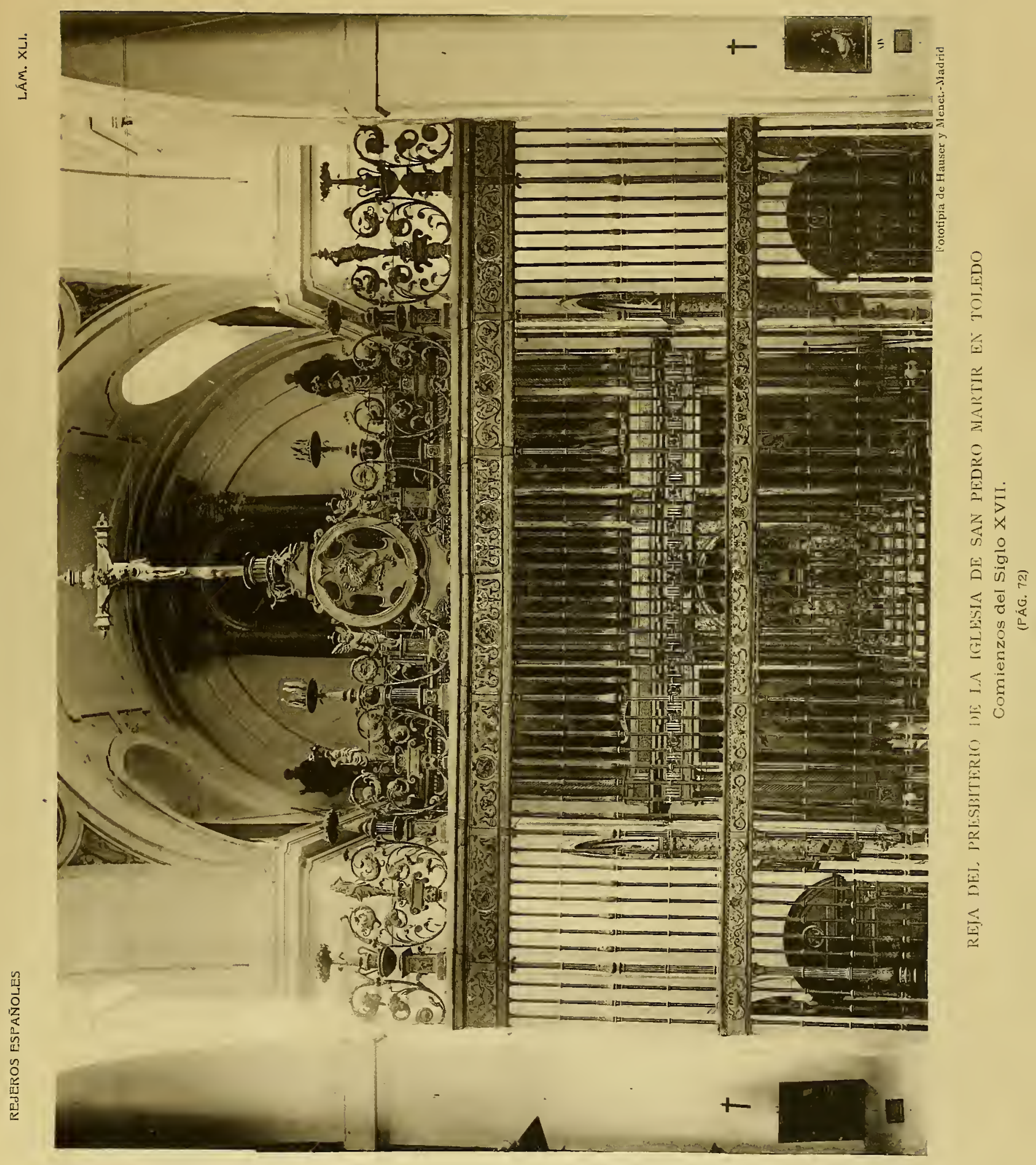





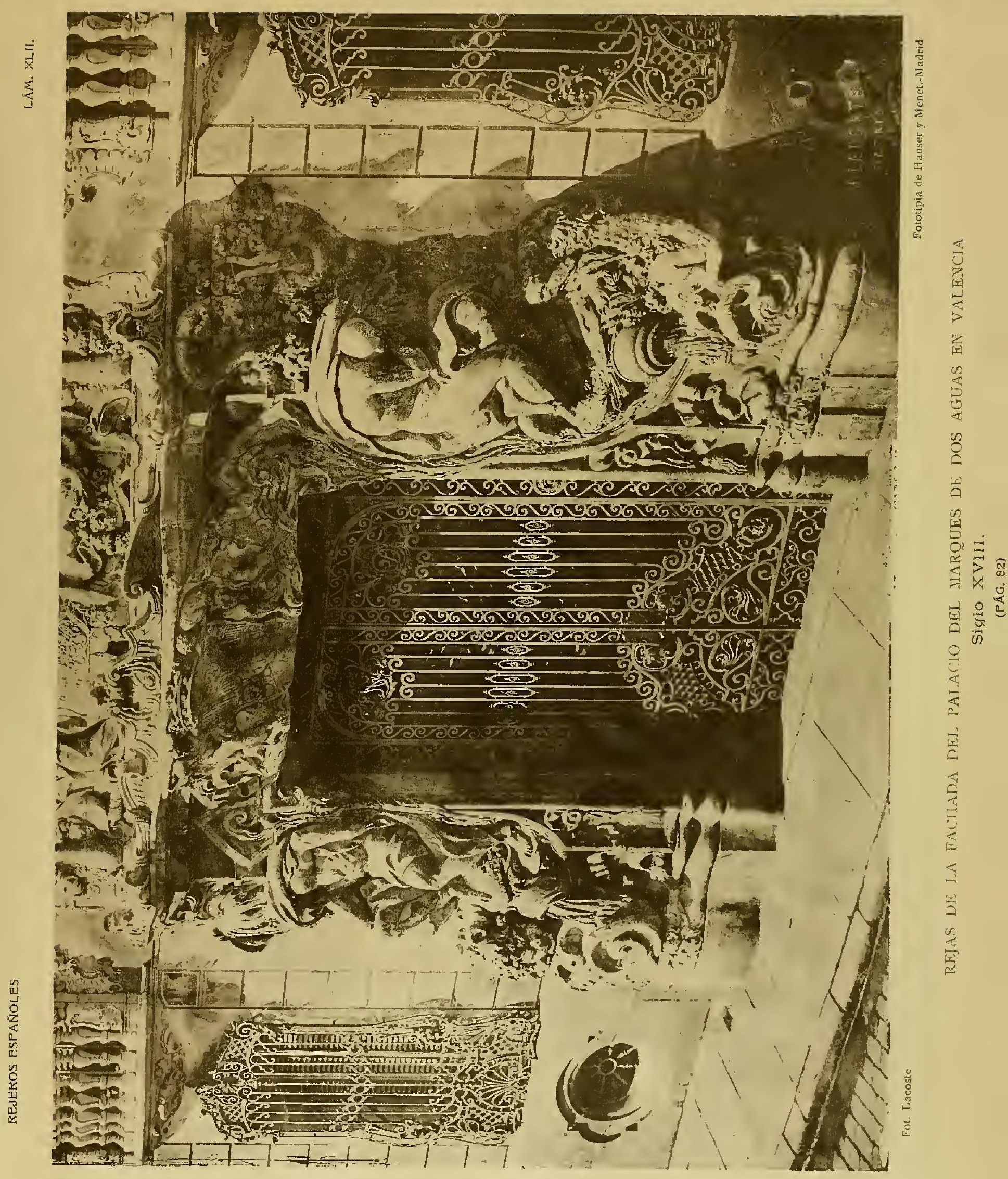





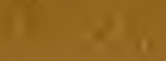

$x_{0}$

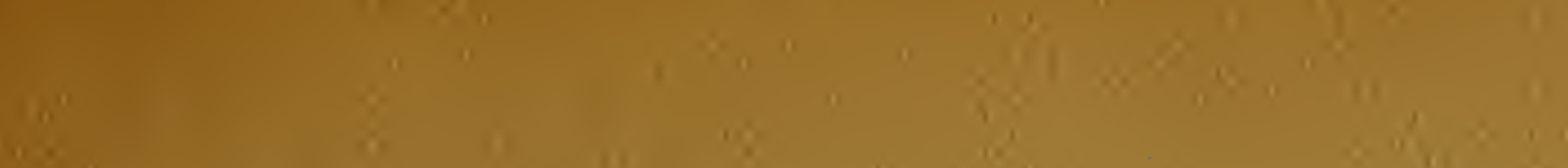

$x^{2}+0^{2}+1$

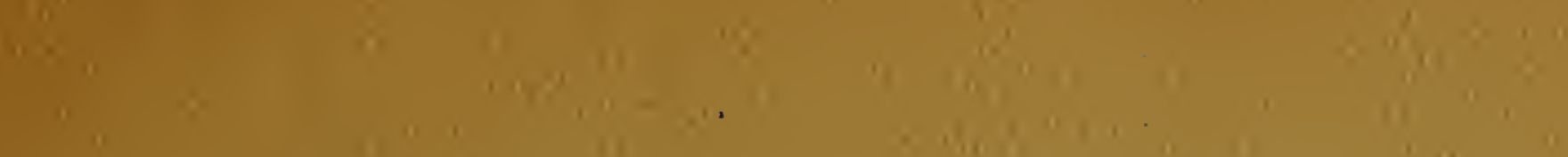

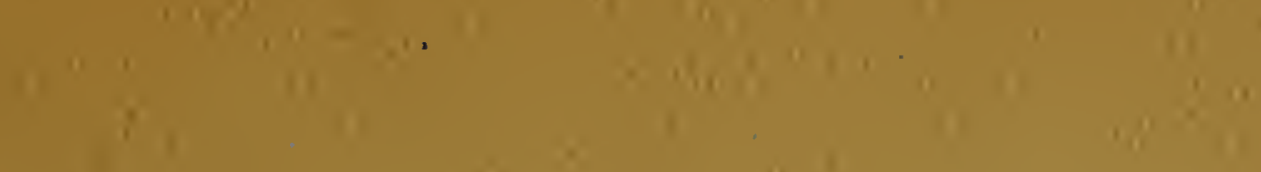

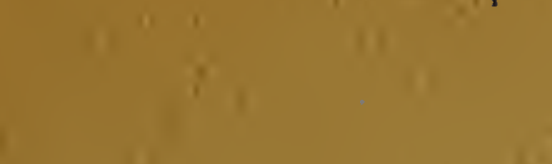

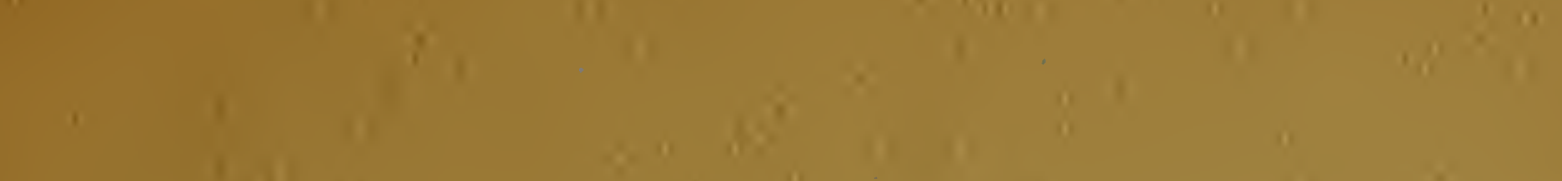

(1) 8

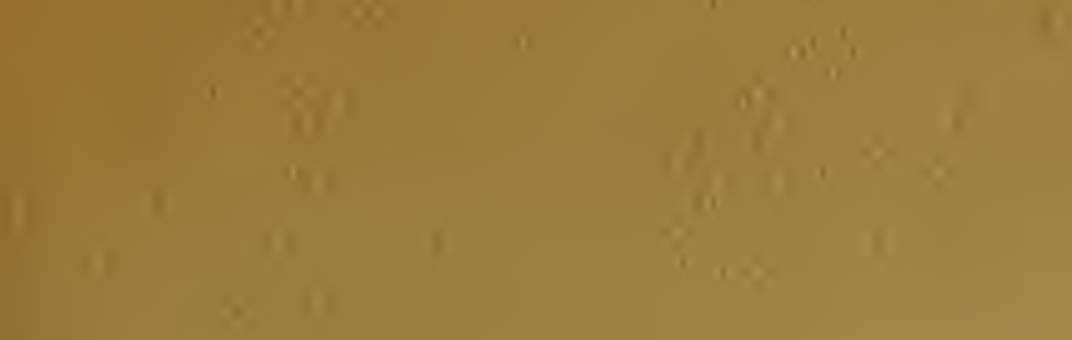

(1)

in

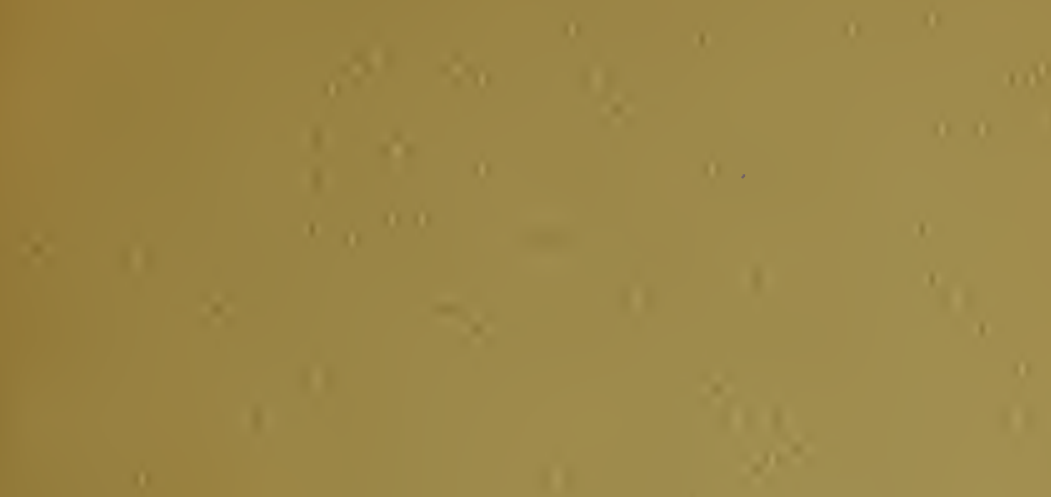

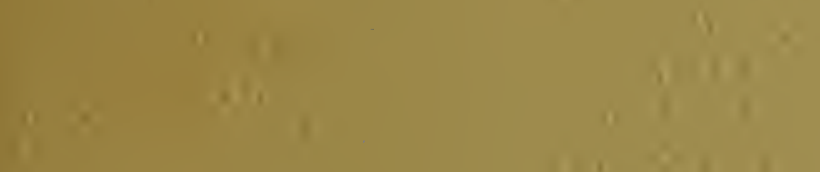

$1,8,1$

(1)

11
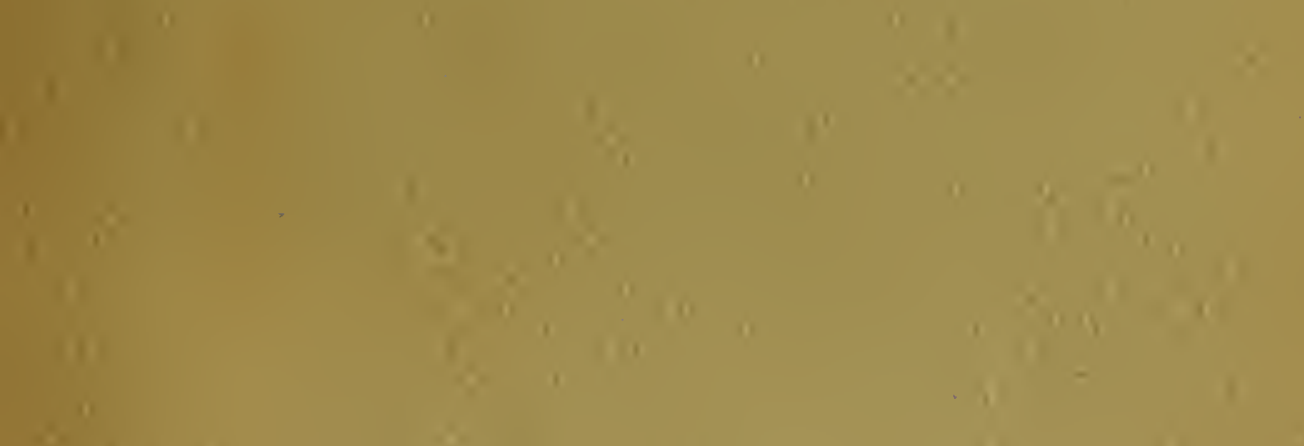

ins

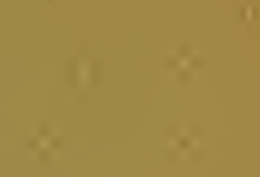

(1)

(1)

8. $x$

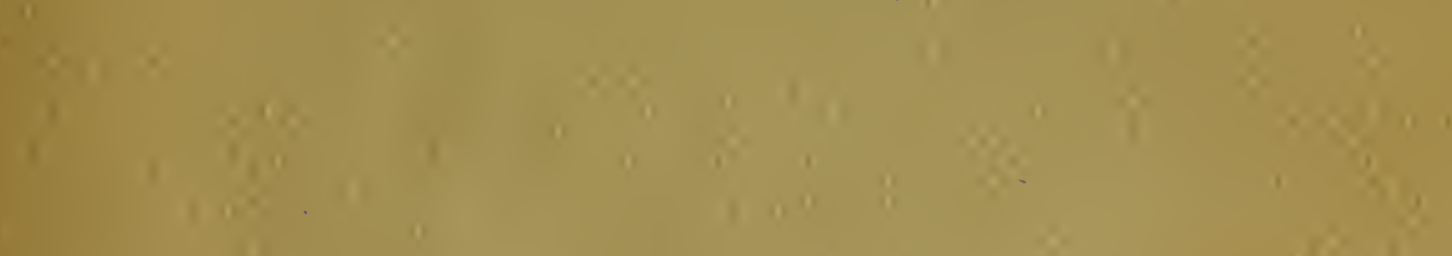

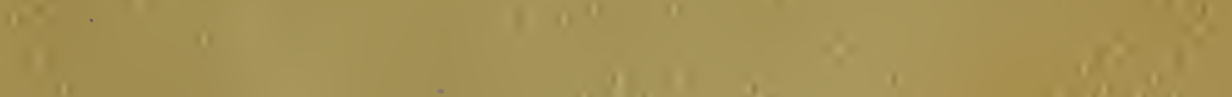

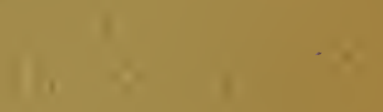

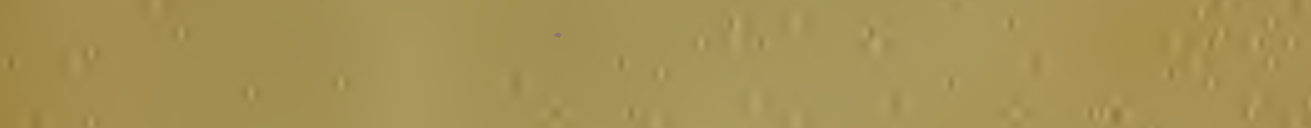

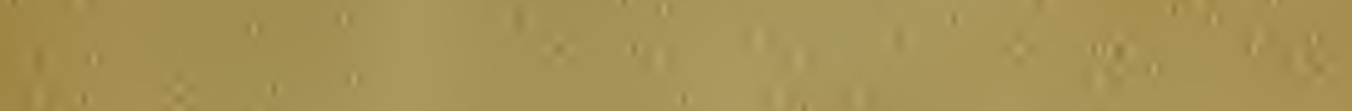

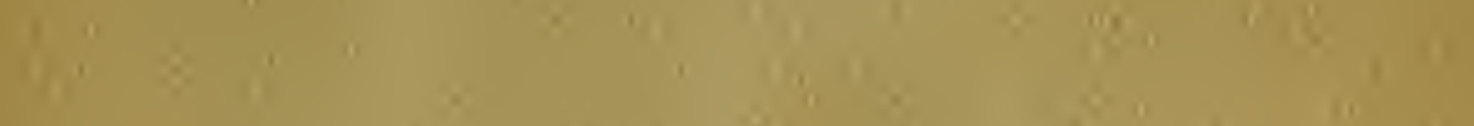

(1)

(1)

(1)

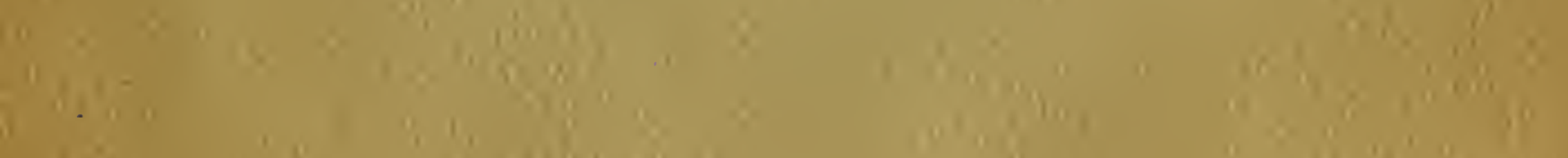

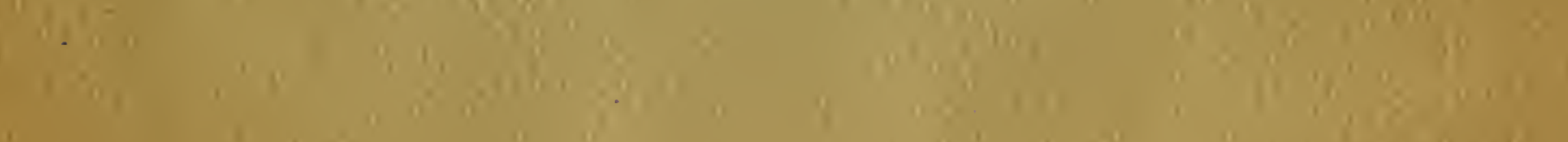
W.t.

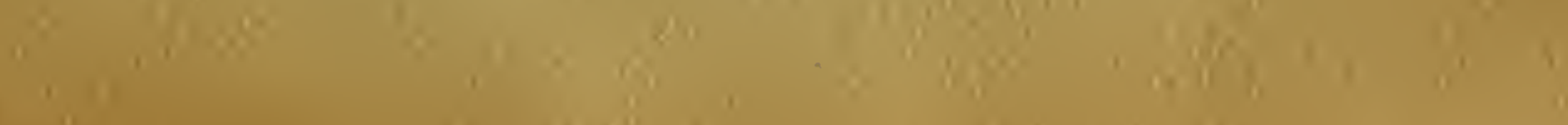

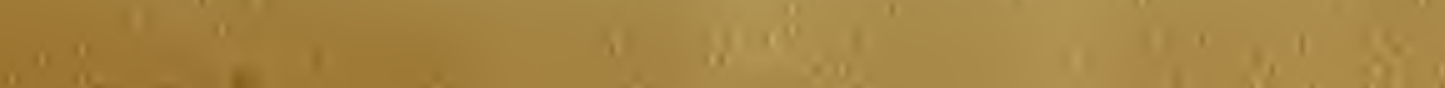








